\title{
Social Power and the Turkish State
}

\author{
Tim Jacoby
}

Doctor of Philosophy

The University of York

Department of Politics 


\begin{abstract}
The thesis focuses on the historical sociology of the Turkish state. It seeks to compare the development of the Ottoman/Turkish state with similar processes of large-scale historical change in Europe identified by Michael Mann in his two-volume text The Sources of Social Power. In these and in a series of shorter works, he develops an historiographic model based on four overlapping power networks (political, ideological, economic and military). Having spent the first two chapters giving an account of Mann's analysis and locating it with the spectrum of approaches to the study of the state as a sociohistorical phenomenon, the thesis relates each of these networks to developmental patterns apparent in Turkey before concluding with an explication of the main areas of continuity and change and a critical consideration of Mann's rubric.
\end{abstract}




\section{Acknowledgement}

This thesis has been prepared under the auspices and supervision of Professor Alex Callinicos. It is based, in part, on the time I spent living and working in Aydnn in Turkey in 1993 and 1994 and on later visits in 1998 and 2001. I am grateful to all the staff at the Department of Politics at York for supporting my work during the last two and a half years. In particular, I would like to thank Alex for his patience, guidance and advice. I would also like to thank my father for prouf reeding this thesis and, with my mother, for currently paying most of our bills. The biggest vote of thanks, though, must go to my wife, Jane, and our children, Idris and Iman. Since coming to York, they have lived in the shadow of this thesis and should thus receive much of whatever credit it deserves. 
In Memory of Helen Jacoby 


\section{Table of Contents}

Abstract

Acknowledgements

List of Illustrations vi vi

Introduction 1

Chapter One $\quad 5$

Power, The State and Turkey

Chapter Two 49

Mann's Brief History of Time

Chapter Three

The Politics of Empire

Chapter Four

The Ideology of Modernism

The Economics of Liberalisation

Chapter Six

The Military/Industrial Complex

Conclusion

Bibliograpby 


\section{List of Illustrations}

\begin{tabular}{|c|c|c|}
\hline \multicolumn{3}{|l|}{ Tables } \\
\hline One: & Two Dimensions of State Power & 22 \\
\hline Two: & Askeri 1545-1659 & 104 \\
\hline Three: & The Contradictions of Imperial Rule & 126 \\
\hline Four: & $\begin{array}{l}\text { The Tracklaying Achievements of } \\
\text { Ideological Power }\end{array}$ & 136 \\
\hline Five: & $\begin{array}{l}\text { The Media of Commercial Statist } \\
\text { Proto-Nationalism }\end{array}$ & 141 \\
\hline Six: & $\begin{array}{l}\text { Parliamentary Deputies Representing } \\
\text { Various Ottoman Communities }\end{array}$ & 154 \\
\hline Seven: & Birthplaces of Military and Civilian Leaders & 163 \\
\hline Eight: & A Selection of Reforms 1922-1935 & 165 \\
\hline Nine: & $\begin{array}{l}\text { The Birthplace of Political and } \\
\text { Bureaucratic Elites }\end{array}$ & 193 \\
\hline Ten: & $\begin{array}{l}\text { Numbers of Selected Farm Machinery } \\
1948-1954\end{array}$ & 6 \\
\hline Eleven: & Urban and Rural Populations & 197 \\
\hline Twelve: & Urbanisation by $R$ & 201 \\
\hline Thirteen: & Governance in the $1970 \mathrm{~s}$ & 237 \\
\hline Fourteen: & $\begin{array}{l}\text { Civilian, PKK and Security Force } \\
\text { Causalities 1984-1995 }\end{array}$ & 251 \\
\hline \multicolumn{3}{|l|}{ Figures } \\
\hline One: & The Four Dimensions of Social Power & 51 \\
\hline Two: & Strategies of Imperial Domination & 60 \\
\hline Three: & $\begin{array}{l}\text { Changes in Ottoman Ideological Channels } \\
\text { of Communication }\end{array}$ & 129 \\
\hline Four: & $\begin{array}{l}\text { Changes in Ottoman Compulsory } \\
\text { Co-operation }\end{array}$ & 130 \\
\hline Five: & $\begin{array}{l}\text { The Position of the National Security } \\
\text { Council in Turkey's State Security Structure }\end{array}$ & 247 \\
\hline Six: & $\begin{array}{l}\text { Large-Scale Change in the Development of } \\
\text { The Ottoman/Turkish State }\end{array}$ & 263 \\
\hline
\end{tabular}




\section{Introduction}

This study looks closely at how the method of governance apparent in Turkey came into being by applying, and expanding upon, the historical and comparative sociological theory of Michael Mann. In doing so, the Turkish government's relations with dominant groups in civil society, the nature and extent of its autonomy and its changing approach to representation and sovereignty are examined in historical perspective. This illuminates questions of constitutional and social reform, the re-distributive role of the state and the changing centreperiphery balance with particular reference to the devolution of centralised powers. The study sets out the changing way in which Turkish governance has represented the interests of, and arbitrated between, various elements of the civil elite, its development of independent regulatory regimes, both economic and judicial, and its search for greater democratic accountability. Mann's conceptual model of the sources of social power is used to analyse the differing ways that these have been institutionalised in Turkey and how state power has been organised in relation to economic and civil networks and associations

The first chapter aims to offer an impression of the vast amount of academic material informing the current debate over social power and the role of the state. Within the opening section, Michael Mann's work will be considered in relation to these different approaches and the focus of this thesis positioned therein. The second part of the chapter will then give an account of the historical development of the Ottoman/Turkish state based on the wide range of analyses available. A number of issues and questions arising from both the theoretical and historical material will then be put forward. These will be addressed in the succeeding chapters.

Chapter Two aims to give an account of Michael Mann's application of his theoretical model. In doing so, it will show how his largely 
abstract characterisation of social power is employed to explain both the emergence and necessity of the state and the permutable nature of its relationship with civil society. A central element of this is the essentially unilinear thread that Mann traces from Mesopotamian development to the refinement of imperial rule under Rome and its eventual subsidence in favour of the north-western European "leading edge' of socio-economic change during the medieval period and on to the appearance of modern bureaucratic nation-state. These key periods of power development make up the primary framework through which Mann's theoretical composition is applied. Having set out this model and broadly outlined the historiographic line which Mann traces, the final section of this chapter will then highlight the critical debate that has surrounded his work since the publication of the first volume of The Sources of Social Power in 1986.

Chapter Three deploys Mann's reworking of Herbert Spencer's model of 'compulsory co-operation' to illuminate the large-scale political changes that became apparent in the Ottoman Empire following its failure to expand during and after the sixteenth century. I argue that while this system was initially highly effective, representing in many ways a much more sophisticated method of imperial rule than the Roman legionary economy discussed by Mann, it was unable to function effectively during territorial contraction. In Chapter Four, the ideological impact of this is traced with a particular focus on the role of the ulema. Here I argue that the intrinsically multi-national orientation of the theocracy was at odds with the centrist modernism of the 'Turkish' state elite - a quite different process from the Western European nation-state/Church relationship presented by Mann.

Chapter Five outlines the tussle for power in Turkey between the state bureaucracy and the capitalist classes (represented by the Menderes government of the 1950s) and compares it to Mann's account of the emergence of class-consciousness in Western Europe. 
Chapter Six continues this theme by looking at the role of the military in Turkey since the 1960 coup. It argues that during this period the interests of the bourgeoisie and those of the military began to conflate. The effects that this had on the levels of domestic repression and geopolitical militarism in Turkey are compared to Mann's regime categories with particular reference to the conflict in south-east Anatolia. The concluding chapter then reiterates and ties together the main points of the narrative by retracing each of the four power networks in Turkey and reflecting upon the validity of Mann's model.

By re-examining Mann's model for adequacy and fruitfulness in light of Turkish social development, the thesis also makes methodological progress. It considers extensions and adaptations of Mann's work as a means of understanding governance and social power more generally and explores the basis and development of Turkish state power as well as connected social phenomena such as territoriality, accountability, nationalism and secularism. In deploying Mann's analysis of four irreducible networks of social power to a nonWestern case study, their inherent and varying capabilities to instigate social institutions can be critically approached. In this way, the thesis assesses the extent to which Mann's four-part rubric constitutes a viable means of considering elite behaviour and illuminating alternative organisational means of social control. While the study concludes that this framework is indeed a useful tool in the analysis of large-scale social change, numerous revisions and counterpoints are highlighted. As such, each network's organisational significance is clarified in light of its application from power-holder to powersubject and the social space in which each has been contested. In doing so, an historical account of the autonomous power of the Turkish state is narrated which uses Mann's sociological position and thus gives a clearer understanding of both.

In all, the study analyses the process of state-building which has occurred in Turkey from the changes developed during the Ottoman 
Empire to the organisation of the modern day government. It focuses on issues concerning the state's relationship with civil society, particularly those that arise from the way in which governance and the state is conceived by both the Turkish majority and non-Turkish minorities. It looks at the peculiarities of Turkey's process of modernisation and democratisation with the intention of furthering our understanding of state-development in countries on the global economic periphery, particularly those attempting to effect closer relations with Northern markets. It also highlights issues of social changes pertinent to states grappling with the issues surrounding secularisation and political Islam and to states with substantial social minorities that are struggling for national unity amid irredentism and periods of instability. 


\section{Chapter One: Power, The State and Turkey}

Essentially this thesis proposes to develop an historical case study of the evolution of the state in Turkey by focusing on Michael Mann's construction of the nature and the distribution of social power. In considering power and its distribution there are three broad schools of thought; the elitist, the Marxist and the pluralist. Given the lack of agreed definitions and parameters, categorical positions are few and much of the research overlaps. The first part of this chapter therefore aims to offer only an impression of the vast amount of academic material informing the current debate over social power and the role of the state. Michael Mann's work will be considered in relation to these different approaches and the focus of this thesis positioned therein. The second part of the chapter will give an account of the historical development of the Ottoman/Turkish state through the nineteenth and twentieth centuries based on the wide range of analysis available. A number of issues and questions arising from both the theoretical and historical material will then be put forward. These will be addressed in the succeeding chapters.

\section{Theories of Social Power}

Fundamental to the existing literature are the basic theoretical questions: who exercises political power; how is it exercised; and to what end is it exercised? Further to these are: to what extent is power centralised or diffused in social groups; and to what extent does it operate hierarchically? Elite theorists argue that an identifiable social group within a given collective exercises power based on rational, value-maximising self-interest. In part, this was a response to the Marxist analytical framework which holds that an historically specific economic class maintains political power by controlling the means of production. Pluralism emerged predominantly during the 1960 s as a reworking of the liberal internationalism of the early 1920s with 
theorists such as Robert Dahl and David Mitrany arguing that power is not concentrated in the hands of any particular group, but dispersed, varying from issue to issue, throughout society. ${ }^{1}$

In his study of the decision-making process in New Haven, Dahl argued that access to power is dependent on the matter to be decided upon. He distinguishes between 'social' and 'economic' notables and the holders of political office, describing the structure as a "polyarchy". ${ }^{2}$ He constructs the state as an arena in which competing elites (within their own decision-making spheres) negotiate over different options and where a virtual consensus exists about the arrangement of political structures and opportunities for representation. Evidence for this was cited in the success of interest groups in the American political system and criticism of the theory initially centred around its transferability - particularly after much of New Haven was subsequently affected by civil unrest. ${ }^{3}$ Bachrach and Baratz continued the critique by arguing that pluralists, in focusing only on what was contained within the political agenda and not access to agenda-setting mechanisms, were ignoring wider aspects of contention. ${ }^{4} \mathrm{~A}$ third criticism, prevalent in Marxist discourse, was based on the idea of a 'false consciousness' in which individuals, made unaware of their interests by the structure of power into which they are unwittingly embedded, mistakenly adopt a course of political inactivity. ${ }^{5}$

Integral to this notion is the distinction between subjective interests, what individuals believe that they want, and objective interests, what individuals would chose if they were fully aware of all the options available. This, in keeping with much of the general Marxist position, takes power as a given, implicit as it is in the concept of a ruling or dominant class. Writers such as Antonio Gramsci have tended to

\footnotetext{
${ }^{1}$ Dahl, R. A. (1961) passim. Mitrany, D. (1966) passim.

${ }^{2}$ Dahl, R. A. (1961) passim.

${ }^{3}$ For example, Presthus, R. (1964) passim.

4 Bachrach, P. \& Baratz M. (1962) passim.

'Exemplified by Lukes' (1974) identification of this as "the third dimension of power" passim.
} 
conceive of an elite's position as less determined by force than by an hegemonic ability to represent its own interests as that of society's. ${ }^{6}$ In other words, or as the structuralist argument of Nicos Poulantzas puts it, power is "the capacity of a social class to realise its specific objective interests". As such, values and norms, for analysts like Louis Althusser, become embedded in the ideological apparatus of the state and, through socialisation, lead to the evolution of peculiar political cultures. ${ }^{8}$

The economic elitist approach, particularly James Burnham's, comes very close to this construction of society. ${ }^{9}$ It accepts that the control of the means of production is vital to the maintenance of the powerholder's position, but predicts that this is likely to strengthen as the managerial elite continues to centralise bureaucratic controls. This is built on the work of earlier elite theorists, such as Michels and Mosca, who emphasised the importance of organisation in exercising power over the less organised. The former looked at power structures in the German Social Democratic Party and concluded that social organisation inevitably leads to oligarchic rule and the development of an apathetic majority. ${ }^{10}$ For Mosca, an elite consists of a small group of decision-makers who manipulate society for its own good, supported by a larger pool of more compartmentalised leaders who supply personnel for the higher echelon. Authority may flow from this dichotomy to the masses, as in the autocratic ideal type, or from the masses towards the elite within a liberal polity - or, more commonly, both act simultaneously. ${ }^{11}$ Pareto concurs with Mosca in his identification of the dual nature of the elite, describing them as governing and non-governing, but goes on to argue that it is not socioeconomic forces that determine this structure. Rather, it is the inherent characteristics of the human psyche. He proposes that individuals tend

\footnotetext{
${ }^{6}$ Gramsci, A. (1971) passim.

${ }^{7}$ Poulantzas, N. (1973) p. 104.

${ }^{8}$ Althusser, L. (1977) passim.

9 Burnham, J. (1942) passim.

${ }^{10}$ Michels, R. (1911) p. 418.

${ }^{11}$ Mosca, G. (1939) passim.
} 
to conform to one of two classes (manipulative foxes or over-bearing lions) and that, rather than adhering to a common direction, the elite is internally divided through constant conflict and competition. ${ }^{12}$

In C. Wright Mills' institutional model of social power, conflict also exists between elements of the ruling elite. At the top level of his threetier structure those in command of institutional hierarchies exercise a considerable degree of autonomy within their political, military and economic spheres of influence. The middle level is where the pluralist model of competing interests applies and the bottom level consists of the politically disparate masses. Despite acknowledging the increasing influence of economically-determined interests in political processes, Wright Mills argued that it is mistaken "to believe that the political apparatus is merely an extension of the corporate world, or that it has been taken over by the by the representatives of the corporate rich". ${ }^{13}$ This, too, is the position of statist elite theories for whom the state is held to be an autonomous actor operating independently of the dominant elements of civil society. By highlighting "instances in which non-constitutionally ruling officials attempt to use the state as a whole to direct and restructure society and politics"14 this "relatively recent discursive development has represented a far more cogent challenge to pluralism than its predecessors". ${ }^{15}$ It is this theoretical area, particularly the work of Michael Mann as one of the foremost exponents of the statist argument, which will form the focus of the following section.

\section{Michael Mann's Theory of Social Power}

Bertrand Russell put forward the idea that just as energy is the fundamental concept of physics, so power is the fundamental concept of the social sciences. Like physical energy, he argued, social power comes in many forms of which none is supreme nor derivative of

${ }^{12}$ Pareto, (1916) Vol. IV pp 2178-2275.

${ }^{13}$ Mills, C. W. (1956) p. 170.

${ }^{14}$ Skocpol, T. (1985) p. 11.

${ }^{15}$ Evans, M. (1994) p. 26. 
another. Regarding one as ultimately determinant, such as the Marxist emphasis on economic dynamics or the nineteenth century military historical rubric, can, he suggested, only generate partial accounts of social phenomena. Instead, social power, like its physical counterpart, should be regarded as continually moving from one form to another, the interaction of which structure all social inter-relations. ${ }^{16}$

This is also the starting point for Michael Mann who treats the organisation of social power as the primary motor of history. Accordingly, it is mistaken to assume that conformity is solely the result of an internalisation of the norms of society. Human beings, Mann suggests, interact according to socio-spatial spheres, based not on the shared values of a unitary society or nation-state, but on agreed or conflicting goals within overlapping power networks. As people seek sexual fulfilment families emerge which then interact with other families from which partners may be found and so on. These families may also develop economic relationships which may overlap with existing family or sexual relations, but are unlikely to be identical. Similarly as they defend their property or take others' they may form armed organisations which require relations with non-combatants in order to ensure supplies. They may also organise a judiciary to settle disputes without resorting to arms or seek meaning in shared rituals of worship. For Mann, there is no reason to presume that these social requirements should produce the same patterns of interaction and therefore a unitary society; "Human beings need to enter into social power relations, but they do not need social totalities. They are social, not societal, animals". ${ }^{17}$

Russell identified these relations as taking the form of "wealth, armaments, civil authority, influence on opinion" which, he continues, are essentially quantitative in character. ${ }^{18}$ For example, if $A$ possesses more wealth, armaments, civil authority or influence on opinion than

\footnotetext{
${ }^{16}$ Russell, B. (1938) passim.

${ }^{17}$ Mann, M. (1986) p. 14.

${ }^{18}$ Russell, B. (1938) pp 10-11.
} 
$B$, then $A$ will be able to achieve goals that $B$ will not; so $A$ can be said to be more 'powerful' than B. ${ }^{19}$ Mann starts from a similar point identifying the "sources" of power as ideological, economic, military and political and describing them as "overlapping networks of social interaction". ${ }^{20}$ For Mann, though, these are not simply quantitative measures of an actor's capability, but the arena of all human interaction which, when organised into social institutions, become generalised means of achieving goals and therefore sought for their own sake.

He suggests that, "Their primacy comes not from the strength of human desires for ideological, economic, military or political satisfaction, but from the particular organisational means each possesses to attain human goals, whatever these may be". ${ }^{21}$ Social power can therefore be considered in terms of its organisational capacity to create and maintain social institutions and it is this tendency that has led to the illusion of a unitary society. As human interaction has developed, institutionalisation also developed as, what Mann describes as, an emergent need in order to monitor production and transaction, to standardise rituals of worship, regulate conflict and so on. It is thus the extent to which the institutionalisation of these interrelations overlap with each other that determines conformity and produces the appearance of a unitary society. ${ }^{22}$ Mann points out, however, that since these institutions are further removed from human needs than the power networks themselves, goal-directed behaviour often runs contrary to, or seeks to establish alternatives to, the prevailing organisational arrangements. This can be unintentional or, in the case of value conflicts, a direct challenge..$^{23}$

\footnotetext{
${ }^{19}$ Ibid. p. 35.

${ }^{20}$ Mann, M. (1986) p. 2.

${ }^{21}$ Ibid.

${ }^{22}$ The internalisation of the norms of 'society' is simply an effect of this primary dynamic and does not contribute, in itself, to the development of shared goals.

${ }^{23} \mathrm{~A}$ conflict of value can be distinguished from other less fundamental forms of conflict and is defined by Chris Mitchell as where "parties differ fundamentally about the nature of desirable end states or social and political structures" (1981) p. 37.
} 
For Mann, the process of institutionalisation can occur through conflict or co-operation. The former, he describes as essentially distributive in that for one actor to gain the other must lose. ${ }^{24}$ The latter, he describes as collective. Talcott Parsons identified this as primarily a means of achieving social goals, whereby actors employ their joint power over other actors or nature, such as within a polity. ${ }^{25}$ In Dennis Wrong's view, though, most institutions are not instigated by one or the other aspect of social power, but by a combination of the two. He writes;

"Only the most doctrinaire anarchist or proponent of direct democracy would maintain that authorising some men to authorise the activities of others is so corrupting and conflict-producing for all concerned that it should never be considered as a means of achieving collective goals. And only the most naive believer in the malleability of men, in their almost infinite capacity to be socialised to serve larger collective ends in a heterogeneous society in which many resources are unequally distributed, would deny that power is peculiarly susceptible to being diverted into use for self-interested purposes by individuals and groups". ${ }^{26}$

Mann agrees, regarding the institutionalised division of labour, for instance, as a clear example of collective power organisation with specialised functions at all levels. Simultaneously, though, it also maintains a minority in organisational control of the implementation of collective goals and ensures, by enshrining their supervisory positions in the norms of the social group, that there is not the necessary organisational means for the majority, free to rebel though they are, to implement those goals themselves. Thus, "the masses comply because they lack collective organisation to do otherwise, because they are embedded in collective and distributive power organisations controlled by others". ${ }^{27}$

\footnotetext{
${ }^{24} \mathrm{Max}$ Weber defined this process as "the probability that one actor within a social relationship will be in a position to carry out his will despite resistance" (1968, p. 53).

${ }^{25}$ Parsons, T. (1958) pp 207-208.

${ }^{26}$ Wrong, D. H. (1979) p. 247.

${ }^{27}$ Mann, M. (1986) p. 7.
} 
In order to compare various power interrelations Bertrand de Jouvenel distinguishes three general attributes of the overall distributive/collective dialectic which distinguish separable aspects of compliance or, what he describes as "an efficient imperative". ${ }^{28}$ Power, he argues, "is extensive if the complying Bs [power subjects] are many; it is comprebensive if the variety of actions to which A [power holder] can move the Bs is considerable; finally it is intensive if the bidding of A can be pushed far without loss of compliance". 29 Mann, however, while accepting and extending de Jouvenel's work, identifies two facets of this comprehensive power relationship. It may be authoritative if deliberate and consciously applied by groups or individuals or diffused if more spontaneous and de-centred "resulting in similar social practices that embody power relations, but are not explicitly commanded... [and based on] an understanding that these practices are natural or moral or result from self-evident common interest". ${ }^{30}$ Each, he notes, may be applied in a collective or a distributive manner, or, more commonly, a blend of both.

Robert Dahl similarly builds on the notion of comprehensiveness which, he suggests, refers to the number of scopes, or choice areas, that is subject to control. ${ }^{31} \mathrm{He}$ concluded that only in extreme cases of dependence, such as the almost completely comprehensive control of parent over infant, could a power-holder expect to be influential across numerous scopes. More usual, Dahl suggests, is power exercised within highly specialised roles, such as aircraft controllers or university lecturers, where power-holders could not expect to be influential over their subjects outside the boundaries of their legitimised field. Thus the intensity of a relationship can be considered to be the range of options available to a power-holder within a given scope. This, as de Jouvenel points out, is self limiting as there will always be a point, variable

\footnotetext{
${ }^{28}$ De Jouvenel, B. (1958) p. 160.

${ }^{29}$ Ibid. My parentheses.

${ }^{30}$ Mann, M. (1986) p. 8. My parenthesis.

${ }^{31}$ Dahl, R. A. (1963) p. 46.
} 
according to the nature of the structure and the power-subjects, where compliance breaks down. ${ }^{32}$

Comprehensive and extensive power is, as Dennis Wrong, notes, also limited. ${ }^{33}$ This is often in the form of statutory constraints upon powerholders aimed at excluding their influence from certain scopes, such as assembly, worship and expression, and restraining it within others, such as the ban on the 'closed shop' in organised labour movements or the regulations imposed on magistrates when sentencing. The extensiveness of a power relationship, he argues, may, according to the number of hands sovereignty is held by, range from kingship to oligarchy to democracy and is best considered as "the ratio of the number of persons who hold power to the number of the powerless". ${ }^{34}$ Wrong also notes that a fundamental problem for power-holders is that as the extensiveness of their power increases, comprehensiveness and intensity tends to decrease. This, he argues, is for three main reasons; firstly, the more power-subjects the more supervision becomes problematic. Secondly, the more power-subjects the more links in the chain of command needed to control them and the more the risk of an organised challenge, and thirdly, the more power-subjects the wider the variation of attitudes to the power-holder..$^{35}$

In Robert David Sack's analysis, power-holders can reduce the decentralising effects of expansion by reinforcing territorial uses of space. This can be employed to circumscribe access to knowledge and responsibility, monitor the "span of control" or level of supervision and convey possession, exclusion or simply the visibility of power itself. Moreover, territoriality's classificatory emphasis on area rather than type can be used to conceal the social nature of the relationship between power-holder and subject or exert a diffused comprehensive influence. As Sack points out, territoriality may also increase the rigidity

\footnotetext{
${ }^{32}$ De Jouvenel, B. (1958) p. 160.

${ }^{33}$ Wrong, D. H. (1979) p. 16.

${ }^{34}$ Ibid. p. 15.

${ }^{35}$ Ibid. p. 20.
} 
of a social hierarchy and the value of a centralised bureaucracy by "helping to enforce differential access to things... [which] become institutionalised in rank, privilege and class... [and] by being used as a general means of dividing and conquering". ${ }^{36}$ In occupying and designating space, an educational institution, for instance, tends to reinforce the position of teachers over taught. Classrooms, offices, common rooms, car parks and so on are all designed to facilitate the supervisory role of the organised minority over the unorganised majority. As "the means by which space and society are interrelated" and "the attempt by an individual or group to affect, influence or control people, phenomena, and relationships by delimiting and asserting control over a geographic area", territoriality may be regarded as an important conceptual link between the organisation of social power and the autonomy of state action. ${ }^{37}$

\section{Mann and Macro-Historical Sociology}

Since the publication of Barrington Moore's The Social Origins of Democray and Dictatorship in 1966, there has been a revival in what may be called the 'macro-historical' sociology of Durkheim, Marx and Weber. In the United Kingdom, this has been particularly apparent during the last fifteen or so years. Writers such as John Hall (Powers and Liberties, 1985) and Anthony Giddens (The Nation-State and Violence, 1985) have turned to the analysis of large-scale historical transformations in order to better understand the character of contemporary social phenomena such as stratification, nationalism and statehood. This section aims to locate Mann's work within the discipline of macro-historical sociology by critically outlining a range of approaches broadly encompassed by the term macro-historical sociology.

\footnotetext{
${ }^{36}$ Sack, R. D. (1986) p. 39. My parentheses.

${ }^{37}$ Ibid. p. 5 \& p. 19.
} 
Macro-historical sociology can be considered to have been born of three intertwined objectives;

"An bistorical-causal analysis of origins considers the conditions which give rise to modern institutions relevant to understanding their present nature and likely persistence... A quest for variation seeks to understand modern institutions like capitalism or the nation-state or particularly by comparing them with social groups with other types of economic, political or gender institutions... A more abstract-comparative macro-sociology, less tied to understanding the present, analyses the past to test more general propositions about human communities". ${ }^{38}$

These three components have structured the current body of macrohistorical literature. The first relates to the linearity of the narrative. In other words, the extent to which elements of the historiography link together to form a discernible whole. The second relates to the narrative's laterality, or the breadth of social phenomena encompassed and compared. The third relates to the epistemological consistency of the narrative, or the certainty with which claims regarding the past's relationship with the present are advanced.

Of the spectrum of approaches which have appeared in pursuit of these objectives, Theda Skocpol's and Barrington Moore's represent arguably the most firmly comparative. Both attempt to use J S Mill's methods of agreement and difference as their primary research tool. In the Social Origins of Dictatorship and Democracy, Moore identifies three alternative routes to modernity and seeks to explain areas of similarity and contrast through comparison. As Skocpol has pointed out, within these routes Moore primarily relies on establishing causal commonalties. ${ }^{39}$ Across the three routes, however, he focuses on their contrasting developmental patterns to help validate each. The

\footnotetext{
${ }^{38}$ Mann, M. (1994) p. 39.

${ }^{39}$ Skocpol, T. (1994) pp 79-80.
} 
conclusion reached is that 'modern' states can be categorised as having followed 'communist', 'capitalist-reactionary' or 'bourgeois' courses of development. Skocpol also employs a combination of Mill's approaches. In States and Social Revolutions, she argues that Bourbon France, late imperial China and Tsarist Russia all possessed some similar causal features while introducing negative cases from Britain, Japan and Germany to strengthen her assertions of shared specificity. Her conclusion is that the causes of the Chinese, French and Russian revolutions can be reduced to two components: political crisis and peasant revolt.

For Skocpol, then, causal explanations are inferred from existent historical data through a Millian process of induction. How, she asks, "are we ever to arrive at new theoretical insights if we do not let historical patterns speak to us, rather than always viewing them through the blinders, or heavily tinted lenses, of pre-existing theories"? ${ }^{40}$ Is this tenable, though? Surely some theoretical endeavour is necessary in order to select the cases to include. The result of this reluctance to offer an explicit historiographic model is that method tends to replace theory ${ }^{41}$ Consequently, Skocpol is able to describe the factors that lead to revolutions, but she cannot explain their causes. ${ }^{42}$ Moore, on the other hand, is more frank about his ideological perspective. Writing within the Marxist tradition, his narrative is simultaneously moralising and analytical. While his emphasis on economic determinacy strengthens his construction of causality, his arbitrary rejection of cultural factors as possible explanations of his cases' progress along their allotted routes significantly damages his claims of generality. ${ }^{43}$ Furthermore, neither the criterion for selecting cases nor the basis upon which his moral cost/benefit analysis proceeds are elucidated with sufficient clarity. ${ }^{44}$ Why, for instance, is much of Africa, parts of Asia and the almost the whole of the Middle-East excluded? The reader is left to conclude that

\footnotetext{
${ }^{40}$ Skocpol, T. (1986) p. 190.

${ }^{41}$ Burawoy, M. (1986) p. 769.

${ }^{12}$ Stinchcombe, J. (1983) pp 12-15.

${ }^{43}$ Rothman, S. (1970) pp 61-64.

${ }^{44}$ Smith, D. (1984) pp 168-169.
} 
countries have been chosen simply on the grounds of which best concur with the pre-existent determining features of each route. In the case of both Moore and Skocpol, then, their reluctance to establish a theoretical position which explains precisely why cases were either selected or ignored appreciably impairs what Mann terms the abstractcomparative facet of their macro-social inquiry.

By contrast, W G Runciman's three-volume Treatise on Social Theory (1983, 1989 and 1997) combines both an explicit theory of social interaction - drawn from Weber's tripartite classification of power as class, status and party - and an encyclopaedic sweep of global history. As such, this taxonomy of societal change is underpinned by irreducible networks of economic, ideological and political power organised as a means of 'domination' or co-operation'. In this sense, Runciman's model represents, on the one hand, an attempt to form a bridge between Marxian notions of economic primacy and a more comprehensive theorisation of social power and, on the other, a middle road between elitist and pluralist conceptions of political organisation. It is, in fact, a reworking of Skocpol's "reified collective wills". ${ }^{45}$ Rather than acting on behalf of the dominant economic group in civil society, state elites, for Skocpol, behave as arbiters of a structure determined by organised coercion. Drawing upon Otto Hintze's two-dimensional view of state organisation, ${ }^{46}$ she argues that this may either be in order to secure their position in relation to other states or to domestic society from which resources are coercively extracted ${ }^{47}$ These views are opposed to Moore's contention that the evolution of states towards either the liberal or the authoritarian model can be explained in terms of the kinds of relationships that landed upper classes make with the commercial and industrial bourgeoisie. Instead the state is seen as an autonomous player capable of acting either in, or against, the interests of dominant groups within civil society.

\footnotetext{
${ }^{45}$ Skocpol, T. (1994) p. 8.

${ }^{46}$ Hintze, O. (1975) p. 183.

${ }^{47}$ See Skocpol, T. (1979) pp 29-31.
} 
Runciman's application of this schema is, however, deficient in two ways. ${ }^{48}$ Firstly, the 'co-operative' organisation of social power makes few appearances in his narrative outside its function as a means of collectively increasing a society's capacity to dominate nature. Little mention is made of its role in the construction of collective social identities. Secondly, ideological power is given only a minimal part outside its use as a way of instilling deference. To identify the power of world religions as primarily grounded on the authority of clerics is not plausible and undermines Runciman's commitment to generality. Indeed, the discrepancy between theoretical potentiality and empirical restriction becomes more apparent in his conclusion that, despite having identified over 450 possible kinds of society, history has, he concludes, only produced ten. His failure to explain precisely why this has proven to be the case means that his theoretical typology lacks an historiographic dynamic. ${ }^{49}$ While he ostensibly avoids the threat to causal coherence that this weakness entails by a retreat from claims of 'explanation' to 'description, ${ }^{50}$ his concession to socio-biological evolutionism only exacerbates the disjuncture between theory and data. Since his neo-Darwinian motif of 'selection' as the motor which underpins social change is left unexplained and unconnected to his broader theorisation of power, the elucidation of historical cases appears to be isolated and 'pointillist'.

More firmly evolutionist writers are, on the other hand, less burdened with the demands of comparativism. Favouring greater methodological linearity, they generally proceed on the basis that the evolution of human life can be quantified as moving towards ever-greater complexity and differentiation. In this way, 'directional laws' are elaborated in which historical transformations occur as a result of inherent potentialities. ${ }^{51}$ In epistemological, or abstract-comparative, terms change is held to be universally immanent, necessary and

\footnotetext{
${ }^{48}$ Anderson, P. (1992) pp 152-153.

${ }^{49}$ Anderson, P. (1992a) p. 223.

${ }^{50}$ Runciman, W. G. (1983) p. 41.

${ }^{51}$ See Mandelbaum, M. (1971) passim.
} 
embedded in the generic processes of nature. ${ }^{52}$ Thus a narrative emerges in which biological linear causality is adopted as mechanistic means of explaining human history..$^{53}$ It is clear, for example, that Talcott Parsons based his later accounts of societal development on the teleological premise that evolution occurs in order to produce a pattern of advancement based assessed by a biological criterion. In 1966, he wrote that "intermediate societies are more advanced than primitive societies and modern societies... are more advanced than intermediate societies" where 'advanced' means those "systems that display greater generalised adaptive capacity". ${ }^{54}$ Lenski offers a comparably grounded narrative in which technological progression is the prime motor of human advance. ${ }^{55}$ As with Parsons' 'differentiation', however, no basis, outside the process of change itself, is suggested as a means of evaluating the impact of the evolutionary developments which he is describing. The result in both cases is an arbitrary and ethnocentric conclusion that modernity contains improvements over the past.

For some evolutionists, though, presenting scientific generalities need not produce a narrative which assumes progression. Stephen Sanderson, for instance, rejects Parsons' tendency to analyse past events not "for their own sake, but only in terms of their ultimate contribution to modernity" concluding that "word-historical transformations, whether parallel, convergent, or divergent evolution, are not the unfolding of predetermined patterns. ...Instead they represent the grand aggregation and multiplication of the actions of individuals and groups... responding to a multiplicity of biological, psychological and social needs". ${ }^{56}$ As such, his narrative, entitled 'evolutionary materialism', abandons the conflation of 'change' and 'advance' and concedes that "it cannot automatically be assumed that later social forms will be associated with higher levels of human

\footnotetext{
52 See Nisbet, R. (1969) passim.

${ }^{53}$ See Giddens, A. (1984) pp 231-233.

${ }^{54}$ Parsons, T. (1966) pp 109-110.

${ }^{55}$ See Lenski, G. (1970) passim.

${ }^{56}$ Sanderson, S. (1992) p. 118 \& (1995) p. 5.
} 
adaptedness". ${ }^{57} \mathrm{He}$ also modifies Lenski's and Parsons scientism by dismissing many key elements of the biological method. Such caution means, however, that his narrative both lacks theoretical coherence and an explicit means of joining the past with the present. ${ }^{58}$ As a consequence, Sanderson's explanatory power is significantly reduced.

In the introduction to the first of his two volumes of The Sources of Social Power, Michael Mann claims to take a middle path between evolutionary narrativism and the problematic laterality of Skcopol, Moore and Runciman. His narrative incorporates a comparative and a linear component pre-structured by a complex theoretical consideration of social power which also claims to represent a compromise; this time between materialist and idealist understandings of the past. His composition is built around key periods of power development based on overlapping networks of political, military, ideological and economic interaction. As the primary organisational form of political power in society, the state has the leading role in this narrative. Since political power networks are distinguishable by their centralised location and their tendency, in both domestic and geopolitical terms, to reinforce rather than transcend territorial boundaries distinguishes states possess "an independence from civil society which, though not absolute, is no less absolute in principle than the power of any other major group". 59 Economic power groupings are likely to be more diffused and decentred. They tend to operate in competition with other groupings in any given territorial delimitation. Ideological power movements are similarly "interstitial" often crossing state boundaries and stressing the artificial and ephemeral nature of such divides. Although Mann concedes that military power, is more analogous to the state's monopoly of organised violence over its territory than other more clearly separable networks of social power, he resists Weber's reduction of military and political power into "party". He suggests that states with limited infra-structural reach were rarely able to claim such a

\footnotetext{
${ }^{57}$ Sanderson, S. (1995) p. 397.

${ }^{58}$ Ibid. p. 381.

${ }^{59}$ Mann, M. (1984) p. 200.
} 
monopoly, that militarily organised social groups are often institutionally separate from the state and quite capable of acting independently of it and that, in the international arena, political influence is, such as in the cases of modern Germany and Japan, not determined by military power. ${ }^{60}$

While he broadly concurs with Skocpol's assertion "that state organisations and elites might under certain circumstances act against the long-run economic interests of a dominant class", Mann seeks to forge a compromise between essentially pluralist accounts of state evolution and more structuralist perspectives. ${ }^{61} \mathrm{He}$ does so by combining two theoretical strands. The first is what he calls the "true elitist" argument. This holds that the state is a fully independent actor, invasive and ultimately concerned only with pursuing its own interests; ${ }^{62}$ Margaret Levi's 'predatory' theory of rule is an example. ${ }^{63}$ This form of analysis, Mann argues, is based more on 'distributive' power organisation and tends to emphasise war and sovereignty. The second strand is particularly prevalent in M. Weir et al's (including Skocpol) account of the restraining influence of American federalism on the power of the state. ${ }^{64}$ Here, the autonomous effects exerted by social institutions are emphasised in what Mann terms "institutional statism". He equates this with 'collective' power, arguing that "it affects more the forms in which politicised actors collaborate than who has power over whom".65

Thus, for Mann, the state, in organising the various networks of social interaction, on the one hand joins with other actors to employ their joint power over the polity or nature, and on the other, maintains itself in control of the implementation of these collective goals and ensures that there is not the necessary organisational means for the majority to

\footnotetext{
${ }^{60}$ Mann, M. (1986) pp 10-11.

${ }^{61}$ Skocpol, T. (1994) p. 37.

${ }^{62}$ Mann, M. (1993) p. 48.

${ }^{63}$ Levi, M. (1981) passim.

${ }^{64}$ Weir, M. et al. (1988) passim.

${ }^{65}$ Mann, M. (1993) p. 52
} 
rebel and implement their own goals. This application of social power as an imposition over, and as a means of facilitating co-operation through, state-bound territory corresponds to E. H. Carr's dialectical government of the people and over the people and is also strongly reminiscent of Runciman's dialectic of domination and co-operation. ${ }^{66}$ Or, put another way, it relates to an organised political elite's simultaneously collective and distributive capacity to instigate social change through networks of infra-structural and despotic state power. Despotic power concerns "the range of actions which the [state] elite is empowered to undertake without routine institutionalised negotiation with civil society groups". Infra-structural power, in contrast, "is the capacity of the state to actually penetrate civil society and to implement logistically political decisions throughout the realm". ${ }^{67}$ The way in which these have acted together in different ideal-types is shown in Table One.

Table One: Two Dimensions of State Power ${ }^{68}$

\begin{tabular}{|c|c|c|c|}
\hline \multirow{2}{*}{$\begin{array}{l}\text { Despotic } \\
\text { Power }\end{array}$} & Low & $\begin{array}{l}\text { Infra-structural Power } \\
\text { Low } \\
\text { Feudal }\end{array}$ & $\begin{array}{l}\text { High } \\
\text { [Liberal] Bureaucratic }\end{array}$ \\
\hline & High & Imperial & Authoritarian \\
\hline
\end{tabular}

In applying his theoretical model to the development of the European nation-state, Mann argues that feudal governments - reliant on the intensive, but non-comprehensive and non-extensive, might of the military and governing through an often autonomous sub-structure of clerics and burghers - tended to be low on both infra-structural and

\footnotetext{
${ }^{66}$ Carr, E. H. (1939) p. 96.

${ }^{67}$ Mann, M. (1984) pp 188-189, my parenthesis. He later expands upon this thus: "state infra-structural power derives from the social utility in any particular time and place of forms of territorial-centralisation which cannot be provided by civil society forces themselves... The extent of despotic power derives from the inability of civil society forces to control those forms of territorial centralisation, once set up" (ibid., pp 201-202). ${ }^{68}$ Adapted from ibid. p. 191.
} 
despotic power. ${ }^{69}$ Imperial states, by contrast, generally wielded high levels of often divinely legitimised despotic power through their own patrimonial government bodies, but, similarly constrained by the shortcomings of military force, had only a limited capacity to penetrate a frequently large and disparate territory and thus remained infrastructurally weak. The despotic power of modern bureaucratic democracies, on the other hand, is restricted within certain institutions such as the media, the market and the judiciary and thus usually have low despotic power. Through their information systems, however, they possess immense infra-structural power. Authoritarian regimes have similar levels of infra-structural reach, but are less encumbered by institutional restriction.

Mann's historical sociology of the state is thus, in essence, an attempt to account for these ideal-types. Arguing that, in order to understand centralised political power, one must focus on the evolution of the most powerful states, Mann concentrates on the specificity of modern European development. What is presented is an essentially linear thread from Mesopotamian and Roman imperial development to the appearance of modern bureaucratic nation-states. In attempting to forge a path which is, at heart, non-evolutionary as well as a rejection of the comparative method, Mann brings upon himself a number of methodological and textual difficulties. It is the aim of this thesis to resolve some of these problems by using the development of the Ottoman/Turkish state as a comparative case study. While the methodological implications of this are discussed more fully in the next chapter, here, in the following section, a brief synoptic sketch of the historical areas to be focussed upon in Chapters Three to Six. I will, in the vein of Mann's work, concentrate on particular areas of Turkish history which, in my view, were periods when major shifts in social power occurred. Below, then, is a survey of some of the common themes from the literature on Ottoman and Turkish political

\footnotetext{
${ }^{69}$ Outside the immediate area of contact, Mann argues that a civilian population alters its behaviour little (apart from to offer tribute and recognise a leader's suzerainty) in response to a military presence (Mann, M., 1986, passim).
} 
development. It identifies a range of key points and offers an indication of the topics, within the overall historical perspective, to be addressed during the body of the thesis.

\section{Historical Perspective}

"There are certain periods when political reform in Turkey took on a new elan, or became concentrated and comparatively rapid, and we might inquire what... stimuli were present on each occasion". ${ }^{70}$ For Roderic Davison writing in 1964 these periods were the Ottoman reforms culminating in the Young Turk revolution of 1908, the period of the establishment of the Turkish Republic from 1919 to 1926 and the half decade in which multi-party politics was born from 1945 to 1950. This section will roughly follow this structure with the addition of the period of military rule, 1980-1983. In looking into the various stimuli which contributed to these developments, it will concentrate on outlining the literature regarding the Turkish state and its changing relationship with civil society.

According to Halil Inalc1k, traditional Ottoman society consisted of two classes whose status was rigidly controlled by the divinelylegitimised role of the Sultan-Caliph. The first of these is described as the askeri - defined as "those to whom the Sultan had delegated religious or executive power through an imperial diploma, namely officers of the court and the army, civil servants and ulema". second class, the reaya, was all other subjects who paid varying amounts of tax, but, as "it was a fundamental rule of the Empire to exclude its subjects from the privileges of the military", took no part in government. ${ }^{72}$ Thus, as Ergun Özbudun notes, "with no feudalism comparable to that of Western Europe, no hereditary aristocracy, no

\footnotetext{
${ }^{70}$ Davison, R. (1964) p. 94.

${ }^{n}$ Inalc1k, H. (1964) p. 44. Here, the term ulema will be used to denote any religiouslylegitimated, state affiliated role.

72 Ibid. The author continues, "Only those among them who were actual fighters on the frontiers and those who had entered the ulema class after a regular course of study in a religious seminary could obtain the Sultan's diploma and thus become a member of the 'military' class".
} 
independent church hierarchy, no strong and independent merchant class, no self-governing cities, and with a ruling institution (i.e., the administration and the army) staffed with slaves, the Ottoman Empire represented a close approximation of an Oriental despotism" ${ }^{73}$ For Dodd, however, this absolutism was mitigated by the influence of the ulema, whose leader, the seybülislam, "had the great reserve power to issue a legal ruling that could sanction the deposition of the Sultan himself'.74 Frank Tachau supports this, pointing to Sultan-Caliph's immutable obligation to "ensure justice and promote welfare" enshrined within the tenets of the shariab. ${ }^{75}$ Concurring with Ilkay Sunar's contention that the Ottoman government was not so much ruled by force as by the "reciprocal tie of patronage", 76 he concludes that "the concept of governmental responsibility for material welfare (or economic development in present day terms) was well established in the Ottoman tradition".77 This arrangement was central to the strongly status-orientated social organisation of the Empire. According to Şerif Mardin, "not only did the state protect the guilds against monopolistic practices by merchants, but, more importantly, by denying corporate personality and independent government to towns, it blocked the formation of oligarchies of merchant capitalists". ${ }^{78}$

Faced with foreign encroachment upon its territorial periphery, the imperial government, requiring more and more funds to support its huge standing army of janissaries, replaced the traditional t1mar system with one of tax-farming whereby the right to collect taxes from the local agricultural community was delegated to the highest bidder and paid to the state in advance of harvest. ${ }^{79}$ Çağlar Keyder writes that by "extract[ing] the agricultural surplus from the independent peasantry", 80

\footnotetext{
${ }^{73}$ Özbudun, E. (1976) p. 28. His parenthesis.

${ }^{74}$ Dodd, C. H. (1969) p. 6.

${ }^{75}$ Tachau, F. (1984) p. 16.

${ }^{76}$ Sunar, 1. (1974) p. 5.

7 Tachau, F. (1984) p. 17.

${ }^{78}$ Mardin, S. (1969) p. 261.

${ }^{79}$ Kemal Karpat state that the tumar system was based on the principle that the title of much of the empire's arable land "belonged in perpetuity to the state" while the right to farm was possessed by the tenant $(1974$, p. 88$)$.

${ }^{80}$ Keyder, C.. (1987) p. 15. My parenthesis.
} 
local notables and guild-leaders, or ayan, ${ }^{81}$ used this new system to become, in Ergun Özbudun's view, "an intermediary,group between the rulers and the ruled". ${ }^{82}$ In other words a third class of tax-exempt public servants was added to the askeri/reaya dichotomy. This became particularly apparent during the acceleration of, what Ali Kazancigil calls, the process of "incorporation-peripheralisation" into the European economic system. ${ }^{83}$ The Turkish state, dominated by Tanzimat reformers, ${ }^{84}$ were increasingly concerned with the ayan classes as important elements of the economic periphery. As Josep LaPalombara and Myron Weiner point out, the state became absorbed in bringing these "discrete elements into meaningful participation in the political system" rather than pursuing the large-scale economic reforms apparent in Europe during the period. ${ }^{85}$ According to Mardin, this was attempted by "imposing new obligations - taxes, military service, various registration procedures - as well as by offering new benefits roads, the regulation of justice, land registration... [so that] by the end of the century, the aspects of Ottoman bureaucracy that could be called 'patrimonial' or 'sultanic' were giving way to a 'rational' bureaucracy". ${ }^{86}$ Metin Heper argues that, "not unlike the rationalist tradition of eighteenth-century Western Europe, the political conception underlying the Tanzimat was a direct relationship between the state and each of its subjects" ${ }^{87}$ This, as Albert Hourani has observed, was compatible with neither the privileges of the ayan nor with their role as intermediaries. ${ }^{88}$

\footnotetext{
${ }^{81}$ Used henceforth to include various other landed statuses and roles such as ağa, derebey, essraf etc.

${ }_{82}$ Özbudun, E. (1976) p. 30

${ }^{83}$ Ibid. passim.

${ }^{84}$ Literally renovation or re-ordering, the term Tanzimat refers to the period following the death of Sultan Mahmud II in 1839 to the Russo-Ottoman War of 1877-78 and culminating in the constitution a year earlier (Sugar, P., 1964, pp 152-153).

${ }^{85} \mathrm{LaPalombara}, \mathrm{J}$. \& Weiner, M. (1966) p. 413. "Even among the second generation of Tanzimat men we cannot find a single one who really had a clear understanding of economic issues or a sincere interest in them. Economic affairs did not enter into the traditional education of the Ottoman and were entrusted mainly to the Christian and Jewish subjects of the state" (Sugar, P., 1964, p.153). For an alternative position see Karpat, K. (1973a) passim.

${ }^{86}$ Mardin, S. (1973) pp 178-179. My parenthesis.

${ }^{87}$ Heper, M. (1985) p. 39.

${ }^{88}$ Hourani, A. (1968) passim.
} 
Thus the ayan's social position remained status rather than market determined, or what Kazancigil terms "prebendal", and "failed to develop beyond the local sphere a broader power base, autonomous from the state and the ruling elite". ${ }^{89}$ Şerif Mardin argues that each of these ayan households became, in effect, small replicas of the Ottoman state itself. He comments that "the most remarkable feature about this entire process is that an incipient market-orientated group could have been drawn to reproduce in miniature the lineaments of the state, instead of launching itself in new directions". ${ }^{90}$ Put another way, the ayan, as Çağlar Keyder suggests, represented, in their economic, but not political, mobility, "a failed attempt towards the formation of a feudalaristocratic class". ${ }^{11}$ Although commentators such as Ziya Gökalp (one of the foremost architects of the Kemalist revolution) point to ayan provincial resistance as the first real change in the prevailing power relationship between Ottoman state and subject, ${ }^{92}$ the failure of the notables to institutionalise a capitalist class meant that Ottoman commerce remained at a disadvantage relative to the mercantile dominance of western Europe. ${ }^{93}$ This helped to accelerate the periphery's economic incorporation into the West which, aided by the millet system, ${ }^{94}$ fomented further separatist irredentism. It also, as Özbudun contends, defined "the cleavage between the centre and periphery... [as] one between the political ins and outs, between the political elite and the rest of society",95 or, as Engin Akarl1 puts it, "the incumbents of the Ottoman institutions... [and the] people who were excluded from the state". ${ }^{6}$

\footnotetext{
${ }^{89}$ Kazancigil, A. (1981) p. 51

${ }^{90}$ Mardin, S. (1969) p. 267.

${ }^{91}$ Keyder, Ç. (1987) pp 15-16.

${ }^{92}$ Cited in Karpat, K. (1968) p. 79.

${ }^{93}$ See Mardin, S. (1969) p. 268.

${ }^{94}$ Walter Weiker states that the millet system "divided the population into religious communities, each of which had a great deal of autonomy in education, law and internal social, political and economic organisation... In most cities and towns the occupations which most exposed persons to the modern world, commerce and industry, were predominantly in the hands of non-Muslim minorities" (1981, p. 50).

${ }_{95}$ Ozbudun, E. (1976) p. 29. My parenthesis.

${ }^{96}$ Akarli, E. (1975) p. 139. My parenthesis
} 
Opposition to the centralising autocratic forces of the Tanzimat was not, however, reserved to the provinces. Frederick Frey describes "the development of severe intra-elite conflict between modernising sectors of the military and bureaucracy together with the new intelligentsia on the one hand, and a conservative coalition of the religious institution and other sectors of the military and bureaucracy on the other". ${ }^{97}$ Indeed, to quote Kazancigil, "the introduction of Westernised higher education institutions of the 1820 and 1830s and the establishment of secular public instruction led to... new professional groups [which] became dissatisfied with the inner circles of power, mostly staffed with traditional Ottoman state elites". ${ }^{98}$ These so-called Young Ottomans advocated the establishment of a representative parliament, but this, as Özbudun observes, "put them in a dilemma, one that was to be faced by many generations of future modernisers". .9 For, once this was convened, under a new constitution, in 1876, it "did not," according to Akarll, "increase the power of the modernising officials vis-à-vis the Sultan, but... it rather increased the power of notables against state officials". ${ }^{100}$ This was not an effect the Sultan nor either camp of reformers wished to promote and prompted the new system's almost instant dissolution.

Frank Tachau takes the view that, "at this point, the interests of the periphery coincided with the traditionalist group at the centre... [as] it became ever more clear that they [the Young Ottomans] intended to use their ideas and techniques to reinforce the power of the centre". ${ }^{101}$ Şerif Mardin supports this arguing that "the notables thus established a symbiotic relationship with officials, and bribing acquired a new dimension". ${ }^{102}$ This had some influence on the modernist movement who were, as Dodd notes, increasingly divided with "one group advocat[ing] a programme of Ottoman liberalism and decentralisation,

\footnotetext{
${ }^{97}$ Frey, F. (1978) p. 46.

${ }^{98}$ Kazancigil, A. (1981) p. 46. My parenthesis.

${ }^{99}$ Ozbudun, E. (1976) p. 36.

${ }^{100}$ Akarl, E. (1975) p. 143.

${ }^{101}$ Tachau, F. (1984) p. 21. My parentheses.

${ }^{102}$ Mardin, S. (1973) p. 178.
} 
whilst the other inclined strongly towards Turkish nationalism and centralisation... [and] which organised and carried out the Young Turk revolution of $1908 " .{ }^{103}$ Once in government the latter, known as the Committee of Union and Progress (CUP), advocated an etatist policy of Turkification "exclud[ing] the laissez-faire in favour of a more government-controlled 'national' or 'welfare' economy". ${ }^{104}$

With the outbreak of World War One securing the periphery took on a new significance and the CUP reversed their previously strongly secular rhetoric in favour of a call for Islamic unity. For, as Feroz Ahmad notes, it firstly "helped protect their flank from the right and facilitated the legitimisation of their policies; and second, Islamic solidarity became much more important after the loss of the mainly Christian Balkans in 1912-13". ${ }^{105}$ David McDowall agrees noting that, "the CUP revived the Hamidian [Sultan Abdul Hamid, in power from 1876 to 1909] pan-Islamic policy"106 and, as Kemal Kirişci and Gareth Winrow continue, "established the protection of the Sultan and Caliph and a commitment to the independence of Ottoman territories [as] the basic elements of Ottoman patriotism". ${ }^{107}$ While this was clearly an effective rallying point, many, as Tachau records, believed that "the Young Turk regime had forsaken traditional Islamic values, ways and principles in favour of infidel, Western ways" and, with defeat and capitulation, it was hard for the remnants of the CUP, operating from an occupied Istanbul, to remain credible. ${ }^{108}$ Military failure, and the subsequent territorial losses under the punitive Treaty of Sèvres, also prevented any return of popular support for the decentralisation movement. As Dankwart Rustow points out, "with the Turks left as the major ethnic element loyal to the Empire, the federalists demand for a 'unity of elements' had become hollow and illusory". ${ }^{109}$ The centralist cause was again furthered by the Allied-supported Greek invasion at Izmir and

${ }^{103}$ Dodd, C. H. (1969) p. 14. My parentheses.

${ }^{104}$ Özbudun, E. (1976) p. 39. My parenthesis, his emphasis.

${ }^{105}$ Ahmad, F. (1991) p. 5.

${ }^{106} \mathrm{McDowall}, \mathrm{D}$. (1992) p. 127. My parenthesis.

${ }^{107}$ Kirişci, K. \& Winrow, G. M. (1997) p. 91. My parenthesis.

${ }^{108}$ Tachau, F. (1984) p. 25. My emphasis.

${ }^{109}$ Rustow, D. (1966) p. 117. 
Italian landings at Antalya in May 1919, significantly adding to fears of Christian domination.

Mustafa Kemal, the hero of the Dardanelles and former commander of the Ninth Army, emerged as leader of a movement which the Grand Vizier, Izzet Pasha, described as being "made up for the most part of military commanders and their staffs, country notables and of intellectuals". ${ }^{110}$ This, according to Mardin, was something of an uncomfortable alliance largely based on the forced recognition that "the religious and non-religious notables together made up local power in the Ottoman provincial cities" and it was therefore essential to coopt their support for any populist endeavour to succeed. ${ }^{111} \mathrm{Kemal}$ was careful, as McDowall notes, "to launch his war of independence by appealing to all Muslims to rally to the cause of the Sultan-Caliph, who was imprisoned at Constantinople by the infidel allies", rather than by promoting any longer-term objectives. ${ }^{112}$ Initially then, it was perhaps the Kemalists' willingness and ability to support the call to jibad with military action that promoted their appeal to the provincial nobility. ${ }^{113}$ Moreover, following the establishment of his National Assembly in Ankara in April 1920, Kemal not only offered to protect these sheikhs and ağas, but, as Michael Van Bruinessen notes, he also "had power that he might delegate to them, whereas the [peripheral] nationalist organisations did not". 114

The Ankara government, however, became increasingly concerned that the 'de-Islamisation' of politics under the CUP had not gone far enough and that the inherently diffuse, a-national ideological basis of the Sultan-Caliph had to be replaced "with a modern secular ideology and the values of republican nationalism". ${ }^{115}$ Kirişci and Winrow argue

\footnotetext{
${ }^{110}$ Quoted in ibid. p. 119.

${ }^{111}$ Mardin, S. (1971) p. 208.

${ }^{112}$ McDowall, D. (1992) p. 127

${ }^{113}$ It is perhaps unsurprising that they opted for the security of their ancient position as the subjects of the Porte, enshrined as it was in the office of the Caliph, rather than the tenuous promises of Wilson's new world order and the Sykes-Picot arrangements (revealed by the Bolsheviks in 1918).

${ }^{114}$ Van Bruinessen, M. (1992) p. 279. My parenthesis.

${ }^{115}$ Tapper, R. (1991) p. 6.
} 
that, as the Ottoman empire continued to disintegrate, "Mustafa Kemal and his supporters were confronted with the need to build a new order. For them 'Turkishness' would become the basis for a new national identity" and the ideology that would replace Islam as the unifying bond in a modern political community. ${ }^{116}$ The Ankara government saw the nation as "not a racial, ethnic, geographical, political, or voluntary group or association", but rather a social group who simply inhabited the same land, were bound by the same laws, shared a common morality and language and possessed the will to live together. ${ }^{117}$ Closely tied to this concept of nationalism was the notion of etatism defined by Kemal as "the intervention of the state in all spheres, whenever the general interests of the nation are involved". ${ }^{118}$ According to flter Turan, the Ottoman bureaucracy was further strengthened and centralised as the state began to judge "its extensions on the periphery in terms of how well they carried out westernisation policies". ${ }^{119}$

This, for Kirişci and Winrow, resulted from "the absence of a democratic tradition in the Ottoman and then the Turkish polity... [which made] it exceedingly difficult for decision-makers in Ankara to pursue a policy based on real civic integration as opposed to ethnic nationalism". ${ }^{120}$ Instead, as Ellen Kay Trimberger contends, "because military and civil bureaucrats did not stage a coup, but rather established a counter-government in the process of overthrowing the old regime, they were able to initiate rapid change after taking power". ${ }^{121}$ For instance, Article One of January 1921's Law on Fundamental Organisation declared that "sovereignty, without any preconditions, belongs to the nation" and Article Three stated that the national executive would be "the governing body of the state of Turkey". ${ }^{122}$ Both of which represent a significant departure from the multi-national ideology of the Ottoman empire. Moreover, Kemal

\footnotetext{
${ }^{116}$ Kirişci, K. \& Winrow, G. M. (1997) p. 94.

${ }^{117}$ Z. Gökalp in Berkes N. (1959) p. 137.

${ }^{118}$ Quoted in Dumont, P. (1984) p. 39.

119 Turan, I. (1984) p. 108.

${ }^{120}$ Kirişci, K. \& Winrow, G. M. (1997) p. 97. My parenthesis.

${ }^{121}$ Trimberger, E. K. (1978) p. 18.

${ }^{122}$ Translated and cited by Kirişci, K. \& Winrow, G. M. (1997) p. 93.
} 
increasingly emphasised the 1500-year-old history of the Turks as opposed to the 700-year-old Ottoman empire and in November 1922 he announced the abolition of the Sultanate and the creation of the Turkish Republic.

Having solidified the borders and status of the new Turkish state at Lausanne in July 1923, Kemal turned towards the ulema and, the following March, abolished the Caliphate. This was followed by the delegitimisation of religious instruction in favour of a centralised and secular Ministry of Education ${ }^{123}$ and the replacement of the Arabic script with öztürkfe..$^{124}$ In what, for Metin Heper, "was to resemble the Protestant tradition that placed emphasis on the absolute privacy of individual conscience... all public displays of religious observation were discouraged" and the clergy was incorporated into the civil bureaucracy. ${ }^{125}$ According to Bülent Daver these were ostensibly carried out "to 'purify' Islam and to open the gate for a reformist Islamic thought..., to liberate society from the hold of Islam and to bring about a new type of free individual" and, as Sunar contends, to replace state with society as "the ultimate basis of authority". ${ }^{126}$ This concept of sovereignty residing within the citizenry was part of Kemal's efforts "to suppress the class or strata differences and to replace them with a social structure composed of occupational groups". ${ }^{127}$ Paul Dumont suggests that these views were strongly influenced by notions of corporatism and the narodnik socialism of Tsarist émigrés within the periphery. ${ }^{128}$ Furthermore, it was "also politically utilitarian in that it helped to legitimate the single party as the sole representative of all elements of society". ${ }^{129}$

\footnotetext{
123 "The building of the nation-state was thus accompanied by the centralisation of education and the formation of its nationalist elites" (Göle, N., 1997, p. 49)

${ }^{124}$ Pure Turkish'. Foreign languages, including Kurdish and the Arabic call to prayer, were also banned.

${ }^{125}$ Heper, M. (1981) p. 351.

${ }^{126}$ Daver, B. (1967) p. 55 \& p. 62 and Sunar, 1. (1974) p. 54.

${ }^{127}$ Gökalp quoted by Dumont, P. (1984) p. 32

${ }^{128}$ Ibid.

${ }^{129}$ Weiker, W. (1981) p. 6.
} 
Mardin argues that "Atatürk thus chose to strike at the foundations of official religion, making... republican laicism... a legitimating framework for the religion of the lower classes". ${ }^{130}$ Nilüfer Göle, however, points out that "although Turkish secularism is inspired by the French 'laicite' or separation of church and state, religious affairs in Turkey are regulated by the state... Hence, secularisation itself became part of that process of social engineering rather than an outcome of the process of modernisation and societal development". ${ }^{131}$ Paul Dumont supports this, writing "Mustafa Kemal and his associates were far too aware of the power of religion to put it entirely into private hands. They could not allow the development of fully independent religious institutions which sooner or later might oppose the regime". ${ }^{132}$ Instead, as Count Ostorog, the French Ambassador, put it, "religion was merely caused to recede from the halls of human conflict. It was to ascend to the stronghold of conscience to dwell there in much greater dignity and security". ${ }^{133}$

However, despite Mustafa Kemal's authoritarian organisation of many previously de-centralised aspects of social interaction, his administration "also kept its own stable of notables, ones who would serve the regime against its enemies... not for any ideological reason, but to acquire material advantage or to worst a local rival". ${ }^{134}$ During the 1920s and 30s these rural elites extended their position by building corporatist linkages with both emergent urban capitalists and the state bureaucracy. Having profited heavily from these connections and from the increases in agricultural produce during of the Second World War, they began to pressure the state for greater political representation and an end to the one-party system which finally came about in 1946. This was for two distinct reasons. Firstly, as Ahmet Samim argues, "with the lure of American aid and the threat of Soviet demands for war-rights over the Straits and eastern territories, it [Turkey] turned sharply

\footnotetext{
${ }^{130}$ Mardin, S. (1971) p. 208.

${ }^{131}$ Göle, N. (1997) p. 48.

${ }^{132}$ Dumont, P. (1984) p. 38.

${ }^{133}$ Quoted in Smith, W. C. (1957) pp 193-4.

${ }^{134}$ McDowall, D. (1992) p. 397.
} 
toward the United States" and its emphasis on multi-party democracies. ${ }^{135}$ William Hale comments that "although [President] Inönü was reluctant to admit it, the need to win friends in the West was almost certainly an important factor in determining his attachment to liberalism". ${ }^{136}$ Secondly, following the death of Kemal in 1938 his party, the Cumburiyet Halk Partisi (Republican Peoples' Party - RPP), was challenged from within by a rising generation of bourgeois, liberaleducated industrialists and large-estate farmers who were tired of the state bureaucracy's interventionist economic policies. Dissent polarised around the RPP's attempts to slow the ascendancy of the economic elite through the Land Reform Bill of January 1945. Thus, as Turan notes, the Kemalist "alliance between the bureaucratic elite, the economic middle class and local notables was irreparably shattered". ${ }^{137}$

Within a year, an opposition Demokrat Partisi (DP) led by Adnan Menderes, a wealthy landowner and farmer from the western Aegean region, was established. Karpat argues that the competition for votes quickly "forced both the Republicans and the Democrats to establish thousands of party organisations throughout the villages and towns of Turkey, which became centres of political education and social mobilisation". ${ }^{138}$ In the ensuing scramble for constituents McDowall notes that "the Democrats presented themselves as the party of private property, and made agriculture the cornerstone of their electoral appeal, arguing that large estates would be most productive and profitable". ${ }^{139}$ The RPP, in contrast, found it difficult to escape the unpopularity of the pre-war policies in the periphery. As Özbudun observes, "the Turkish rural masses were further alienated by the economic hardships of the World War II years and the authoritarian methods of the bureaucracy... [which] came to be identified with the gendarmerie and the tax collector". ${ }^{140}$ In the view of Serif Mardin, "the

\footnotetext{
${ }^{135}$ Samim, A. (1987) p. 152. My parenthesis.

${ }^{136} \mathrm{Hale}$, W. (1994) p. 90 . My parenthesis. Inönü had taken over the presidency following Kemal's death in 1938.

${ }^{137}$ Turan, 1. (1984) p. 113.

${ }^{138}$ Karpat, K. (1964) p. 58.

${ }^{139} \mathrm{McD}$ owall, D. (1992) p. 398.

${ }^{140}$ Ozbudun, E. (1976) p. 45. My parenthesis.
} 
new party promised it would bring services to the peasants, ...debureaucratise Turkey and liberalise religious practices. Finally, private enterprise, equally hampered by bureaucratic controls and angered by its dependence on political influence, was also promised greater freedom". ${ }^{141}$ These were the issues which "had their roots in the alienation from the centre" and which won the DP 81 per cent of the seats in the 1950 elections. $^{142}$

In pursuit of economic development, the Minister of Management, Muhlis Ete, argued that "the state should not be involved in enterprises which are not of a public character. It should begin, gradually and according to a programme, to turn over all other enterprises ...to private enterprise and co-operative groups". ${ }^{143}$ However, "by philosophy and temperament the Democrats were alien to bureaucratic "procedures" which, coupled with the fact, that they "found that the social class which embodies the values of the private entrepreneur was very small and underdeveloped" meant that their primary objective of capitalist development was only partly met. ${ }^{144}$ In many ways, they were subject to the vicious circle in which countries such as Turkey "have to create a larger middle class before they can effectively draw talent from it... [but] development is necessary to a create a larger pool of middleclass entrepreneurial talent which makes development possible". ${ }^{145}$

Çağlar Keyder concurs commenting that "in addition to the impoverishment of the institutions which might have provided the basis for a civil society, the dominant tendency in economic policy also worked toward inducing the bourgeoisie to passivity". ${ }^{146}$ Since, he continues, "the parliament was both younger and more provincial" and American aid arrived with sectoral tags attached, "it was understandable

\footnotetext{
${ }^{141}$ Mardin, S. (1973) p. 184.

142 Ibid. "Almost 90 per cent of the registered voters came to the polls and gave the Democrats 53.35 per cent of the vote and 408 seats, while the RPP won 38.38 per cent of the vote but only 39 seats in the new Assembly". Ahmad, F. (1993) p. 109.

${ }^{143}$ Quoted in Ahmad, F. (1977) p. 126.

${ }^{144}$ Ibid. pp 127-128.

${ }^{145} \mathrm{McClell}$ and, D. (1967) p. 262. My parenthesis.

${ }^{146}$ Keyder, C.. (1987) p. 199.
} 
that the DP leaders would shift their attention to agricultural development". ${ }^{147}$ Their reliance on the market as the principal mechanism to allocate economic resources proved initially successful. GNP rose from 38,506 million TL in 1950 to 70,869 million TL in 1960 and the proportion of land-less village families declined from 16 to 10 per cent over the same period. ${ }^{148}$ Nevertheless, Walter Weiker argues that "much of the increase in agricultural production was a result merely of an increase in cultivated area" and does not represent any degree of land reform. ${ }^{149}$ David McDowall agrees, pointing out that this was particularly apparent in the south-east of Anatolia where, "many small farmers and landholders ended up selling off their land to the tractor owning magnates and being put out of work. ${ }^{150}$

The economic elite, well represented in parliament and profiting from the reduction of state intervention, fared well from, what Karpat calls, "the growing association of politics with economic interests". ${ }^{151}$ For instance, according to Ahmad, "the Democrats encouraged production... by instituting an agricultural price policy unduly favourable to the producer. At the same time, agricultural incomes were not taxed, with the result that the landowners prospered and accumulated considerable wealth". ${ }^{152}$ As Mann points out, "If the state upholds given relations of production then the dominant economic class will have an interest in efficient state centralisation" and civil society groups will tend to endorse state power. ${ }^{153}$ For much of the periphery then "the developing bourgeoisie was," Keyder concludes, "an exceptionally 'national' one in its practical orientation". ${ }^{154}$ In other

\footnotetext{
147 Ibid. p. 127.

${ }^{148}$ See ibid. p. 131 \& Keyder, Ç. (1987a) p. 295.

149 Weiker, W. (1981) p. 196. Feroz Ahmad writes in support of this that "the government did distribute about 1.8 million hectares to about 360,000 families between 1947 and 1962, but only 8,600 hectares were taken from private land. Almost all the land distributed belonged to the state and was already in use as grazing" (Ahmad, F., 1977, p. 134).

${ }^{150}$ According to Atkan (1957, p. 276) the numbers of tractors in Turkey increased from 1,756 in 1948 to 43,727 in 1956 . He also notes comparable expansion in other types of mechanisation.

${ }^{151}$ Karpat, K. (1973) passim.

${ }^{152}$ Ahamd, F. (1981) p. 136.

${ }^{153}$ Mann, M. (1984) p. 204.

${ }^{154}$ Keyder, C.. (1987) p. 199.
} 
words the DP simply took the place of the RPP while leaving the organisational structure of the peripheral economy infra-structurally undisturbed; Diyarbakir province was, for example, electorally controlled by less than twenty landlords throughout this period. Indeed, as Weiker contends, "farm mechanisation tended to disproportionately benefit the larger farmers... and would soon be one cause of dislocating large numbers of peasants and generating severe 'push' pressures toward rapid urbanisation". 155

Another was the economic down-turn in the mid to late 1950s which significantly worsened the conditions of seasonal and tied farmers forcing hundreds of thousands off the land to join the industrial proletariat of the main urban centres. This, of course, "meant that an even larger area of cultivable land came under the control of the big landowners". ${ }^{156}$ Singer has noted that as the construction industry boomed and the number of workers in urban plants with more than ten employees rose from 163,000 to 324,000 in the latter half of the 1950s and shanty towns, or gecekondu, began to appear in most Turkish cities. ${ }^{157}$ As McDowall records, the majority of migrants were Kurdish speakers, ${ }^{158}$ many of whom "established permanent strongholds of Kurdish identity across the republic... mak[ing] the Kurdish question a visible reality for the citizens of Istanbul 800 miles away from Kurdistan". 159 Thus, in Keyder's view, "social lines came to be drawn along geographical differences... [which] reinforced solidarities in the labour market and political rivalries were inevitably superimposed on such divisions" ${ }^{160}$

This polarisation and radicalisation of Turkish politics during the 1970s provoked a reassertion of military power. The 1960s had been what

${ }^{155}$ Weiker, W. (1981) p. 268.

${ }^{156}$ Berberoğlu, B. (1982) p. 71. He continues "...large sums of money and credits were channelled directly to the big landowners... increas [ing] from 3 million TL during 194550 to 9.7 million TL during $1950-56 "$. My parenthesis.

${ }^{157}$ Singer, M. (1977) p. 242 and p. 295.

${ }^{158}$ They went to Istanbul (41\%), Ankara (18\%), Adana (15\%) and Izmir (4\%) (McDowall, D., 1992, p. 401).

${ }^{159}$ Ibid. p. 402. My parenthesis.

${ }^{160}$ Keyder, C.. (1987) p. 206. My parenthesis. 
Berberoğlu describes as, "a decade of intense struggle"161 which had seen the annual number of workdays lost to strikes rise from 19,739 to $476,116{ }^{162}$ The 1970 s continued this trend in "a rising tide of political violence", which, as Frank Tachau observes, "reached its climax in 1980, culminating in the military coup of 12 September". ${ }^{163}$ Ilter Turan argues that partly to blame was an "instability of political parties at the local, national and parliamentary level owing to the ineffective operation of intra-democracy... [and] political parties function[ing] as clientelistic networks through which benefits deriving from being in government would be distributed". ${ }^{164}$ Indeed, Ahmet Evin concurs, contending that "government patronage to reward party supporters through civil service appointments became a frequent and widespread practice in the wake of constantly changing coalition governments". ${ }^{165}$ This, according to John McFadden, was exacerbated by "a proportional representational system of distributing seats in the Grand National Assembly [which] had encouraged a surfeit of political parties. Lowered restraints on the variety of political philosophies that would be tolerated", he continues, meant that "no party was able to obtain a majority and the legislative process [became] bogged down". ${ }^{166}$

As a result of what Tachau and Heper describe as "a lack of decisive authority on the part of the government, polarisation came to characterise not only the parties, but was insinuated into other important social sectors as well, including organised labour, the teaching profession, the civil bureaucracy, and even the police". ${ }^{167}$ According to George Harris this materialised into three broad categories of violence; ideological, sectarian and ethnic. ${ }^{168}$ Leftist groups fought against the 'Grey Wolves' of Alparslan Türkeş' National Action Party (Milliyet Hareket Partisi - NAP), Sunni against Alevi and

\footnotetext{
161 Berberoğlu, B. (1982) p101.

${ }^{162}$ Reported in Işılkl, A. (1987) p. 316 and p. 325.

${ }^{163}$ Tachau, F. (1984a) p. 71.

${ }^{164}$ Turan, 1. (1988) p. 65.

${ }^{165}$ Evin, A. (1988) p. 206.

${ }^{166}$ McFadden, J. (1985) p. 69. My parentheses.

${ }^{167}$ Tachau, F. \& Heper, M. (1983) p. 24.

${ }^{168}$ Harris, G. (1980) pp 36-38.
} 
Kurd against Turk. ${ }^{169}$ In 1978 alone there were more than 4,000 separate acts of political violence and by the summer of 1980 an average of 183 lives were being lost each month. ${ }^{170}$ In response, and increasingly fearful following the fall of the Shah in Iran in February 1979, the government imposed martial law in nineteen provinces, most of which were in the south and south-east, thus "becoming ever more dependent on the armed forces". ${ }^{171}$ Harris, however, argues that even "this ineffectual effort to promote law and order took place against the backdrop of bickering among the politicians who continued to dispute over the duration and scope of martial law and other issues important to the armed forces". 172

More generally, the population of the country had risen from eighteen million in 1940 to forty-four million by 1977 with forty-four per cent under the age of fifteen and 360,000 students competing for 60,000 university places. ${ }^{173}$ As noted, huge numbers of people came to the major cities producing what Şerif Mardin describes as the 'ruralisation' of urban life. ${ }^{174}$ The twofold result of this, he argues was, "on the one hand, village problems, now not even resolved at the village level, were let loose in a much wider social field. On the other, the Kemalist ideology which would have re-shaped world-views for candidates to elite status was also eroded". ${ }^{175}$ Kemal Karpat contends that these burgeoning gecekondu changed in significance from functional transitional communities facilitating integration into urban industry to focal points of alienation and disaffected identification for the children of the first generation of migrants. ${ }^{176}$ His conclusions are supported by Doğu Ergil's empirical study of 287 terrorist prisoners in Ankara jail

\footnotetext{
${ }^{169}$ The term Alevi is is used here to mean "the mixture of Shii Islam, Persian Mazdeism, Christianity and possibly Central Asian ideas adopted by the Turkomen and Kurdish tribes inhabiting an area in Eastern Anatolia at the beginning of the sixteenth century" (McDowall, D., 1989, pp 8-9).

${ }^{170}$ Milliyet, December 31"t, 1978, p. 9 and Cumburiyet, April 6" 1981 respectively.

${ }^{171}$ Harris, G. (1985) p. 166.

172 Ibid.

${ }^{173}$ Mardin, S. (1978) p. 244 and p. 250.

${ }^{174}$ Ibid. p. 244.

175 Ibid. p. 246.

${ }^{176}$ Karpat, K. (1976) passim and (1981) pp 18-19.
} 
which identified a high positive correlation between political activism, rural-urban migration and the failure to prosper within the educational and economic systems. ${ }^{177}$

William Hale suggests that, "although a majority of gecekondu dwellers maintained their independence, many of the youth fell under the domination of violent radical political organisations, of both left and right, which seemed to offer a crude way out of their social and economic failures and frustrations". ${ }^{178}$ According to Kirişci and Winrow, many of the former, such as Dev Genc, ${ }^{179}$ argued that "the pursuit of capitalist and imperialist policies had led to the denial of Kurdish identity and the lack of economic development in eastern Anatolia". ${ }^{180}$ By the mid-70s, however, leading Kurds among these groups had begun to call for Kurdistan to be recognised as a separate nation capable of organising its own proletarian tevolution. ${ }^{181}$ As Van Bruinessen has contended this succeeded in "changing the selfperception of a considerable section of the Kurds. People who had long called themselves Turks started re-defining themselves as Kurds". ${ }^{182}$

Founded in 1974 by Abdullah Öcalan, the Kurdish Workers' Party (Partiya Karkareni Kürdistan - PKK) was, according to Nicole and Hugh Pope, "among the most virulent of the armed groups ...on Turkey's Marxist fringe" "Th3 . Their manifesto "depicted the Kurdish populated areas as a colony and argued that the Kurdish feudalists and bourgeoisie had chosen to collaborate with the Turkish ruling classes to exploit the Kurdish peasantry and working class". ${ }^{184}$ Although the

\footnotetext{
${ }^{177}$ Ergil, D. (1980) pp 129-137.

${ }^{178}$ Hale, W. (1994) p. 227.

${ }^{179}$ Also known as The Federation of Turkish Revolutionary Youth, it was notoriously violent in its "struggle against fascism and imperialism, for ideological independence and the liberation of peoples". Landau, J. (1974) p. 86.

${ }^{180}$ Kirişci, K. \& Winrow, G. M. (1997) p. 109.

${ }^{181}$ Gunter, M. (1990) pp 63-68.

${ }^{182}$ Van Bruinessen (1989) p. 621.

183 Pope, N. \& Pope H. (1997) p. 259.

${ }^{184}$ Kirişci, K. \& Winrow, G. M. (1997) p. 110.
} 
battleground was, and has remained, the stubbornly rural south-east, ${ }^{185}$ the essence of the PKK, including its support, was in the gecekondu of the larger urban centres. Its leaders came from the political science classes of prestigious universities and its resources from Syria and smuggling. ${ }^{186}$ Rather than exclusively assaulting the state, the PKK's primary targets were statist land-owners involved local politics. ${ }^{187}$ Indeed, according to Kirişci and Winrow's findings, the PKK have consistently targeted a higher number of non-combatants than members of the security forces. ${ }^{188}$

It is perhaps, as Tachau and Heper remark, "to be wondered why the military did not intervene much earlier than September 12, 1980". 189 The 1960 military intervention had, after all, strengthened their position originally enshrined within Kemal's 1924 constitution which had charged them with the "definition, determination and application of a national security policy" in order to protect "the indivisible unity of the state's people and its territory". ${ }^{190}$ Under Article 11 of the 1961 Constitution a 'National Security Council' (NSC), made up of selected cabinet members, the Chief-of-Staff and serving force commanders, had, in Muller's words, "established the military's profound influence over all state institutions". ${ }^{191}$ This influence is quantified by Ihsan Dag1 as being born of two conflicting political traditions; firstly, "the selfascribed guardian role of the military which is legitimised by the role of military elites in forming the republic and a national security ideology,

\footnotetext{
${ }^{185}$ In many south-eastern towns and a day's salary for an adult male labourer was reported by Le Monde on June $16^{\text {th }} 1983$ as US $\$ 2$.

${ }^{186}$ James Brown argues that Syria's support for the PKK stems from concerns over proposed hydro-electric schemes that may affect water flows on the Euphrates river, as well as historical claims on the territory of Hatay which was incorporated into Turkey by popular referendum in 1939 (1995, p. 125). The Popes stress the revenue generated by the processing and sale of opiates claiming that up to 80 per cent of Britain's heroin goes through south-east Turkey (1997, p. 277).

${ }^{187}$ For instance, in August 1979 Öcalan's men attempted to assassinate Mehmet Celal Bucak, landlord and Justice Party deputy of twenty villages around and including the town of Siverek. It is unclear if this was due to his political allegiances, his allegedly exploitative economic practices or at the behest of a rival (Financial Times $21^{*}$ January and October $1^{\text {st }} 1980$ ).

${ }^{188}$ Kirişci, K. \& Winrow G. M. (1997) p. 126.

${ }^{189}$ Tachau, F. \& Heper, M. (1983) p. 25.

${ }^{190}$ Cited in Gürbey, G. (1996) pp 12-13.

${ }^{191}$ Muller, M. (1996) p. 177.
} 
gives rise to interventionist and authoritarian tendencies. Secondly, ... [its role] as a modernising force since the nineteenth century". ${ }^{192}$ This appears to be largely coterminous with Eric Nordlinger's 'guardian' type of military regime in that they "intend[ed] to correct what [we]re seen to be the malpractices and deficiencies of the previous government" squabbling politicians, revamp the machinery of government and redistribute some political power and economic rewards". ${ }^{194}$

Ahmet Evin, however, takes the view that as "the military were the last homogenous group left, defined along institutional lines, it is not surprising that they acted as the sole representatives of the state" and concludes that "the 1980 regime was guided more by the objective of establishing military authority over the state than restoring the authority of the state". ${ }^{195}$ To this end some 18,000 civil servants received administrative or penal punishments, 1,700 elected mayors were dismissed ${ }^{196}$ and the new President, General Kenan Evren, was, as Heper writes, "granted extensive legislative and executive powers". 197 By doing this, the military "aimed at close hierarchical control of the civil bureaucracy". ${ }^{198}$ Kemal Karpat agrees, noting that "the wide approval of the military by the people was particularly necessary in 1980 because, unlike the interventions of 1960 and 1971, this one did not have the organised support of a political party or social group". ${ }^{199}$ This was forthcoming in the constitutional referendum of November 1982 in which voter participation was 91.27 per cent of which 91.37 per cent were in favour of the regime's new powers. Although Kirişci

\footnotetext{
${ }^{192}$ Dag1, I. (1996) p. 124. My parenthesis.

${ }^{193}$ Nordlinger, E. (1977) p. 25. My parentheses. He also identifies the moderator and ruler type as less and more interventionist respectively.

${ }^{194}$ Tachau, F. \& Heper, M. (1983) p. 28.

${ }^{195}$ Evin, A. (1988) p. 211. A priority connected to this was "the need to preserve unity and the command hierarchy within the army" (Hale, W., 1988, p. 163).

${ }^{196}$ Figures reported in Hürriyet, January $6^{\text {th }}, 1981$. Lucille Pevsner records that between September 1980 and February 1983 over 60,000 people suspected of illegal political activities were arrested $(1984$, p. 88$)$.

${ }^{197}$ Heper, M. (1985) p. 141. This "extends the junta's desire to give the president effective control over other institutions in order to guard against what was perceived as excessive politicisation of these organisations" (Tachau, F. \& Heper, M., 1983, p. 29).

${ }^{198}$ Heper, M. (1990) p. 220.

${ }^{199}$ Karpat, K. (1988) p. 150.
} 
and Winrow argue that "little public debate was permitted... and the stark yes or no options gave people little room for choice", ${ }^{200}$ Karpat takes the view that the military's reassertion of power, "conform[s] to the traditional Turkish patterns of government and are to a large extent outside the citizen's immediate concern". ${ }^{201}$

The 1982 Constitution, in which the "military regime sought to buttress its role in the successor civilian government", ${ }^{202}$ reduced the civilian members of the NSC to a minority and led many commentators, such as G. Gürbey, to argue that their presence "in the political system impedes and hinders the pluralisation, democratisation and development of a civilised society". ${ }^{203}$ Indeed, as Binnaz Toprak concludes, "the new constitution rejected a major premise of pluralist democracy, namely the representation of interests through links with political parties and interest groups. It also rejected the principle... that institutions of civil society are, by definition autonomous from the state". ${ }^{204}$ This was underpinned by new laws in April 1983 which, while removing the previously complete ban on political parties, gave the NSC the power to "investigate and declare unsuitable"205 party members or candidates and insisted on manifestos remaining "attached to the principles and reforms of Atatürk". ${ }^{206}$ Aimed at institutionalising a two-party system, the new laws also decreed that each party was obliged to establish organisations in at least half of Turkey's provinces. These were augmented with further legislation in June of the same year which required parties to win at least 10 per cent of the national vote to gain any seats and segmented the most populous electoral districts into smaller, less gecekondu-influenced boroughs. According to Ergüder and Hofferbert, the new system was successful in "further reducing the

\footnotetext{
${ }^{200}$ Kirişci, K. \& Wintow G. M. (1997) pp 111-112.

${ }^{201}$ Karpat, K. (1988) p. 154. My parenthesis.

${ }^{202}$ Hale, W. (1994) p. 290.

${ }^{203}$ Gürbey, G. (1996) p. 13. He continues by arguing that the NSC still "plays an active and determining role in the definition and application of policy aims, ... is in no way responsible to Parliament [and] ... is the primary decision-maker in the Kurdish issue". My parenthesis.

${ }^{204}$ Toprak, B. (1988) p. 127.

${ }^{205}$ Cumburiyet, April 26 $6^{\text {th }}, 1983$.

${ }^{206}$ Cited in Hale, W. (1988) p. 170.
} 
tendency of a proportional system to reward minor parties and to fragment the party system". 207

It also meant, however, that political groups representing Kurdish issues were unable to operate, even if they complied with Article 68 of the Constitution preventing activities "in conflict with the indivisible integrity of the state". 2018 As "the generals seized power determined to solve the Kurdish question by force just as they intended to solve all other issues", ${ }^{209}$ it is, for commentators such as Feroz Ahmad, hardly surprising that Article 26 of the Constitution, which had decreed that "no language prohibited by the state shall be used in the expression and dissemination of thought", was, in October 1983, qualified with 2 ban on the use of Kurdish. ${ }^{210} \mathrm{Kirişci}$ and Winrow argue that, "the political discourse derived from these policies put clear emphasis on the Turkishness of Turkey', the unity of the nation and its territorial integrity. There was a major backlash against the conspicuous growth of expressions of Kurdish nationalist ideas". ${ }^{211}$ This was particularly apparent in the south-east itself where, according to Chris Kutschera, "the extent and ferocity of the repression decimated the Kurdish parties... The regime thus cleared the way for the PKK" who launched their first large-scale armed attack on the villages of Eruh and Semdinli on the $15^{\text {th }}$ of August $1984 .^{212}$

\section{Conclusion}

From this account of the theoretical literature regarding social power and the state and from the historical analysis of Ottoman/Turkish state

\footnotetext{
${ }^{207}$ Ergüder, 0. \& Hofferbert, R. (1988) p. 83,

210 General Evren elaborated on his government's position by stating that "what lies at the basis of the Turkish Republic... is the sublime philosophy of Atatürk which says 'Happy is he who calls himself a Turk'. This philosophy includes every citizen uto considers himself a Turk, regardless of creed, race or religion" (quoted in Heper, M.,1 1985, p.132). In imposing this he later announced that "tens of thousands of persons belonging to Lefrist organisations are daily being shot or wounded or captured and handed over to the judiciary" (quoted in Ahmad, F., 1993, p. 184).

2n Ahmad, F., (1993) p. 218.

${ }^{210}$ T. C. Resmi Gariti, October $22^{\text {nd }}, 1983$.

21" Nirisci, K \& W'inrow G. M. (1997) pp 110-111.

${ }^{213}$ Kutschera, C. (1994) p. 13.
} 
development a number of questions emerge. While these will be looked at in more detail, and critically analysed, in the coming chapters, it is worth setting them down at this stage. This will serve to highlight some of the more important aspects of debate and areas of contention, as well as issues yet to receive sufficient study, which this thesis will later address in a more systematic way.

Having set out an account of Mann's theoretical and historiographic position in the next chapter, Chapter Three will use his framework to consider issues relating to the politics of Ottoman change. Not least among these, is the question of who ran the Ottoman empire? Is Michael Mann's assertion that the state is essentially territorially determined and socio-spatially centralised a helpful means of analysing Ottoman policy? Is he correct to assert that all pre-modern empire's were structured by a 'three-way power stand-off between state, ruling class and the masses? How was social power organised by the Ottoman state and what level of autonomy did it possess? Is Mann's notion of the duality of state power, as simultaneously infra-structural and despotic, an expedient method of conceptualising the Ottoman state's relationship with civil society and the ayan? Who are the ayan? How were they related to the askeri and reaya classes? What was the basis of their economic mobility and why was it not convertible into political influence? Were the ayan classes coterminous with the 'periphery? What level of autonomy from the state did they enjoy and how did changes in state administration affect their status and role? Can this shift in state-subject power relations be regarded as the beginning of the end of the Ottoman Empire? How was the evolution of the state subject to the changing international system in the nineteenth century? What factors, internal to the Empire, contributed to changes in the organisation of social power by the state? Can Mann's model of state power be workably employed to account for these changes? 
Chapter Four will use Mann's analysis of ideological change in Europe to examine issues connected to late Ottoman and early republican 'modernism'. A key question will be how the appeal of faith was organised by the state as a means of securing unity. What role did Islam have in the creation of an assimilated nation state? How did the ulema's influence and authority relate to Kemal's homogenous and secular vision of a modern Turkey? What was the process of ideological reordering that took place? Was it, in Mann's terms, able to “intensify the cohesion, the confidence, and, therefore, the power of an alreadyestablished social group". ${ }^{213}$ To what extent was the transcendental ideology of the Sultan-Caliph replaced by a Durkheimian doctrine of positivist progress? How did this relate to the state's attempts to bring the ayan classes under their infra-structural influence? What forms did the political conflict between the forces of centralisation and federalism take? How did this relate to the gradual disintegration of the Empire? Is it useful to regard the end of the Ottoman empire as a process of 'modernisation'?

Chapter Five will again deploy Mann's model to assess changes in the relationship between the economic elite and the Turkish state during the 1930s and following the Second World War. Significant issues to be addressed will include how this relationship was influenced by industrial development, increased urbanisation and the relaxation of Kemal's authoritarian state apparatus? What was the role of agricultural mechanisation? What factors brought about the end of the single-party state and how did this affect the role of the periphery? In what ways was social stratification altered? Why did the concept of a nonTuranian peripheral identity re-emerge in the gecekondu of the industrial cities? How did it become fused to the politics of the left? What forms did collective consciousness take? Did coherent classes emerge and, if so, how did they relate to the state? How relevant is Mann's account of class formation and perpetuation to the political economy of Turkey

${ }^{213}$ Mann, M. (1986) p. 24. 
during this period? Did growing regional and social wealth disparities, facilitate both the incentive and the social space for disaffection to be expressed outside the centralised control of the state?

Chapter Six will apply Mann's account of the relationship between domestic repression and political representation in order to analyse the rise of the Turkish military following the coup of 1960? How did the generals relate to the economic elite during the 1960s? What prompted the coup of 1971? How and why did organised social networks became increasingly militarised throughout the 1970s? Was the NSC's assumption of state control in 1980 a culmination of, or a response to, this process? How did the NSC attempt to institutionalise its position and how did the 1982 Constitution affect the state's relationship with civil society? Can Mann's elucidation of Western regime types help to better understand the system of government which has emerged in Turkey since the 1960 intervention? What was the nature of the link between the military and the state and what changes did this partnership go through during this period? What methods did decentralised groups, such as the $\mathrm{PKK}$, employ to institutionalise their position in the periphery? How have they sought to establish alternatives to the state's organisational maxim and to what extent are such organisations representative of non-statist opinion in civil society?

It will be seen from the sources cited in this chapter that the present state of knowledge and understanding regarding the development of the state in the Ottoman Empire/Turkish Republic is far from complete. These questions represent significant areas of disagreement within the current literature addressing both the theoretical and historical debate. The main body of this thesis will therefore focus on employing Michael Mann's methodology, the application of which to the specifics of historical analysis will be explored further in the following chapter, in order to resolve the issues outlined above. In doing so, this thesis will compare the Ottoman social trajectory to 
elements of Mann's elucidation of Western development - also discussed in the next chapter. 


\section{Chapter Two: Mann's Brief History of Time}

This chapter aims to give an account of Michael Mann's application of his theoretical model. In doing so, it will show how his largely abstract characterisation of social power, briefly set out in the previous chapter, is employed to explain both the emergence and necessity of the state and the permutable nature of its relationship with civil society. A central element of this is the essentially unilinear thread that Mann traces from Mesopotamian development to the refinement of imperial rule under Rome and its eventual subsidence in favour of the north-western European 'leading edge' of socioeconomic change during the medieval period and on to the appearance of modern bureaucratic nation-states. These key periods of power development make up the primary framework through which Mann's theoretical composition is applied. Having set out a rather condensed form of this encyclopaedic undertaking, the final section of this chapter will then highlight the critical debate that has surrounded Mann's work since the publication of the first volume of The Sources of Social Power in 1986. Particularly focused upon has been his treatment of the historical material, especially the role of Christianity in the development of feudal Europe, and both the diachronic approach that Mann favours and the overall validity of the macro-historical methodology.

\section{The Sources of Social Power}

In the two volumes of The Sources of Social Power Mann applies an historical perspective to his four-dimensional account of social power taking the reader from what he calls the 'beginning' to $1914 .^{1} \mathrm{He}$ argues that feudal states, reliant on the intensive, but non-

${ }^{1}$ Numerous shorter works which have accompanied the development of Mann's theoretical model will also be drawn upon. 
comprehensive and non-extensive, might of the military ${ }^{2}$ and governing through an often autonomous sub-structure of clerics and burghers tend to be low on both infra-structural and despotic power. An imperial state tends to wield high levels of often divinely legitimised despotic power through its own patrimonial government bodies, but, similarly constrained by the shortcomings of military force, it has a limited capacity to penetrate a frequently large and disparate territory and thus remains infra-structurally deficient. In contrast, modern bureaucratic democracies, in which the state's power is limited within certain institutions such as the media, the market and judiciary, usually have low despotic power and, through their information systems, immense infra-structural power.

For Mann, ideological power emerges from the need to impose categories of meaning onto our sensory perceptions, to formulate norms and understandings of how to interact and co-operate with other individuals and to develop, what he calls, "aesthetic/ritual practices" which cannot be fully tested by human experience. ${ }^{3}$ Thus, according to Mann's rubric, collective and distributive power can be exercised by organised minorities which institutionalise claims to meaning, or those that facilitate greater mutual trust within a social group or those that exploit the functionality of non-materialist practices such as poetry, dance and the plastic arts. Through universal infrastructures (such as markets, coinage and communications media), this may either transcend existing institutions of economic, military and political power by reinforcing/generating a 'sacred' form of authority or, alternatively, they may serve to "intensify the cohesion, the confidence, and, therefore, the [immanent $]$ power of an already-

2 Outside the immediate area of contact, Mann argues that a civilian population alters its behaviour little (apart from to offer tribute and recognise a leader's suzerainty) in response to a military presence (Mann, M., 1986, passim).

3 Mann, M. (1986) p. 22. Mann further clarifies his terms by writing, "in some formulations the terms 'ideology' and ideological power' contain two additional elements, that the knowledge purveyed is false and/or that it is a mere mask for material domination. I imply neither. Knowledge purveyed by an ideological power movement necessarily 'surpasses experience' (as Parsons puts it). It cannot be fully 
established social group". 4

Figure One: The Four Sources of Social Power ${ }^{5}$
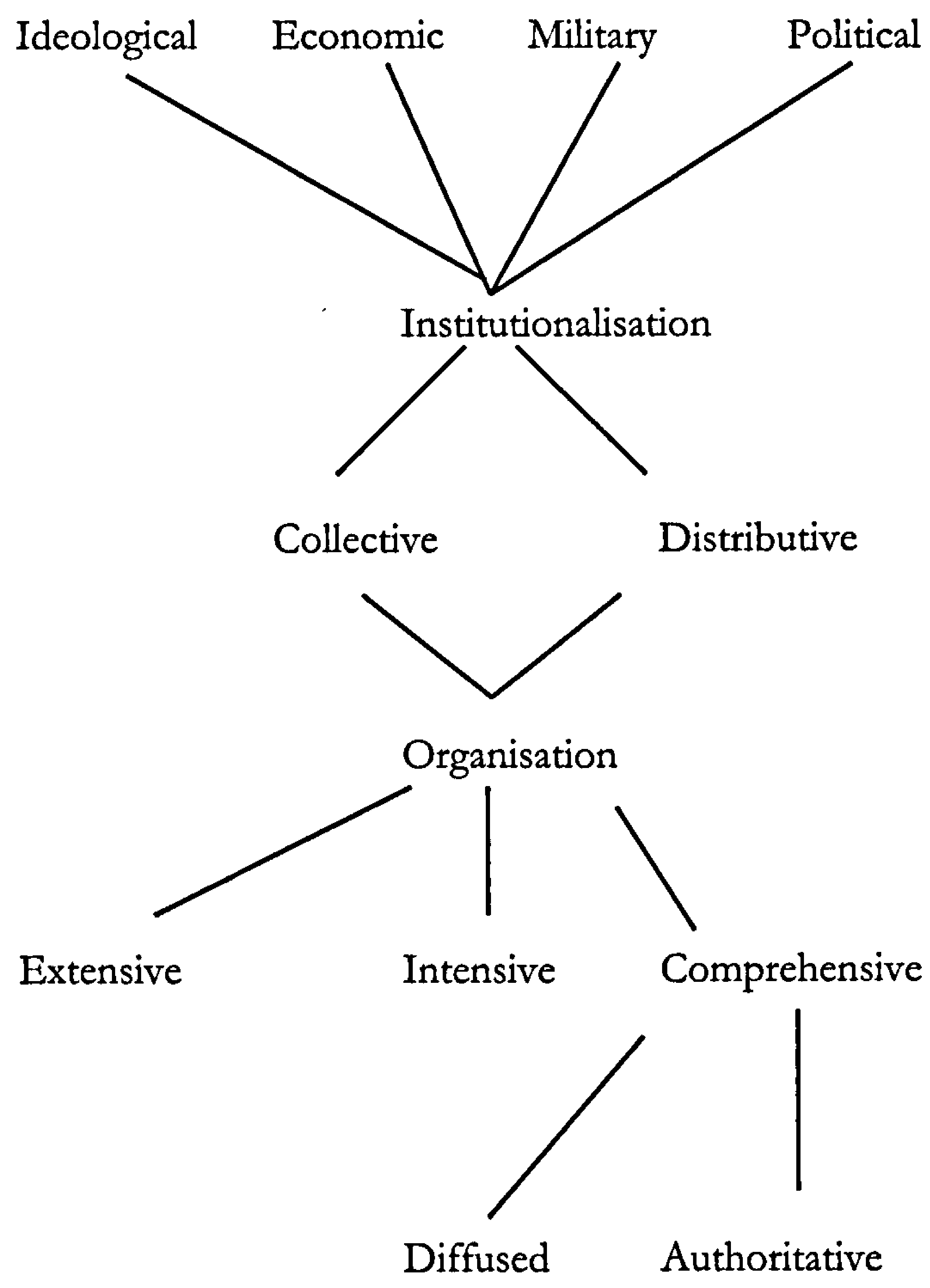

"Economic power derives from the satisfaction of subsistence needs through the social organisation of the extraction, transformation, distribution and consumption of the objects of nature". ${ }^{6}$ Each of these tasks has its own blend of collective and distributive

tested by experience, and therein lies its distinctive power to persuade and dominate. But it need not be false; if it is, it is less likely to spread" (p. 23).

${ }^{4}$ Ibid. pp. 23-24. My parenthesis.

5 This model, an adaptation of Mann (1986) passim, does not mean to suggest that the application of social power necessarily involves all elements shown above. It is doubtful that a social elite could, even in the most heavily authoritarian nation-state, employ such total power over its territory - see D. H. Wrong's comment on the nature of the concentration camp (1979) p. 28.

6 Ibid. p. 24. 
organisational characteristics and varying degrees of extensive, intensive and comprehensive power. Groupings around which, be they holders or subjects, are described by Mann as classes. For the 'ruling' class economic power can, in the case of internally organised landed classes for instance, be simply a question of "who shall be allowed to stand upon a given piece of land and to put things into it and take things from it". "Mann, however, argues that "in those cases where economic institutions have been authoritative, centralised and territorial they have either been subject to a higher level of territorial, central control by the state or they have acquired political function... and so become themselves 'mini-states"'. ${ }^{8}$ As outlined earlier, a despotic state without infra-structural reach can claim territoriality, but cannot enforce it. Therefore even the most authoritarian form of government must receive the endorsement of at least a section of its citizens. Central to this is the maintenance of the given relations of extraction, transformation, distribution and consumption of objects of nature through the support of the 'ruling' economic class.

For Mann, military power "derives from the necessity of organised physical defence and its usefulness for aggression". ' On the one hand it is "the bluntest instrument of human power", intensive and direct, on the other it has "a more extensive reach, of a negative, terroristic form" over large geographical and social spaces. ${ }^{10}$ The former relates to the militaristic control of everyday life and "requires such a high level of coercion, logistical back-up and surplus extraction that it is only practical within close communications to the armed forces"." Therefore it tends to remain in intensive pockets along logistical routes with little extensive penetration facilitating limited infrastructural reach and minimal territorial control. This is surrounded by a second radius of organised military power, "an extensive penumbra

\footnotetext{
7 Russell, B. (1938) p. 123.

${ }^{8}$ Mann, M. (1984) p. 199.

${ }^{9}$ Mann, M. (1986) p. 25.

${ }^{10}$ Ibid. p. 26.

$"$ Mann, M. (1984) p. 200.
} 
in which terrorised populations will not normally step beyond certain niceties of compliance, but whose behaviour cannot be positively controlled". ${ }^{12}$ The state can therefore utilise military power networks to impose its centralised authority over delimited territories and assert its institutionalised monopoly of the means of physical violence.

As outlined in the previous chapter, Mann's position is that the autonomy and power of a state, as the primary organisational form of political power in society, "derives from the usefulness of centralised, institutionalised, territorialised regulation of many aspects of social relations". ${ }^{13}$ The three alternative bases for social order, force, custom and exchange are more limited. Force cannot positively govern interaction for long, similarly customs cannot offer regulation in response to increasing complexity and to bargain over everything eventually becomes inefficient. ${ }^{14}$ Thus, social groups have, upon reaching various levels of complexity, established, as a generalised means of attaining goals, a set of normative rules of conduct representing the group as a whole or interest groups within it. As such, these can be institutionalised in a collective or distributive (or, more commonly, both simultaneously) manner by an organised minority or elite. In doing so "the state does not posses a distinctive means of power independent of, and analogous to, economic, military and ideological power. The means used by states are only a combination of these which are also the means of power used in all social relationships". ${ }^{15}$

From this necessity the autonomous power of the state has developed. Mann argues that, when organised by the state, political power networks are distinguishable by their centralised location, from which both collective and distributive power is exercised outwards, and their tendency, in domestic terms, to reinforce rather than

12 Mann, M. (1986) p. 26.

13 Ibid.

${ }^{14}$ Mann, M. (1984) p. 195.

${ }^{15}$ Ibid. p. 198. 
transcend territorial boundaries. In other words, "states can thus attain greater autonomous power when social life generates emergent possibilities for enhanced co-operation and exploitation of a centralised form over a delimited territorial area". ${ }^{16}$ When this occurs in neighbouring regions a multi-state system develops giving rise to a second organisational form of political power, 'geopolitical diplomacy'. Although no state has been able to completely control all social interaction across its boundaries, thus leaving some social power diffused and decentralised, an increase in territorial centralisation tends to precipitate additional "geopolitical activity, both peaceful and warlike". ${ }^{17}$

For Mann, this process "emerged as a result of the impetus given by alluvial agriculture to diverse, overlapping networks of social interaction present in the region surrounding it" and generated a greater need for authoritative regulation eventually "embodying permanent coercive power". ${ }^{18}$ In other words, the social need for flood prevention and control in hydraulic agricultural areas of the Euphrates basin during the third millennium BC provided a more "powerful impetus toward larger political units than the kin group or village". ${ }^{19}$ In this region, in contrast to the Nile Valley where, as Mann puts it, people were entirely "caged" by an "absolute boundary" of the desert or in Europe where a more even ecology led to a more continuous distribution of population, a "two-level, segmental, semicaged" pattern of settlement emerged. ${ }^{20}$ As alluvial agriculture bettered the yield of rain-watered systems, economic power also became centralised and structured the relationship between the settled urban core and the pastoralists of the periphery. "It enabled those who controlled the land to mobilise a disproportionate amount of collective social power and to turn it into distributive power used

${ }^{16}$ Mann, M. (1986) p. 31.

17 Ibid. p. 522.

${ }^{18}$ Mann, M. (1986) p. 77

${ }^{19}$ Ibid. p. 86.

20 Ibid. p. 81. 
against others".21 Thus, for Mann, neither the state nor social stratification originated from within existing societies, but rather because "(1) out of the loose, overlapping social networks of prehistory emerged one network, alluvial agriculture, that was unusually caged and (2) in its interactions with several peripheral networks, further caging mechanisms appeared that constrained them all toward greater involvement on two levels of power relations, those within the local state and those within the broader civilisation". 22

\section{From City-State to Empire}

According to $T$ Jacobsen, these early administrative requirements were first vested in Sumerian temple legislatures probably made up of large oligarchies of patriarchal family representatives in around 3000 $\mathrm{BC} .^{23} \mathrm{P}$ Wheatley, cited by Mann, supports this, arguing that it was the ceremonial temple complex, not the market or the fortress, that emerged first as an urban institution. Each city-state is thought to have possessed its own deity providing the city with a "focus of loyalty" and connecting it to a broader pantheon of common Sumerian gods. ${ }^{24}$ In their studies of state evolution in the New World, Coe and Keatinge draw attention to the importance of this shared identity as a means of integrating a territory broader than that which a purely politically-organised state could manage thereby adding credence to Mann's assertion that the 'transcendent' organisation of ideological power was likely to have regulated the city-states both religiously and diplomatically. ${ }^{25}$ Thus these temples simultaneously exerted a diffused, extensive and collective power over the contact between both alluvial and peripheral society offering ideologicallylegitimised approaches to a diverse range of issues aimed at

\footnotetext{
${ }^{21}$ Ibid. p. 83.

22 Ibid. p. 127.

${ }^{23}$ Jacobsen, T. (1970) Ch. 9.

${ }^{24}$ Mann, M (1986) p. 91.

${ }^{25}$ Coe, M. (1982) passim \& Keatinge, R. (1982) passim, cited in ibid. p. 76.
} 
maintaining order and unity over a large and disparate region. ${ }^{26}$

In contrast, Mann suggests that economic power groupings were 'caged' by the ecological differences of managed alluvial flooding and rain-watering and by the natural resources available to settled and pastoral populations. This led to greater economic surpluses in some parts of the region than others offering increased employment opportunities, urbanisation and the growth of centralisation. Trade between the alluvial 'core' and the wider region centred on particular communication routes, such as rivers and provincial market towns, possession of which, usually by groups associated with the core, offered enhanced economic opportunities. These routes also served as re-exportation lines for the manufactured goods predominantly produced in the core which were increasingly traded for labour and raw materials, such as minerals and hide. In this way the core, Mann writes, gained a disproportionate level of "control over a relatively generalised means of exchange, over 'prestige goods' for displaying status, and over the production of tools and weapons". ${ }^{27}$

As the exchange of a growing agricultural and manufacturing surplus increased, defence of these trade routes became more important, particularly for the dominant economic groups of the core. Although Mann resists the emphasis on militarism favoured by some writers, arguing that it was the development of political-economic differences supported by ideological organisation and ecological accident rather than the conquest of one kin-group by another that led to the beginnings of social stratification, he does acknowledge that the organisation of military power helps to explain "further state development" ${ }^{28}$ City-states constructed fortified walls and kings with despotic pretensions emerged who, as both Jacobsen and Mann conjecture, may have been elected by the temple oligarchy for

${ }^{26}$ Mann estimates that up to half a million people may have described themselves as 'Sumerian'.

${ }^{27}$ Mann, M. (1986) p. 125.

28 Ibid. p. 99. 
combatant functions in time of war. Thus the organisation of expensive military formations such as fortifications, infantry and animal haulage favoured the king over the temple and the centralising state. As a result, and because defeated social elements could not escape their environmental cage and so became a subjugated class in an enlarged society, authoritative, despotic power increased and broader, diffused influences weakened.

As Mann notes, however, in the absence of a standing army or military elite it was difficult to convert this temporary authority into permanent coercive force. Although a few kings did institutionalise their position by founding dynasties, most were not able to keep the state's resources to themselves as increased economic centralisation tended to favour the leading families of the core, many of whom also employed large mercenary armies. The economic elite's legitimacy increased in the temple oligarchy as trade developed and this enabled them to compete with the kings (none of whom claimed divinity) and the pantheon's priests. The territory the temple needed to militarily and diplomatically regulate, in the absence of an international currency ascribing an agreed commodity value, also increased necessitating the devolution of infra-structural power to provincial merchant families. Mann suggests that through this mechanism, their superior military resources and their greater agricultural and manufacturing efficiency, city-states were initially able to repress opportunist challenges to their supply lines and protect their colonies and staging posts. As these became more extended, however, it became impossible to maintain political power over any length of time. Soldiers and merchants sent out to maintain these outposts soon merged with local people and developed autonomous networks of interaction culminating in Sargon of Akkad's successful rebellion in around $2310 \mathrm{BC}$ and the establishment of what Mann calls "the first empire of domination". 29 The dynamics of this new system of governance remained, as Mann continues, "one of the dominant 
social forms for three thousand years in the Near East and Europe, and even longer in East Asia". ${ }^{30}$

Sargon probably came from the Semitic people of northern Sumeria, an area of mixed agriculture and pasture lands. From this marcher base he conquered all of the Sumerian states in thirty-four campaigns, stretching from the Persian Gulf to Anatolia. Generally these took the form of an approach to a city-state and, possibly following a skirmish in which his forces' clear superiority was demonstrated, making the inhabitants an offer they could not refuse. This method of "coercive negotiation" was, Mann states, often supported by the encouragement of "piecemeal treachery" on the part of disaffected elements of the city's defence administration. ${ }^{31}$ Surrender, settled quickly so that Sargon's forces could move on to the next source of surplies, was far more common than full-scale confrontation and generally resulted in a loss of stored property and the city walls (and perhaps a change of leadership) rather than complete annihilation. Thus the marchers relied as much on their diplomatic acumen as their military strength. That said, it is probably true that, with the decline of the oligarchic polity of Sumer, there was an increase in the despotic power of the state, later institutionalised by Sargon's grandson, Naram-Sin, whose claim to divinity provided a decentralised aristocracy with a legitimising genealogical connection.

Nevertheless, having subjugated an extended territory, Sargon's forces found that political power, necessary to administer their conquests, involved dispersing some of their coercive force and thus jeopardising their military advantage. Mann, building on Owen Lattimore's triadic model of imperial power, ${ }^{32}$ identifies four possible "strategies for

${ }^{29}$ Mann, M. (1986) Ch. 5.

${ }^{30}$ Ibid. p. 131. As such, the Akkadian system, later refined through Rome's legionary economy, will provide the analytical basis for the study of imperial power in this thesis.

31 Ibid. p. 141.

${ }^{32}$ Lattimore, O. (1962) passim. 
ameliorating this and for developing genuine imperial domination". ${ }^{33}$ The first of which was to rule through clients, whom Mann calls "conquered native elites". ${ }^{34}$ This was particularly effective with subjects possessing minimal material and organisational resources especially when supported by increased tribute, elite re-organisation and occasional punitive raids. Diffused political and ideological power could also be applied by encouraging or forcing the elite to surrender children to be 'educated' within the imperial core and then returning them to act as peripheral agents. Sargon, according to Mann, employed this relatively low-cost method, despite its disadvantage of leaving an autonomous local elite to develop its own resources or be seduced by an internal or external challenge, by appointing Akkadians, of various lineage, to the courts of local kings.

A second strategy identified by Mann was to administer conquests directly through the army. Although it involved the greater expense of eliminating more of the indigent elite and extracting a greater tribute from local agriculturists to support such an infra-structural presence, as well as higher salary costs for the professional soldiers employed to oversee these policies, it was used to secure key areas of the core and parts of the periphery thought to be of high geopolitical value. The authority of the commander could be institutionalised by his access to the spoils of the recent conflict, but the distribution of such resources, particularly land, among his lieutenants was inclined to decentralise military power "embedding the soldiers in 'civil society' and giving them material resources whose enjoyment was now independent of the army or the state". 35 This tended to develop an autonomous, hereditary and land-owning class united only by a shared fear of the subjugated masses rebelling.

Indeed, Mann suggests that these early empires of domination, like

\footnotetext{
${ }^{33}$ Mann, M. (1986) p. 143.

${ }^{34}$ Ibid.

${ }^{35}$ Ibid. p. 144.
} 
the city-states before them, often relied entirely on local aristocrats for what little infra-structure they did posses. "So in practice," he continues, "empires were territorially federal... looser, more decentralised, more prone to fission than the state's own ideology usually claimed". ${ }^{36}$ For Weber this form of patrimonial organisation, stubbornly imbued in Eastern civilisation, explains why these regions did not follow the rational and activist spirit of acquisition and production apparent in the developmental patterns that eventually emerged in Europe. ${ }^{37}$ Mann essentially agrees with this account, but adds, after Eisenstadt, ${ }^{38}$ that "a state cannot be merely aristocratic. Genealogical claims are inherently particularistic; they are the antithesis of centrality and of the state". ${ }^{39}$ Thus, in contrast to Weber's claim that decentralised structures must be in place before dynamism can occur, change is determined by a dialectic between the centralising tendencies of the state and the decentralising effects inherent in political rule; a tension evident, for Mann, in the history of Near-Eastern, Mediterranean and Western societies. The first empires of domination, low on infrastructure and high on despotism, were therefore essentially systems "of federal domination by a king or emperor through provincial, marcher, and even 'foreign' rulers and elites" and, as such, were reliant more upon leadership qualities than any institutionalised political structures. ${ }^{40}$

Figure Two: Strategies of Imperial Domination

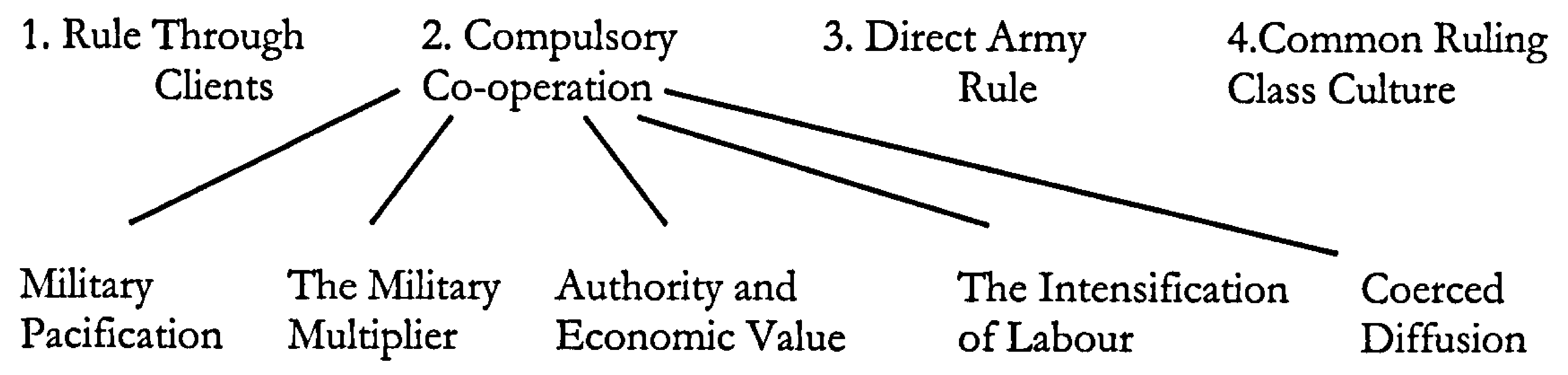

\footnotetext{
${ }^{36}$ Ibid. p. 170.

37 Weber, M. (1968) pp 1006-1069.

${ }^{38}$ Eisenstadt, S. (1969) passim.

39 Mann, M. (1986) p. 170.

${ }^{40} \mathrm{Ibid}$. p. 174 , his italics.
} 
The third of Mann's strategies of imperial domination is what Herbert Spencer calls "compulsory co-operation". As such, social stratification and the mode of production tend to be subservient to the military. "The industrial part of the society", Spencer argued, "continues to be essentially a permanent commissariat existing solely to supply the needs of the governmental-military structures, and having left over for itself only enough for bare maintenance". ${ }^{41}$ For Mann, this 'militant society' has five aspects. ${ }^{42}$ Military pacification is necessitated by the need to regulate ownership and value and to repel banditry as specialisation within the Akkadian empire produced less selfsufficiency and greater trade-dependency. It is also required when famine, disease etc produce desperate masses who must be quelled through a combination of force and economic redistribution. Secondly, the military multiplier ensures that the army's consumption need for staples maintains demand, stimulated production and improved economic infrastructures such as road and river transport networks. Thirdly, in correlating authority and economic value, "the redistributive state could often, perhaps even usually, assign exchange value more speedily, efficiently, and apparently justly than could a process based on reciprocity, that is, a market". ${ }^{43}$ Fourthly, the intensification of labour reflects the usefulness of coercion in increasing productivity from indentured or, in the relatively few areas where social stratification and private property were stable, hired labour.

Fifthly, and in contrast to the first four, which are based on the authoritative bridging of local differences, coerced diffusion, Mann contends, tends to break down these "particularisms" through collective power. Most notable in the Akkadian-Sumerian example was the fusion of pictographic and syllabic literacy into an

\footnotetext{
${ }^{41}$ Spencer, H. (1969) p. 121.

42 These are discussed in Mann, M. (1986) pp 146-155.

43 Ibid. p. 150.
} 
international language of trade and diplomacy which extended the diffused ideological power of the empire and reduced local identities in favour of the broader influence of the state. "Literacy was restricted to the bureaucracy, stabilised its systems of justice and communications and so provided infra-structural support to a state despotism". ${ }^{44}$ So, for Mann, the economic development which compulsory co-operation facilitated "did not depend on the direct interdependence or exchanges of the mass of the producers or of the middlemen, but on the provision of certain uniform and repressive services by a military state". ${ }^{45}$ It also led to greater social stratification as the relatively small (Mann estimates that, with direct beneficiaries, they may have amounted to no more than 5-10 per cent of the population) elite increased their standard of living. Economically, however, they were not independent of the state's centralising 'repression as benevolence'. "In other words," Mann writes, "the ruling elite, created by military organisation, but whose political tendency was to fragment into decentralised landowners, depended on a central state through the economy".46

Ideologically too, the state increased its power by bringing Mesopotamian religion closer to its centralised control. Mann points to evidence which suggests that there was a decline in the Sumerian emphases on transcendentalism in favour of a new pragmatism. As such, "it was immanent, grappling intellectually, morally, and aesthetically with given power relations, and in its success strengthening them". ${ }^{47}$ This state-determined religion aimed to persuade the aristocracy and military elite that they were participants in a common culture governed by universally normative regulations. In Mesopotamian imperial history, the alliance between state and religion culminated in the dominance of the Assyrians around 12001000 BC where, despite occasional eruptions of unofficial 
transcendentalist organisation, it was instrumental in the creation and sustainability of a "common ruling class culture", the fourth of Mann's strategies of imperial domination. It was, however, in Rome's 700 year administration of much of Europe that the promotion of this perceived commonality reached authoritative levels leading to the empire of domination becoming what Mann describes as "a true territorial empire". ${ }^{48}$ Ideological integration was facilitated by infrastructural improvements in communication leading to the prevalence of Latin literacy throughout the upper echelons of society. Although it was taught to other classes as well, it did not enter common verbal usage and thus remained a lingua franca restricted to the generals, judges, landed nobles, priests and senators. As it prevailed over all the western provinces and, mixed with some Greek, over much of the east, this cultural cohesion allowed the process of imperial accession to include provincial governors from all parts of the empire. "Thus there emerged a universal ruling class - extensive, monopolising land and the labour of others, politically organised and culturally conscious of itself'. ${ }^{49}$

\section{From Feudal-State to Nation-State}

Perhaps already weakened by internal degeneration and population decline, the Roman empire was severely shaken by barbarian encroachment across its frontiers in the late second century $A D$. Emperor Diocletian's reforms (AD 284-305) doubled the size of the army and greatly increased the burden of taxation which the ruling classes attempted to pass onto the peasantry. Under such pressure, in an already near-subsistence economy, land went out of cultivation and previously free families placed themselves under the protection of local land-owners in order to avoid the imperial tax-collector. Thus "the emergence of the 'semi-free' feudal serf (the colonus) holding his

\footnotetext{
48 Ibid. p. 250, his italics.

49 Ibid. p. 270 , his italics. Mann continues by commenting that "a century after conquest, local ruling elites were almost indistinguishable from each other in their languages, beliefs and customs" (ibid. p. 311).
} 
land as a favour from his lord began to create a 'universal class' within the territories of the western empire even before its collapse". ${ }^{50}$ Moreover, as insurgent incursions made trade routes more insecure inter-provincial trade declined and the landed classes began to increase their independence by improving their self-sufficiency. This led to what Mann identifies as a "three-way power stand-off" between the state, the ruling classes and the people at a time when only a closing of this social gap could have protected the empire against the invaders. ${ }^{51}$

So, as the influence of Rome declined, particularly from the late fourth century onwards, its ability to maintain ideological links with this ruling class lessened. As a result, the elites, particularly on the imperial periphery, further decentralised relying on separate agreements with the barbarian invaders rather than the no-longer unquestionable power of Rome and what Mann calls its "legionary economy". ${ }^{52}$ Thus in many regions political structures took on the character of the small, loosely federated kingdoms and warrior aristocracies typical of the invaders, while retaining adapted forms of Roman ideological and economic networks - "spheres of continuity" as Mann puts it. ${ }^{53}$ These revolved around Christianity which had spread rapidly through the empire's strongly developed literacy links as a means of further securing institutionalised elite loyalty providing, in Mann's terms, an ecumene or a universal fellowship. In other words, "giving morale to the ruling classes of the empire, giving them common access to the stock of cultural knowledge and reinforcing their cultural solidarity". ${ }^{54}$ Once Roman military and economic hegemony had weakened, however, proselytising Christianity, often as a means of maintaining social statuses in the new European order, became, like other functions of the ruling classes, increasingly

${ }^{50}$ Mann, M. (1977) p. 282, his parenthesis.

51 Mann, M. (1986) p. 295

52 Ibid. Ch. 9.

53 Ibid. p. 336.

${ }^{54}$ Ibid. p. 314. His italics. 
decentralised. The long-established monastic schools were invigorated by the provincial senator turned bishop, important leaders such as Charlemagne and Alfred allied their causes with the Church's mission and Christendom became, in Mann's view, "the leading agent of translocal extensive social organisation". ${ }^{55}$ For the empire's new barbarian settlers, mainly confined within intensive local relationships, the Church offered an extensive literacy network beyond their oral traditions, a system of morality that could regulate trade and a "monastic-episcopal economy" of feudal manors modelled on the late Roman villa. ${ }^{56}$ In this way, an embryonic perception of group identity emerged - or, what Mann calls, the beginnings of 'religious protonationalism'.

Like the Roman state, however, the papal infra-structure was extremely extensive, covering over a million square kilometres by the year 1000, and thus limited in its intensity. The bishop was one of a number of ruling titles tied to vassals and subordinates through military contract. The political unit remained comparatively small as any larger consolidated groups tended to fragment once a territorial objective had been secured by the knight and fortress combination. This form of political organisation, structured by what Mann describes as "an agglomeration of largely autonomous households", offered the ruler only indirect access, apart from those labourers directly tied to his land, to his citizens. ${ }^{57}$ The state's infra-structural powers were particularly limited in systems in which vassals owed allegiance to a number of competing superiors such as neighbouring princes, parishes or landed families. In many cases political function was, according to Mann, so decentralised and short on territoriality that it was only during times of war that any influence could be

\footnotetext{
55 Ibid. p. 337.

56 Ibid. He continues "in its retreat from the Roman world, it [the church] had created a monastic microcosm of Roman extensivity - a network of monasteries, each with its own economy, but not self-sufficient, trading with other monasteries, with the estates of bishops, and with secular estates and manors" (ibid.). My parenthesis.

57 Ibid. p. 391.
} 
exerted over the populace by the ruler and a 'state' be said to exist. Even then, though, this did not extend across authoritative scopes such as the divide between Church and manorial court processes.

For Mann, the need for organised defence and the superiority of the fortress cavalryman over peasant infantry, even during peace time, led to a more pronounced level of social stratification. In addition, economic stimulation resulted from an increased demand for statusrelated goods, to denote the position of the owner, and a large-scale castle building programme. Consequent population rises during the thirteenth century increased agricultural production which, in turn, led to greater pressures on arable land bettering the lords' managerial position. This allowed them to bring the peasantry closer to the power of the manor and become, in Marx's words "the master of the process of production and of the entire process of social life"; in effect, striving towards an exclusivity of land possession and the beginnings of a capitalist economy. ${ }^{58}$ Famines and plagues during the fourteenth century, however, which made labour scarce and land more plentiful brought possibilities of capital accumulation for the peasantry as they began to acquire surpluses and use them as payment in place of further service. Some were able to hire the labour of others as commodities to work their land leading, Mann argues, to a parallel route to exclusive private property and capitalism.

As what Mann calls these 'circuits of praxis' developed, they tended to generate "technical problems involving more complex economic relations between strangers to which the church was more marginal". ${ }^{59}$ No longer could Christendom's normative and pacifying effects be relied upon to regulate trade with north Africa and beyond. Instead innovations such as contractual regulations, insurance loans,

\footnotetext{
${ }^{58}$ Cited in ibid. p.410. Mann continues, "For example, the water mill... tended to be exploited as a feudal monopoly. Peasants were forced to take their grain to the lord's mill, as they were to use his ovens, draw his water, burn his wood, and use his winepress" (ibid.).

59 Ibid. p. 437.
} 
exchange bills and maritime law emerged through a rediscovery of Roman legislation and served to further reduce transaction costs and increase the efficiency of production. This, Mann suggests, was matched by a rise in the state's use of literacy, evident in Henry II's use of writs to his provincial agents and written guidance on estate management. Developments in communication became institutionalised in the early universities in Oxford, Paris and Bologna and increasingly diffused by technical innovations such as the use of paper, which was cheaper and lighter than parchment, in the early fourteenth century. Thus, originally confined within the state as a means of solidifying imperial despotism, literacy had now spread and was largely being used collectively by groups in civil society as a basis for, what Mann terms, 'commercial-statist proto-nationalism'.

Infra-structurally, too, the state was, for Mann, also able to benefit from these developments. Although feudal states lacked the formal despotic powers of the Roman rulers, few monarchs claimed divinity or legislated by entirely independent decree, their infra-structural challenges were less daunting. The English Exchequer, for instance, regulating an area less than a twentieth that of Rome's, was able to insist on county sheriffs delivering their accounts for scrutiny twice a year and even had the administrative control and communications infra-structure to move from Westminster to York in 1322. As collective power was vested in a monarch and council, later a monarch in parliament, government was enacted "by the consent and, through the co-ordination of the involved power groupings; ... [it also] presupposed a settled, 'universal', territorial state more than it did the particularistic feudal relations of vassals to their lords". ${ }^{60}$ Since within this political structure local notables had limited powers of interpretation and little contact with each other, state agents could, by holding regular policy meetings at a local level, territorially co-ordinate these provincial power holders and solidify their loyalty to the crown with dynastic ties. Mann does not claim, however, that tensions did 
not remain between monarch and eminent locals, but rather that the system "was strong in historical terms in co-ordinating its territories and subjects and in concentrating the resources of its core home counties', even if it was weak in powers over them". ${ }^{1}$ Thus the monarchic state, having formed a co-ordinated and extensive alliance with the capitalist magnate, remained on two levels of territory or, in other words, territorially federal.

According to Mann, a number of factors brought this "segmentation" of state function to an end and led to what he calls the "co-ordinating state" being replaced by the "organic state". ${ }^{62}$ Foremost, as part of the state's geopolitical function, was the increase in the cost of warfare. Garrison and equipment expenditure, particularly keeping up with fire-arm technology, had been rising throughout the medieval period, occasionally exacerbated by labour shortages. From around 1540 onwards, however, it was the development of new defensive formations, such as the reintroduction of infantry lines now armed with muskets and protected by land-workings, which prolonged campaigns and necessitated greater investment. Furthermore, these methods required more training than mobile battalions and more men to dig defences further increasing the expense. Naval costs also rose exponentially as developments in cannonry obliged monarchs to refit and retrain their fleets. Mann estimates that English state revenue, for instance, was increased from $£ 126,500$ per annum in 1505 to $£^{2,066}$ 900 in 1688, much of which was due to the costs of warfare. "All these changes", he concludes, "led to a greater role for capitalintensive supplies and, therefore, for centralised, orderly administration and capital accounting which could concentrate the resources of a territory. The changes enhanced territorially centralised power (the state) but also enhanced the diffusion of commodity

${ }^{60}$ Mann, M. (1986) p. 445. My parenthesis.

${ }^{61}$ Ibid.

62 Ibid. Ch. 12 \& 13.

${ }^{63}$ Ibid. p 451 . Before this, from 1166 to 1452 , revenue had only increased from $£ 12,200$ to $£^{54,400}$ (ibid. p. 425 ). 
forms within that territory (i.e. capitalism). ...The link between capitalism and the state was growing". ${ }^{64}$

Although these developments did not include any change to the limitations on mobility and supply logistics of army movement (ground forces were still reliant on three days of plunder for every nine days of marching), they did mean, Mann argues, that smaller states, who could not finance large-scale siege warfare, would tend to give way to bigger, more centralised administrations. Now that monarchs could batter down the fortresses of their recalcitrant gentry, greater infra-structural reach into civil society was possible. States did, however, continue to require ever-increasing amounts of their nobility's wealth and this was reflected in the gradual shift towards broader representation of these peripheral interests as the conciliar system of governance slowly gave way to constitutional parliamentarianism. So that their still considerable ability to resist state intrusion, particularly tax-collection, could be better managed, these burghers and nobles were drawn closer into both military and civil state offices. The 'court' thus became a mechanism for distributing state duties and royal favours through a system of client-patron relationships. "As a collectivity, a class, extensive and political, not any longer a set of family lineages", the bishops, lords, merchants, county gentleman and others now began, in Mann's view, to "control the nation's administration, army, polity, judiciary, and church. ...The[ir] ideology was universal and organic. The interdependence of crown and propertied classes was now so close that ideology could soon also be reality". 65

The hitherto extensive and unifying Christian ecumene was, according to Mann, also undergoing change. The church's emphasis on doctrinal cosmology, far removed from Christ's original message had, by the fifteenth century, become an essential part of its authority.

${ }^{64}$ Ibid. p. 454. His parentheses.

${ }^{65}$ Ibid. 463. My parenthesis. 
Having been unintentionally challenged by Galileo and others, this was broken down in favour of a revived interest in humanist learning and individual rationality which, Mann asserts, was too diffused for Rome to influence. Similarly, the new market systems of commercial statism further conflicted with, and exerted a decentralising influence over, the extensiveness and authority of papal power by legitimising status according to the value of labour and property and highlighting the tension between Christian duty and the capitalist imperative of reinvestment. Thus neither the transcendental sense of meaning nor the use of Latin was of much help to the entrepreneurial and artisan classes, making them, in Mann's view, likely to "seek a new modus vivendi within the church or break out in the direction of a more individual form of salvation". 66 The rise in power of the more economically developed European north-west also threatened the ecumene stretching Rome's geopolitical links as its military capacity developed. In all, Mann concludes, it was no surprise that Luther's 1517 petition was immediately taken up by the Saxon rulers, important opponents of the Austrian court, making Protestantism a political as well as a theological dispute from the outset.

As a result, in several of the Protestant countries and, to a lesser extent, in some Catholic ones, religion became absorbed into "the organic unity of the national state". ${ }^{67}$ The state used previously ecumenical networks to spread their vernacular horizontally through the gentry and vertically as far as the artisan classes. In contrast to Chaucer and his contemporaries, Shakespeare, for example, only needed to write in one language leaving others (Gaelic for instance) to the periphery. Once divided and polarised by the bloodshed of the Wars of Religion the extensiveness of the Church's ecumene, although still essentially trans-national, became demarcated by geopolitical diplomacy based on shared capitalist goals normatively regulated by states. Christianity, remaining strongly influential in individual, family 
and neighbourly relations, thus became, by the end of the seventeenth century, primarily a decentralising force of the periphery, as "commercial capitalism and military states displaced churches as the principal communicator of messages between the intensive and the most extensive levels of power". ${ }^{68}$

For Mann an example of the rise in the extensiveness of this capitalist and national state is the increase in value of foreign trade during the eighteenth century. He estimates that, in Britain for instance, this grew from 12 million pounds out of an overall national income of 50 million pounds in 1700 (England and Wales) to 70 million pounds out of national income of 232 million in 1801 (Great Britain) ${ }^{69}$ Initially wool and cloth made up a significant proportion of this, but, by the end of the century, this was giving way to re-exports of colonial products such as sugar and tobacco. Although the trading patterns of different states varied greatly, "the general trend was that most of the growth of foreign trade was confined within its own sphere of influence, albeit now crossing the globe". ${ }^{70}$ Within these national economies few restrictions impeded trade, coins identifying the sphere of influence's monarch were exchanged without significant class or status barriers and became the method of 'commoditising' property as technical innovations and the 'invisible hand' of entrepreneurial investment gained force.

In most states these forces did not combine to empower one single capitalist class, instead Mann uses the term nation ("meaning those who had a stake (i.e., property) in the emerging national state') to denote three "broadly capitalist class actors" as ideal types. ${ }^{71}$ Firstly, the 'old regime', consisting of the monarch, court, state-recognised church and various aristocratic and merchant oligarchies, possessed substantial amounts of property, acted 'capitalistically' and, although

${ }^{68}$ Ibid. p. 228.

${ }^{69}$ Mann, M. (1986) p. 492.

70 Ibid. p. 493.

${ }^{71}$ Mann, M. (1993) p. 96. His parenthesis. 
as a group they were by no means homogenous, exerted extensive influence over functionaries and broader civil groups alike. Secondly, the rising 'petite bourgeoisie' of urban capitalists including artisans, teachers and journalists who, mostly non-enfranchised, were largely excluded from the state and often opposed to its illiberal tendencies. Thirdly, 'peasant farmers' who owned, or possessed a secure tenancy over, their farms and used predominantly family labour. By around 1830, however, Mann claims that a 'capitalist class' had begun to emerge from the amalgamation of the old regime and the upper petite bourgeoisie and by 1870 "the powers of the 'invisible hand', court, church, landed aristocracy, financial institutions, industrial corporations, and the national state were", he submits, "largely centred in its hands". ${ }^{72}$ The remaining petite bourgeoisie, along with the professional classes and careerists, formed what he terms a 'middle class' while the artisans became proletarianised and the peasant farmers retained their class identity and their social immobility.

A part of the differentiation of these ideal types, for Mann, lay in the spread of literacy and its associated ideological power. The sale of newspapers and periodicals had grown tenfold during the eighteenth century with virtually all social gathering points, from wig-makers to waiting-rooms, stocking a selection. Indeed, these networks became centres of bourgeois resistance to the growth in state militarism. The increasing levels of state extraction which early nineteenth century geopolitical competition brought reinforced civil identities in, what Mann terms, the beginnings of the "militarist phase of modern nationalism'. Nevertheless, the greater 'national' identity of most nineteenth century states tended to feature alongside a range of classorientated, or religious, dissent in the majority of publications. While commonly promoting alternative, 'transcendental' images of social organisation, few, in Britain for instance, challenged what Mann calls

72 Ibid. p. 97. 
the "Protestant constitution" of the old regime. ${ }^{73}$ The petite bourgeoisie, he argues, generally demanded change (an expansion of suffrage, a reduction in political patronage, etc.) from within the confines of state institutions, such as parliament and the courts, and in a proliferation of critical, but essentially statist, publications. So, in essence, Mann concludes, the national state continued to be "simultaneously centralised actors and places where civil society relations are co-ordinated". ${ }^{74}$

Military power during the nineteenth century was, Mann asserts, similarly dual in nature. Relations between officers and men were increasingly a reflection of the narrowing social stratification of society generally. By 1804, Mann notes, only three of Napoleon's eighteen marshals were from the nobility and over half the officers recruited from the ranks; a situation the restored Bourbon monarchy later found impossible to fully reverse. ${ }^{75}$ The bourgeois nature of European armies, supported by campaigns which had demonstrated the improved morale of men and officers who share the same privations, rationalised coercive discipline into an even-handed book of regulation making it more humanitarian and less based on corporal punishment. The enlisting of mercenaries declined as the armed forces were imbued with the concept of national statehood. As such, welfare provisions for soldiers (both officers and men), intended to buy their loyalty, were introduced, wages (now paid on time) were kept abreast of civilian occupations and long-service military professionals at all levels were used to train the expanding ranks of short-term conscript reservists.

Nevertheless, in keeping with his dialectical characterisation of social power, Mann argues that improvements in the upper echelon's infrastructural capacity were simultaneously "tightening military

73 Ibid. p. 106.

74 Ibid. p. 109, his italics.

75 Ibid. p. 426. 
organisation over their soldiers, reducing their ability to identify themselves as citizens or as members of classes". ${ }^{76}$ Administrative innovations in the handling of maps, communications and timetables, particularly by the Germans, enabled commanders to co-ordinate soldiers' lives much more thoroughly and to nurture great camaraderie in their units. ${ }^{77}$ This was further supported by ensuring that recruitment was predominantly centred around the least developed and most conservative agrarian regions of the state. Territorially organised, already accustomed to authoritative power and motivated by agricultural labour surpluses, these units were, in Mann's view, 'segmentally' organised into the military hierarchy in a way that restricted their contact with other units and denied both men and their officers access to command strategy. Thus, despite high levels of hardship, as evidenced by the First World War, any organised alternatives to compliance were made extremely problematic.

More broadly, states, requiring greater social discipline to improve industrial efficiency and output, were able to use short-term conscription to enshrine in the minds of their people, what William McNeill describes as, the "primacy of the command principle". ${ }^{78}$ This collaboration between old regime, capital and state did not, however, alter what Mann considers to be the military's proclivity for conservative self-absorption. He suggests that its focus on technocratic outcomes, fuelled by the innovations of the industrial revolution, ensured that, despite being recruited from the same social backgrounds as the diplomatic corps, the military high command remained resistant to alliance building and non-combatant solutions generally. Industrial output and infra-structure, in facilitating the rapid deployment of very large quantities of resources at the battlefield, also necessitated greater logistical secrecy and blurred the distinction

\footnotetext{
76 Ibid. p. 428.

${ }^{77}$ Mann points to declining desertion rates, exemplified by the Confederate Army in the American Civil War (ibid. p. 429).
} 
between aggression and preparedness, further enhancing military insularity and autonomy.

The increasing reliance on reservist conscripts during the nineteenth century saw a decline in the proportion of professional soldiers employed by the state. In Austria-Hungary, for instance, the figure, cited by Mann, dropped from 2.38 per cent of the population as a whole in 1810 to 0.86 per cent in 1910 with comparable figures recorded in Prussia-Germany, Great Britain and France. ${ }^{79}$ It was, however, quite the opposite in the case of civilian employees. Again in Austria-Hungary, Mann finds that the proportion of the population employed at all state levels rose from 0.12 to 3.15 over the same period. ${ }^{80}$ Much of this expansion included the petite bourgeoisie and, as the state institutionalised citizenship, was accompanied by national bureaucratisation. Industrialisation, Mann argues, enhanced nations' economic integration and developed corporate models of meritocracy leading to a coalition of the professional classes and liberal capitalists aimed at promoting notions of 'national efficiency'. Embracing the new administrative and organisational sciences the state increased its infra-structure and extensiveness and provided some degree of internal cohesion to its managerial hierarchy. Following Weber, Mann defines this new bureaucracy as a system, involving "insulation from the wider society's struggles over values", in which officials are

"separated from ownership of office by an employed, salaried status, ...appointed, promoted and dismissed according to impersonal criteria of competence, [and]...organised within departments, each of which is centralised and embodies a functional division of labour... [and] integrated into a single overall administration". ${ }^{81}$

\footnotetext{
78 Cited in Ibid. pp 429-430. Mann estimates that, "by 1910 perhaps 20 per cent of adult males in most countries had been so disciplined", a figure that was surely to rise much higher as a result of the World Wars (ibid.).

79 Ibid. p. 393.

${ }^{80}$ Ibid. Mann notes that these must be taken with a considerable conservative bias as the numbers of casual workers, particularly women, are very difficult to quantify accurately and have therefore either been excluded from the data or likely to be severely under-counted (p. 391).

${ }^{81}$ Ibid. p. 444. My parentheses.
} 
Supported by the ideologues of middle-class liberalism, civil administration was thoroughly institutionalised by 1914 and providing "the most important way state elites penetrated civil society" ${ }^{82}$ So, although patronage remained, ensuring that the top posts went to class and party loyalists, the state, for Mann, "was no longer an instrument of patriarchal household authority... Its 'civil servants' were avowedly neutral, entrusted with the best interests of national civil society". ${ }^{83}$

Thus the state was rationalised and, under pressure from decentralised networks of industrial-capitalist nationalism (the fourth of Mann's phase of nationalist development), forced into adopting a greater civilian function. Legislation became more systematic and, from the 1860 s, was presented to parliament by ministers not private members, commissions of enquiry were championed to investigate the conditions of civil society and government took a more direct interest in issues of public morality. The state's infra-structural powers grew enormously as financial concerns regarding a wider state role diminished in the face of even greater economic growth. For the rapidly expanding middle classes a more technocratic and interventionist state, necessitating greater centralisation, was, Mann contends, a means of dividing and reducing the influence of the provincially-based old regime. It was also in keeping with the concept of national efficiency determined by a healthy family, a basic level of education for all and an economy unburdened by class conflict. When reforms initiated by the philanthropic bourgeoisie successfully entered the statute book, they simultaneously tended to extend the state's capacity to distribute power and, through its collective organisation, such as Edwin Chadwick's sanitation schemes, enhance the power of civil society at all levels.

82 Ibid. p. 473.

83 Ibid. p. 470. 
As the 'freedom' from state intervention versus the 'modernity' of a bureaucratised nation-state dichotomy condensed into party politics, enfranchisement was extended and elites were institutionalised, paradoxically in the case of federalists, into centralised political organisations away from the locally-rooted issues of the provinces. By 1900 Mann writes that these "were appealing to a mass electorate sometimes over the heads of local notables, reducing their autonomy and moderating their preference for federalism". ${ }^{84}$ The decline of provincialism was also carried through a great increase in letterwriting and easier mobility through more extensive transportation infra-structure, both of which tended to diffuse the fashions and lifestyles of the centre. Wage levels began to even out across the different regions, as did property prices and demographic indices, leading to much greater national integration, symbolised by the monarch's photograph on the wall or the local newspaper's interest in the processes of state. So, Mann concludes, as "the national organisation of civil society, and of capitalism and its classes increased", the international discourse of labour and religious ideologies was organisationally outflanked as "the infra-structural state nourished the nation-state" ${ }^{85}$

Regional differences diminished further as state-financed education developed and spread the linguistic style of the centre intensifying and reinforcing what Mann calls "the state's national crystallisation". ${ }^{86}$ As school enrolment increased dramatically, ranging from 74 per cent in Austria to 88 per cent in France in the industrial nations by the turn of the century, the secular, centralising state developed its educational infra-structure by assuming control of the majority of private sector schools and enlarging their own institutions bringing local, regional or central governmental bodies into conflict with regional and minority religious interests. ${ }^{87}$ While partly a function of industrial-capitalist

\footnotetext{
84 Ibid. p. 484.

${ }^{85}$ Ibid. p. 489, his italics.

86 Ibid. p. 575.

${ }^{87}$ Ibid. p. 488.
} 
requirements, this exponential expansion of educational provision "also reflected dominant class desires for social control and subordinate class desires for 'ideological citizenship"' ${ }^{88}$ Indeed, Mann claims that 'the 'credentialism' often identified as central to middleclass life was itself shaped by these". ${ }^{89}$ Elementary schools, the maximum most could afford, provided the student with just enough to gain employment as a clerk and emphasised the qualities of reliability and discipline as much as academic achievement. For those with means there was the option of the 'modern', which filled the ranks of lower white-collar posts, or the 'classical' secondary school which controlled university admissions. Although in the northern United States such segregation was not so apparent (in southern states it was determined by race), in Europe the expansion of education along what Mann describes as segmented lines enabled "middle-class families to share in the cultural life of the nation and to distinguish themselves from workers and peasants below". ${ }^{90}$

"State education was officially nationalistic. Schools were supposed to encourage a rather military sense of nationhood". 91 This conceived sense of national belonging, Mann argues, became, amongst certain social groups, equated with what he terms 'aggressive modernist nationalism.. ${ }^{22}$ While perceptions of national identity had long since been accompanied by racism and intolerance, it had generally been institutionalised to legitimise European violence against the nonwhites of the colonies, or potential colonies. With the expansion of state infra-structure, nationalism became more territorially defined amongst social groups closely associated with the state, but not at its core. State-employed careerists, university graduates and military reservists, rather than the petite bourgeoisie, were thus inclined to became "super-loyalists or nation-statists with an exaggerated loyalty

\footnotetext{
88 Ibid. p. 572.

${ }^{89}$ Ibid.

${ }^{90}$ Ibid. p. 573.

91 Ibid. p. 586.

${ }^{22}$ Mann, M. (1995) p. 55.
} 
to what they conceived to be the ideals of their nation-state". ${ }^{93}$ This tendency, which Mann characterises as 'state-reinforcing', was a feature of industrialised countries where the nation and state were increasingly perceived as coterminous. Similarly the initially 'statecreating' pan-nationalism of Prussia and Piedmont became 'statereinforcing' as state and nation coalesced. In Austria, however, nationalism was eventually to take a different route as the nation, supported by the diplomats of Paris in 1919, was conceived as smaller than the overall state and was therefore, in Mann's terms, 'statesubsuming'. While popularity and rhetoric varied greatly from country to country, 'super-loyalism's' exponents did not generally represent the bulk of early-nineteenth century society and the First World War (a conflict not remembered for its toll of ideologically-driven atrocities) quickly accounted for the early volunteers of which they were a part.

\section{Critical Appraisal}

Mann's work has certainly not passed without considerable critical debate. As Gary Runciman has noted, in placing his work in the midground between narratives based on preconceived notions of historical significance on the one hand and studies seeking to apply general theories to the overall human condition on the other "he risks being simultaneously attacked by one set of readers for writing potted history at a safe distance from the sources, and by another for theorising at an insufficiently high and abstract level". ${ }^{94}$ This has indeed proved to be the case as both historians and empiricists have criticised Mann's approach to the material set out above and questioned the overall methodological foundation of his investigation. Furthermore, damaging criticisms have been raised from within the discipline of macro-sociology over a number of issues relating to Mann's historical discourse as well as his theoretical basis.

${ }^{93}$ Ibid.

${ }^{94}$ Runciman, W. (1987) p. 7. 
Prominent amongst these, has been Mann's lack of comparative breadth. However, this is not, as some have argued, an oversight on the author's part. In following Talcott Parsons' definition of society as possessing only a limited degree of interactive patterning to differentiate it from broader social totalities ${ }^{95}$ and concluding that they are therefore "not self-contained units to be compared across time and space", Mann consciously rejects the use of the comparative method as his primary analytical tool. ${ }^{96} \mathrm{He}$ states that, having been "confronted by the empirical reality" of finding an inadequate supply of autonomous, analogical cases upon which to base a comparative enquiry, he turned "pragmatically to the second method, of careful historical narrative... to see if it has the feel of a pattern, a process or a series of accidents and contingencies". ${ }^{97}$ Such an approach, Mann suggests, not only has the benefit of alleviating the problem of the small $N$, or too few cases with which to compare an often great number of variables, ${ }^{98}$ but also allows him to pursue contextualised lines of inquiry determined by the socio-historical uniqueness of the subject matter. His narrative is thus quite different from those grounded on the kind of inductive system of logic devised by John Stuart Mill and espoused by writers such as Theda Skocpol. ${ }^{99}$ He does not, then, attempt the large-scale synchronic comparisons which characterise the work of Weber, preferring instead to focus his study on European power development stating that "the most appropriate history" with which to analyse power "is that of the most powerful human society, modern Western civilisation". ${ }^{100}$

Nevertheless, in order to establish that the course of history in one

\footnotetext{
${ }_{95}$ Parons, T. (1960) p. 9.

${ }^{96} \mathrm{Mann}, \mathrm{M} .(1986)$ p. 30.

97 Ibid. p. 503.

${ }^{98}$ Indeed, Mill considered the problem of finding sufficient comparable cases within the social sciences so severe that he described any attempt to do so as a "gross misconception of the mode of investigation proper" (Mill, J. S., 1843, Book VI, Ch. 7).

${ }^{99}$ See her study of France, China and Russia (1979) p. 36.

${ }^{100}$ Mann, M. (1986) p. 31.
} 
society is different from that of another, some comparison is unavoidable, particularly if the nature of social power and the sources of social change are, as Mann suggests, to be regarded as inherently 'interstitial' and territorially unbounded. This is not only essential to demonstrate Western specificity, but also inevitably exists as an intrinsic relational element between one narrative sequence and another. For instance, Mann's identification of the ecological peculiarities fundamental to the origins of political administration in Mesopotamia cannot be established without excursions into other regional landscapes and processes. His methodological emphasis on historicity, however, means that his narrative has difficulty absorbing the more deviant variables of the topologically dissimilar Nile system, for instance, or, for that matter, the utterly different geography of Mayan development. The implications of these contradictions are hurriedly passed by for, as Perry Anderson notes, "only a comparative analysis - more firmly inductive in spirit - could offer a hope of coherent explanation". ${ }^{101}$

This problem becomes compounded as Mann approaches what Weber described as the 'old question' - that of why such exponential development occurred only in the European north-west. Here, he is forced into a brief perusal of other world religions in order to support his characterisation of Christianity as uniquely influential. After a superficial theological survey he concludes that Confucianism was too ethnically-orientated, Hinduism too hierarchical and Islam overly tribally determined. In contrast, Mann argues, Christianity's greater spiritual sophistication and social inclusiveness proved, once it had spread through the Roman world, "so far superior to the others that all had to adapt to its encroachments" becoming the 'track-layer' for the European 'miracle'. ${ }^{102}$ So rather than the logistical difficulties of a

${ }^{101}$ Anderson, P. (1986) p. 1405. In Volume Two of the Sources of Social Power, Mann does, in fact, pursue a more comparative line. While he does not revise his earlier assertions regarding the methodological difficulties of such an approach, Mann explicitly seeks to compare different Western regime strategies.

${ }^{102}$ Mann, M. (1986) p. 341. 
battleground so far from home, the Muslim armies, for instance, were defeated at Tours and Poitiers in 732 because of the superior ideology underpinning Christian military morale. ${ }^{103}$ Here, Mann's comparative discourse is particularly thin demonstrating, in my view, his reluctance to digress from his central thesis of north-western European progression and severely weakening his empirical control over many of his hypotheses.

To take Mann's treatment of Islam as an example, he fails to demonstrate its lack of sophistication and social inclusiveness in relation to Christianity. Mann argues, in contradiction to his earlier assertions regarding tribalism, that loyalty to the ummab superseded local and intensive networks and embedded the adherent into a quasiegalitarian federation similar to that of the Christian ecumene. This may well be so, but the economic differences between the Muslims' theocractically governed, and often heavily circumscribed, trading system and an ecumene dominated by the merchant classes without such comprehensive ideological regulation go unexplored. ${ }^{104}$ Instead, shared rituals, the spread of Arabic as the language of education and administration and the comprehensiveness of Shariah jurisprudence are emphasised as providing, despite the lack of a hierarchical clergy, a social basis broadly akin to European Christendom. In common, he continues, was "a diffuse and extensive sense of cultural community, a precise infra-structure centred on a monopoly of literacy, a fairly high level of intensive penetration of everyday life, and a relatively weak social cosmology". ${ }^{105}$ These comparisons are too broad to be very instructive and do not account for the way in which the Arab, and then the Ottoman, imperial state organised ideological power and maintained their economic position. The failure to discuss the social position of non-Muslim dhimmis/millets or contrast their mercantile

\footnotetext{
103 Ibid. p. 346.

104 As Perry Anderson comments, "there was a good deal more enforcement of it [normative pacification] in Abbasid or T'ang lands than in the world of Charles the Bald" (1986, p. 1406). My parenthesis.

${ }^{105}$ Mann, M. (1986) pp 347-348.
} 
and jurisprudential role with that of the Muslim majority is, for example, a notable omission. ${ }^{106}$

This is also true of his continual reference to Christendom to mean only its Roman, as opposed to Orthodox form. Aside from providing a useful basis for analysing interaction with its Muslim neighbours to the south and east, Mann's reluctance to discuss the peculiarities of the Eastern Church, which certainly did not lack a social role in Byzantium, leaves the question of why no similar development occurred in Anatolia or Rumelia unanswered. As Perry Anderson comments, "by recasting a Weberian claim for the catalytic role of religion in generic Durkheimian form, Mann deprives himself of any reasonable basis for claiming special privileges for Christianity". ${ }^{107}$ In other words, the specificity of the Protestant ethic's relationship with the spirit of capitalism as a causative element in north-western European development is replaced by the more general notion of religion as a broadly cohesive social force. Nevertheless, Mann has elsewhere argued that, rather than stemming from the existence of a value consensus, social compliance in modern liberal democracies might be more convincingly explained by the "pragmatic acceptance of specific roles than by any positive normative commitment to society". ${ }^{108}$ This is a surprising contradiction, particularly in the light of his introductory assertion that societies tend not to be bounded by any one (in this case ideological) power network. It may, perhaps, derive from the logical constraints imposed by his subsequent characterisation of social power as primarily concerned with exerting a controlling or co-operative influence over others rather than its capacity to resolve human tensions with the natural world. As Anderson puts it, "theology is, so to speak, over-socialised". ${ }^{109}$

\footnotetext{
${ }^{106}$ See Karpat, K. (1973) for a fuller discussion of the position of non-Muslims under the Ottomans. ${ }^{107}$ Anderson, P. (1986) p. 1406.

108 Mann, M. (1970) p. 435.

${ }^{109}$ Anderson, P. (1990) p. 61.
} 
Furthermore, Mann's characterisation of Christianity as the first ideological organisation to gain independence from the state and posses its own causal force has also attracted considerable critical attention. Chris Wickham, for example, argues that, rather than providing a new method of linkage between the state, ruling classes and the masses, Christianity "merely put a new veneer over several interlocking (and conflicting) sets of traditional classical values." Methods of ruling class dominance, including restrictions on literacy and religious education, were not, he asserts, significantly affected by the victory of Christianity which simply served to legitimise existing economically-determined relations. While Mann acknowledges this, writing that "the church enhanced the class morale of lords, clothing their exploitation with sacred qualities", 111 he continues to stress Christianity's role in normalising property rights and extending trade over greater areas than was possible under the disparate and predatory European court system that had replaced Roman extensiveness.

Wickham disagrees, however, arguing that a more likely reason for the increase in long-distance trade during the twelfth century was that travelling merchants were protected by the pacifying influence of the Merovingian and Carolingian Franks' political and military network. It was, he continues, the material value of this ideological allegiance, in a cultural rather than religious sense, which supported and legitimised the nascent feudal economy and not the normative extensiveness of Christianity. Non-Christian traders within Europe, such as Vikings or Arab Spain, Wickham contends, were not significantly disadvantaged by their religious affiliation providing they did not question the supremacy of the Frankish courts. Thus, it may well be stretching the idea of social cohesion too far to claim, as Mann suggests, that it was the ideological power of Christianity's social networks which prestructured the basis for capitalist exchange in early medieval Europe.

110 Wickham, C. (1988) p. 70 . His parenthesis.

111 Mann, M. (1986) p. 384. 
Undeterred, however, he concludes that, even by the mid-twelfth century, north-western Europe, "bound loosely together by the normative pacification of Christendom... was already the most agriculturally inventive civilisation since the Iron Age had begun". ${ }^{112}$ This is rather too broad. Chinese agriculture of the day was every bit as advanced producing generally higher yields, involving equally complex social organisation and supported by a sophisticated mercantile credit system. ${ }^{113}$ In defending his refusal to confront the question of why China did not emerge from the Sung dynasty in the way that north-western Europe did from early medieval feudalism, Mann points to four differences: "Europe's economy was not rice dominated, and it was extremely varied; its states were weak; it was a multi-state civilisation; and its religion and culture expressed the spirit of rational restlessness". ${ }^{114}$ In the absence of concomitant variations, he continues, the comparative method cannot be applied.

Such an uncritical justification of narrativism is, for many commentators, particularly unsatisfying. It is not, however, based upon epistemological concerns, for Mann's work, as discussed, is unavoidably comparative in other areas. Rather, Mann claims, it is simply grounded on the practical difficulties of drawing out such comparisons. It may be, though, that the Eurocentrism of Mann's pursuit of the 'leading edge' of civilisation has its foundations on textual rather than theoretical concerns, or, as Perry Anderson puts it, "this restriction may have been less the intellectual impossibility of creating a wider framework than the compositional gain of a narrower one". ${ }^{115}$ In this sense, Mann's aim in constructing 'the rise of the West' is to set out a virtually unilinear 'macropattern' of history linking Sumer with the First World War in a diachronic discourse deliberately simplified to provide maximum contextual depth and explanatory value. Such a voyage is bound to have a teleological feel

112 Ibid. p. 500.

113 Wickham, C. (1988) p. 74.

${ }^{114}$ Mann, M. (1986) p. 502.

${ }^{115}$ Anderson, P. (1986) p. 1406. 
to it, particularly the condensed version set out in the earlier sections of this chapter, but Mann is consistent in stressing that "there has been nothing 'necessary' about it - it just happened that way". ${ }^{116}$

Having constructed the ideological impetus for Europe's 'leading edge', Mann's abiding emphasis on power as an intra-social function rather than a method of interacting with nature leads him to focus on military and political processes in preference to more orthodox economic interpretations. ${ }^{117}$ As a result, his account of feudal relations of production, particularly the landlord-peasant connection and the extent of the state's economic expropriations are, as Wickham notes, insufficiently theorised leaving the actual forces of extraction and circulation unexplored. ${ }^{118}$ Moreover, in refusing to attribute ultimate causality to any of his four sources of power, John Haldon argues that Mann is guilty of specifying an 'aprioristic' framework of analysis. ${ }^{119}$ While this, which may be taken to mean arbitrarily establishing the level of discourse, is no less true of Haldon's own historical materialist approach, it may well be the case that "if Mann had looked more at peasants, besides his well-described and well-documented interest in structures of domination over peasants, the material base of that domination would have become clearer". ${ }^{120}$ Indeed, Mann frankly admits that his chapter titled International Capitalism and Organic NationStates 1477-1760 "lacks what perhaps it should ideally possess, a sustained explanation of the various stages of economic growth toward the Industrial Revolution". ${ }^{121}$ He justifies his uneven treatment of history by arguing that power also develops unevenly in "jumps". ${ }^{122}$ In omitting to illustrate fully the culturally-specific trajectory of economic power distribution, however, not only does Mann miss the

116 Mann, M. (1986) p. 31.

${ }^{117}$ For a discussion of the degree to which Mann succeeds in taking a middle line between characterisations of the state as the instrument of class relations on one hand and rational actors on the other, see Terry Mulhall's review of Volume II of The Sources of Social Power in the British Journal of Sociology.

118 Wickham, C. (1988) p. 77.

${ }^{119}$ Haldon, J. (1991) p. 42.

120 Wickham, C. (1988) p. 77. His emphases.

121 Mann, M. (1986) p. 450. 
opportunity to establish his model of change more firmly, he also leaves the controversy surrounding the universality of feudalism unobserved. Clearly not wishing to digress from the north-west European 'leading edge', no mention is made, for example, of the concept of the tributary mode of production despite its obvious relevance to the state autonomy debate.

Even within the parameters of his exposition, however, there exists a paradox in Mann's formulation of the state's position vis-à-vis civil society's pre-eminent economic class. As military power is often to be found in civil organisations, it is the state's political centrality rather than its monopoly of coercive force which underpins its autonomy. Yet since, as Anderson observes, "political regulation is scarcely conceivable without the resources of armed coercion, fiscal revenue and ideal legitimisation", this source of power "enjoys least autonomy of all". ${ }^{123}$ Furthermore, as the state's extensive and comprehensive infra-structural capacity to penetrate its territory develops, society as a 'bounded totality', which Mann's theory initially denies, appears to emerge. As a result, critics have argued that "Mann's explanation of variations in state autonomy... is too incomplete and vague to yield precise empirical implications". ${ }^{124}$ His treatment of war initiation, for example, is sometimes grounded on assumptions of material interests and at other times on normative constraints. In the view of Kiser and Hechter, this inconsistency prevents him from developing a general association between monarchic autonomy, the state's possession of independent resources and conflict instigation which other, more empirically rigorous studies, have uncovered..$^{125}$

Indeed, this perceived lack of empirical potency has led some commentators, such as Gerhard Lenski, to dismiss the macro-

\footnotetext{
122 Ibid. p. 31.

${ }^{123}$ Anderson, P. (1990) p. 61.

${ }^{124}$ Kiser, E. \& Hechter, M. (1991) p. 19.

125 Ibid. p. 22.
} 
sociological approach altogether. ${ }^{126}$ It lacks, he writes, "substantive conceptual links to established theories in other scientific disciplines" and is "not falsifiable in the same unambiguous manner as theories in the natural sciences". ${ }^{127}$ Despite scientists from other fields having no immediately obvious qualifications to legislate in the social sciences, Lenski continues by asserting that these "critical flaws" have led to a plague of competing theories generally unconnected to empirically generated data the substantiation of which is "more an art form than a science". ${ }^{128}$ Undeterred by several hundred years of unsuccessful endeavours in pursuit of general social laws as convincing as those in the natural sciences, Lenski and fellow 'neopositivists', declaim, by way of a remedy, the value of adopting mathematical and probabilistic formulations of theories and hypotheses in order to minimise ambiguity and replace "vague and indefinite terms" with precise values. ${ }^{129}$ Quite how simplified formalism more accurately represents the complexities of reality is unclear, as is the superior explanatory value of elaborate and convoluted causal matrices.

For Wassily Leontief, it is deliberately obscurantist tending to "conceal the ephemeral substantive content of the argument behind the formidable front of algebraic signs". ${ }^{130}$ Moreover, as Bernd Baldus points out, this 'dataphilia' is quite contrary to the predominantly theory-led neopositivism of Popper, Hempel and others. ${ }^{131}$ Stemming from the failure of its core epistemological construction (that of linear determinism) and the professional value of working in a 'hard' science freed from the constraints of theoretical evaluation, he argues that,

126 Mann summarises macro-sociologists' approach in three ways. "An bistoricalcausal analysis of origins considers the conditions which give rise to modern institutions relevant to understanding their present nature and likely persistence... A quest for variation seeks to understand modern institutions like capitalism or the nation-state or particularly by comparing them with social groups with other types of economic, political or gender institutions... A more abstract-comparative macrosociology, less tied to understanding the present, analyses the past to test more general propositions about human communities" (1994, p 39). His emphases.

127 Lenski, G. (1988) p. 163.

128 Ibid. p. 166.

129 Lenski, G. (1991) p. 188.

${ }^{130}$ Leontief, W. (1971) p. 2.

131 Baldus, B. (1991) p. 196. 
modern positivism has, in Abraham Kaplan's words, "contributed to a 'myth of methodology: that it does not matter what we do if only we do it right". ${ }^{132}$ Indeed, any resistance to this monist programme is, in Hubert Blalock's view, to be considered an 'anti-science attack' orchestrated by "the poets and artists among us". ${ }^{133}$ In this way 'facts' are aggregated from the data-set of history, stripped of their determinant contexts and processed by a mechanistic statistical analysis regardless of their intrinsic aptitude to such reductionism and in ignorance of their diachronic variance and cultural specificity. ${ }^{134}$

If theory and data are to remain separate in order to demonstrate that the former has general applicability, as positivists demand, where then, if not from a blend of the culturally-determined imagination of the researcher and the data itself, is theoretical innovation to come from? Nicky Hart argues that empirical material's "very form is dictated by theoretical concepts operationalised as variables using linguistic categories which may themselves impose specific cultural understandings". ${ }^{135}$ Mann too, follows this Kantian formulation. Data, he argues, enmesh with theories, each exerting an evaluative influence over the other, and can only be significantly employed through internally generated meaning systems. ${ }^{136}$ In the same way as other scientists, macro-sociologists formulate hypotheses on the bases of theoretical inklings which are then illuminated by the systematic pursuit of data. Mann, for instance, supports his account of largescale European change with an extensive exploration of English state finances from the twelfth century onwards based on biannual

\footnotetext{
132 Kaplan, A. (1968) p. 394.

${ }^{133}$ Blalock, H. (1984) p. 25. As Joseph Bryant insightfully notes, though, "the expediency of such rhetoric is of course readily apparent, for by consigning all opposition to an 'anti-science' fringe, the proponent evades confrontation with those serious intellectual arguments which might expose his own untenable extremism" (Bryant, J., 1992, p. 38). For a broader discussion see the essay by Fritz Machlup, 'Are the social sciences really inferior?' (1963).

134 See, for instance, Guy Swanson's ludicrous treatment of Yahweh and the Lengua's beetle-god. Despite being utterly different in time, space and cultural significance, these are formulated as statistical equivalents in explaining the origins of monotheism (1960, Ch. III).

${ }^{135}$ Hart, N. (1994) p. 22.

${ }^{136}$ Mann, M. (1994) p. 42.
} 
Exchequer Rolls. In doing so, however, he had to rely on the translations and tabulations of specialist historians. While "unconcerned with their interpretations of the politics of the day, [and] unconcerned with their theories of kingship, Church-State relations or the rise of Parliament", he was also obliged "to accept some combination of their various methods of data categorisations". ${ }^{137}$

This reliance on secondary sources has led some sociologists to accuse Mann and others of not basing their methods on prima-facie evidence. John Goldthorpe, for instance, argues that the connection between macro-sociologists' claims about the past and what he terms the 'relics' (historical material such as artefacts, documents and so on) has become "impossibly loose". ${ }^{138}$ What happens, he asks, when secondary accounts disagree? Without knowledge of the primary source, the macro-sociologist, he suggests, is unable to choose the most convincing interpretation so merely opts for the one that best suits his overall thesis. ${ }^{139}$ History thereby becomes, in Froude's words, "a child's box of letters with which we can spell any word we please". ${ }^{140}$ Part of this problem, for Goldthorpe, is that the 'relics' upon which historians rely are limited and incomplete so without engaging in primary research which might challenge their validity macro-sociologists base their assumptions on a positivist acceptance of the evidence. He concludes that, rather than making up an integral part of the investigator's methodology, historical inferences should instead be used to provide the setting for sociological fieldwork over which there exists far greater empirical controls. ${ }^{141}$

${ }^{137}$ Ibid. p. 44. My parenthesis.

${ }^{138}$ Goldthorpe, J. (1991) p. 223.

${ }^{139}$ See Goldthorpe, J. (1994) p. 69.

${ }^{140}$ Froude, J. (1884) p. 21.

${ }^{141}$ Here Goldthorpe points to "the very real advantages that are gained where the nature and extent of available evidence is not restricted by the mere accidents of physical survival; where, moreover, the collection of evidence can be 'designed' so as to meet the specific requirements of the inquiry in hand; and where questions of 
While it is undoubtedly true that investigating the present has great advantages in terms of research design, it does not mean that sociology, in the form recommended by Goldthorpe, is methodologically superior. For, as Bryant inquires, "what sociologist would not be keen to view the present from the vantage point of the future, with retrospective knowledge of the trends that emerged triumphant and those that fell by the wayside"? ${ }^{142}$ Indeed, the results would surely differ from both the subjective expectations of the participants in the present and from contemporary documentation limited as it is by the constraints of private property and official confidentiality. This is a particular problem for research where power prominence is a factor. The difficulties in gaining access to social elites, as primary evidential material, and to studies not based on samples containing a disproportionately high number of 'ordinary' respondents often prevents the sociologist from generating suitable data. Such a "democratic bias", as Mann calls it, ${ }^{143}$ does not typically constrain the historian whose empirical basis represents the 'relics' of those individuals and institutions with sufficient resources to dominate the media of cultural expression. Furthermore, the residue of the past, as unsolicited and "authentic elements of past social worlds", 144 brings the investigator just as close to the reality of the subject as the questionnaire or interviewer which intrude, as foreign elements, into the social setting they attempt to describe, conditioning attitudes and forcing responses into preordained categories determined by the subjective proclivities of the sociologist. In this sense then, extrapolating from what $\mathrm{C}$. Wright Mills calls the "curious behaviourism"145 of generated sociological data is every bit as inferential as employing the colligation of historical 'relics'.

That is not to say, however, that the 'relics' of the past can, out of an

the quality of evidence can always be addressed, as they arise, by generating yet further evidence through which to check and test the original" (1991, pp 214-215). 142 Bryant, J. (1994) p. 7.

${ }^{143}$ Mann, M. (1994) p. 38.

144 Bryant, J. (1994) p. 7. 
intrinsically held significance, inform the inquirer. Rather than speaking for themselves, each can only be rendered meaningful when placed in a framework mediated by the current contours of conventional wisdom and scholarly debate. Macro-sociologists, like other sociologists and historians, order their findings to present a reasoned account of the phenomena they seek to describe. In the inevitable event of disagreement, the reader brings to bear other findings and interpretations, makes judgements concerning factuality and, as Mann concludes, rejects part of all the accounts on offer. Since, ultimately, both the generated evidence of empirical research and the 'relics' of the historian are, as Nicos Mouzelis points out, "second order interpretations referring to the first order ones that individuals generate when they act and interact", ${ }^{146}$ all evaluations of plausibility are informed, in part at least, by how well the evidence presented is accounted for by the internal cohesion of the analysis. The fact that human agency is "fundamentally time-referential, with the consequence that social actions are to be understood not as episodic events or discrete occurrences, but as complex durational processes", ${ }^{147}$ means that the macro-sociologist must therefore fuse idiographic and nomothetic approaches in order to maintain a contextual logic in keeping with the observable complexities of the subject.

\section{Conclusion}

So, while based on sound methodological principals, Mann's work is weakened by its excessively linear approach. In failing to analyse both the differing imperial heritage of West and East and their contrasting institutionalisation of phenomena such as secularism, state centralisation and capitalism means that comparative aspects to his treatment of European social change are lost. Furthermore, he misses

${ }^{145}$ Wright Mills, C. (1959) p. 70.

146 Mouzelis, N. (1994) p. 35.

147 Bryant, J. (1994) p. 18. 
the opportunity to vary his historiographical argument with examples which might have reinforced his thesis on the specificity of northwest European development. This is a pity as a greater degree of contact with non-Western cases would have brought greater explanatory value to Mann's more general account of the emergence of the early nation-states. It would also have further allowed him to test his theoretical rubric and thus strengthen his claim upon general applicability.

What is required in order to resolve some of the problems highlighted above is, therefore, an extension of Mann's work which adopts a more firmly comparative approach. Such a study could cast further light on Mann's account and reduce the Euro-centrism of macrohistorical sociology generally by seeking to comprehend more fully the variation between European and non-European social dynamics. An analysis of this kind could refine our understanding of large-scale change in Europe in three ways. Firstly, in focussing on the commonalties between points of development around the world, light can be cast on Europe's shared socio-historical heritage. To this effect, Mann's universal theory of power organisation and contention could be deployed to elucidate social 'crystallisations' (such as nationalism, secularism, class, militarism and economic development) which are of general relevance. Secondly, by looking at the significant areas of difference between two evolutionary patterns, a greater understanding of European specificity could be obtained. Not least amongst these might be the rapidity of social change and the persistence of social cleavages built around ethnicity, religiosity and social status. Thirdly, in bringing a new case to Mann's account of historical continuity, a refined comprehension of social power can be sought which better explains a non-European pattern of organisational development.

To this end, the following four chapters will apply Mann's model to the development of the Ottoman/Turkish state. Such an application 
of a leading approach within macro-historical sociology will offer support for the discipline as a whole. For, as Arend Lijphart has stressed, an alternative case can contribute "to the establishment of general propositions and thus to theory-building". ${ }^{148}$ This may simply be the utility of accumulated data presented as a non-theoretical descriptive study which can then be employed as a secondary source $^{149}$ or, as in the case of this thesis, it may have further interpretative value. In applying Mann's approach, it will be possible to illuminate some of his more generalised propositions, suggest some revisions and consider the alternative case study in relation to his own supporting evidence. This more firmly comparative approach will address the deficiencies of Mann's analysis discussed above and highlight some of the more significant areas of theoretical importance for the general study of state development and social change.

\footnotetext{
${ }^{148}$ Lijphart, A. (1971) p. 691.

${ }^{149}$ For a discussion of the value and limitations of this, see Curtis, M. (1968) p. 7.
} 


\section{Chapter Three: The Politics of Empire}

This chapter seeks to explore the Ottoman state's methods of rule by applying Michael Mann's theoretical model of social power to its changing relationship with civil society. It will look at the mechanics of Ottoman political and ideological organisation and the ways these sustained the position of the state vis-à-vis the military and civil society. Mann's identification of the 'channels' of ideological communication and his construction of the methods of 'compulsory co-operation' will both be examined as a possibly useful means of understanding the dynamics of imperial territorial conquest and social absorption. While Mann developed these in relation to the political administration of Mesopotamian and Classical rulers, here they will be applied to the Ottoman system of governance as a way of ascertaining the importance of these methods in the establishment and maintenance of centralised political power and the institutionalisation of ideological legitimacy. ${ }^{1}$ Elements of continuity and change will be considered in order to illuminate social relations within the empire and to analyse Mann's account of imperial rule. The organisation of political centrality will be considered, particularly in relation to infrastructural networks of ideological power, as the state's supervisory pre-eminence crystallised before eventually beginning to falter as challenges to its ideological-political unity emerged.

\section{The Ideological/Military Complex}

A central feature of Ottoman social organisation from the early processes of imperial coalescence onwards was the unifying, or what Michael Mann would call the "pacifying normative", effects of Islam. ${ }^{2}$ Indeed, as Mann has noted, a fundamental problem for systems of

\footnotetext{
1 For the early centuries of Ottoman rule, this study will largely focus on the Rumelia and Anatolia from which the state social systems were gradually expanded (see Heper, M., 1980, pp 99-100, n. 3).

2 Mann, M. (1986) Ch. 10.
} 
imperial governance was that, in order to secure political control, military power had to be diluted. This was no less true of early conquests by the Ottoman empire. Unlike the more mercantile Mesopotamian empires, however, the partners of the generals (gazis) who administered the Ottoman frontier on behalf of the core were dervishes and religious scholars. ${ }^{3}$ The state's capacity to extend its infra-structural reach into what was rapidly becoming a large and socially diverse territory was reliant, from the outset, on this partnership's ability to 'imperialise' Islam. It was not simply the material value of conquest or the superior might of cavalry, although these were of course major factors, which legitimised the position of the peripheral agent, but rather the horizontal character of an official state culture linking centre to frontier. As the nascent state's material requirements developed, however, the core took an increasing share of the gazis spoils, provoking varying degrees of resistance and an endemic conflict between central and peripheral power. ${ }^{4}$ Since "successful booty or conquest warfare tends to heighten the State versus society stratification", ${ }^{5}$ imperial expansion also recast the horizontality of the centrist ruling group into a more hierarchical structure in turn necessitating greater political power and ideological legitimisation. To this end, Selim I's (1512-1520) assumption of the Caliphate in 1517 further enhanced the Ottomans' ideological extensiveness giving it greater infra-structural reach than that offered by the centrality of a merely political organisation structure and a more comprehensive level of collective power than the blunt application of military coercion. ${ }^{6}$ As Mann notes, a religiously centred culture provided "a sense of normative identity and an ability to cooperate... that was more extensive and diffuse than state, army, or

${ }^{3}$ See Togan, I. (1991) pp 195-196.

4 Mardin, S. (1971) explains this process in greater detail, pp 618-622.

${ }^{5}$ Mann, M. (1977) p. 289. As Mann points out, this is for two reasons: "leadership in emergency situations (of which wars are the clearest examples) needs the speed of authoritarian decision-making, and thus, secondly, booty will normally be distributed by the military-state leadership" (ibid.). His parenthesis.

6 It is unclear if Selim claimed to be Caliph over the entire ummah, see Inalcik, $H$. (1968) for an alternative view. 
mode of production provided".7 To this end, state ideological ascendancy was institutionalised by imposing Sunni orthodoxy and by establishing a body of ulema "clearly integrated with the apparatus of the state". 8

Through the close alliance between political power and the complex and comprehensive world view of Islam, as represented by the presence of the ulema, the Ottoman state was able to reinforce its links with the periphery to the detriment of the diffuse networks of ideological power already existent within the periphery. The ulema's highly centralised role controlling the education system, the judiciary and the administrative service positioned the upper echelons of the clergy at the very centre of the Ottoman state. ${ }^{9}$ They ensured the state's control of a huge and disparate populace by establishing the legality of private ownership, protecting non-Muslim citizens, arbitrating between disputants and promoting urbanisation through their educational networks. In return the sultan respected the ulema, supported their judicial decisions and used their influence and edicts in virtually all matters of state. ${ }^{10}$ The position of the ulema leadership at the heart of the Ottoman administration thus ensured that the realms of political and ideological power remained very strongly linked.1" "This union of faith and state encouraged an especially strong form of statism. ...Loyalty to the state, combining government and religion as it did, became the paramount concern for the ruling group". 12

This ruling group, headed by the sultan, was the askeri which, in addition to the office of the monarch and the grand vizier, consisted

\footnotetext{
7 Mann, M. (1986) p. 21.

8 Mardin, S. (1981) p. 194.

9 See ibid.

${ }^{10}$ A useful account of this mutuality is to be found in Hourani, A. (1974)

"For a broader analysis of Muslim society's tendency to unify ideology and politics, see Eisenstadt, S. (1984) pp 11-13.

12 Frey, F. (1978) pp 47-48.
} 
of three branches. ${ }^{13}$ The first two, the kalemiyye, or scribal service, and the seyfiyye, or military, were staffed by prisoners of war and 'slaves' augmented by the devsirme system in which predominantly nonMuslim children were recruited from the periphery. ${ }^{14}$ In separating a great number of state personnel from their social networks in civil society, the problem of power decentralisation endemic to the governance of empire was thereby considerably alleviated. Allocation of initial position within all elements of the askeri classes, from labourer to judge, was subject to merit and progress remained based on 'ability and alacrity; the social status of the conscripts' families counted for nothing". ${ }^{15}$ Moreover, as the inheritance of position or property was strictly prohibited, the de-centralising influences of patrimonialism was largely impeded thereby inhibiting the development of autonomous political organisations beyond the control of the state. Where "the emergence of such bodies could not be prevented, the state attempted to dominate them and use them to maintain or extend its own power". ${ }^{16}$

The ulema, as the third class of askeri, were instrumental in this process. Not subject to the same recruitment system, but generally working closely with local state officials, the huge hierarchy of clergy, stretching from the Sultan's council to the plethora of religious officials in every provincial community, provided the state with one of its major linkages to civil society. Since only by studying to join the ulema was it possible to obtain an appointment from the sultan's

13 The ruled were the tax-paying masses, the reaya. Eisenstadt claims such distinctions between rulers and ruled are common within imperial systems (1969, p. 321). Compare, for instance, the shik and the min in imperial China (see Lattimore, O., 1962a, p. 49).

14 Since in Islamic terms all are slaves of God, an Ottoman 'slave' was not a person entirely devoid of status, but one whose status was rigidly controlled by her/his master, in this case the state. See Parry, V. (1969) pp 55-58. For a useful discussion of how the devşirme system fitted into the Ottoman polity as a whole, see Anderson, P. (1993) pp 366-368. It should also be noted that there were considerable benefits for a family to engage in this custom and was thus frequently entered into without the generally over-emphasised element of coercion. Indeed, Arnold Toynbee notes that "no pressure was put on the boys to become Muslim and none was needed" (1974, p. 26).

15 Toynbee, A. (1974) p. 26.

${ }^{16}$ Findley, C. (1980) p. 19. 
office and move from the reaya to the askeri, the Ottoman theocratic hierarchy represented "the real hinge between centre and periphery". ${ }^{17}$ In the absence of any other intermediary agents between the askeri and the reaya, the ulema both influenced ideals of political legitimacy and integrated the Muslim masses into a Caliph-led and broadly coalescent ummab. ${ }^{18}$ This was particularly important at the very fringes of imperial influence where, as long as military expansion continued, a kind of 'frontier Islam', premised on notions of jibad and martyrdom, informed a strongly statist (as epitomised by the SultanCaliph unity of religion and politics) level of social organisation. In other words, it reinforced, what Mann calls, the immanent morale of the established order and the religious proto-nationalism of the ummab-state relationship.

Like the Christian ecumene described in the previous chapter, the ulema confirmed social relations between civil society groups by providing access to educational and cultural services, by regulating property and family law and by embedding otherwise intensively organised social groups in an extensive ideological network. As Şerif Mardin concludes "wherever the aloof state failed they [the ulema] moved in". ${ }^{19}$ In contrast to Mann's analysis of Rome, however, there was not the distinction between what belongs to the monarch and what belongs to God. ${ }^{20}$ This made the Ottoman clergy far less vulnerable to state challenges. Moreover, having inherited an immense and detailed tradition of texts and precedents, the ulema did not have the same leeway of interpretative analysis as the early Christian church and thus could not be politicised as easily. In a state largely orientated by its claim to Islamic legitimacy, there could be only be limited legislation and no divergence between jurisprudence and

\footnotetext{
${ }^{17}$ Mardin, Ş. (1973) p. 174.

${ }^{18}$ For an account of the absence of a Turkish national identity in the pre-nineteenth century Ottoman empire, see Kushner, D. (1977).

${ }^{19}$ Mardin, S. (1971) p. 203. My parenthesis.

20 For a brief comparison of these two developmental patterns, see Heper, M. (1991) pp 42-46.
} 
administration. ${ }^{21}$ This synthesis of ideology and politics offered the Ottoman centre a means of intensifying its ties with the imperial periphery. Leadership on the grounds of Islam, once it had been fused with the politics of centralisation, gave the state a way of reducing the inevitable decentralisation of power which institutionalising its rule over conquered territory entailed.

The closeness of the relationship between the ulema elite and the Sultan's council was of central importance in preventing autonomous power organisations arising within this heterogeneous, diffuse and socially mobile clerical network. As long as this was maintained, the ulema's grip on educational access and legal sanction meant that alternatively organised ideological power networks, both within the theocracy and the askeri as a whole, could have only a very limited capacity to provide what Mann calls the "the cement of class solidarity".22 The unity of the askeri and their supervisory omnipresence also prevented horizontal ideological links between different civil groups within the reaya developing into decentralised organisations able to challenge the prevailing political regime. Ideological power's other facet, transcendentalism, which tends to "cut right across existing economic, military and political power networks", ${ }^{23}$ was also circumscribed by the verticality of the ulema's Caliph-to-peasant infra-structural reach. Thus, the social networks organised around the ulema remained ideologically immanent and the state was able to maintain its supervisory position over, what Mann describes as, the "authoritative, official, political-communication channel" between ruler and ruled ensuring that fatwas and canons

21 "God alone is the Great Legislator, since he has already given the Law (Sharia), divine, perfect, sufficient, unchangeable, written in the Koran for eternity in the last revelation necessary for humanity. Therefore, there is neither place nor need for a legislating state" (William Zartman cited in Ozbudun, E., 1984, p. 44). His parenthesis.

${ }_{22}$ Mann, M. (1986) pp 269-270.

${ }^{23}$ Ibid. p. 301. 
continued to be conveyed between clergy in a tightly regulated manner. ${ }^{24}$

The high level of state control over religious organisation meant that another of Mann's logistical channels of ideological power, that of "cultural traditions", remained more segmental and less diffused than in his characterisation of the homogenising influences of Roman cultural expansion. ${ }^{25}$ This was apparent in the Ottoman notion of the millet which, although later to denote a specifically non-Muslim community, was used to refer to one of the great number of distinguishable 'peoples' within the empire. While differences between the social organisation of the various ethnic, cultural and religious groups within the empire have been often over-emphasised, the point remains that the state made little attempt to impose a national ideology. ${ }^{26}$ As a result the millets remained relatively atomised. Again in contrast to Mann's model of Rome, few Ottoman citizens, both non-Muslim and Muslim, perceived themselves to be members of an imperial totality. The little 'Ottoman culture' which did develop was largely subsumed beneath self-perceptions of group identity based on religious difference. ${ }^{27}$

This strongly vertical notion of group organisation is related to Abdul Rahman Ibn Khaldoun's (1332-1395) concept of group feeling that acts as the source of social cohesion, al asabiyya. ${ }^{28}$ Ibn Khaldoun was widely read throughout the Ottoman elite (particularly the ulema); the concept of al asabiyya underpinned the ideological state's primary objective, to maintain the nizam, or social 'order'. This was the balance between ruled and ruler, between the reaya and the askeri and

\footnotetext{
24 Ibid. p. 311.

25 Ibid.

${ }^{26}$ See Findley, C. (1980).

27 See Karpat, K. (1973a) p. 38. The state also took a hand in maintaining and organising this diversity. Members of the different millets were, for example, discouraged from wearing clothes characteristic of another millet or class (see Mardin, Ş., 1967, pp 129-130).
} 
between the various groups within each. ${ }^{29}$ It was based on the socalled 'circle of justice' in which there can be no state without wealth, no wealth without the people's well-being, no well-being without justice, no justice without the state, no state without wealth and soon. Justice was determined by the state in the interest of nizam. This did not mean, however, that the approach to governance was, as some writers have argued, entirely static. The notion of inkalab or "changes effected legally through legislative, governmental or cultural means" came to be part of Ottoman political parlance as a means of forestalling the inevitable descent into anarchy that, according to the received Ibn Khaldounian wisdom, awaited all societies. ${ }^{30}$ From this basis the örfi sultani (or $\ddot{0} f$ ) emerged. It had echoes of the pre-Islamic concept of the law-bringing leader and allowed the sultan to issue decrees intended to safeguard the well-being of his community "regardless of his personal wishes" and subject to ratification by the leading ulema. ${ }^{31}$ Ostensibly based on necessity and reason, the Sultan's legislative flexibility gave the Ottoman executive greater despotic power than an administration based purely on the shariab and ensured that the state remained the organisational centre for responding to issues of social change. ${ }^{32}$

"Developed in large part as a response to the relationship between the beys [local landowners] and central authority", these decrees, or kanuns, were particularly associated with Mehmed II's (1444-1446 \& 1451-1481) attempts to keep control of newly-conquered lands. ${ }^{33} \mathrm{~A}$

${ }^{28}$ In Al Mugaddimah this essentially nomadic quality, which becomes corrupted by the experiences of urbanisation leading to social chaos before eventual resurgence, is the basis for Ibn Khaldoun's cyclical account of human civilisation.

${ }^{29}$ See Berkes, N. (1974) p. 295.

${ }^{30}$ Berkes, N. (1974) p. 294.

31 Shaw, S. (1976) p. 134. The ulemas' fatwas were, of course, not always acted upon by the Sultan and his advisers. If ignored, however, there was a significant risk of a Sultan losing some of the Caliph's all important legitimacy and fomenting resistance among the influential pious.

32 Halil Inalcik notes that this was augmented by the adoption of the Hanifi school of jurisprudence which, he argues, is "characterised by its broader principles to allow the state to introduce measures to cope with newly arising problems" (1968, p. 22).

${ }^{33}$ Karpat, K. (1973) p. 32. My emphasis and parenthesis. 
controversially un-Islamic example of his confiscation of much of the empire's agricultural land from the old Selçuk landlord/military classes. $^{34}$ These were redistributed as ttmars, providing "the government with a crucial means of maintaining some control over the most important economic resource, namely the land, and also over the largest segment of the population, the peasantry". ${ }^{35}$ They were administered by seyfiyye cavaltymen, the sipabi, who collected taxes on the state's behalf, ensured that the land was continuously cultivated and, in time of war, supplied men and resources proportional to the estate's value and revenue. ${ }^{36}$ In keeping with their status as 'slave' to the sultan, the sipabi were prohibited from marrying until retirement, not able to pass their land on to their children and could be removed from post at any time. ${ }^{37}$ As part of the vertically organised hierarchy of the askeri, they thus represented the central authority of the state at, as Table Two shows, a diffuse village level. Together with the ulema, the sipabis formed an administrative layer "locally reproducing the political and ideological functions of the state". 38 This militarising aspect of the political-ideological contact between state and peasant, however, also provided a potentially decentralising means of interaction between reaya and askeri. As Mann points out in illustrating the thitd of his channels of ideological power, this was a particular problem in Rome where "the army was the main means by which ordinary people, usually peasants, were removed from the cultural prison of their locality and brought into contact with the wider world". ${ }^{39}$ By contrast, in the Ottoman empire the strongly pacifying and immanent effects of the state's ideological omnipresence prevented the temporary tmmariot recruits from developing both the transcendental cults, such as Mithraism, and the

\footnotetext{
${ }^{34}$ The traditional teaching of Islam tends to emphasise strongly the rights of private property.

${ }^{35}$ Karpat, K. (1974) p. 89.

${ }^{36}$ It has been estimated that by 1475 there were 22,000 sipabis in Anatolia and 17,000 in Rumelia . Each time a Sultan was enthroned these were reshuffled to prevent them merging with civil society and constituting a decentralised intermediary class (Anderson, P., 1993, pp 368-369).

${ }^{37}$ See Karpat, K. (1973) pp 32-36.

38 Islamoğlu, H. \& Keyder, Ç. (1987) p. 48. Their emphases.
} 
tendency to merge with civil society which Mann identifies as features of the Roman legions.

Table Two: Askeri 1545-1659.40

\begin{tabular}{|lcccccccccc|} 
& Town & $\%$ & Country & $\%$ & $\begin{array}{l}\text { Un- } \\
\text { known }\end{array}$ & $\%$ & Total & $\%$ & Converts & $\%$ \\
\hline Janissaries & 258 & 78.8 & 58 & 17.7 & 11 & 3.5 & 327 & 21.3 & 127 & 38.8 \\
Sipabi & 509 & 77.4 & 129 & 19.6 & 19 & 3.0 & 657 & 43.9 & 158 & 24 \\
Ulema & 327 & 93.1 & 19 & 5.4 & 5 & 1.5 & 351 & 23.4 & 33 & 9.4 \\
Palace & 50 & 87.1 & 6 & 10.5 & 1 & 1.8 & 57 & 3.7 & 23 & 40.3 \\
Officials & & & & & & & & & & \\
Craftsmen & 93 & 83.7 & 16 & 14.4 & 2 & 1.9 & 111 & 7.6 & 30 & 27.0 \\
Total & 1,237 & 82.1 & 228 & 15.4 & 38 & 2.5 & 1,503 & 100 & 371 & 24.6
\end{tabular}

This was supported by the state's interventionist approach in the economy. As such, artisans and peasants were assisted in favour of merchants and landlords in keeping with the Caliph's traditional obligation of bisba, the surveillance of public morals. The movement and sale of produce was closely controlled by the askeri, oligarchies were disbanded, sipabis and other landowners were restricted in what they could extract from their labourers, riba (usury) was punished in the shariab courts and any excessive wealth generated from trade investments could be seized by the state. As Halil Inalcik notes, "confiscation was employed particularly against the farmers and officials who had made their money through their connections with the Finance Department". ${ }^{41}$ In this way, the state maintained an authoritative influence over its agents and, in intervening on the grounds of Islam to protect the predominantly peasant consumers, was able to minimise the possibility of an intermediary class

\footnotetext{
${ }^{39}$ Mann, M. (1986) p. 311.

${ }^{40}$ Source: Faroqhi, S. (1994) p. 551, after O. Barkan.

41 Inalcik, H. (1969) p. 107.
} 
developing between the askeri and the reaya. Further restraints on wealth generation were imposed by a prohibitively high exportation tariff of 12 per cent aimed at ensuring that Ottoman traders, already constrained by the limitations of pre-modern transportation, did not develop extensive networks of economic power. ${ }^{42}$ In this way, the pre-sixteenth century imperial economy consisted largely of selfsufficient production units (estates, farms, manors, etc.) trading predominantly with the state. This lack of interdependence, imposed by institutionalised restrictions on social status and the infra-structural reach of the state's military-ideological power networks, constitutes what Mann (after Durkheim) identifies as a "segmental class system" in which no "societal-wide producing class capable of enforcing its interests politically" emerges. ${ }^{43}$ Unlike in Rome, where the economic might of the senatorial class, coupled with its extensive territorial and cultural unity, obliged the imperial state to rule through an intermediary body, the Ottoman system ensured that no such universal ruling class could develop..$^{44}$

The close proximity of the askeri to the mechanics of economic production, distribution and consumption provided a carefully monitored extensiveness to this "cellular" system. It relates, in some ways, to Mann's reworking of Herbert Spencer's model of the 'military society' which, he argues, was most apparent in Rome's "legionary economy". This employed an enhanced method of "compulsory co-operation" aimed at facilitating a more thoroughly institutionalised system of imperial domination. Of the five methods Mann outlines, described briefly in Chapter Two, the first, "military pacification" through the institutionalisation of "monopolistic rules conferring ownership and governing exchange established and

\footnotetext{
42 Owen Lattimore estimates that animals used to transport food would have to eat the contents of their loads every 100 miles (1962, pp 476-485). Diocletian's price edict doubled the cost of a wagon-load of wheat every 300 miles making maritime transport the only economically viable method of long-distance transportation (Finley, M., 1973, p. 128). For further data, see Bailey, F. (1942) p. 79.

${ }^{43}$ Mann, M. (1977) pp 269-270.
} 
maintained internally by an authoritative state", 45 was clearly in place through the sipabi's influential position, both legitimising and enforcing regulation in the economy. With other members of the armed forces (the seyfiyye), they also subjugated challenges to peripheral trade routes, enforced the re-distributive decisions of the ulema's judiciary and played an important geo-political role in monitoring international trade with the other regional actors. The second, "the military multiplier" effect, can be seen operating in the Ottoman economy as agricultural production and supply, largely managed by the sipabi, became increasingly geared towards the needs of a permanent, professional army, the janissary corps. Apart from consumption, the seyfiyye also stimulated regional economies by initiating infra-structural projects such road and castle building and improving riverine networks. Indeed, Rhoads Murphey concludes his study of the construction of a fortress in Mosul in 1631 by noting that,

"if one considers the economic stimulus provided locally in supplying the needs of the army in the provinces, not only in the provision of its daily needs such as grain or in the maintenance and repair of equipment giving employment to blacksmiths, leather-workers and a multitude of other trades, but also in larger terms by its acting as an employer of labour on a grand scale for the digging of trenches, building of roads and bridges, and the construction of fortresses, the army's economic impact was not inconsiderable". 46

Thirdly, the fusion of "authority and economic value" was typified by the authoritative power of the askeri, particularly the ulema and their network of kadis (judges), in ascribing financial legitimacy based on the shariab and the orf. Here, the rigidity of the ideological-political union acted as a restraint upon the stimulatory effects of the militarised economy showing that the state and not the market remained the pre-eminent Ottoman organisational form. The

${ }^{44}$ Defined by Mann as "an economic class that has successfully monopolised other power sources to dominate a state-centred society at large" (Mann, M., 1986, p. 25). ${ }^{45}$ Ibid pp 148-149. 
prohibition of riba and excessive profiteering, for example, demonstrate the viewpoint of the policeman rather than the entrepreneur and contrasts sharply with the liberalisation process occurring around this period in the West. There, the rise of capitalism involved multiple and cross-cutting cleavages between various social institutions as church competed with state, provincialism with nationalism and the proletariat with the bourgeoisie. In the Ottoman Empire, however, networks of social interaction "continued to be defined by a primary axis dividing the state from all social strata rather than by multiple axes dividing social strata from one another". 47

The fourth element of Mann's model, the "intensification of labour", or the degree to which the militarised imperial state can increase labour productivity, can be seen on both sides of this state/subject divide. The state's ownership of much of the empire's arable land, coupled with the complex integration of religious and military agency, meant that the sipabi could, in most cases, easily be coerced into surrendering a greater tribute. The extent to which these pressures were passed on to the peasantry was carefully monitored through the empire's juridical infra-structure allowing the state to adjust the levels of surplus extraction and labour intensity according to its needs. In urban centres the artisan guilds were similarly closely affiliated to the supervisory apparatus of the central administration. ${ }^{48}$ In controlling the supply of raw materials, restricting the sale of finished goods to authorised markets and suppressing independent competition, the state closely regulated the guilds' structure, both in terms of their output and capital accumulation. 49 "Through the taxation of manufactures sold in the markets, and through its position as the chief purchaser of artisanal production", 50 the state was thus coercively and collectively able to maintain control over labour intensity as well as ensure that its agents, the askeri classes, constituted

\footnotetext{
${ }^{46}$ Murphey, R. (1980) p. 169.

47 Bianchi, R. (1984) pp 87-88.

48 See Stern, S. (1970) and Baer, G. (1970). For an alternative view, Lewis, B. (1937).

${ }^{49}$ See İnalcik, H. (1970) pp 216-217.
} 
the only significant surplus-collecting social group. Supported by an immanent ideology centred upon "the beneficence and justness of the state which... owns all the land and redistributes the surplus in order to perpetuate the 'eternal order", 51 it also meant that the extensive links of the artisan classes, Mann's fourth channel of ideological power, ${ }^{52}$ could not escape the organisational reach of the state's judicial and tax-collection system.

Indeed, the taxation of the reaya by the askeri was one of the state's primary means of applying its own extensive power and extending infra-structural control across its territory. As Mann has pointed out, taxation, as a method of economic integration, gave imperial states much stronger vertical links with its citizens than a rental system (which tended to favour a de-centralising landlord class) or a tradebased economy implying greater horizontal integration and further de-centralisation. ${ }^{53}$ In the absence of a banking system, wealth redistribution was controlled exclusively by the state through its own mechanisms of disbursement. As such, coinage was not primarily regarded as a method of exchange between citizens, but rather as means of paying state expenses, particularly armed forces expenditure. In what Mann calls "military Keynesianism", 54 the state reduced the rural population's need for money by encouraging tax payment in kind and by administering revenues through the provinciàl tumar system which minimised the need to transfer large sums of money to the centre. 55 Such constraints furthered the Ottoman state's supervisory position within the economy and maintained the social divide between potential economic success and political influence. While it was still expanding, there could be no Crassus in the Ottoman empire. Wealth and status could only "exist in isolation from power, as among the commercial and religious

\footnotetext{
50 İslamoğlu, H. \& Keyder, Ç. (1981) p. 303.

${ }^{51}$ Keyder, C. (1976) pp 181.

52 Mann, M. (1986) pp 312-313.

53 Ibid. p. 271.

54 See Mann, M. (1984) p. 204.

${ }^{55}$ See Pamuk, Ş. (1994) pp 952-953.
} 
notables of the subject classes; or else they might be secondary attributes of power, distributed along with it to the more exalted of slave officials". ${ }^{56}$

\section{Ottoman Change}

As has often been noted, the Ottoman state's systems of "military organisation, civil administration, taxation, and land tenure were all geared to the needs of a society expanding by conquest and colonisation". ${ }^{57}$ When this came to a halt in Vienna in 1529, leading to a century and half of inconclusive warfare with the Habsburgs, it began a slow decline in both despotic and infra-structural power. Once the frontier became stationary, peripheral communities began trading across the border and developed decentralised networks of economic power thereby modifying their allegiance to the state. ${ }^{58}$ The provincial seyfiyye, deprived of the spoils of conquest required to legitimise their position, were unable to intervene, particularly in the predominantly non-Muslim northern and western periphery where the state's ideological reach was less comprehensive. ${ }^{59}$ This became particularly acute following the collapse of the Ottoman silver-based currency under pressure from Spanish-American imports and the shift in trade routes from trans-Ottoman to maritime channels. Increasingly unable to pay their troops, the Ottoman state permitted the seyfiyye to work as artisans while barracked. As a result, decentralised economic networks of power came to replace the authority of the military hierarchy and troops merged with the merchant classes of garrison towns, particularly during the wheat shortages of the second half of the sixteenth century, while still benefiting from their tax-exempt status. ${ }^{60}$

\footnotetext{
56 Findley, C. (1980) p. 15.

${ }^{57}$ Lewis, B. (1961) p. 27.

58 See Owen Lattimore's research on imperial China (1962) p. 470. He writes, "Men of both border populations, working together in this way, become a 'we' group to whom others of their nationality, and especially the authorities, are "they"' (ibid.).

59 See Andreski, S. (1971) pp 20-74.
} 
The reduction in the value of cavalry compared to musket-bearing infantry led to further substantial increases in the size of the seyfiyye, particularly the standing army (the janissary corps) which was enlarged from 7,886 men in 1527 to 37,627 in 1610 and re-deployed from their traditional barracks in Istanbul to "all sectors of the empire". ${ }^{61}$ To support the more defensive, labour intensive infantry formations, ${ }^{62}$ large numbers of mercenaries, sekban, were also recruited pushing up the total number of imperial troops from 21,519 in 1528 to 88,382 in 1670 and increasing the cost from 58 million to 237 million aspers over the same period. ${ }^{63}$ This militarisation of the periphery, coupled with the rapid spread of fire-arms, offered decentralised social networks a more intensive means of organisation. ${ }^{64}$ It was exacerbated by the increasing competition between the sipabi and the janissaries, particularly over tomar allocation, which, following the desertion of 30,000 sipabis from the battlefield at Hacova in $1596,{ }^{65}$ led to a proliferation of decentralised armed groups (celali) and to great social instability. ${ }^{66}$ The rigid divide between askeri and reaya was under threat. Military power networks, always extremely extensive, had burgeoned under the strategic imperatives of the state's geopolitical commitments and, through decentralised economic links, had begun to constitute an intermediary class between subject and state. The 'three-way stand-off in which neither arbitrary nor consultative relations structure the relationship between central and local levels, so apparent in Mann's characterisation of the decline of Rome, ${ }^{67}$ was developing in the early

${ }^{60}$ See İnalck, H. (1994) pp 182-185 and Coles, P. (1968) pp 168-169.

61 Inalck, H. (1994) p. 24. Yücel Ozkaya, however, puts the figure much higher; at 40,000 in 1550 and 100,000 in 1600 (cited in Sunar, I., 1987, p. 71). See also Inalck, H. (1964) p. 46.

62 See Mann, M. (1986) pp 453-458.

${ }^{63}$ Karpat, K. (1973) p. 35.

${ }^{64}$ See İnalcak, H. (1975) p. 211.

${ }^{65}$ See Karpat, K. (1974) pp 89-90.

${ }^{66}$ These rebellions were not, as some have argued peasant revolts of the European feudal ilk. Although they included peasants who had fled the military/fiefdom or those that were loyal to a dispossessed sipabi, they were essentially the actions of organised groups of minor gentry whose target was not superior feudatories, but representatives of state authority. See Mardin, Ş. (1967) pp 131-133, for a fuller account.

${ }^{67}$ Mann, M. (1986) p. 282. 
seventeenth century Ottoman polity. Like Diocletian (284-305), who was similarly troubled by great rises in the cost of warfare, the Ottoman state attempted to increase its revenues. ${ }^{68}$ The tmar system was thus largely replaced by a system of tax-farming. ${ }^{69}$

Under the new system, arable plots were leased for one or two years to the highest bidder who paid in advance for the right to exploit the land and sell the produce as he saw fit. Although this had the primary aim of enlarging the productivity, both in yield and tax revenue, of the arable estates, it was also intended to reduce the entrepreneurial influence of the increasingly propertied and irredentist sefizye. Crucial to this structure, however, was the state's infra-structural capacity to prevent the tax-farmer from forming, through collective organisation, tax-evasive and reciprocal economic links with the peasantry, a consideration hardly helped by the system of stipulatory advance payment which favoured those with considerable liquid assets and therefore established economic networks invisible to the state. The increasingly fragmented askeri hierarchy did not offer the state the necessary infra-structural reach to monitor the relationship between tax-farmer and peasant with sufficient rigour. Without this, the state was not able to keep control of civil society's economic power networks, nor did it succeed in preventing the 'leakage' of both authoritative power and resources. Civil society's inherent tendency to wrest and decentralise infra-structural resources from the state, which, as Mann notes, is reinforced by the mutually beneficial developments of compulsory co-operation, ${ }^{70}$ began to overtake the Ottoman state's despotic capacity to maintain its hierarchical system of control. For "while tax-farming provided the state with an immediate source of revenue, in the long-run it led to erosion of its tax base, since the flow of taxes upward to the centre became increasingly subject to the

${ }^{68}$ Ibid. pp 289-295.

${ }^{69}$ The 63,000 tmars of 1475 were reduced to 7,000 by 1630 . See Karpat, K. (1973) p. 35, after Inalcik.

${ }^{70}$ Mann, M. (1984) pp 205-206. 
interference of the tax-farmers". ${ }^{71}$ By handing the peasantry and the market over to the tax-farmer, the Ottoman state sacrificed a significant amount of its capacity to both intercede on behalf of the reaya and control economic exchange. In all, "a process of feudalisation and a rise in the strength of the local gentry" was the result. ${ }^{72}$

These notables, around a thousand of which dominated the taxfarming auctions at Istanbul throughout the eighteenth century, ${ }^{73}$ emerged predominantly from reaya positions such as wealthier artisantraders (esnaf), traditional community leaders (esraf), landed families (derebeys or forbaçis) and tribal chiefs (ağas). They were, however, also joined by significant numbers of kadis, tax-collectors from different commercial fields, sipabis, janissaries and defterdars (local treasury officials). Both reaya and askeri viewed tax-farming as a way of investing profits which otherwise might be seized by the state. As a result, the previously rigid social divide between them became blurred and to some extent fused in the form of the new intermediary economic class. This became known as the ayan once their roles became generally connected to tax-farming towards the end of the eighteenth century. While most remained embedded in statedetermined structures of revenue acquisition, some ayan organised more extensive economic links and began to act as agents between the state and less consequential families (of whom, many were taxfarming on the estates, or siftliks, of the ayan elite themselves).

The state, having been further strained by again failing to take Vienna in 1683, was powerless to prevent the development of an increasingly decentralised economy. The surrenders at Carlowitz and Passarovitz in 1699 and 1718 respectively, followed by the first major concessions of Muslim land in Küçük Kaynarca in 1774, severely weakened both

\footnotetext{
71 Sunar, İ. (1987) p. 70.

72 Mardin, S. (1967) p. 133.

${ }^{73}$ See McGowan, B. (1994) p. 662.
} 
its fiscal and ideological position in relation to civil society. ${ }^{74}$ No longer was the 'normative pacification' of its ideological-political cohesiveness able to regulate the market and re-distribute wealth. The earlier shortages of specie which had assisted the state in maintaining a grip on currency transactions had been reversed by the influx of cheap silver form the New World. The treasury's devaluation measures were successful in lowering the price of domestic products, but failed to offset the lucrative incentives of surreptitious exportation created by the prohibitively high tariffs on international trade, from which the ayan elite profited significantly. ${ }^{75}$ This led to stagnation in the crafts industries, great pressures on fixed income earners and further incorporation into the Western economic system. Indeed, the 'Capitulations' system, which was initially aimed at simply conferring the autonomy of the millet upon foreign traders, had, by this time, burgeoned exponentially, constituting, once its privileges became hereditary, a huge tax-exempt class of foreign protégés impeding the development of an indigenous capitalist middle-class. ${ }^{76}$ In all, "the combination of tax-farming and its resultant weakening of state controls on production, and the increasing concessions to foreign merchants and its resultant weakening of state controls on trade created a set of centrifugal forces that undermined the basic authority of the Porte".77 Put another way, the state's capacity to correlate authority and economic value, the third of Mann's strategies of compulsory co-operation, was becoming increasingly impaired.

These economic upheavals, the effects of which the state was now powerless to prevent being passed on to the reaya, added greatly to the instability within the Ottoman agricultural system. Sekban militia, often supported by groups of destitute countrymen removed from the

\footnotetext{
74 See Karpat, K. (1972) pp 245-251.

75 See Sunar, I. (1987) pp 69-74 and Chandler, R. (1971) p. 73. Salonika was, for instance, heavily involved in illegal exportation. There, external trade rose from 900,000 piastres in 1700 to 9,500,000 piastres in 1786 (McGowan, B. , 1980, pp 735736).

${ }^{76}$ Peter Sugar reports that Austria alone certified 200,000 subjects in Moldavia and 60,000 in Wallachia $(1964$, p. 154).
} 
land for non-payment of taxes, worked with provincial governors, a proportion of lesser ayan and the remnants of the sipabis to impose punitive and illegal levies on the peasantry. The state, heavily reliant on this alliance for the supply of revenue, could only look to effecting countervailing changes aimed at limiting the escalating recalcitrance of the fragmenting askeri. This was accentuated by the decline of the ulema's semi-independent political power base. Having been disastrously split by the faqib movement and the Sultan's increasingly despotic use of the orf $7^{78}$ they now lacked the horizontal links of the ayan to whom they turned for assistance. Eventually the ayan elite was largely able to absorb the office of provincial kadi thereby strengthening its position as an interjacent and politically influential body between state and subject. ${ }^{79}$ As tax intermediaries with impunity from the law, they were "able to shelter whole strings of villages from the fisc in return for near total control over village finances". ${ }^{80}$ Indeed, some were even elected by lesser tax-payers to represent their interests to the state and used this position to secure life-long tenure on their estates further weakening the state's capacity to correlate authority and economic value. ${ }^{81}$ As a result, the kadis could no longer ascribe financial value with the authority of an agent of a unified askeri elite. The market now began to usurp the divided state as the primary method of determining economic worth. Riba and excessive profiteering became commonplace within the askeri as the bazaar took on the multiple and cross-cutting cleavages apparent in Europe.

Particularly affected was the ulema. In fusing with the ayan elite, a small group of privileged families within the theocracy emerged who were able to monopolise positions of great influence and conceal

77 Wallerstein, I., Decdeli, H. \& Kasaba, R. (1987) p. 92.

78 This movement vehemently opposed the increasing Western influences at work in the Ottoman empire arguing that much it constituted an illegal bidab (innovation). In attacking the European links and questionable lifestyles of some of the ulema elite, their leader, Mehmed Birgivi, attracted considerable support among the reaya leading to a significant loss of ulema authority, unity and legitimacy (İnalcak, H., 1968, pp 2526).

${ }^{79}$ For a more detailed account of this process, see Inalcak, H. (1977) pp 41-42.

${ }^{80}$ McGowan, B. (1994) p. 662. 
huge wealth. ${ }^{82}$ Consequently, their religious independence was greatly compromised "as a kind of ulema aristocracy developed and merged with the lay aristocracy, abandoning solidarity with the socially inferior ulema".83 This was worsened by the recruitment of 'official' clerics (ulema-resmive) who had purchased their diplomas from the state and were therefore not qualified as an alim. ${ }^{84}$ Religious students (softas) and low to medium ranking ulema, who saw their leaders' apparent corruption and support for the state's pro-European position as a threat to both their religious sensibilities and future employment opportunities, were joined by traditionalist elements of the armed forces in opposing the ulema elite's acceptance of increasing Westernisation. 85 Indeed, "leading ulema not only sanctioned and supported the innovations initiated by the sultans and their military and civil advisers, both Ottoman and European, some of them also played a major role in conceiving, suggesting and planning reforms on European lines".86 Selim III's (1789-1807) chief judge, Tatarcik Abdullah, for instance, vehemently called for the adoption of Western battlefield techniques and equipment through the appointment of European advisers.

This materialised in 1826 when the janissaries were replaced with a more disciplined and reliable standing army closely associated with Western influence. ${ }^{87}$ Following its disastrous performance in the 1828-1829 war with Russia, however, the new military struggled to gain the legitimacy of the seyfiyye's traditional jibadi status. ${ }^{88}$ Moreover,

${ }^{81}$ See Gibb, H. \& Bowen, H. (1957) pp 193-194.

82 Niyazi Berkes comments that during this period "the higher ulema were engaged in extra-curricular activities such as selling offices, degrees ranks and favours, usurious dealings, even in tax-farming and the expropriation of estates, and above all in controlling the pious foundations" (1964 [1998 edition]) pp 61-62.

${ }^{83}$ Levy, A. (1971) p. 14.

${ }^{84}$ See Chambers, R. (1972) p. 34.

${ }^{85}$ See Reed, H. (1980) pp 194-196.

${ }^{86}$ Heyd, U. (1961) p. 64. See also Shaw, S. (1965) p. 294.

87 Hellmuth von Molte, later Prussian Chief of Staff, commented in 1835, while working for Mahmud II, that the Ottoman army had "Russian jackets, French regulations, Belgian weapons, Turkish caps, Hungarian saddles, English swords and instructors from all nations" (cited in Davison, R., 1963, p. 31).

${ }^{88}$ See Levy, A. (1971) pp 30-31. 
with the incorporation of the empire into the world economic system, their role in the military pacification of trade routes (the first of Mann's strategies of compulsory co-operation) also declined. Maritime navigation did not require their presence and, although they remained capable of repressing sporadic civil disorders in the capital and disarming recalcitrant ayan, they proved consistently unable to prevent further imperial contraction. Their domestic influence was further diminished with the secularisation of the justice system during the Tanzimat period (1839-1876) and the creation of a bureaucratic police department away from seyfiyye influence.

Furthermore, the economic stimulus provided by their consumption needs (the military multiplier effect of Mann's second strategy of compulsory co-operation) became increasingly parasitical as overseas contractors, administered by the kalemiyye, undertook more and more of the empire's major construction projects. Moreover, these now predominantly involved wage labour thereby further diminishing the need for a coercive military presence in order to improve productivity. Similarly, since the dissolution of the timar system, they neither had an active role in agricultural production nor in military recruitment, particularly after the introduction of conscription in 1843. Indeed, the presence of non-Turkish conscripts within the professional army for the first time made the last of Mann's compulsory co-operation methods, coerced diffusion, extremely problematic. Since barely one-third of the peasantry spoke Turkish, the language and culture of the centre could no longer be transmitted to the imperial periphery through the standing seyfiyye. ${ }^{89}$ While the cultural extensiveness of the officer corps endured, their ability to socialise the peasant-infantry below them was curtailed.90 This undermined the immanent legitimacy of the state and, without

\footnotetext{
${ }^{89}$ Rustow, D. (1964) pp 357-358.

${ }^{90}$ Quataert, D. (1994) pp 798-823.
} 
offering an alternative structure, ruptured the cohesiveness of the seyfiyye's ideological function. ${ }^{91}$

Indeed, the prior unity of ideological and political power which had proven so important to the maintenance and legitimacy of the state's coercive influence in the past had, by the beginning of the Tanzimat period, significantly changed. Not only had the ulema and the seyfiyye lost their vertical cohesion and much of their legitimacy, the political effects of changes to the kalemiyye, or scribal service, had further weakened the state's ideological infra-structure. Traditionally educated through the Palace School's broad and humanist curricula, ${ }^{22}$ these civil servants were long associated with the 'worldly' intellectual pursuits, or the adab.93 During the eighteenth century the kalemiyye became increasingly politically active providing the basis for six Grand Viziers between 1703 and 1774 and institutionalising considerable support for the pro-Western reformers. ${ }^{94}$ Selim III further developed their influence by re-structuring the organisation along European bureaucratic lines and appointing civil servants to the newly-established embassies of the major European capitals. ${ }^{95}$ Closely associated with the centrality of state, the kalemiyye also gained a greater role in education provisions which were seen by the Ottoman elite as "the prime agent for accomplishing the aims of Westernisation". 96 To this end, the örf was used to remove responsibility for primary schooling from the offices of the seybülislam in 1824 and to set up a ministry of education under bureaucratic

\footnotetext{
${ }^{91}$ As the contemporary statesmen Ahmed Cevdet observed, "In Europe, indeed, patriotism has taken the place of religious devotion, but this has happened at the end of their feudal period; their children hear the word 'fatherland' while they are still small, and so years later the call of patriotism has become effective with their soldiers. But among us, if we say the word 'fatherland' all that will come to the minds of the soldiers is their village squares. If we were to adopt the word 'fatherland' now, and in the course of time, it were to acquire the power that it has in Europe, even then it would not be as potent as religious zeal, nor could it take its place". Cited in Lewis, B. (1961, p. 332).

${ }^{92}$ See Miller, B. (1941) Ch. 4.

${ }^{93}$ See Findley, C. (1980) pp 9-12.

${ }^{94}$ See Itzkowitz, N. (1962) p. 89.

${ }^{95}$ See Findley, C. (1970) p. 355.

${ }^{96}$ Kazamias, A. (1966) p. 52.
} 
control in 1838. New secular schools, complemented by Westernorientated military colleges, were established to train an administrative elite and to provide the basis for a secular intelligentsia. ${ }^{97}$ Graduates of these establishments did indeed became an influential clique who were able to dominate the legislative councils and key bureaucratic positions for much of the nineteenth century. ${ }^{98}$ In all, the "civilbureaucratic elite that assumed political pre-eminence in the era of reform took a leading role in altering, or even abandoning various elements of the traditional synthesis [of state and religion]".99

The Ottoman state, however, failed to make the bureaucracy subordinate to the political system and was thus unable to turn administrative modernisation into infra-structural power. Rather than avowedly neutral and entrusted with the best interests of civil society, the politicised kalemiyye came to dominate the askeri classes. As Peter Sugar puts it, "the expanding bureaucracy became increasingly centralised, its power being wielded by a steadily diminishing number of persons within it". ${ }^{100}$ The process of structural and functional differentiation, strongly emphasised during the Tanzimat, was not accompanied by a flexible value system as the centralising state associated itself with secular modernity and civil society with Islamic traditionalism. ${ }^{101}$ Instead, the centre's "preoccupation with saving the empire from destruction by its internal and external enemies led to a constant, and often exaggerated, fear of anarchy, rebellion and treason as a leitmotif of modernising Turkish statecraft". ${ }^{102}$ The resultant attempts to establish a direct relationship between state and peasant through the Gülbane Rescript of 1839 and the Reform Edict of

\footnotetext{
97 See Weiker, W. (1968) p. 460 . New naval and infantry engineering schools had been set up in 1773 an 1793 respectively which, from 1827 onwards, started dispatching students to various European countries for further training. In 1831 the Imperial Music School, Murika iHmayun Mektabi, was founded and in 1834 the School of Military Sciences, Mektebi Ulumi Herbiye. See Lewis, B. (1961) Chs. 3 \& 4 and Karpat, K (1973) pp 44-45.

${ }^{98}$ See Shaw, S. (1970) passim.

${ }^{99}$ Findley, C. (1980) p. 11. My parenthesis.

100 Sugar, P. (1964) p. 157.

${ }^{101}$ See Bellah, R. (1968) pp 188-189.

102 Bianchi, R. (1984) p. 91.
} 
1856 (which declared the equality of all Ottoman citizens) can therefore be seen as more an effort to appease the Western powers while organisationally outflanking the ayan in the nizam tradition than a recognition of the inalienable rights of man. ${ }^{103}$ These re-centralising endeavours, supported by further efforts at land reform in 1858 (Land Code) and 1864 (Province Law), increased the powers of regional governors appointed from the kalemiyye and were widely regarded as reinforcing the bureaucratic state's own despotism. As a result, they provoked considerable opposition from the Turkish peasantry and outright rebellion amongst non-Turkish groups. ${ }^{104}$ Such polarisation, coupled with the decentralised economic elite's enduring ability to resist the bureaucracy's interest in taxable agriculture, meant that the decline in provincialism, visible in much of Western Europe during this period, did not occur in the Ottoman empire.

A fundamental cause of the state's inability to apply the reforms of the Tanzimat was that the ideological channels it required to appeal to the peasantry over the heads of the class of provincial elites had, particularly in the periphery, fractured irrevocably. The previously ulema-controlled political communication channel of Caliph to peasant was now taken up by bureaucratic networks whose infrastructural capacity, while horizontally extensive within urban elite networks, was too limited to offer the state the same degree of vertical integration. This meant that unofficial transcendentalism, as an organisational alternative to the statist immanence of the centre, became increasingly significant as the nineteenth century wore on. ${ }^{105}$ As such, non-statist clerics, particularly those in the periphery, were able to utilise their long-established extensiveness to marshal what

${ }^{103}$ See Heper, M. (1985) pp 39-40 \& Mardin, S. (1960) p. 425.

${ }^{104}$ Kemal Karpat argues that these measures proved more oppressive than the old ayan's control of the peasantry and so "people found it more congenial to follow their own communal leader" (1972, p. 263).

${ }^{105}$ For instance, the Kuleli incident of 1859 in which around forty theological professors and army officers conspired to overthrow the state on the grounds of its contravention of the shariah. Roderic Davison notes that this event "provides a good index to widespread Turkish attitudes. It revealed... [a] condemnation of the 
Eisenstadt describes as "free-floating resources" outside state control.106 In contrast to the largely 'Turkified' urban elite, the influence of these sheikhs, as leaders of the Sufi brotherhoods such as the enormous Qadiriya and Naqsbbandiya, "began to extend far beyond the spiritual sphere" gaining acceptance not just from their own order, but also from the general public. ${ }^{107}$ In 1880 , for instance, the Naqsbbandi leader, Ubaidullah, was able to de-centralise enough political power to give him de facto control of the region of Nihri and a basis from which to launch a large-scale rebellion. ${ }^{108}$ Significantly though, his target was not agents of the state, but local competitors which the recent Treaty of Berlin (1878) had appeared to favour. ${ }^{109}$ In this sense, then, the ideological channel of cultural tradition, previously so rigorously controlled by the infra-structure of state, was now more representative of the growing competition between intraperipheral groups. ${ }^{110}$ In other words, the failure of the state to institutionalise new ideological methods of linking its apparatus to civil society reduced both its capacity to prevent political-ideological status being determined by decentralised civil forces and its ability to maintain ideological cohesion within its own political hierarchy.

Alternative organisational forms thus began to emerge within the bureaucracy itself. The expanding education system, which trebled the

government both for its reform edicts and its apparent submission to foreign influences" (1954, p. 861). My parenthesis.

106 For the relationship of the ulema with the traditional periphery, particularly in south-east Anatolia, during this period, see Yeğen, M. (1996) p. 219 and Eisenstadt, S. N. (1969) passim.

${ }^{107}$ Kreyenbroek, P. (1993) pp. 95. For a general account of Sufi heterodoxy, see Kissling, H. (1954) passim.

108 Around 50,000 attacked the non-Sunni communities of the Urumiya plain, immediately displacing at least 10,000 people. The conflict was eventually suppressed amongst immense bloodshed by a combined Ottoman and Persian force after the majority of Ubaidullah's forces had gone home with their spoils.

109 The Berlin Treaty offered protection to the Armenian community (Article 61) and was seen by many of the neighbouring social groups as "a stepping stone... towards the emergence of an independent Armenian state" (McDowall, D., 1992, p. 56).

110 Kemal Karpat supports this arguing that once the Tanzimats legislation had replaced the protected status of millet with inapplicable notions of citizenship, "the relative position of the religious and ethnic groups within the Ottoman Empire began to be decided on the basis of their numerical strength" leading to "mutual interference and oppression" (1982, p. 163). 
literacy rate during the last quarter of the nineteenth century, ${ }^{111}$ had empowered both the state and civil society - offering each a means of autonomous infra-structural power. It also constituted what Mann terms a 'potentially dislocating' ideological channel of communication through which a challenge to the state can be organised. As such, it was around the novel, the play and the newspaper that opposition to the Tanzimat reforms coalesced. ${ }^{112}$ In contrast, the state failed to use the expanding paper media to explain its policies and defend its actions, preferring instead, particularly following Ali Pasha's decree of 1867 , to suspend and repress publications containing unfavourable comment, ${ }^{113}$ a policy much extended under the reign of Abdul Hamid II (1876-1909). Through Namik Kemal's play Vatan (Fatherland), Ziya Pasha's novel Intibab Yabut Sergïzesti Ali Bey (Awakening or Ali Bey's Adventures) and the newspaper Basiret (Insight - published sporadically from 1869 to 1879), ${ }^{114}$ the Young Ottomans, many of whom had been trained in the Mülkiye or other elite schools, called for restrictions on the despotic power of the state and a return to a romanticised vision of the empire's once-great glories. ${ }^{115}$

Namik Kemal, for instance, argued that the favourable position of non-Muslims through the millet and Capitulations systems was socially divisive and discriminatory and therefore un-Islamic and illiberal. ${ }^{116}$ The abolition of these would, he contended, lead to a rational and 'modern' conception of group loyalty replacing the ancient idea of religious affiliation with the more immanent focus of the Ottoman vatan. In keeping with their close affiliation to the centre, the Young Ottomans were also strongly opposed to the enduring and, as they saw it, retrogressive influence of the provincial economic elites arguing

\footnotetext{
"11 See Lewis, B. (1961) p. 455.

112 See Mardin, S.. (1961).

${ }^{113}$ See Davison, R. (1987) pp 22-23.

114 For a discussion of the role of this publication, see Mardin, Ş. (1989) p. 123. For a broader account of the media during this period, see Karpat, $\mathrm{K}$ (1964a) pp 257 267.

115 See Szyliowicz, J. (1971) and Kuran, E. (1962) p. 427.

116 These points gained particular credence during the evacuation of Muslims from Belgrade and Crete in 1867. See Davison, R. (1954) pp 863-864.
} 
that their support amongst the peasantry was due to the ongoing failure of the bureaucracy to fully modernise; in other words to represent civil society along Western infra-structural lines. ${ }^{117}$ Herein, however, lay the problem for the Young Ottomans. The decline of the ulema as the primary medium of the state's 'official' communication channel meant that the ideology of the centre could be imperialised no more. The Young Ottomans therefore failed to extend their vision of citizenship, despite the infra-structural potentials of the new literary media, outside their coterie of leisured ideologues.

The Young Ottomans' inability to connect their self-contradictory pastiche of nationalism, pan-Islamism and Western liberalism to the provinces became apparent following the overthrow of Sultan Abdul Aziz in 1876.118 Although within the subsequent constitution, which Namik Kemal and Ziya Pasha helped to draft, a notional concept of Ottoman 'citizenry' (without religious affiliation) was inscribed, ${ }^{119}$ the monarchic prerogative, and therefore state absolutism, remained unrestricted. This was demonstrated immediately in the dismissal of the seybülislam, Hayrullah Efendi (who had legitimised the dethronement of the Sultan) and the relegation of his office to the council of ministers. ${ }^{120}$ Worse still for the reformers was the elections of 1877 which, with only members of provincial councils enfranchised, filled their long-requested parliament with influential provincial notables and middle-ranking ulema from the periphery. ${ }^{121}$ The elected deputies' did not, therefore, espouse the ideology of Young Ottomanism, but rather focused their criticism on the centrist bureaucracy which, it was claimed, caused backwardness in

117 Writing in the newspaper Hürriyet (April $5^{\text {th }}$ 1869) Ziya Pasha commented that "the [municipal] councils established after the Tanzimat in each town had as members the notables, that is to say, the old derebeys, who took the title of councilmen. While in the past it was possible to punish them [derebeys] severely... now the councilmen and clergy in each town have been oppressing the people several times worse than the old derebeys" (cited in Karpat, K, 1972, p. 263, his parentheses, my emphases).

118 See Mardin, Ş. (1962a) p. 179.

${ }^{119}$ See Arai, M. (1991) p. 3.

${ }^{120}$ See Mardin, Ş. (1989) pp 124-125 and Findley, C. (1980) pp 224-227. This decree in part provoked Ubaidullah's rebellion. 
"agriculture, commerce, arts, science [and] all other matters of public interest". ${ }^{122}$ So much so that Abdul Hamid abandoned the idea in February 1878 in favour of a programme of Islamically legitimised administrative reforms aimed at reinforcing state authority over the bureaucracy and "thus eliminating any form of political activity not directly under his control". ${ }^{123}$

However, despite greatly increasing the numbers of staff employed by the central bureaucracy, heaping honours on those deemed of influence and developing a sophisticated system of despotic terror, ${ }^{124}$ the kalemiyye continued to fragment. This was particularly compounded by substantial remuneration disparities between favoured and disfavoured bureaucratic offices and the commonplace use of summary dismissals, both of which significantly reduced morale and efficiency. As promotion and recognition became associated only with cronyism and titles sank in general esteem, the bureaucracy faltered and lost more of its cohesion. ${ }^{125}$ This was worsened by the failure of the state to pay the interest on its debts of $£^{200}$ million in 1881 leading to the establishment of the Public Debt Administration ${ }^{126}$ which institutionalised the position of European finance capital and limited the bureaucracy's control over the appropriation and utilisation of its revenues. ${ }^{127}$ Thus it lost much of its authoritative control at both a horizontal state level and, as the social gap between ruler and ruled further widened, in terms of its

121 See Devereux, R. (1963) Ch. 6.

122 Cited in Karpat, K. (1972) p. 269. For further analysis of parliamentary debate during its only two sessions, March 19 to June 281877 and December 131877 to February 14 1878, see Karpat, K. (1969) passim. My parenthesis. Carter Findley comments that the parliament "displayed a level of independence, capability and procedural orderliness that astounded contemporary observers and subsequent historians - perhaps unduly, given the prominence among the deputies of the same sort of notables who had dominated the local assemblies created during the Tanzimal" $(1980$, p. 226).

${ }^{123}$ Findley, C. (1980) p. 234.

124 Such as the pro-Westem sheikh Jamal al-Din Al Afghani who was highly decorated by the Sultan between 1894 and 1897 in an attempt to reinforce the palace's ideological legitimacy. See Deringil, S. (1991) for a more detailed account.

125 This also affected the armed forces where student protests at even the most prestigious military schools became commonplace.

126 The PDA is examined in detail in Blaisdell, D. (1929) passim. 
ability to link state and civil society. In all, the state's attempts to strengthen its infra-structural reach over its agents and to outflank the emerging concert of interests between the provincial elites and disaffected elements within the civil service failed.

Indeed, the decentralised power of this alliance was significantly aided by a considerable expansion in the export economy during Abdul Hamid's reign. ${ }^{128}$ Provincial traders turned great profits (so much so that the officially bankrupt administration gained enough revenue to begin borrowing again) out of exports such as tobacco, opium, silk and wool leading to the appearance of a nascent Muslim middleclass. ${ }^{129}$ Still largely deprived of political function by the omnipotently status-determining state superstructure, however, they were not, as Feroz Ahmad points out, "a bourgeois class that exercised any significant political influence on the state". ${ }^{130}$ Thus the tension inherent in being an economic stake-holder denied of comparable political status, long a cause of separatist sentiment within the millets, became apparent within the emerging Muslim trading elite. Moreover, unlike the more segmental, or what Ilkay Sunar calls "disarticulated", 131 structure of non-Muslim export commodity production, this new entrepreneurial class was not disassociated from its broader socio-political context by intensive links with foreign powers. As the result, the expansion of the bureaucracy (which increasingly obliged the elite schools of the centre to enrol students from outside their traditional clique) ${ }^{132}$ offered these provincial elites an opportunity to establish a foothold in the political centre as well as to gain "a degree of professional specialisation [which] created the conditions for selectivity and stratification among the intelligentsia and produced eventually a political ideology and a leadership

\footnotetext{
127 See Wallerstein, I., Decdeli, H. \& Kasaba, R. (1987) p. 94.

128 See Clark, E. (1974) passim. For an account of this seemingly paradoxical situation of boom and bankruptcy, see Keyder, Ç. (1980) passim.

129 See Pamuk \$ (1987) pp 150-151.

${ }^{130}$ Ahmad, F. (1980) p. 329.

131 Sunar, I. (1987) p. 83.

132 See Kazancigil, A. (1981) p. 46.
} 
group". ${ }^{133}$ By the 1880s, opposition to bureaucratic centrism coalesced around five students of the Mekteki Tibbiyeri Askeriye (Military Medical School) all of whom originated from the imperial periphery. ${ }^{134}$ Thus the leadership of the Ottoman Society of Union and Progress (Osmanli Ittrbat ve Tarakke Cemiyettr), or so-called Young Turks as they became known, represented, from the outset, provincial opposition to the imperial state. In many ways, the emergence of this organisation, which will be examined in more detail in the following chapter, marked the beginnings of more than fifty years of intensive ideological power contention which was ultimately to result in the end of the Ottoman empire and the institutionalisation of a republican nation-state.

\section{Conclusion}

The extensive power of the Ottoman state's territorial claim was based on the unity between ideology and politics and, as such, was the primary mechanism through which newly acquired conquests were assimilated and governed. It provided the structure and the means to join the periphery to the centre. Embellished by the orf, it maintained a polity of sufficient adaptability to systematise highly diverse indigent groups as well as directly linking them to the state thereby staying organisationally ahead of civil society's inherent tendency to decentralise power and spawn a ruling or intermediary class. In this sense, Islam provided the state with a more comprehensive and intensive socialisation mechanism than the Roman method of governing through a local ruling elite imbued with the cultural values of the centre. The combination of ör and shariab offered the Ottoman state a more socially inclusive structure of governance than the Roman ruling class society, in which Mann argues "only the elites were admitted into real membership". ${ }^{135}$ The original

${ }^{133}$ Karpat, K. (1972) p. 277. My parenthesis.

134 A Circassian, an Albanian, two Kurds, and an Azeri. See Shaw, S. \& Shaw, E. (1977) pp 255-259.

135 Ibid. p. 296. 
transcendentalism of Islam's message was transformed by the military success and political symbolism of the Ottoman Caliph into an immanent ideological infra-structure flexible enough to absorb, or at least administer, the socially heterogeneous periphery. Structured by the omnipresent askeri hierarchy, the Ottomans' political-ideological monism thus gave the imperial state a level of territoriality hitherto unattained.

This calls into question Mann's assertions regarding the exceptionally high levels of pre-modern infra-structural power the Roman empire possessed Indeed, if, as Mann contends, state power consists of the "centralised, institutionalised, territorialised regulation of many aspects of social relations", then the presence of a "partly decentralised" social group within the legionary economy would seem to limit significantly Rome's claim to territoriality. ${ }^{136}$ In a dialectic not apparent within the Ottoman administration, the Roman state was, on the one hand, unable to gain centralised control of the intermediary class's socio-economic networks of power, but, on the other, such a decentralised structure could not flourish without the state's military role in the legionary economy. So, while the institutionalisation of a common ruling class culture was key to Rome's functional longevity, it proved too territorially limited to control the appropriation of social status within civil society. In other words, by allowing local elites to develop a political capability beyond their economic power base, the state was forced to govern through a senate of provincial aristocrats.

Table Three: The Contradictions of Imperial Rule

\begin{tabular}{|l|l|}
\hline 1 & Universalism versus Particularism \\
\hline 2 & Decentralisation versus Centralisation \\
\hline 3 & Civilisation versus Militarism \\
\hline 4 & Equality versus Hierarchy \\
\hline 5 & Cosmopolitanism versus Uniformity \\
\hline
\end{tabular}

136 Ibid. p. 26 \& p. 280. 
Since state function was so uni-dimensionally military in character and fundamentally reliant on decentralised social networks, the Roman empire was not, it seems, a territorial empire in the Ottoman sense. The ideological channels which Mann identifies within the Roman imperial polity, bound the ruling class together through a secular culture transmitted by a combination of Latin and Greek literary links, but were largely beyond the reach of the state. Without an integrated ideological function, and an economy controlled by an independent intermediary class, Mann's portrayal of the Roman's state's political claim to territoriality is largely based around a military role within the framework of compulsory co-operation. In contrast, the Ottoman state's organisation of social power was more multifaceted. Unencumbered by such a decentralised challenge, it owned the empire. Neither within the manufacturing economy nor as part of agricultural production was there the "three-way power standoff" between the state, its agents and an established intermediary class. ${ }^{137}$ While these decentralising tendencies are an inherent factor in imperial rule and one that is crucial to an understanding of the decline of Rome, as it is to the decline of the Ottoman empire, its manifestation is not made inevitable by the weakness of imperial infra-structural power. So long as it continued to expand, the Ottoman state was able to allocate sufficient resources to its military-ideological-political super-structure to prevent such challenges emerging, even within its periphery. This gave it a political function and a despotic, autonomous territoriality not simply based on a monopoly of coercive force. Its extensive network of clerical, military and commercial agents added a comprehensive and statist political-ideological dimension to civil society's social networks at a very intensive level. Moreover, unlike Mann's depiction of a horizontally unified ruling class in Rome, the askeris strongly vertical organisational nature was continually reinforced by comprehensive systems of state intervention. Few within the Ottoman administration could read, no empire-wide lingua franca existed and, apart from fiscal records undertaken by treasury

337 Ibid. pp 280-282. 
officials, written communication was rare. In all, the multi-ethnic, poly-lingual and non-stratified askeri could not be considered a universal ruling class in the form that Mann sees as a feature of Roman social organisation.

Of the four ideological channels which Mann identifies within the Roman imperial polity, three - the authoritative/official, the armed forces and the artisan - were heavily circumscribed by the Ottoman state's networks of ideological power. These provided a means of resolving the contradictions of imperial rule, set out in Table Three, which, Mann argues, the Romans had been unable to do. ${ }^{138}$ So long as the Ottoman state maintained control over these, channels, particularism was weak as no hereditary aristocracy could challenge the universalism of the Caliph's ummab. ${ }^{139}$ Nor could it develop organisational alternatives to the centralised position to the state which, unlike Rome, did not lack 'real' infra-structural power. The complexity and comprehesiveness of these networks ensured that civilisation and militarism were kept apart. State-controlled normative structures could absorb and govern newly-conquered communities through economic and ideological linkages without the need for perpetual military coercion. By the sixteenth century, this had established a system of vassal states, never fully subjugated, covering extensive areas of central Europe, the Hijaz and the Caucuses. In both the periphery and the core, social status was too heavily controlled by the state to permit a political challenge to the ideologically 'natural' hierarchy of Sultan to peasant thereby organisationally outflanking claims to egalitarian citizenship. This verticality obviated the need for an official uniformity thus the fourth channel of ideological power, the cultural traditions of localised networks such as regional languages and shared beliefs, which, as Mann points out, "could communicate unaided only over small

138 Ibid. pp 306-307.

139 By political extension this fellowship also included, administratively at least, Jews and Christians as the Qur'anically defined abl-ul kitab (people(s) of the book). 
spaces", ${ }^{140}$ was either ignored or tacitly promoted by the Ottoman state as a means of strengthening the cosmopolitan 'segmentalism' of the reaya. ${ }^{141}$

Figure Three: Changes in Ottoman Ideological Channels of Communication

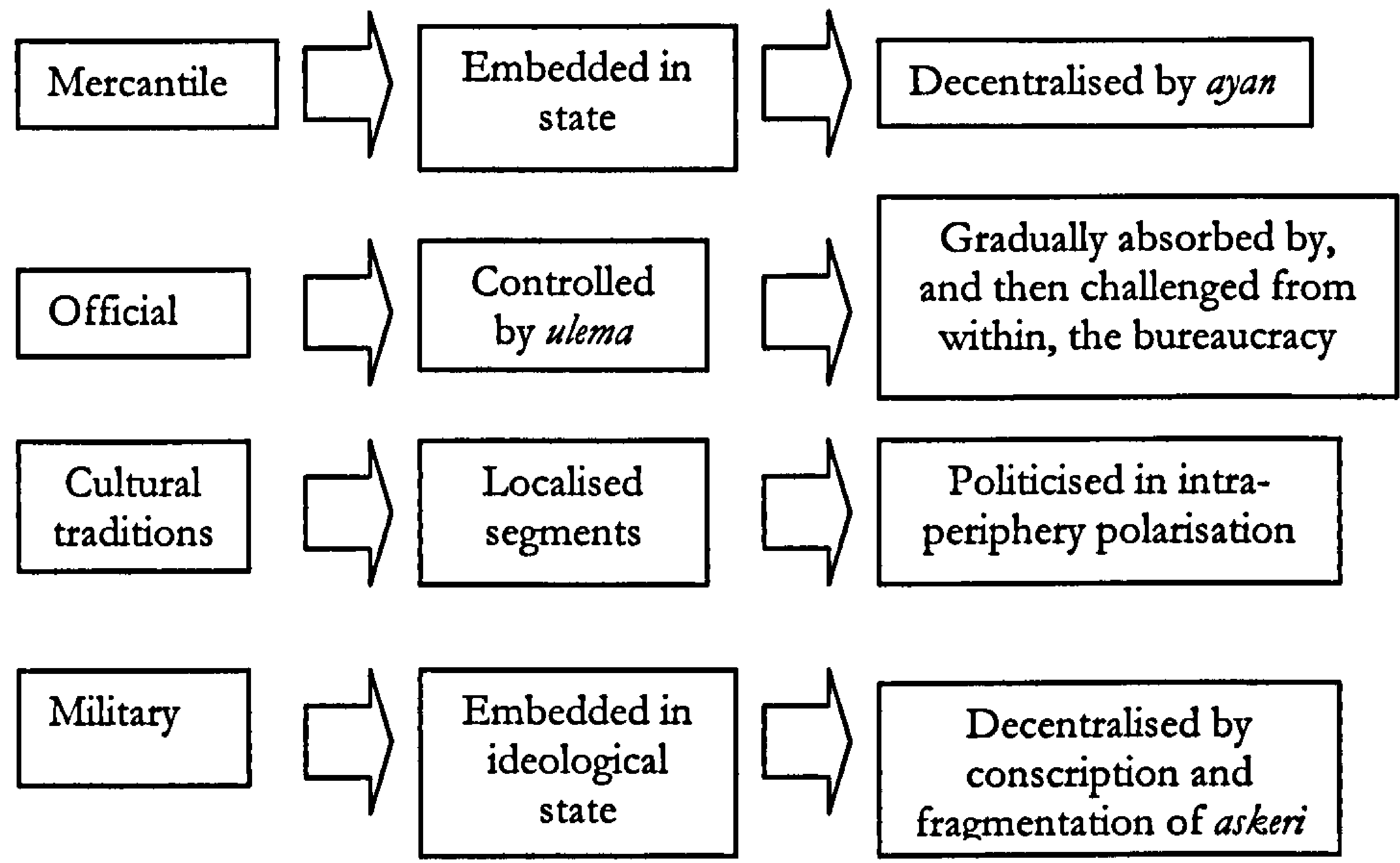

Once the Ottoman state's capacity to infra-structurally support its position as the only arbiter of ideological legitimacy and political function diminished during the nineteenth century, however, contradictory interstitial trends similar to those in Rome emerged within these channels. As Figure Three illustrates, particularist patrimonialism became commonplace within state agencies as the traditional divide between askeri and reaya gave way to more decentralised socio-economic groups. Utilising the official channel of the state bureaucracy and the nascent literacy networks existent within sections of civil society, the Young Ottomans and then the Young Turks institutionalised, firstly, an elite and, secondly, a provincial challenge to further centralisation. This diminished the religious proto-nationalist efficacy of the ulema without institutionalising a

140 Ibid. p. 311

${ }^{141}$ For example in the millet system. 
viable alternative. As a result and in contrast to Western patterns of social change, the state's infra-structural reach diminished. Concurrently, the ayan were able to increase their influence over mercantile channels of ideological communication within the periphery eventually decentralising a limited amount of political power and thus, by the early nineteenth century, taking on many of the characteristics of a semi-extensive intermediary 'class'. As a result of the expansion of the state's bureaucracy, they were able to build on these provincial network to gain a foothold in the educational establishments of the core.

Figure Four: Changes in Ottoman Compulsory Co-operation

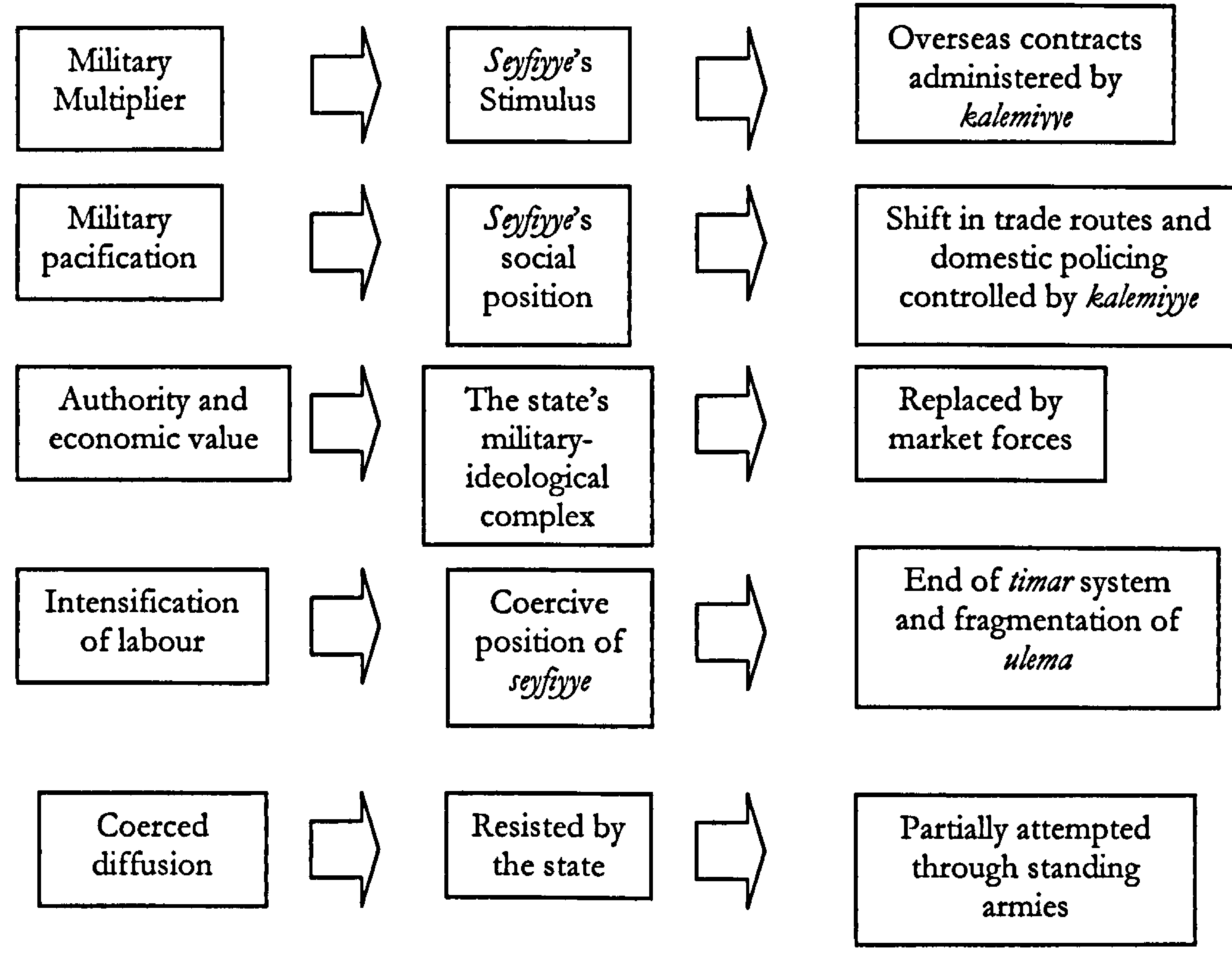

Now more marginal to the state's centralised control, the military's ideological channel also became increasingly subject to decentralising influence. Previously embedded in the ulema's immanent organisation of state power, Western-style bureaucratisation and successive defeats weakened their ability to transmit the ideology of the centre to the 
periphery. Overlapping with the military's communication channel, was the state's capacity to regulate the cultural traditions of the provinces. While expanding, the imperial centre was generally able to ensure that these intra-peripheral networks remained localised and intensive. Increases in the standing army, coupled with the growing power of both local elites and foreign agents, however, eventually brought about an intensification of these cultural channels and a rise in intra-peripheral conflicts largely beyond state control. In all, despite lacking the horizontal extensiveness necessary to challenge the systemic position of the state, such decentralising networks within the empire's ideological channels of communication were able to exploit wider social changes occurring during this period and establish organisational alternatives to the imperial super-structure. They provided the basis, or in Mann's terms 'laid the tracks', for the disassembly of segmental cosmopolitanism in favour of a nationalstate Gesellschaft.

The decline of the state's supervisory position, the rising influence of the West and the growing strength of decentralised market forces also meant that compulsory co-operation, as a method of imperial domination, could no longer form the basis of Ottoman territoriality. As Figure Four illustrates, the military multiplier effect was reduced as the state bureaucracy, and then overseas contractors, increasingly administered centrally-planned infra-structural enterprises. The military's pacifying function was also reduced as trade linkages shifted away from trans-imperial routes and towards the greater cost effectiveness of maritime transportation. Bureaucratisation also diminished their role in the domestic repression of the reaya as 'modern' police systems acquired civil authority. Within the bazaar, the state's military function similarly changed. The ulema/seyfiyye's military/ideological complex was no longer required to correlate authority and economic value as the decentralised market forces of international capitalism gradually became the empire's primary economic organisational form. With the end of the trmar system, 
neither was the state's military input into state extraction necessary. The emergence of the ayan as a semi-extensive, decntralised economic class prevented military agents of the state from gaining direct access to the peasantry. As a result, the exploitation of the reaya was more dependent on local elites and international economic forces than on the 'repression as benevolence' of compulsory co-operation. Elements of coerced diffusion were, in response, used by the state as an attempt to re-impose their authority. Within the standing armies which replaced the sipabi system, for instance, technological advances were extending to provincial outposts, but without sufficient restrictions on their agents status and wealth accumulation (plus the ideological fragmentation brought by conscription), the state was unable to prevent these from merging with elite groups within the reaya. In all, the collapse in the Ottoman version of compulsory cooperation meant that, while the state's emphasis on political change in the inkalab tradition ensured that most decentralised power networks generally remained segmental and disarticulate, the three-way standoff, which according to Mann's was inherent in all pre-modern empires, began to appear.

While much of this analysis represents a new, and occasionally contradictory, addition to Mann's general theoretical framework, his model remains illuminating. Having highlighted many of these contradistinctions, it is important to emphasise that the institutionalisation of social power within the Ottoman empire constitutes, in many ways, a refinement of Mann's construction of the methods of imperial domination and ideological organisation rather than a refutation. This is particularly the case as the Ottoman state's capacity to support its position declined and the empire took on the more decentralised characteristics apparent in Mann's treatment of earlier empires. In all, this account of Ottoman continuity and change suggests that Mann's macro-historical approach provides an appropriate and profitable means of analysing and comparing patterns of large-scale social reorganisation. Thus both Mann's theoretical 
composition and his diachronic exposition will be used to look at the end of the empire and the establishment of the Turkish republic in the next chapter. 


\section{Chapter Four: The Ideology of Modernism}

This chapter looks at the ideological basis of Turkish nationalism. It will focus on three key areas of Mann's historiographic model, namely ideological power's inherent characteristics, the development of nonreligious modes of social explication and what he terms the rise of 'proto-nationalism' in north-western Europe. Considered first, will be the social origins and growth of modernism in the late Ottoman empire and its effects following the First World War. Important areas of development here are the importation of Western concepts of post-Enlightenment rationalism, language reform and changes in educational provisions. Secondly, the origins of 'Turkism' will be traced and compared to Pan-Islamic and Pan-Ottoman alternatives current in the thinking of the bureaucratic and military elites of the late Ottoman period. Thirdly, the post-imperial emergence of ethnocentrism will be looked at in relation to policies pursued during the 1914-18 war and in the early years of the Turkish republic. The extent to which these were successful in the narrowing of the Ottoman centre/periphery divide will be examined with particular reference to legislation enacted during the 1920 s.

\section{Mann's Model of Ideological Power}

Mann outlines seven generally applicable reorganising, or 'tracklaying', achievements of ideological power. ${ }^{1}$ As Table Three illustrates, the first was the resolution of the contradictions of Roman imperial rule in favour of univeralism, egalitarianism, decentralisation, cosmopolitanism and civilisation. The Ottoman Empire was, however, not so prone to these contradictions as Rome. Its organisation of ideological power, particularly through its control of literacy (a second tracklaying achievement), generally provided civil society with an infra-structure that was universalist, cosmopolitan and

1 Mann, M. (1986) pp 363-371. 
normatively civilising. The empowering effects of compulsory cooperation and the spread of a 'two-step structure of literacy' (in which written messages were carried by key individuals within each locality and then passed on verbally) during the nineteenth century, however, led to an increase in decentralised and egalitarian ideological power networks in opposition to the Ottoman state. In this sense, then, power contention in the latter part of the nineteenth century and early twentieth century was focused more on the state's highly centralised and hierarchical social infra-structure than on networks of particularism, enforced uniformity and militarism.

Table Four: Tracklaying Achievements of Ideological Power

\begin{tabular}{|l|l|}
\hline 1 & The Resolution of the Contradictions of Imperial Rule \\
\hline 2 & The Control of Literacy \\
\hline 3 & The Extension of Social Identity \\
\hline 4 & The Narrowing of the State-Subject Divide \\
\hline 5 & The Capacity to Supersede Existing Structures \\
\hline 6 & The Control of Core Social Spheres \\
\hline 7 & The Development of Military Morale \\
\hline
\end{tabular}

A third tracklaying achievement was ideological power's capacity to transcend existing social structures by extending personal and social identity across gender, ethnic, class and state boundaries. Its emphasis on what Mann calls 'the fundamental questions of existence', of interpersonal ethics and of familial relations expanded the collective power of diffused mutualised belief systems. Operating with other power networks, this tended to break down localised social structures, such as the 'cultural traditions' of the millets, and, in ideology's fourth tracklaying achievement, to bring the masses closer to state. The inherent transcendency of ideological power could, in other words, be immanently employed to mobilise support for new or established 
social structures. Where ultimate meaning was located outside the existing economic, military and political structures, such support intensified specifically ideological networks of power. This fifth tracklaying achievement was important to the Ottoman state as a means of both conquering and absorbing new territory.

Ideological power is not autonomous, however. Its sixth tracklaying achievement, the near-monopoly of control over 'core social spheres' such as cosmology, ethics, familial relationships and the life cycle, remained intensive and reliant on alternative power networks for territorial extensiveness. Islam, for example, was not only diffused by clerics, but also by traders and soldiers. Indeed, the relationship between ideological networks and military morale, a seventh tracklaying achievement, has been an enduring organisational connection and fundamental to the success of Ottoman expansion. For Mann, though, its legitimatisation of violence tended to reduce the universalism of the third achievement. Ideological networks have, moreover, largely failed to impose universalist notions upon other macro-power structures such as gender and class dominance further reducing their power autonomy. In Europe, Christianity simultaneously provided a transcendent classless ideology which was extensive and pacifying enough to stimulate trade and a social immanence reinforcing the existing production relations of the Roman hierarchy it had inherited. As Mann concludes, "religions did not so much transcend existing power organisations as parallel them". 2 During the early medieval period, these consisted of two authoritative hierarchies of bishopric and monastic social networks administered by their own judiciaries and supported by a revenue systems coexistent with those of secular institutions. Like the ummabCaliph relationship, it afforded a basis for social identity broader than that of any other power source and provided a framework for other divisions such as class and literacy. Pilgrimage to the Levant or the Hijaz broke down intensive, localised power relations and broadened

2 Ibid. p. 367. 
integrative ideological and trading links. This was instrumental in extending the 'normative pacification' of the Christian and Muslim ethic which, with its greater complexity and efficiency than simple coercion, became "the main guardian of civilisation" for both the ecumene and the ummab. ${ }^{3}$

For Mann, such extensiveness was obvious at four levels. Firstly, at a regional level the Church co-ordinated campaigns against banditry and overly exploitative agricultural and trading practices. In a similar process to the Ottoman ulema's administration of the Caliph's obligation of bisba (the guardianship of public morals), the Church's organisation of legitimacy was both more intensive and infrastructurally more extensive than that of political, economic and military units. Secondly, at a political level the bishops and abbots supported the rule of the monarch with sacral authority and literate clerics in a structure comparable to that of the Ottoman theocracy. Thirdly, the papacy, like the Caliph, was an important arbiter of interstate relations. Few monarchs would resist their influence and risk excommunication from Rome or a condemnatory fatwa from the seybülislam. Fourthly, on an inter-continental level the Church coordinated the defence of Christendom and the victory in the Holy Lands. Later, Istanbul, too, was able to raise armies in defence of the ummab and as guardian of Al-Kaba, Al-Madina and Al-Aqsar.

How then did the tracklaying extensiveness of the Christian fellowship and the Caliph-led ummab come to an end? In approaching the European question, Mann suggests four forces based around economic growth which, in a movement assisted by the literate classes (including the Church itself), eventually led to the secularisation of the ecumene. ${ }^{4}$ The first, the development of scientific rationality, was a particular problem for the papacy. Endowed with a greater interpretative role than the more exegetically constrained

3 Ibid. p. 382 [he refers only to Europe].

4 Ibid. pp 463-472. 
Muslim theocracy, the Church had elaborated "a complete set of cosmological doctrines that were central to its imperial legacy of authority, but that were hardly central to original Christian dogma". ${ }^{5}$ In responding with repression to the suggestion that these might be refutable, the Church polarised the division between faith and reason. This enlarged the area of debate from issues of natural history into the Church's 'core spheres' of social explication. The Ottoman organisation of Islam, with its greater theological delimitation between matters of belief (taqwa) worship (ibada) and societal relations (muamalaat) generated a less authoritative grip on issues of cosmology. Both the comprehensiveness of Islam's early analytical texts and its rejection of vicarious atonement devolved only limited interpretative powers to the ulema and therefore offered the believer an autonomy quite different from the subjects of Christendom. This meant that significant scientific and mathematical advances, as well as rigorous social commentaries, ${ }^{6}$ could be undertaken without provoking a comparably despotic response. Indeed, as discussed in the previous chapter, it was only when the Western conflict between religion and science had informed and exported emergent forms of consciousness, such as the frameworks of class and nation, during the nineteenth century that challenges to the Ottoman ideological super-structure emerged with any significant power.

A second secularising force within both the ecumene and the ummab was that of emergent capitalism. Once the market started to replace the Ottoman state as the principal organisational form within the imperial economy the tension between a centralised ideological authority and the decentralised decision-making required by capitalist exchange, apparent in Europe since the middle ages, also began to emerge. Similarly, the institutionalised restraints on status legitimised by the Church in Europe and the ulema in the Ottoman empire were at odds with the imperatives of commodity production in which, as

\footnotetext{
${ }^{5}$ Ibid. p. 464.

6 For a survey of the more prominent of these, see Faroqhi, S. (1999) Ch. 6.
} 
Mann notes, "nothing apart from property ownership is given a fixed and authoritative status".7 In contrast to the Ottoman state's emphasis on bisba - the surveillance of public morals - and the importance of intervening on behalf of the peasantry, capitalist value allocation offers no intrinsic worth to labour beyond its exchangeability with other elements of production. Furthermore, capitalism's logic of continual reinvestment differed from the wealthy believer's social obligation to maintain a large household, give alms (or sadaga) to the poor and provide extensive local employment opportunities. As such, entrepreneurial forces found little ideological support in the established orders of the late medieval ecumene and the Ottoman empire of the nineteenth century. Instead, the fledgling bourgeoisie of both societies turned towards more apposite meaning systems which, through decentralised literary networks, better expressed their normative solidarity.

The third and fourth secularising forces of the ecumene were based in the geopolitics of Europe. The navigational revolution of the fifteenth century, which in Mann's view was instrumental in the uniquely swift economic advance of north-western Europe, brought great increases in trade to the Ottoman Mediterranean ports. These, like those of the Atlantic and Baltic seaboards, became centres of mercantile interaction at the edge of the ideological centre's infra-structural reach. While in Europe, the geo-political effects of this could be quickly seen in the rapid politicisation of Luther's protest of 1517, in the Ottoman empire it was not until Muslim mercantile groups from western Anatolia began significantly investing in international trade in the nineteenth century that shifts in regional economic power became a potential means of ideological decentralisation. The segmental nature of the millet system, which had ensured that the ideological channel of 'cultural traditions' remained localised and intensive without the organisational power to infiltrate the more extensive

\footnotetext{
7 Mann, M. (1986) p. 465
} 
networks of 'official' communication supervised by the ummab, 8 proved highly susceptible to what Mann calls the 'proto-nationalist' forces of a divided and politicised Christendom. Although socially embryonic and primarily apparent in the Protestant states further west, the gradual emergence of the national-state in the aftermath of the wars of religion was a powerful influence across the continent. This, the fourth of Mann's secularising forces, eventually became an important element in the Ottoman state's loss of ideological legitimacy.

The 'religious' proto-nationalism which emerged from sixteenth century Protestantism and the Catholic Counter-Reformation, was the first of five 'phases' of nationalist development identified by Mann.? Three of these will be outlined here. The fourth and fifth, the 'industrial capitalist' and 'modernist' phases, emerged following the Turkish industrialisation and urbanisation processes of the 1950s and thus will be looked at in the following chapters. There were two elements, Mann suggests, to the pre-modern 'religious' protonationalism of the late-Renaissance ecumene. The first was the Church's ability to spread the vernacular of the centre through its domination of literary networks. This increased the efficacy of the state's 'official' ideological channel and, in displacing local dialects, reduced the intensity of localised social networks in favour of broader, more extensive perceptions of identity. In the Ottoman empire, this effect was uncommon as the language of the centre was saturated with classical Arabic and Persian and therefore generally unintelligible to the reaya. The Ottoman ulema's educational and social infra-structure which trained state officials and, until the nineteenth century, largely controlled the elite's discursive literary networks in fact often represented an obstacle to attempts at standardisation and dispersal of a common language. The second was the tendency of the Church to organise popular support for the geo-political conflicts of the state.

\footnotetext{
See Mardin, Ş. (1960) p. 380.
}

9 See Mann, M. (1993) Ch. 7. 
While discernible in the wars of religion, this was somewhat restricted by the ecumene's still essentially trans-national character. The ulema, too, continued to be constrained by its own universalist creed and the cosmopolitan nature of its constituency.

Table Five: The Media of Commercial-Statist Proto-Nationalism

\begin{tabular}{|l|l|}
\hline 1 & The Standardisation of Military Texts \\
\hline 2 & The Education of Administrators by the State \\
\hline 3 & The Development of Universities not under Church Control \\
\hline 4 & Trade-Based Literary Links \\
\hline 5 & The Legal Profession \\
\hline 6 & Printed Media \\
\hline 7 & Discussion Centres \\
\hline
\end{tabular}

From around 1700 onwards, Mann argues that a second, pre-modern phase of proto-nationalism began in Europe. The secularising forces of emergent capitalism institutionalised a form of 'commercialstatism' in which, as Table Four illustrates, discursive literacy expanded outwards from the Church through seven principal media eventually providing the basis for modern nationalism. ${ }^{10}$ Both Protestantism and Catholicism had, from the sixteenth century onwards, encouraged Bible reading and the writing of simple tracts leading to increases in signing literacy in much of Europe. From this foundation, discursive literacy emerged firstly from standardisation of military texts in keeping with the large increases in armed forces expenditure during the seventeenth century. ${ }^{11}$ Secondly and thirdly, the literacy of higher state administrators also moved away from Church control as universities took on wider educational roles.

${ }^{10}$ Here, Mann's categories of literay and periodical media are collapsed into 'printed' media. Ibid. pp 35-43.

"Mann writes that military manpower had reached 5 per cent of the total population in many states by the end of the eighteenth century (1993, p. 37). 
Fourthly, commercial networks, particularly in trading occupations and regions, developed literacy links based on marketing, accounting and contractual arrangements beyond the reach of the Church. Linking these two forces with the ideology of the state, the legal profession emerged as a fifth medium, doubling in size in most eighteenth century European countries. Sixthly, the expansion of printed media during this period extended both religious and secular discursive literary networks enhancing the transcendentalism of decentralised ideological discourse. Lastly, discussion centres such as taverns, libraries and coffee-houses emerged as centres of organised readership well away from the influence of the Church and its emphasis on family life. All these media diffused a secularised literate culture downward from the old regime leading to what Mann identifies as a rudimentary shared notion of civil citizenship.

The growth in militarism during the nineteenth century challenged trans-national elements within proto-nationalism and institutionalised the cross-class, state-linked characteristics of modern nationalism. By around 1840, Mann argues that this militarism had helped to produce three forms of 'quasi' nation-states. ${ }^{12}$ Mainland Britain and France, he suggests, were examples of a national consciousness that reinforced state boundaries. In Prussia, pan-German sentiment had begun to institutionalise a state creating form of nationalism and in Austria group identities tended to be based on units contained within the sovereign totality and therefore state subverting. While economic networks assisted in these processes by stabilising identities and expanding literacy over large areas of Europe, it was not until later in the nineteenth century that they began to encourage what Mann calls "a distinctively national civil society". ${ }^{13}$ Initially, he argues, militarist nationalism was centred on the expansion and centralisation of political networks. Through taxation and conscription, states imposed a greater extractive demand upon civil societies in order to support

12 Ibid. p. 218.

"1 Mann, M. (1995) p. 47. His emphasis. 
their geopolitical commitments within a global arena increasingly defined by military prestige and territorial competition. Since the dominant classes of Europe were better able to establish organised resistance to such demands, the expanding pressures of the state were regarded by civil society, particularly the bourgeoisie and petite bourgeoisie, as a process of retrogression. As a result the 'protonational' discursive media of the 'commercial-statist' phase became imbued with the ideology of political citizenship based on exclusive notions of 'the people'. Male, bourgeois citizens from the dominant religious and ethnic groups defined themselves as a nation to which the state should be coterminous. The militaristic features of these sentiments were intensified by fears of populist radicalism exacerbated by the French Revolution and the Napoleonic Wars. ${ }^{14}$ In all, Mann concludes that "self-conscious nations emerged from the struggle for representative government, initially born of the pressures of state militarism". 15

\section{Science, Language and Education}

Calls for representative government in the Ottoman empire also emerged from the pressures of militarism. The discursive networks of Young Turk modernism apparent in the 1890s had their origins in the elite military academies modelled on the European nation-states. ${ }^{16}$ Their emphasis on rationalism and pro-Westernism was, however, much older. A science of reason, born of a traditional interest in Classical Greek learning, had long prompted endogenous critical analyses of Islamic state-craft. Ottoman writers worked in the internationally-known tradition of Ibn Khaldoun's exposition on Abbasid society and political sociology. Lufti Pasha, for example, was already warning of an unpromising future characterised by growing social inequity and threatening maritime states to the west as early as

14 Britain, for example, committed an unprecedented 31-43 per cent of her GNP to this conflict with France (Mann, M., 1992, p. 153).

is Ibid. p. 48. 
1541. ${ }^{17}$ By 1630 commentaries on Ottoman collapse were meticulous and damning. With what Bernard Lewis calls, "sombre detail and astonishing frankness", 18 Kochu Bey's Risale pointedly attributed Ottoman enfeeblement to palace intrigue, corruption within the askeri and the decline of the tmar system. A century later, Ibrahim Müteferrika argued in Usul ul-Hikam fi Nizam ul-Ümam (Rational Bases for the Politics of Nations) that the Ottoman Empire failure to adopt European methods of governance and scientific exploration was the root of its inability to compete geo-politically. With the patronage of Sultan Ahmed III (1703-1730), this was complemented by treatises discussing Descartes' theory of vortices and Galileo's treatment of Aristotelian physics. ${ }^{19}$ By the time of Sultan Selim III's reign (17891807) Western innovations were an institutionalised and ongoing element of Ottoman political change. As well as being aimed at appeasing the European powers and attempting (ultimately unsuccessfully) to exclude the ayan from political influence, these measures were also intended, perhaps primarily, to reverse the military fortunes of the empire. Each element of a triangular relationship between the bureaucratic state, the military and provincial elites possessed its own vested interests in further Westernisation legitimised by what Ergun Özbudun calls the "Islamic modernism" of pro-European clerics. ${ }^{20}$ In this sense, many Ottoman scholars began to focus on the contradictions of Ottoman imperial rule in ways similar to those deployed by late-Roman Christian theocrats. Since the Ottoman imperial system provided a structure that was, nominally at least, universalist, cosmopolitan and normatively civilising, the ideology of pro-Western intellectualism increasingly emphasised greater equality and decentralisation.

\footnotetext{
${ }^{16}$ This highly disparate and often contradictory movement can only be considered as sharing a general unity in its opposition to "an arbitrary and fantastic Sultan" (Blind, K, 1896, p. 832).

17 Asafname (The Book of Asaph)

18 Lewis, B. (1973) p. 203.

19 See Berkes, N. (1964) pp 36-47.

20 Ozbudun, E. (1984) pp 25-33.
} 
Two thinkers particularly influential on the development of late Ottoman self-reflection generally and Young Turk ideology particularly were the Egyptian Muhammed Abduh (1849-1905) and the Iranian ${ }^{21}$ Jamal al-Din al-Afghani (1838-1899). Both argued that there was no distinction between Islam and human reason and emphasised the importance of ijibad (individual reasoning) in the interpretation and application of the Qur'an and the Sunnah in the modern era. Afghani also argued that "what the prophet received through inspiration was the same as what the philosopher could attain by use of reason".22 However, such rationalism was, he continued, unlikely to appeal to the masses who were still dominated by the dogma of less scientific approaches. It was therefore up to a small, sagacious elite to guide the ummab away from the obscurantism of madbab-dominated jurisprudence towards a purer basis for 'group solidarity' (al asabiyya). For Abduh, too, how to instil a popularly held 'common will' without fomenting fanaticism (ta'assub) was also a recurring theme. In a journal published with Al-Afghani in Paris in 1884 and in his later work, Abdul argued that the principles of Islamic leadership should be grounded on the rational ethics of representation, consultation and accountability found within an enlightened understanding of the shariab. $^{23}$

Such ideas of religion and science's commensurate properties significantly influenced thinkers prominent in the early development of opposition to Abdul Hamid's government. Elements of this 'modernism' can be observed in each of the three major factions that Niyazi Berkes identifies within the pre-revolutionary Young Turk movement. ${ }^{24}$ For instance, Ahmet Riza (1859-1930), a former employee at the Ministry of Education, established a following through his journal Mecbveret (Consultation) associated with French

${ }^{21}$ There is considerable controversy surrounding Jamal al-Din's place of birth. Nikki Keddie convincingly argues his claims to be from Afghanistan (hence the epithet) were based on his desire to present himself as a Sunni (Keddie, N., 1972).

22 Cited in Hourani, A. (1970) p. 123.

23 See Kerr, M. (1966) pp 129-152.

24 Berkes, N. (1964) pp 304-313. 
positivism and the work of Auguste Comte. ${ }^{25}$ In 1896 and 1897 he wrote seven memoranda to the Sultan arguing that "there is no means of saving the country... other than education and the positive sciences".26 Insisting that the shariab obligated the Caliph to promote such societal betterment through representative mechanisms, he called for the restoration of the 1876 constitution and further 'Ottomanisation'. Led by the Daghestani, Murad Bey, a former professor at the Mlekebi Mülkiye (Civil Service Academy), a second group emerged around the publication Mizan (Balance). They, too, pointed to the limitations that the sbariab imposes upon the Caliph, but, unlike Riza's Parisian coterie of Westem favourites, they also maintained a strongly anti-European line. Based in Cairo, Murad and his associates called for a pan-Islamic "Board of Supervisors that would have the power to repel the encroachment of government... and, thus, to cnsure quality and fraternity between the nationalities".27 The third element was led by Prince Sabahaddin, a nephew of the Sultan, who after flecing to Paris in 1898, developed a diagnosis of Ortoman problems inspired by the work of the French social scientist, Frederic Le Play. With an instrumentalist approach to religion similar to that demonstrated by Riza and his followers, Sabahaddin's group argued that W'estern experts should be employed to implement a programme of educational reforms aimed at moving Ortoman socicty away from its collectivist identity towards a egalitarian, individualist model. This, it was suggested, could be best achieved with a substantial decentralisation of state power to local government level.

None of these approaches considered the notion of 'Turkish' collective identity. Their objectives were to reduce nationalist irredentism and prevent further losses of imperial territory. Riza and Sabahaddin's unit of analysis was the Ottoman empire as a whole, while Mlurad wrote of a supra-national administration governing

\$ Sce Ramasur, IE (1965) pp 22-26.

x Cited in Berkes, N. (1964) p. 306.

"Cited in ilsid., p. 309. 
ummab-controlled lands and including both Muslim and non-Muslim subjects. For each, their aims could be achieved through a revitalised application of Islam, with existent ideological and political structures largely intact. By 1904, however, a fourth, much more centrist, ideological current was discernible in the publication of Yusuf Akçura's essay Uद Tarz-I Siyaset (Three Forms of Politics). Born in Russia and influenced by Pan-Turkist resistance to the Czar, he argued that, with the help of the technologically superior nation-states of Europe, non-Turkish millets would inevitably attain independence regardless of the largely ineffectual creeds of Pan-Islamism and Ottomanism. The Turks should thus concentrate on reducing the provincialism and social heterogeneity of the Antolian core and improving its technological viability.

In this sense, nationalism appeared to many centrist intellectuals of the period as not only "a political solution to the survival of the state and of Turks as a cultural-political group, but also as a channel for the introduction of science and progress for the new political unit". ${ }^{28}$ The Kurdish writer Ziyz Gökalp (1876-1924) joined with Akçura in stressing that scientific thinking was crucial to the future of the Turkish people arguing that modern rationalism should be entirely separate from the influence of Islam. One, he suggested, was the private individual's relationship with God, the other the public means of administering a social collective. In 1912 he wrote that "since religion consists only of sacred institutions, beliefs and ritual, nonsacred institutions such as scientific ideas, technological tools [and] acsthetic standards... are not connected with religions". ${ }^{29}$ Influenced by Durkheim, he suggested that national consciousness was a higher stage in social crolution than the more diffuse identity of the ummab and should therefore form the basis for modernisation of the empirc.30 He went on to separate and contrast the religiosity of

2 Karpat, K (1972) p. 280.

Cied in Beskes, N. (1959) pp 271.272.

so Sce Inalcik, II. (1982) pp 356-357. Gökalp's 1916 memorandum to the Young Turk administration led to exclusion of the sphïhstam from the Cabinet, the end of the 
internationalist Islamic ideologies, with the stronger, 'cultural' spheres of social life within a nation "which have to have a uniformity and unity"." In this way, religious proto-nationalism within the Ottoman elite gradually began to take on the ideological features of European commercial statism.

For both Akçura and Gökalp, a pre-eminent element of this was literacy, the second of Mann's ideological track-layers, which he described as "the texture of morality, the substratum of culture and civilisation".32 Indeed, an important part of the Ottoman divide between the reaja and the askeri had long been maintenance of a rarefied ditan literary style within the centre. The importance of keeping official records in Islam combined with an emphasis on rhyme and allegory had, by the eighteenth century led to written state vernacular so embellished with classical Persian and Arabic vocabulary and convoluted with stylistic flourish as to be almost entirely unintelligible to the Ottoman masses. As initiation could only be achieved through a Palace or ulema controlled education and printing presses were only available to Muslims through direct petition to the Palace, this exclusiveness successfully prevented "the 'common people' from becoming interested in the laws of the realm".3 Indeed, so effective was it that the intake of Palace school students had, by the 1730s, significantly declined in quality. As a result, Ibrahim Müteferrika was licensed to print an Arabic-Turkish dietionary which was distributed at less than a tenth the price of the manuscript version. Ottoman syntax remained, however, abstruse. Within the modernising Ottoman armed forces, it was regarded as an inappropriate medium through which to draft precise orders and, as in the first of commercial-statism's media, attempts were made to standardise army manuals at the new military academies. By the mid-

whinds control of the education and judicial systems and the beginning of a state-led drive to relegate Islam to the realms of private conscience only (Mardin, S., 1981, p. $207)$.

"Cited in Ozbudun, 2. (1984) p. 36.

32 Ibid.

"Mardin, S. (1961) p. 257. 
nineteenth century centralised 'Turkification' had progressed to the extent that students were finding it easier to read European scientific texts (usually in French) than grapple with the new lexicon of locallyproduced manuals.

As such, the political efficacy of bringing the language of the state closer to that of the masses was, for Gökalp's modernist literati, a major preoccupation. His Salonika-based literary movement Genc Kalemler (Young Pens) led a campaign to eliminate "those superfluous Arabic and Persian words for which exact Turkish synonyms were current in the spoken language" and to introduce the use of European words for technical terms. ${ }^{34}$ These reforms were crucial for the transmission of Young Turk visions of nationhood and to extend shared perceptions of social identity, the third of Mann's tracklaying achievements. Such notions of 'Turkey' and the 'Turks' were first conveyed through the cultural imperialism of the West and eventually gained an ethnically-determined meaning separate from their previously derogatory associations with rural backwardness. ${ }^{35}$ In the pro-European atmosphere of Selim III's reign, Western embassies had established presses in Istanbul and distributed leaflets and bulletins on various topics. ${ }^{36}$ As these networks developed, the national and racial ideas of European writers spread through the modernist Ottoman elite. ${ }^{37}$ They informed the editorials of expatriate publications and provided a decentralised political network comparable to Mlann's sixth medium of commercial statism.

The adoption of Western styles of education, such as the first University (the Darïlfuinun established in 1900) also helped to reinforce proto-nationalist links within elite modernist circles. In a similar way to Mann's third medium of commercial statism, it not

\footnotetext{
H Ileyd, U. (1954) p. 17.

"s Sec Kushner, D. (1977) p. 20.

* Bemard Lewis notes that the French post-revolutionary diplomatic mission were, by 1802, printing bilingual propaganda for distribution in Greece, Anatoliz and the Levant (1953. pp 116.117).

"For a survey of the more prominent of these, see Lewis, B. (1953a) pp 219-223.
} 
only instilled an interest in European traditions of science and administration, but also highlighted new political models and methods of social organisation. ${ }^{38}$ Indeed, a high proportion of students at these elite academies went on to join the civil service thereby reducing the theocracy's role in educating state administrators and institutionalising the second of Mann media of commercial statism. In addition, foreign schools grew rapidly. Britain, France and the United States were, by 1914, running around 1,400 establishments containing approximately 106,000 students. ${ }^{30}$ Inspired by an evangelical blend of scientism and Christianity, many directly contributed to the growth of nationalist movements within the empire. ${ }^{40}$ Associated with this, and giving rise to similar effects, was the increase in Western-style minority schools. Within the Armenian community alone these were educating 80,000 children by 1900.11 The intertwined effects of educational expansion and a rapidly developing market economy made the non-Muslim millets religiously-determined structure increasingly inappropriate to the social needs of the nineteenth century merchant intelligentsia. ${ }^{42}$ In other words, decentralised networks of ideological power comparable to Mlann's fifth tracklaying achievement offered 'national' groups within the Ottoman empire a transcendental alternative to the state's existing social structures. Cleavages based on ethnicity and Westerninspired notions of national-statehood began to replace the millets' religiously-determined structure with secular modes of group consciousness. ${ }^{43}$ As expanding educational system increasingly recruited students from the provinces, the effects of this 'nationalisation' were soon felt within the state bureaucracy in "a continuous thread of influence in the nineteenth century from W'estern example through millet organisation to Ottoman organisation".4

* Sce Görck, F. AL. (1993) passim.

"Sec Davison, R. (1961) p. 291 and Szjliowicz, J. (1973) p. 149.

* For an account of the missionary movement in the Ottoman empire during this period, see Deringil, S. (1998, Ch. 5) and Göçek, F. ML. (1994) Pp 279-283.

"See Rodrigue, A. (1990) pp 45-46.

"See Issaui, C. (1982) passion.

"Sec Kirpat, K. (1982) passim.

+ Davison, R. (1982) p. 329. 
The 1876 Constitution and parliamentary gatherings had promised to continue a process of statc acknowledgement of peripheral economic mobility based on decentralised literary links (the fourth of Mann's media of commercial statism) with a greater devolution of political status. 15 Nevertheless, they neither produced the 'neutral' and efficient civil service called for by the modernists, nor a final end to the simoniacal despotism of the state envisaged by the growing forces of provincialism within the centre. In this sense, the Young Turk movement was born of a complex combination of peripheral petite bourgeois resentment at the continuing centripetal exclusivity of Young Ottoman modernism, fledgling Muslim capitalist class animosity towards other elements of the economic periphery (particularly the western Anatolian millets preferential and increasingly militarised relationship with the West) and bureaucratic frustration at Hamidian traditionalism and corruption. ${ }^{46}$ Forging a client base, or what Çağlar Keyder calls a "surrogate bourgeoisie", 47 out of this milieu became one of the central problems for the Young Turks in legitimising, and later (once in government) implementing, their calls for the reinstatement of the representative statutes within the 1876 constitution.

An important unifying element within Young Turk support was, as Carter Findley has shown, the economic decline around the turn of the twenticth century. ${ }^{48}$ The recovery of the Ottoman empire's export values and agricultural production following the famine of the $1870 \mathrm{~s}$ had produced only modest decreases in the cost of living while salary payments remained inadequate and irregular.97 Things gradually worsened during the 1890s as increasing instability in the imperial

is For a discussion of non-Mfuslim representation in the assemblies of the late 1870s, ece Karal, E. Z. (1982).

* Sec Görck, F. M. (1996) pp 138-141.

"See Kejder, C. (1988) pp 193-199.

"Findley, C. (1986) pp 99-103.

19 Much of the profits of this grouth passed into the hands of overseas creditors (see Donald Quataert's (1977) analysis of the effects of the German-built Anatolian railway for example). 
periphery led to poor harvests and rising crop process. ${ }^{50}$ In 1901 the Turkish press reported that officials, claiming to be on the verge of starvation, from Salonika and Istanbul had petitioned the Sultan for the settlement of their wage arrears. ${ }^{51}$ Using elite discussion centres (the seventh of Mann's commercial statist media) in these two locations, the Young Turks were able to broaden their support base within the military and bureaucracy to include disaffected workers' groups.52 Following a world-wide economic downturn in 1907, a wave of mutinies and strikes spread through Rumelia culminating in the open rebellion of the Third Army Corps units based in Salonika and Manastir. Faced with the threat of his heir-apparent being declarcd Sultan of Rumelia, Abdul Hamid agreed to the reinstatement of the 1876 constitution in July 1908. He did, however, waste "no time in planning the overthrow of the Constitution once again" by covertly funding Pan-Islamist groups opposed to the Young Turks' pro-Westernism. ${ }^{33}$ The apparent reluctance of the Young Turk Icadership to rule directly, the continuing division between federalists and unionists and the elections of November which brought 137 (out of 288) non-Turkish deputies to Parliament all fuelled fears of increasing susceptibility to European influence. ${ }^{54}$ Following the resounding success of the Committee of Union and Progress (CUP), an opposition alliance, reminiscent of the 1807 revolution, emerged in Istanbul betwieen religious students (softas), low and medium ranking ulemea and traditionalists within the capital's barracks. 55 A countercoup of April 1909 briefly allowed the federalists to take power before being suppressed by a contingent force of the Third Army including a junior officer from Salonika called Mustapha Kemal. As a

so For instance, the Greco-Turkish W'ar of 1897 and a spate of massacres in Armenia in 1896.

31 Cited in Findley, C. (1980) p. 101 (n. 58).

"See Quataert, D. (1983) Chs. 4 \& 5.

"Alderson, A. (1956) p. 71.

* In secking to explain their decision to establish a supervisory committee parallel to incumbent personnel in Istanbul rather than establish their own Cabinet, Feroz Ahmad points to their class, education, inexperience and former professions as reasons why they "did not see in themselves the capacity to rule" (1969, p. 17). See also Karpat, $R$ (1959) p. 14 (no. 31) and Tunaya, T. (1954) p. 117.

"Sec AlcCullagh, F. (1909) p. 59. 
result, Abdul Hamid was deposed in favour of Mehmed V, weakening the conservatives and providing an impetus to radical reformism.

\section{Turkish Nationalism Ascendant}

The threat to the CUP also brought the higher echelons of the military into the government. According to Feroz Ahmad, the objective of soldiers such as Mahmud Sevket (the Iraqi-born commander of the Third Army) was to keep the easily swayed rank and file troops and the highly politicised junior officers out of politics. ${ }^{36}$ While the civilians progressed with redrafting the 1876 constitution to position the Sultan and the Porte under the control of the executive and parliament, the military imposed martial law, dismissed thousands of officers promoted by Abdul Hamid and installed Sevket as Mlinister of War. ${ }^{57}$ Austria's opportunistic annexation of Bosnia-Herzegovina in 1908, the loss of Libya to Italy in 1911 and much of Rumelia to the Balkan states by 1913 solidified the pre-cminent position of the military and strongly influenced the government's unionist reform programme. ${ }^{58}$ The need for internal order and international defence, it was argued, should define the statc's 'ottomanisation' measures. As such, laws aimed at consolidating central control of the imperial periphery and supported by large increases in security expenditure were passed restricting public association, the freedom of the post-revolutionary press and the autonomy of the millets. Support for the Ottomanism of Riza and the bureaucratic modernists gradually dissipated in favour of the Turkism of Gökalp and Akçura. It also made decentralisation, promulgated by the Sabahaddin federalist faction, "seem a dangerous if not suicidal formula".59

\footnotetext{
"Ahmad, F. (1969) Ch. 3.

"Sec Kayal, H. (1997) p. 57.

so Lufrullah Kiraman writes (with considerable partisanship), "It was sharply realised, during these wars, that it was only the Turkish element of the Empire that had striven, and suffered, for the unity of the Empire" (1997, p. 8). See also Landau, J. (1981) pp 46-47 and Okyar, O. (1984) pp 46-47.

so Lewis, B. (1961) p. 200.
} 
Table Six: Parliamentary Deputies Representing Various Ottoman Communities 60

\begin{tabular}{lllllllll}
\hline Ycar & Total & Turks & Arabs & Albanians & Greeks & Armenians & Jews & Slavs \\
\hline 1908 & 288 & 147 & 60 & 27 & 26 & 14 & 4 & 10 \\
1912 & 284 & 157 & 68 & 18 & 15 & 13 & 4 & 9 \\
1914 & 259 & 144 & 84 & $\ldots \ldots$ & 13 & 14 & 4 & $\ldots$ \\
\hline
\end{tabular}

With only the Arabs and Armenians left to appease, both became, as Table Six shows, proportionally better represented in parliament as time went on. "The more backward areas of the Arab provinces received particular and immediate attention in terms of reforms" aimed at reinforcing the support of local notables through greater administrative accountability and more stringent anti-smuggling initiatives. ${ }^{61}$ Attempts were also made to settle nomadic groups through better educational provisions and land reform. Similar programmes were developed in the Armenian areas of Anatolia. Land lost during Ubaidullah's uprising was partly returned and, as Russian involvement increased during the Balkan Wars, limited autonomous powers were devolved to local agas (land-owners). ${ }^{62}$ The need to secure provincial support was also reflected in government policy towards Mluslim groups within the empire. Here the CUP was able to turn the Hamidian policy of Pan-Islamic peripheral inclusion towards developing "new cultural bonds among the whole population".63 Indeed, with all nine of the top military positions being held by nonTurkish Muslims, this was perhaps as much born of necessity as

\footnotetext{
w Source: Unpublished study by D. Rustow and F. Ahmad. Cited in Ahmad, F. (1969) p. 155.

"Kayal, H. (1997) p. 77.

Q Feroz Ahmad states that this new law "increased local autonomy in administrative and financial matters, increased and defined the powers of the govemor, and allowed for the general provincial councils to be elected by voters of the second degree, namely by local notables and landlords $(1982$, p. 423). Indeed, during a period of centralisation, this de jurn acknowledgement of peripheral power is a measure of the importance that Armenian support commanded in Istanbul.

" Karpat, K. (196+2) p. 269.
} 
design. ${ }^{\text {at }}$ To this end, efforts to incorporate elements of the Muslim mercantile classes were reinforced within the elite schools of the centrc. As Joseph Szyliowicz notes in his study of the Mektabi Mülkiye,

"during the Young Turk era, a marked shift took place in recruitment patterns - occupationally towards persons from official backgrounds, geographically away from Istanbul - so that the great majority of the students were sons of officials located in provincial and district centres. Furthermore... a second group, students of ayan-esraf background, was also well represented at the school".".5

However, both the changes in provincial political representation and the programme of reforms initiated by CUP also contained an increasingly prominent element of Turkish ethnocentrism. Article 17 of the 1909 constitution stipulated that Turkish language classes were to be a compulsory part of the curriculum and that for secondary and higher levels Turkish was also to be the medium of instruction, thereby making uniform previous Hamidian policies. An entirely new measure, and one that met considerable resistance (particularly within the Arab provinces) was the requirement to use Turkish, rather than the Arabic of classical jurisprudence, in the judicial system. Furthermore, in the absence of accurate records, the government was often accused of equating linguistic divides with ethnicity and thereby inflating the size of the empire's 'Turkish' citizenry, and thus its parliamentary majority, ${ }^{60}$ by including large numbers of peripheral Turcophones. ${ }^{67}$ The problem was worsened by the stipulation that voters must be registered tax-payers which tended to exclude Arab and Kurdish nomadic groups. ${ }^{68}$ In all, the changes brought about by the CUP can be seen as part of a gradual move from reform aimed at Ottomanist integration (the strengthening of ties to a multinational

4 According to Ilasan Kayalh, two were occupied by Arabs (Mahmud Şevket and his replacement at the Third Army command, Hadi Pasha), two by Albanians, two by Circassians and one by a Tartar, a Bosnian and a Georgian (1997, p. 88).

us Szyliowicz. J. (1971) p. 397.

*s One deputy stood for every 50,000 Ottoman citizens (Kayal, H., 1997, p. 85).

"Sec Karpat, K. (1985) pp 164-168.

a For instance Syed Ali Edroos notes that only one deputy was returned from the province of Jordan $(1980$, p. 8$)$. 
state pursued by Abdul Hamid) to Turkist assimilation (ensuring group association with the national identity of the centre). .99 Indeed, as Hasan Kayali's study of Arab resistance shows, the image of Turkish chauvinism became an effective means of resisting state centralisation for peripheral notables. ${ }^{70}$

While the strongly centrist ideological flavour of the CUP's attempts to build political links with the empire's periphery largely consigned them to failure, economic reforms had arguably more success. Many, such as the drafting of new commercial codes and the spate of concessions to foreign firms to extend the rail, highway and telegraph networks ${ }^{71}$ did help to stimulate manufacturing and agricultural productivity. ${ }^{72}$ In all, though, public spending on such infra-structural projects was severely curtailed by security and armament budgets. The Ministry of Public Works, for instance received only 3.3 per cent of fiscal allocations for the year 1911-1912 compared with 30.7 per cent directed to the Ministry of War, 4.7 per cent to the navy and 3.9 per cent to the gendarmerie. ${ }^{73}$ To pay for these, borrowing from the Public Debt Administration increased, exceeding debt servicing for the first time since 1881.74 Extraction was also stepped up (particularly in the agricultural sector) enlarging the state's total taxation revenue from 148 million liras in 1909 to almost 185 million in $1910 .{ }^{75}$ Nevertheless, estimated expenditure still exceeded expected receipts by more than 20 per cent, rising to over 25 per cent by 1912 (the actual deficit was generally much higher). ${ }^{76}$

\footnotetext{
${ }^{69}$ See Eriksen, K. et al (1991) pp 392-395.

${ }^{70}$ Further public opposition arose from the provincial appointment of officials who sought to impose unionist principles of secularism and individualism. See Kayal, $H$. (1997) pp 94-95.

71 See Mears, E. (1924) pp 218-233.

72 See Ahmad, F. (1980) pp 335-336.

${ }^{73}$ See Cumberland, W. (1924) p. 399.

${ }^{74}$ Çağlar Keyder calculates (after Yahya Tezel) that from 1908-1914 60 million liras were borrowed and 43 million liras repaid (1980) pp 325-326.

75 This was despite the abolition of military exemption duties under legislation in 1908 designed to end the millet system which cost the treasury over 6 million liras in lost revenue (Ahmad, F. 1969 p. 70).

76 See Emin, A. (1930) p. 94.
} 
With the outbreak of war with the Entente in 1914, the CUP set about attempting to create a national economy through a series of budgetary reforms. The Capitulations system was abrogated in September 1914 ending the tax-exempt status of foreign passportholders which, following the revocation of the Anglo-French banking monopoly, allowed the state "for the first time in its history... to practise a monetary policy". 77 The treasury printed 159 million liras against gold held in Germany giving the state the equivalent of an interest-free loan which was soon protected by higher excise duties on imports. New taxes were imposed on luxury goods (those not requisitioned for military use), war earnings and male non-combatants of military service age. Duty payable on gross production was increased to 12 per cent coupled with a further, and highly unpopular, 12 per cent surplus acquisition at state-stipulated rates of remuneration. ${ }^{78}$ To improve collection efficiency and commercial cohesion, legislation was passed in April 1916 unifying Ottoman coinage which had, until then, more than eighty different valuations. In all, as Feroz Ahmad notes the state "began to play a more direct and open role in the economy" not least by embarking upon a policy of "fostering an entrepreneurial class among the Turks". ${ }^{79}$

This led to a period of high domestic growth and an increase from 3 per cent in 1908 to 38 per cent in 1918 in Ottoman capital's share of corporate investment. ${ }^{80}$ With the establishment of a war-time oneparty system led by the triumvirate of Enver, Jemal and Talat Pashas, parliamentary lobbying from competing interest-groups was largely replaced by a clientelistic system of mercantile cadres. These were brought together under co-operatives schemes to establish trading and finance companies with a 'national' orientation, eventually leading to the partial displacement of non-Turkish merchant groups and

\footnotetext{
${ }^{77}$ Keyder, Ç. (1980) p. 326.

${ }^{78}$ See Emin, A. (1930) Ch. 8.

79 Ahmad, F. (1980) p. 337 \& 341 . In some ways this was an attempt to return to the militarised economy of imperial expansion. Indeed, Ahmad writes elsewhere that, "this emphasis on etatisme was merely a reflection of the traditional role of the state in the Ottoman Empire and in Islamic societies generally" (1969, p. 157).
} 
closer bureaucratic control of the economy. ${ }^{81}$ In a policy described by Ahmed Emin as 'economic Turkism', new laws were passed decreeing that every factory whose workforce was (apart from technical experts) entirely Turkish would be exempt from taxation and export excise for fifteen years and would receive free tools and materials not locally available. These measures were reinforced a year later, in 1916, with legislation obliging all companies possessing such concessions to carry out all their business exclusively in Turkish. ${ }^{82}$ New investment was also allocated to artisan training centres and vocational courses for both men and women with the more able students often seconded to German institutions and corporations. "The idea", Emin concludes, "was to conquer fields of activity monopolised by nonTurks". ${ }^{83}$ While this largely failed to arrest the war-time decline in industrial and agricultural production, it did succeed in promoting an ideological change among the emerging Turkish bourgeoisie - "the mentality that despised trade and industry and believed that government and military occupations are most worthy of an Ottoman Turk" was, partly at least, overcome. ${ }^{84}$

Concurrent with the rise in corporatism was the declining political role of the ulema. While the state initially attempted a call-to-arms with a declaration of jibad in 1914, once it became apparent that this could neither ensure adequate recruitment nor the loyalty of non-Turkish Muslims, a policy of restricting Islamist opposition was preferred. Influenced by Gökalp's call for the separation of state and religion, reforms were enacted in 1916 which removed the seybuilislam from the cabinet and ended his administration of the empire's charitable assets as well as transferring the shariab courts to the Ministry of Justice and the clerical schools to the Ministry of Education. As a result, there emerged a new class of professional teachers in direct competition

\footnotetext{
${ }^{80}$ Keyder, Ç. (1980) p. 326

81 Turkish ascendancy was eventually assured by the mass expulsion of Armenians in 1915 and population exchanges with Greece following the war. See Keyder, Ç. (1988) pp 198-199.

${ }^{82}$ See Emin, A. (1930) pp 114-117.

${ }^{83}$ Ibid. p. 115.
} 
with the clerics of the old educational order. Many, such as İsmail Hakks, a lecturer (and later rector) at the Darilffinun, saw their role as "freeing the individual from the constraints of the clericals, religious orders, homes, streets, coffee houses, graveyards and beggars". 85 During the war, many departments recruited staff from overseas (predominantly Germany) leading Hakk to comment that it had become "an experimental ground for all kinds of convictions, methods and traditions". 86 Other professional groups were also increasing their power during this period. The elite medical schools, long a channel of Western methods (as well as the birthplace of the CUP), had given rise to a class of practitioners embedded in extensive and essentially secular discursive literary networks. The expansion of state influence in the judiciary since the Tanzimat had a similarly secularising effect on the white-collar classes. Professional lawyers, trained in Western precedents, began to encroach on the traditionally ecclesiastical domain of civil law institutionalising the fifth of Mann's media of commercial statism. In 1917, a new family code was introduced which positioned the legality of marriage and divorce within the authority of the state and away from the shariab courts By the time of the 1918 Mudros armistice "religion was", as Niyazi Berkes puts it, "divested of its temporal influence in state, educational, legislational, judicial, and financial affairs". ${ }^{87}$

The effects of these changes reinforced the divide between traditionalist and modernist within the centre. They also strengthened the links between anti-modernist groups within the state and elements of the peripheral elite disadvantaged by the war-time rise in centralism and Westernism. ${ }^{88}$ Following the fall of the CUP government in 1918 and the subsequent Allied occupation of the major Mediterranean cities, this loose alliance became of key importance in securing the Anatolian heartland. With the Arabs and Armenians courting the

${ }^{84}$ Consul General G. Bie Ravndal writing in 1912. Cited in Ahmad, F. (1980) p. 337. 85 Writing in 1914. Cited in Berkes, N. (1964 [1998 edition] p. 403.

${ }^{86}$ Writing in 1919. Cited in Oncü, A. (1993) p. 153.

${ }^{87}$ Berkes, N. (1964 [1998 edition]) p. 416. 
Entente in preparation for the peace talks in Paris, gaining the endorsement of the Kurdish minority was crucial for Damad Ferid Pasha's cabinet appointed by the Great Powers in March 1919. The position of the Kurdish leaders was, however, ambivalent. Many, such as the cleric Sheikh Abdul Qadyr (the second son of Ubaidullah), had long resented Young Turk centrism and called for the establishment of autonomous Kurdish provinces. ${ }^{89}$ Others went further and joined with the Armenians to press for "a united and independent Armenia and an independent Kurdistan, with the assistance of a Great Power". ${ }^{0}$ Nevertheless, following the Greek invasion at Izmir and Italian landings at Antalya in May 1919,91 it was the traditionalists' links with the centre and long-standing opposition to Western cultural encroachment that seemed likely to be most efficacious to those resolved to resist militarily further territorial losses.

To Mustafa Kemal, already experienced in tribal diplomacy from his war-time appointment in Aleppo, the ideological relationship between Muslim peasant and Islamic state, traditionally conceived, was to be the basis for "co-opting Kurdish tribal leaders into the resistance movement and in mobilising Kurdish loyalty to the Caliph-Sultan and the country".92 From its inaugural conference in Erzerum in July 1919, Kemal's Society for the Defence of the Rights of Eastern Anatolia argued that "all Islamic elements (i.e. ethnic communities) living in this area are true brothers... of the same religion and race as ourselves whom it is impossible to divide".93 The importance of Islamic legitimisation within the movement can be seen in the

${ }^{88}$ See Cizre-Sakallığlu, Ü. (1995) p. 759.

89 According to Andrew Mango, Abdul Qadyr's movement was successful in securing the endorsement of the predominantly Sunni Kurdish guilds of Istanbul and federalist statesmen such as Fuad Pasha, but was restricted in its capacity to mobilise the disparate Kurdish heterodoxy beyond the province of Diyarbakur (1999, p. 5).

${ }^{0}$ Namely England. Şarif Pasha cited in McDowall, D. (1992) p. 131. This proved unpopular with many in Kurdistan (especially those who had engaged in the Armenian massacres and deportations of 1915).

91 The 1916 Sykes-Picot arrangements to divide Anatolia between Britain, France and Russia had been revealed by the Bolsheviks a year earlier and was still a cause of widespread alarm.

${ }^{92}$ Kirişci, K. \& Winrow, G. M. (1997) pp. 84-85. 
background of the delegates to the conference. Out of fifty-six, twenty-one were connected to the ulema.94 Similarly with the establishment of the Grand National Assembly in Ankara in April 1920 , more than one-fifth of the deputies were clerics and many others, as Table Seven suggests, were Kurdish tribal leaders. ${ }^{95}$ In many ways, this demonstrates the limited progress of commercialstatism outside the western Anatolian alliance of urban professionals and merchant elites. For not only did the ulema provide immanent morale in the form of fatwas endorsing the assembly (152 sheikhs from numerous provincial towns supported Ankara's edict calling on all Muslims to liberate the Caliph imprisoned in Istanbul), they also worked with local notables in collecting the 40 per cent income tax levied on all households. ${ }^{96}$ So with domestic revenues in place, local mobilisation reaffirmed by the Carthaginian peace at Sèvres and gold and weapons arriving from the Politburo, Kemal not only offered to protect these sheikhs and ağas, but, as Martin Van Bruinessen notes, he also "had power that he might delegate to them, whereas the [Kurdish] nationalist organisations did not". ${ }^{97}$ Thus the War of Independence was launched in Kurdistan using Kurdish troops commanded by Turkish officers under the banner of Islam. ${ }^{98}$

In the tradition of Mahmud Şevket, Kemal believed that it was imperative to keep both the soldiery and the field officers out of politics. As before though, this proscription did not extend as far as senior staff commanders. Although Kemal himself resigned his commission (until September 1921 when he was appointed Commander-in-Chief), most of the other positions of power were

${ }^{93}$ Opening proclamation cited in Mango, A. (1999) p. 8.

94 See Toprak, B. (1981) p. 64.

${ }^{95}$ See Rustow, D. (1957) p. 73 and Mango, A. (1999) p. 12. It is worth noting that the assembly also included ninety members of the Istanbul parliament (see Rustow, D., 1981, p. 66).

${ }^{96}$ See Toprak, B. (1981) p. 65.

97 Van Bruinessen, M. (1992) p. 279. My parenthesis. See also Webster, D. (1939) pp 87-88 and Gökay, B. (1996) p. 67.

${ }^{98}$ See Bulloch, J. \& Morris, H. (1993) p. 89 and McDowall, D. (1996) p. 15. 
filled by serving members of the armed forces. ${ }^{99}$ This reliance on military personnel networks was unsurprising. As Dankwart Rustow has noted, "seven years of almost uninterrupted hostilities (with Italy, 1911-12; in the Balkans, 1912-13; and in the First World War) brought the Ottoman Empire closer to being a garrison state than it had perhaps been at any time since its infancy". 100 In such a militarised environment, it was only logical for soldiers to take on an extended role in administration. Indeed, crucial to the nascent government in Ankara were the seven imperial army corps, which, with the Allies encamped along the western seaboard, were concentrated in Anatolia. Although severely depleted, they retained a clear chain of command and, vitally, control over the telegraph infrastructure. ${ }^{101}$ The corps commanders also provided a useful link to demobilised officers in Istanbul. Many of these were affiliated to the commercial statist ideology of the centre and thus saw Kemal's efforts as merely a continuation of Enver's policy of militarily reinforcing populist movements in the south-east in preparation for the armistice. $^{102}$

The War of Independence solidified Kemalist forces, restrained irregular army units and incorporated other resistance movements in Western Anatolia and Thrace. ${ }^{103}$ Within the new order of the Turkish nation-state, Kemal envisaged the military moving from its position as the de facto "expression of Ottoman society" to the de jure "fountainhead of progressive practices". ${ }^{104}$ In this sense, the rulers of the Ankara movement were not an instrument of the 'reactionary coalition' of old regime notables and emergent capitalists described by

99 The Chief-of-Staff, Fevzi Çakmak, for instance, was promoted to a full Cabinet member eventually serving as Prime Minister from January 1921 to July 1922 (see Harris, G., 1965, pp 54-55).

100 Rustow, D. (1959) p. 518 . His parenthesis.

${ }^{101}$ See ibid. p. 519. Elsewhere Rustow reports that the telegraph system was particularly important in maintaining Kemal's links with Istanbul. In three days in 1920, 217 telegrams were sent to the House of Representatives alone (1968, p. 270). $102 \mathrm{Kemal}$, too, saw the value of utilising former-CUP expertise. See Zürcher, E. (1984) p. 160.

${ }^{103}$ See Smith, E. (1959) pp 67-68.

104 Turfan, N. (1987) p. 4 and Harris, G. (1965) p. 55. 
Barrington Moore. ${ }^{105}$ Rather, as Ergun Özbudun argues, their alliance was born of the "exigencies of the War of Independence" itself. 106 With no Ottoman tradition of aristocratic control over the means of production, the limited extensiveness of commercial statism and with the nascent Turkish bourgeoisie fractured by territorial partition, the military was both able to claim territorial legitimacy and to formulate the basis for a future bureaucratic order. ${ }^{107}$ Nonetheless, once the war was over and the geo-political position of Turkey re-negotiated at Lausanne, the resistance movement began to dissipate and a tension emerged between Ankara's provincial supporters and the military's position as final arbiters of constitutional interpretation. ${ }^{108}$

Table Seven: Birthplaces of Military and Civilian Leaders, 19181923. ${ }^{109}$

\begin{tabular}{lcccccc}
\hline & $\begin{array}{c}\text { Total } \\
\text { known }\end{array}$ & $\begin{array}{c}\text { Rumelia } \\
\text { \& Cyprus } \\
\%\end{array}$ & $\begin{array}{c}\text { Istanbul } \\
\%\end{array}$ & $\begin{array}{c}\text { Anatolia } \\
\%\end{array}$ & $\begin{array}{c}\text { Arab } \\
\text { Provinces } \\
\%\end{array}$ & $\begin{array}{c}\text { Caucasus } \\
\%\end{array}$ \\
\hline Istanbul Civilian Ministers, 1918-22 & 40 & 20 & 48 & 23 & 5 & 5 \\
Istanbul Military Ministers, 1918-22 & 26 & 8 & 46 & 23 & 8 & 15 \\
Ankara Civilian Ministers, 1920-23 & 23 & 13 & 9 & 78 & 0 & 0 \\
Ankara Military Ministers, 1920-23 & 9 & 33 & 56 & 11 & 0 & 0 \\
Nationalist Commanders, 1919-22 & 25 & 24 & 44 & 32 & 0 & 0 \\
\hline
\end{tabular}

Although preceded by a somewhat similar blend of representational modernism and military etatism in the CUP administration, Kemal's incremental inkalab had not proceeded unopposed. Within the Ankara assembly, resistance became centred around a heterogeneous minority (referred to as the 'second group') of broadly Islamists and peripheral elites. ${ }^{110}$ During the War of Independence they had formulated plans to attach the gendarmerie to the Ministry of Interior (i.e. under civilian control) seeing the assembly as operative only until the Sultan

${ }^{105}$ Moore, B. (1967) Ch. 8.

106 Özbudun, E. (1981) p. 86.

${ }^{107}$ See Trimberger, E. K. (1978) pp 41-43.

${ }^{108}$ See Harris, G. (1965) p. 55. For a discussion of the constitution adopted between 1921 and 1923 see Altuğ, Y. (1984) pp 131-134.

${ }^{109}$ Source: Abbreviated from Rustow, D. (1959) p. 527. 'Military' is taken to be all active and retired military personnel except for those who pursued a civilian career after leaving. 
had been liberated. With success on the battleground imminent, Kemal moved against the dissenters. Fatwas were sponsored questioning the historical legitimacy of an unelected and hereditary leadership and Abdul Mecid was appointed in 1922 as a purely spiritual Caliph with neither the title nor the political influence of a Sultan. ${ }^{111}$ To reduce traditionalist influence still further, the officer corps was purged and loyalists were appointed to the leadership of a nation-wide 'Peoples Party' (Halk Firkasi) ${ }^{112}$ which, with the extension of the Treason Laws to include pro-Sultanate agitation, gave ex-members of the military an institutionalised political role. So much so that in the elections of June 1923 only three members of the 'second group' were returned to the assembly. Indeed, it is indicative of the enduring importance of the military to Kemal's vision of social reform that he only felt secure enough to announce the abolition of the Caliphate in March 1924 after insisting upon a pay-rise for the entire armed forces against the wishes of the civilian members of his Cabinet. ${ }^{113}$

As Mesut Yeğen observes, "the Caliphate was an institution which guaranteed that the bond between the Ottoman political centre and the Muslim elements of the 'periphery' was to be a loose one". ${ }^{114}$ Its abolition threatened both the ideological legitimacy and the relative autonomy of peripheral, particularly Kurdish, traditionalists and notables unaffected by the commercial statism of the centre. This factor, coupled with a pronounced decline in provincial representation in the Ankara assembly and the proscription of the Kurdish language within the education and judicial systems,

${ }^{110}$ See Edib, H. (1928) p. 183.

${ }^{111}$ See Deringil, S. (1993a) p. 173 \& İnalc1k, H. (1982) pp 353-356.

112 This quickly came to replace the Society for the Defence of the Rights of Eastem Anatolia (see Yerasimos, S., 1987, p. 78).

${ }^{113}$ See Harris, G. (1965) pp 56-57. Also instrumental in Kemal's timing was, of course, the successful re-negotiation of Sèvres at Lausanne in July 1923. For an analysis of the Turkish delegation to Lausanne, see Davison, R. (1963a) pp 199-209. 114 Yeğen, M. (1987) p. 221. 
precipitated numerous peripheral rebellions. ${ }^{115}$ It also added to the support of a break-away political party, the Progressive Republican Party (Terakkiperver Cumburiyet Firkasi), which emerged in November 1924 advocating less interventionist policies. ${ }^{116}$ In south-east Anatolia, the pacification of Sheikh Said's large-scale rebellion amid immense bloodshed the following year (up to 250,000 people were killed) provided Kemal with the emergency conditions in which to suppress not only "all public vestiges of separate Kurdish identity", but also all organised resistance within the assembly. ${ }^{117}$ The Law for the Maintenance of Order and an amendment to the treason laws to include "the exploitation of religion towards political ends" imposed a system of political monism so severe that most newspapers disappeared, no parliamentary opposition emerged for twenty years and an overtly socialist organisation was impossible until the 1960s. ${ }^{118}$ In other words, with little progress in the extensiveness of collective perceptions of 'national' identity. Kemal's government was able to continue the militarist autonomy of the war-time regime.

Table Eight: A selection of reforms 1922-1935'119

1. The abolition of the sultanate in 1922 followed by the establishment of the Turkish republic in 1923.

2. The abolition of the Caliphate in 1924.

3. The abolition of the seybilislam in 1924.

4. The abolition of the Ministry of Religious Affairs in 1924.

5. The abolition of the shariab courts in 1924 .

6. The abolition of the medresse schools in 1924.

7. The prohibition of tariqas (religious brotherhoods) in 1925.

8. The prohibition of the fez in 1925.

9. The adoption of the Gregorian calendar in 1925.

10. The adoption of the Swiss code of civil law in 1926.

115 See Frey, F. (1978) p. 59. David McDowall notes that within a year only 215 out of the 4,875 functioning schools in Turkey were located in Kurdish speaking provinces (1992, p. 192).

${ }^{116}$ See Yerasimos, S. (1987) pp 82-83

117 Under what Ahmed Emin describes as a "pretext", the Progressive Republican Party was accused of providing a rallying-point for the rebels and dissolved (1947, p. 48). See also McDowall, D. (1993) p. 37 and (1996) p. 15.

${ }^{118}$ See Yerasimos, S. (1987) pp 83-84.

${ }^{119}$ Source: Toprak, B. (1987) p. 223. 
11. The adoption of European numerals in 1928.

12. The adoption of Latin script in 1928.

13. The deletion of Article II of the 1924 constitution stipulating Islam to be the state religion.

14. The enfranchisement of women for municipal elections in 1930 and national elections in 1934.

15. The initiation of a programme removing Arabic and Persian words from the Turkish language in 1931.

16. The adoption of the metric system in 1931.

17. The adoption of family surnames in 1934.

18. The change of weekly holidays from Friday to Sunday in 1935.

However, for such coercive longevity, an exclusive reliance on military support was impracticable. Kemal's programme of reforms (some of which are listed in Table Eight) required a civil bureaucracy that was both loyal and modern. Once prohibited from holding elected office after 1924 (a measure which usefully prevented the traditionally highly politicised junior officer corps from extending their influence) reliable ex-officers were used as a recruitment base to imbue the civil bureaucratic class with the values of the new order. ${ }^{120}$ Kemal also selected "a small group of highly motivated administrators who became leaders in the Grand National Assembly and in the cabinet" from modernist elements of existing bureaucracy. ${ }^{121}$ Legitimised through a widely-publicised fear of revolutionary socialism and a determined campaign to portray Islamic traditionalism as retrogressive and obscurantist, this oligarchic cadre drafted a programme of legislation designed to extend mass compliance beyond the war-time appeal of Kemal's charismatic leadership. The adoption of the metric system, the Swiss legal code and the Gregorian calendar all provided the state's administrators with standardised tools to which both local variation and clerical influence were marginal. ${ }^{122}$ Similarly, in an extension of the ideas of Ziya Gökalp and a scheme

${ }^{120}$ See Rustow, D. (1959) pp 550-551 as well as Tachau, F. \& Heper, M. (1983) pp 19-20. It should also be noted that as part of the same process the Chief-of-Staff was placed under the direct control of the President thereby isolating the position from civil control.

121 Bent, F. (1970) p. 57.

122 See Turan, I. (1984) pp 106-108 \& Stirling, P. (1958) p. 397. 
devised by Enver Pasha during the war, the Latin script was taken up in place of the Ottoman alphabetical blend of Arabic and Persian. ${ }^{123}$

These measures did little, however, to bridge the divide between the Turkish centre and the periphery. In the case of linguistic reform, the plethora of invented neologisms further widened "the gulf between the official and literary language and the language of the common people". ${ }^{124}$ Moreover, the bureaucratic state's emphasis on progress in science and economics ${ }^{125}$ proved an inappropriate medium through which to extend a state-wide infra-structure of mass communication, with the consequence that participation, both political and ideological, in the Westernising reforms remained minimal. Although attempts were made to better the conditions of the peasantry by reducing taxation, war damage (the productive capacity of the country was down 20 per cent on pre-war levels) and an acute labour shortage meant that substantive land reform was impossible. ${ }^{126}$ With the traditional relationship between peripheral notable and small-holder untouched, the state bureaucracy also found it difficult to extend mass education. The number of primary schools only rose from 5,172 in 1923 to 6,043 in 1931 with the south-east remaining largely illiterate (particularly in Turkish). ${ }^{127}$ "Rather than reevaluate these policies", İlter Turan concludes, "the bureaucrats were inclined to impose them by compulsory means, confirmed in their apprehensions that the largely peasant masses... should not be provided with opportunities to participate in the political decision-making process".128

A more favourable client base was to be found within the industrial and technological sectors of the economy. Here, Kemal extended the

123 See Tachau, F. (1964) pp 193-194.

124 Lewis, G. (1984) p. 210.

125 See Lemer, D. \& Robinson, R. (1960) p. 21.

${ }^{126}$ See Ahmad, F. (1981) pp 153-154.

${ }^{127}$ Amalgamated from Winter, M. (1984) p. 192 and Yerasimos, S. (1987) p. 86.

${ }^{128}$ Turan , I. (1984) p. 111. The Village Law of March 1924, for instance, sought to give the Anatolian peasantry representation mechanisms by making the vilayet a legal 
CUP's policy of tax concessions and the assistance of private accumulation mechanisms, leading to some success in improving economic output. ${ }^{129}$ As before, however, the Turkish bourgeoisie proved difficult to generate from above and the result was the further institutionalisation of the pre-war entrepreneurial cadre "via the enrichment of particular individuals through state resources and support".130 In all, these policies, coupled with the continuing ideological pre-eminence of a loyally secular intelligentsia, led to a narrow, state-stipulated definition of 'modernisation', a highly monist view of citizenship and an intensive brand of nationalism largely restricted to the urban professionals and large-estate farmers of western Anatolia. As a result, the Kemalist revolution remained a predominantly intra-elite phenomenon with little social restructuring taking place outside the centre and without the levelling of social stratification and reduction in provincialism associated with Western nationalism. In other words, it failed to attain ideological power's fourth tracklaying achievement and bring the masses closer to the state.

\section{Conclusion}

In many ways, the conclusion of the Turkish revolution represents the failure to resolve the social contradictions inherited from the Ottoman empire. As outlined at the beginning of this chapter, power contention at the end of the nineteenth century predominantly revolved around the imperial tradition of hierarchical centralisation. Peripheral forces represented first by the Young Turks and then, for the initial period of liberation only, by the Kemalists, challenged the institutionalised position of the Ottoman elite. Ultimately, though, the process proved retrogressive as the empire's ideological emphasis on

and administrative entity, but produced negligible effects on social and economic conditions (see Kolars, J., 1973, p. 187).

129 See Hershlag, Z. (1984) pp 175-176. William Hale records that GDP rose from 640 million liras in 1923 to 1207.1 million in $1930(1984$, p. 163). For an alternative view, see Robinson, R. (1963) p. 115. 
universalism, cosmopolitanism and normative civilisation was replaced, at least in terms of state policy, by particularism, enforced uniformity and militarism thereby reversing the 'tracklaying' achievement of the Caliph/ummab order. Essential elements of this retrogression were networks of discursive literacy which, decentralised by the emerging professional classes, were instrumental in both bringing the provinces to power and, once re-centralised by the Kemalist bureaucracy's censors, restoring a redefined state elite. ${ }^{131}$ Ultimately, though, such a top-down approach could not be successful in deploying ideological power's third tracklaying potential and extend social identities into the territorial periphery.

Nevertheless, religion, as Şerif Mardin notes, continued to serve a "double function: for the rulers, that of linkage with the lower classes, for the ruled, that of an alternative to the polity and a buffer against officialdom". ${ }^{132}$ This dialectic persisted throughout the ideological reordering that took place during the 1920s. Contrary to Ziya Gökalp's vision, Kemalism did not entail a separation of state and religion. ${ }^{133}$ Instead, the republican state assumed "the jurisdiction to exercise almost unlimited control over all the religious matters in the country". ${ }^{134}$ Through the Directorate of Religious Affairs, created in 1924, a monist vision of national unity was legitimised and built into the constitution informing both policy-making and bureaucratic implementation. ${ }^{135}$ Non-statist groups within the periphery were also aware of the need to develop ideological power networks in order to ensure organisational immanence. Beyond this bifurcation, however, religion retained its capacity to transcend cleavages institutionalised by non-ideological power sources and perpetuated its grip on interpersonal ethics and familial relations. In the other words, the

${ }^{130}$ Boratav, K. (1981) p. 170.

131 Later, from 1929 onwards, all printing had to be produced using the newlyadopted Latin script thereby excluding all but the thoroughly 'modernised' from these discursive literary networks. See Webster, D. (1939a) pp 254-255.

132 Mardin, S. (1971) p. 204.

133 See Keddie, N. (1997) p. 32.

${ }^{134}$ Dumont, P. (1987) p. 2. 
commercial statism of the centre could not access the sixth of ideological power's tracklaying achievements and was largely excluded from familial relations and, what Mann describes as, the 'core social spheres'.

Indeed, unlike the case of the Christian ecumene, the growth of science and rationality, the first of Mann's secularising forces, did not present an inherent threat to this social role. The influential work of Abduh and al-Afghani, as well as their protégés in the Young Turk movement, espoused views that had long been part of accepted debate within mainstream Islamic thought. What could be considered 'secularism' (although such a term would have been unthinkable even for the most ardent modernist of the period) emerged within this ideological channel not as a result of rational endeavour per se, but through the international transmission of the European triumph of reason over faith. For thinkers such as Akçura and Gökalp, national progress, defined in terms of Western models, was incommensurate with a state-organised faith that was, itself, intrinsically supra-national. While not averse to the use of Islamic symbolism and jurisprudence in defence of their cause (a fact reflected in the blurred distinction between factions within the Young Turk movement), religion, they argued, should be relegated to matters of private conscience and not impinge upon the public administration of popular sovereignty. So whereas processes of secularisation in Europe, according to Mann at least, were born of the challenge that rational science represented to the Church's cosmological authority, in Turkey non-religious modes of social explication emerged through the organisation of ideological alternatives to Caliph's political power.

With only a small coterie of western Anatolia elites for a client base, however, the ideology of a centrist urban intelligentsia was unlikely to gain extensive institutionalised credence. While middle-class

135 For an account of Kemal's attempts to 'Turkify' Islamic ritual, see Reed, H. (1980a) pp 325-326. 
expansion was sufficient to meet the recruitment demands of an expanding state bureaucracy, it did not provide the constitutionally required mass political participation and was thus unable to 'nationalise' the state. ${ }^{136}$ Instead, the Kemalist state continued the particularism embodied in the CUP's 'economic Turkism' in a perpetual struggle to extend its support base. ${ }^{137}$ Without an extensive bourgeois citizenry defining themselves as 'the nation' to which the state ought to be coterminous, the Kemalist administration remained highly autonomous. It was able to continue the militarisation of commercial statist proto-nationalism first begun in the build-up to the First World War almost unilaterally. Severely weakened by territorial division and the devastation of the First World War, Turkish civil society could exert little influence over the direction of social reform. As a result, it was the state itself, rather than what Mann terms 'emergent capitalism', that formed the primary basis for the diffusion of notions of popular sovereignty.

That is not to say, however, that mercantile exchange was insignificant in the organisation of ideological alternatives to the Ottoman regime. The third of Mann's secularising forces, navigational advances, brought increasing numbers of foreign merchants to the western seaboard. Institutionalised by the Capitulations system, they increased peripheral economic mobility and brought with them the culture and technology of the Enlightenment. It was through this ideological channel that ideas of national statehood, the fourth of Mann's secularising forces, became influential following the French Revolution. Non-Turkish millets were able to exploit their cultural autonomy within the Ottoman polity to intensify religious and political networks of interaction with external powers such as the

\footnotetext{
${ }^{136}$ See Heper, M. (1976a) pp 485-486. This explains why, in Frederick Frey's words, "The Kemalists concentrated on the extension and the consolidation of the modernist beachhead within the ruling elite" (1963, p. 313).

137 Given that, in Metin Heper's words, "the State elites took democracy not as the representation and reconciliation of the interests and opinions of different social groups but as finding the one best policy by the enlightened elite, that is, by the State elites themselves" (1991, pp 48-49, his emphases), this did not imply a loss of topdown control (see Turan, İ., 1984a, p. 89).
} 
Orthodox Church and British Whigs. The conflict between their restrained status, political awareness and economic mobility found expression through both separatist agitation and, for those recruited by the expanding state bureaucracy of the nineteenth century, reformism from within the centre. Such state creating nationalism informed Turkish national consciousness and prompted efforts aimed at reinforing the state (defined as both the empire and the Turkish 'nation') from the CUP.

The Ottoman state had, however, spent centuries institutionalising peripheral diversity and a highly structured centre/periphery (askeri/reaya) divide. Although greatly challenged during the nineteenth century, its networks of ideological organisation (which had provided both the flexibility and omnipresence fundamental to the empire's longevity) could not easily be redirected. The ulema, like the European ecumene described by Mann, had been one of the primary vehicles for institutionalising the relationship between ruler and ruled and thus an important element in legitimising and transmitting the ideology of the centre. Without the exegetic autonomy of the Church and the polarising effects of its sixteenth century schism, however, the Ottoman theocracy was less suited to what Mann terms the 'religious proto-nationalism'. Both in ideological and political terms the ulema's universalist foundation and intermediary role between Caliph and subject (including the nonMulsim millets as 'people of the book') were strongly multi-national and therefore intrinsically inappropriate to the needs of the Turkists. Particularly out of step with the modernising centre's view of the twentieth century was their emphasis on the scholarly value of Arabic and Persian. Unlike in Europe, classic scriptures could not be approached in the mother-tongue of the student so Ottoman vernaculars remained localised within the 'cultural traditions' of the region. The break-down in the relationship between clergy and state during the nineteenth century (described in the previous chapter) led 
to a decline in educational provision further fragmenting religious discursive literary networks. ${ }^{138}$

So rather than expanding from the extensiveness of theocratic networks of discursive literacy and education, commercial-statism was largely imported from the West and institutionalised in parallel to what may be called 'traditional' ideological structures. Linguistic standardisation, first implemented by the military, was an innovation unconnected to the ulema's ideological networks and one that spread not from the existent medresse education system, but originated in the Western-orientated and increasingly German-staffed military academies. Similarly, educational reforms and the bureaucratisation of the kalemiyye which led to a significant growth in non-clerical state administrators, were based on European models of the rational state imposed by Istanbul and unsupported by organic changes in civil society. So, despite gradually involving more social groups from the periphery, modernism's 'secularising' effects were restricted to an intelligentsia born of the centrist adab training systems. Incorporated into this etatist elite through attempts by the state to nurture a 'national' bourgeoisie were commercially mobile social networks from western Anatolia and a predominantly Turkish cadre of professional lawyers and educators.

Institutionalised as a result of Western-inspired modernism, these social networks lacked extensive literary links to the mass of civil society which remained largely embedded in the ideological organisation of the ulema. With the failure of the modernisers to alleviate the parlous peripheral education system, the discursive expansion that had occurred within state-connected social groups could not be extended downwards through civil society. As a result, no broadly-held notions of citizenship comparable to those of Europe could be institutionalised. On the one hand, with neither an extensive middle-class nor an independent intelligentsia, the state was

${ }^{138}$ See Frey, F. (1964) p. 211. 
able to pursue autonomously a policy of top-down, militarised statereinforcement. On the other, however, such centrist and anti-clerical despotism was an ineffectual means of maintaining peripheral support. While the Kemalists were initially careful to connect their approach to state-reinforcement to traditional ideological networks, the highly centralised and militarised bureaucracy of the republic proved neither capable of fully eradicating provincial state-subverting nationalism nor of institutionalising a 'national' civil society. In contrast to the European dialectic of militarism versus representation within a delimited nation-state, the Turkish state continued the Ottoman tradition of despotic autonomy with decentralising opposition still largely centred around peripheral religiosity. 


\section{Chapter Five: The Economics of Liberalisation}

This chapter looks at political and economic liberalisation in Turkey following the Second World War. The roots of industrial capitalism will be traced back through the single-party period (1924-1945) with an emphasis on the role played by the state. This is in keeping with Michael Mann's focus on centralised political power as key to economic advance, and societal change generally, in north-west Europe. In seeking to uncover the social origins of the various political and ideological alignments that emerged in Turkey during the period of Democrat Party governance in the 1950s, this chapter will concentrate on Mann's elucidation of 'class'. Here, the rural and urban groups that he identifies within European polities will be compared with those existent in Turkey during the post-war years. It is intended that this will provide a means of examining the extent to which these networks conform with, or deviate from, the pattern of European social development that he outlines. Of particular interest will be the role such organisations played in the emergence of what Mann terms the second phase of modern nationalism, that of 'industrial-capitalism'.

\section{Class and State}

Central to the social dynamics of this period (in Europe broadly from the mid-nineteenth century until the First World War), was, in Mann's parlance, the 'crystallisation' of class. He writes, "capitalism had created potentially extensive, political and (occasionally) symmetrical and dialectical classes". ${ }^{1}$ This did not, however, necessarily lead to compartmentalised social collectives cemented by a shared sense of group consciousness. Mann argues that for such perceptions of class unity to develop, four components (what he terms the IOTA model)

${ }^{1}$ Mann, M. (1993) p. 27. His parenthesis. 
are required. ${ }^{2}$ Firstly, a shared 'identity' must exist between class members. Secondly, this identity must include the perceived 'opposition' of (and to) other class interests. Thirdly, the first and second components must combine in a 'totality' that defines the class members' social situation and society in general. Fourthly, an 'alternative' to the existing power relations must be conceived. In Mann's view these criteria were not generally met. Classes, he argues, did not emerge as 'pure' features of modernity. Instead, they were divided by other networks of social interaction, both from within the relations of production and through the influence of non-economic forces.

Mann illustrates this by initially focusing on workers' political movements in Great Britain, the home of the first proletariat. He identifies two 'collectivities', additional to class, arguing that capitalist development's tendency to homogenise labour skills was less uniform than Marx and Engels believed. ${ }^{3}$ Firstly, workers may be 'segmentally' organised in interdependent relations with their employers. This is particularly the case if the skills of the labour force are highly specialised, developed through in-house training and scarce in the general job market. In these conditions workers are not easily able to leave and seek comparable positions elsewhere and employers are more reliant on their existing workforce as the costs of recruiting replacement staff are high. As a result, "employees become segregated from the mass of workers outside, and conflict becomes employerspecific, not generalizable to a class". 4 Secondly, workers may be organised within 'sectional' collectivities determined by their occupation or trade. This can be used to restrict the supply of their skills and oppose employers without recourse to a working class totality. In Britain, mid-nineteenth century trade unionism was subject to these sectional restraints. As unions moved their power base from the artisan trades to engineering, factory-floors and smelting works,

\footnotetext{
${ }^{2}$ See also his original formulation of these criteria (1973, p. 13).

${ }^{3}$ Mann, M. (1993) Ch. 15.
} 
they sought to avoid state harassment under conspiracy legislation by retaining what Mann calls "privileged craft sectionalism" instead of a more generalist extensiveness. ${ }^{5}$ Although many trade unionists began to view society as an economic totality within a broader capitalist system, collaboration with middle-class reformers and employers remained the norm with violent confrontations mainly restricted to the mining industry. In all, Mann concludes that "identity with the sectional trade and with the segmental enterprise strengthened more than with class". 6

The European agrarian sector has also been subject to comparable segmental and sectional cleavages which imposed varying levels of cross-class divisions on the three broad agricultural classes that Mann identifies, namely large-estate farmers, peasants (or smallholding farm proprietors) and landless labourers. ${ }^{7}$ The first, the land-owners (gentry and commoner), made up a fundamental element of both the old and the new ruling European regime and were therefore less subject to these structures. While divided by employment status, ${ }^{8}$ the power relations of the third group, the landless labourers, were, for the most part, similarly straightforward. Exploited and segmentalised by the estates and by wealthier, market-orientated smallholders they were generally unable to develop organisational links with any significant extensiveness and remained, for the most part, a latent class. ${ }^{9}$ The second group, the peasantry, was more complex. While Marx held the view that the fragmented nature of their mode of production made them incapable of class organisation, Mann, augmenting the theses of Weber, Tilly and Kautsky, argues that what he terms "the global commercialisation of agriculture" did in fact lead to the

4 Ibid. p. 511.

5 Ibid. p. 536.

6 Ibid.

7 Ibid. p. 694.

8 Mann writes that they may be "casual, seasonal or permanent, waged or paid in kind, free or bonded" (ibid.).

9 Nevertheless Mann acknowledges that exceptions to this do exist. For instance, socialist agitation did have some success, particularly in regions dominated by 
"proletarianisation" of the European peasantry. ${ }^{10}$ The employment requirements of industrialisation and improvements in transportation in the mid-nineteenth century both integrated the rural and the urban within states and brought continental landmasses closer together. As these developments favoured farmers with capital to invest, borrowing rose resulting in intensified credit conflicts and social stratification. The more successful smallholders specialised, organised distribution networks and competed with the larger estates, while others were threatened by foreclosure and forced into crop liens. Both called for improved credit terms, greater financial regulation, a standardisation of seed, fertiliser and machinery supply and an end to the collusion of urban corporations and rural capital. Mann concludes that this 'class populism' pitted 'the 'people' against corporate capitalism, potentially uniting peasants and workers, with similar opponents, in a Leftist alliance". ${ }^{11}$ Like the urban proletariat, however, increased market competition also intensified sectional divisions. Greater specialisation and interdependence made producers more vulnerable to the effects of agricultural depressions, natural disasters, regional technological advance and state protectionist policies and therefore more inclined to form local organisational networks based around their own cultivation. This meant that the peasantry, like the estate farmers and the landless, remained segmentally divided from other agrarian class members outside their locality. Such cross-class linkages led to a more general sectional division between agriculturists and urbanites, often based on the rural influence of old regime and clerical traditionalism.

The middle-classes of nineteenth century Europe were similarly segmentalised. While relatively insulated from the workers by the gradual collapse of the artisan sector, their commitment to capitalism ensured a varied degree of loyalty to the ruling regime. The petite

absentee landlords, in radicalising the sharecroppers of southern Europe and western United States.

${ }^{10}$ Ibid. p. 697.

11 Ibid. p. 698. 
bourgeoisie (the first of three middle class 'fractions' identified by Mann) were owners and controllers of their means of production (typically as a family or non-contractual association) and as such experienced little exploitation. ${ }^{12}$ Discontent was minimal and their conservatism, which helped to defeat the Chartist movement in Britain for instance, persisted throughout the challenge of rising corporate power during the nineteenth century. ${ }^{13}$ The second middleclass fraction, the careerists, were generally salaried employees in corporate or state bureaucracies. Some were managers, others (predominantly women, ex-manual workers and young men) clerks and sales assistants. All were caged within disciplined, segmental and graded hierarchies which simultaneously provided career mobility and constrained collective action. The third fraction of the middle-classes were the professionals. Theirs was "a 'learned' (involving technically and culturally valued knowledge) occupation requiring special education, whose practice is formally licensed after negotiation between the state and an occupational organisation". ${ }^{14}$ The success of the state in authoritatively controlling qualification processes (with the exception of the medical profession) and establishing regulatory supervision in most sectors restrained the autonomy inherent in the quasi-capitalist partnerships and price-fixing monopolies of feecharging professionalism.

Indeed, the role of the state is, for Mann, a key determinant in the rise of extreme right-wing politics during the 'industrial-capitalist' phase of modern nationalism. State expansion began to adopt a greater number of civilian functions. Spending on the requirements of economic growth, such as the communications and educational infrastructure had, in most European states, overtaken military

12 Ibid. Ch. 16.

${ }^{13}$ Here Mann rejects the argument that the petite bourgeoisie were proletarianised by the growth of economies of scale. Their decline, he suggests, was relative rather than absolute and mainly occurred following the Second World War. In general, they maintained prosperity levels through diversification and did not suffer the 'status-panic' which is sometimes ascribed causal value in explaining the rise of extreme Rightist politics during the 1920s and 30s (ibid. pp 557-558). 
expenditure by the early twentieth century. As Mann comments, "welfare and fiscal policies redistributed resources between regions, age-groups and classes, reducing inequalities and further solidifying the nation". ${ }^{15}$ This tended to reduce mass deference to the old regime and extend notions of popular sovereignty, previously the preserve of the bourgeoisie, into the proletariat and the peasantry. The result was threefold. ${ }^{16}$ Firstly, the ruling classes responded by using religious affiliation as a means of challenging the appeal of socialism. The social welfare associations of Catholic landowners were, for instance, particularly effective in maintaining peasant deference in southern Germany, France and Austria. Secondly, a more secular brand of conservatism appeared in northern Germany, Britain and the United States which stressed the greater tecbnocratic value of the existing relations of production. Parties hitherto dominated by landed interests increasingly emphasised their members' professional aptitude to manage a modern economy.

Thirdly, an inwardly-directed brand of industrial-capitalist nationalism emerged. Predicated on the idea of the internal enemy and propagated by 'top-down' authoritarian or semi-authoritarian rulingclass regimes, it was primarily extended through ideologically integrated state bureaucracies. This was particularly true in Germany during the early years of the twentieth century where it was used by the old regime to bring "the middle classes into the edges of the state in order to keep labour and the ethnic minorities well outside it". ${ }^{17}$ Unlike liberal countries that were more subject to the control of mass political parties, Germany and, to some extent, Austria developed highly statist, anti-proletarian segments of the bourgeoisie. Since few within the entrepreneurial sector wished for a greater extractive role for the state, it was largely within these state-affiliated professionals, public administrators and civil servants (i.e. those who had received

${ }^{14}$ Ibid. p. 564.

${ }^{15}$ Mann, M. (1995) p. 54.

${ }^{16}$ Summarised in Mann, M. (1995a) pp 27-35.

${ }^{17}$ Mann, M. (1993) p. 584. 
the most extensive state education) that support for old regime militarism (still around 40 per cent of many European national budgets) centred. ${ }^{18}$ As this evolved into what Mann terms 'aggressive' forms of nationalism, it gradually took on a violent chauvinism (often directed against transnational ideologies such as anarchism and socialism) largely beyond old regime control.

In this sense, ideological, military and political networks of social organisation "have welded solidarities among these economically heterogeneous fractions, strata and segments". ${ }^{19}$ Modern classes and class consciousness have, Mann argues, emerged from the interaction of all four sources of social power. Revolutionary politics, in both its nationalist and internationalist forms, emerged as imperfect 'crystallisations' of class sentiment from the tensions within civil society and, perhaps most importantly, between civil society and the state. While ideological and military power exerted a more ambiguous influence over class development, centralised political power "played a very substantial structuring role" in the mobilisation of class sentiment. ${ }^{20}$ Ideological relations of the 'industrial-capitalist' period were certainly important in articulating class interests, but they were a phenomenon rooted in an already constituted structure of social stratification which they could reinforce or transcend. Similarly, military recruitment may train revolutionaries, as Engels believed, or, as Mann suggests, serve to segmentalise subordinate classes, strengthening the organisational power of the old regime. In contrast, both the extension of state infra-structure and access to the state itself were determining factors in the formation of capitalist stratification and the course of inter-class relations during the late nineteenth and early twentieth centuries.

${ }^{18}$ See Mann's analysis of the German Nayy League, The Society of the Eastern Marches and the Pan German League 1900-1914 (1993) pp 585-586.

${ }^{19}$ Ibid. p. 29.

${ }^{20}$ Ibid. p. 30. 
Late Development and the Turkish Bureaucratic-Industrial Complex

As industrialisation greatly increased the power of the dominant classes, it became quickly diffused. Outside north-western Europe, social elites noted the course of earlier development patterns and established adapted models of industrial advance, inadvertently furthering state centralisation. Mann argues, after Gershenkron, that key attributes in the success of 'latecomer' industrialisation were (1) rapid growth, (2) an emphasis on producers' goods, (3) large-scale plant and enterprise, (4) increased mass consumption, (5) a diminished role for agriculture, (6) an active financial sector and (7) an interventionist state. ${ }^{21}$ This collaboration between state and capital led to subsidised manufacturing and banking systems and the promotion of cartels large enough to invest in technology and research. If, however, development was erratic or sectionally variable what Mann terms 'enclaves' may emerge in which 'comprador' classes could institutionalise transnational links seeking "to keep their own state weak and ally with foreign capital, even with foreign states". ${ }^{22}$ Such uneven development often exacerbated regional and class tensions destabilising the economy and forcing political elites to focus on issues of internal order. Following the relative stability of the first wave of late developers (Prussia-Germany, Sweden and Japan), Austrian and Russian industrialisation was successful only at the cost of territorial disintegration.

Turkey, the remnants of the other great European 'empire of domination', was, like Austria and Russia, heavily reliant on agricultural exports as a means of paying for imported capital goods and therefore shared the sectoral discrepancies of its old enemies. ${ }^{23}$

\footnotetext{
21 Ibid. p. 492.

22 Ibid.

${ }^{23}$ This was particularly the case in Turkey where the terms of the 1923 Treaty of Lausanne had forbade the government from pursuing a protectionist trade policy leaving foreign capital free to take over abandoned Greek businesses (See Keyder, C., 1987b, pp 32-33). A further point to note is the highly agrarian nature of the Turkish economy. In the 1927 census 81 per cent of the Turkish labour force were
} 
Reform generally involved core-peripheral conflict as the degree to which the state was able to influence agricultural producers was limited by the inherent autonomy of an agrarian system yet to be proletarianised by the proliferation of large-scale estates. While smallholders predominated, ${ }^{24}$ the possibility of a withdrawal from the market to the level of subsistence gave the peasantry (landless labourers obviously had no surplus with which to bargain) greater distance from the policies of the centre than the industrial and commercial sectors. In response, the state had, according to Farük Birtek and Çağlar Keyder, any combination of three possible strategies. ${ }^{25}$ The first was a mixture of taxation and acquisitive pricefixing. The second was regulation or influencing market prices by fixing the cost of inputs like land, machinery and fertiliser. The third was controlling production through measures such as land distribution/reclamation, import subsidies and credit policies.

For much of the 1920s, support of the large, export-orientated farmers, as both a means of institutionalising controls over transnational exchange and a valuable source of surplus extraction, dominated the Kemalist state's development policies. Tax burdens were lessened with the abolition of the land tithe in 1925, rail subsidies were announced and the profitable estates of the recently expelled Greek farmers of the Aegean region were allocated to Muslim land-owners. ${ }^{26}$ In 1924 the Ministry of Agriculture was created which, through its partnership with the Agricultural Bank (Ziraat Bankası), extended lending in this sector from 17 million lira in 1924 to 36 million in 1930.27 Supported by an increase in road $(22,000 \mathrm{~km}$ to $30,000 \mathrm{~km})$ and railway $(4,000 \mathrm{~km}$ to $6,000 \mathrm{~km})$

employed in the agricultural sector (Iş1kl, A., 1987, p. 312). This compares with 59 per cent in Russia in 1897, 57 per cent in Austria in 1910 and 9 per cent in Britain in 1911 (Mann, M., 1993, p. 693).

${ }^{24}$ Reşat Aktan, writing in 1957, suggests that 97 per cent of the total number of agricultural holdings during the 1930s were less than 50 hectares in area and around 8-10 per cent of all farmers did not own their own land (pp 274-275).

${ }^{25}$ Birtek, F. \& Keyder, Ç. (1975) p. 448.

${ }^{26}$ See McCarthey, J. (1980) p. 70.

${ }^{27}$ Margulies, R. \& Ylddıoğlu, E. (1987) p. 273. 
construction over the same period, ${ }^{28}$ the state had some success in increasing productivity. Although agricultural output did increase between 1923 and 1929,29 only the largest and most profitable estates were 'marketised'. As Zvi Hershlag puts it, "in spite of a general trend towards increase in agricultural output... the shortcomings were still overwhelming". ${ }^{30}$ As a result, the export drive had only minimal effects of the balance of trade. The deficit was 60 million lira in 1923 and 50 million in $1928 .{ }^{31}$

The 1929 crash worsened the situation considerably. Coinciding with a number of poor harvests, it halved the value of Turkey's five major exports, ${ }^{32}$ and had, by 1932, reduced total export revenues by between 30 and 50 per cent. ${ }^{33}$ As a result, the limited progress of smallholder incorporation into world markets was arrested, the estatefarmers lost the surpluses that had underpinned a favourable alliance with the state and Turkey abandoned liberal integrationism. In response, agricultural policy aims changed. Food production surpluses were required not for export, but in order to offset the contraction in the domestic economy caused by the curtailment of imports. These declined from 256 million lira in 1929 to 85 million in 1932, of which up to 20 per cent (the figure for 1925) were food stuffs. ${ }^{34}$ The state moved away from supporting large, export-orientated farmers and towards the cereal producer, an agricultural section dominated by smallholders. It embarked upon a price subsidising policy which established the government, through its network of purchasing stations, as the primary buyer of first, wheat, and later, barley and oats. Thus "by cutting down on imports and controlling commodity exchange in general the state put the large farmer at a disadvantage". ${ }^{35}$

\footnotetext{
28 Ibid. p. 286, n. 7.

${ }^{29}$ See Keyder, Ç. (1981) pp 38-42.

${ }^{30} \mathrm{He}$ suggests a figure of 58 per cent as an increase in agricultural production between 1923 and 1932 would be more accurate. Hershlag, Z. (1968) p. 51.

${ }^{31}$ Keyder, Ç. (1981) p. 76.

${ }^{32}$ Margulies, R. \& Yildızoğlu, E. (1987) p. 273.

${ }^{33}$ Kindleberger, C. (1973) p. 191.

${ }^{34}$ See Margulies, R. \& Yildızoğlu, E. (1987) p. 274 and Okyar, O. (1965) p. 99.

${ }^{35}$ Birtek, F. \& Keyder, Ç. (1975) p. 452.
} 
Rather than tractors and Derv being imported on Ministry-sponsored terms, the government restricted speculative investment and redistributed barely viable plots of land more suited to the labour intensive inputs of small-surplus peasants. ${ }^{36}$ During the Second World War the state increased its purchases of unused peasant produce. However, despite the inflationary pressures of mass conscription and a general shortage of consumer goods, which pushed up the general price index by 450 per cent between 1939 and 1944, the government fixed its purchasing prices. ${ }^{37}$ With prices in other economic sectors rising rapidly, profitable smallholdings that were too marketorientated to return to subsistence levels suffered a sharp fall in living standards and attempted to withhold their surpluses from the state. As a result, agricultural production declined from an index fix of 100 in 1939 to 70.4 in $1944 .{ }^{38}$ In all, this gave rise to a social stratum of significant size that was "mobilised and integrated into the economy, yet left most vulnerable to the economic downturns, and hence readily motivated to play a role in the political sphere".39

The crash of 1929 also profoundly affected the Turkish state's relationship with the urban classes. Industrial policy during the $1920 \mathrm{~s}$ had been determined by the free trade stipulations of the Treaty of Lausanne. While not entirely unprotected, the Turkish economy had relatively low tariffs (11-12 per cent on textiles and 7 per cent on metals, for instance)..$^{40}$ This 'mixed economy' approach had seen some state activity in the industrial sector, but public enterprise was not intended to usurp decentralised entrepreneurial endeavour. ${ }^{41}$ As a result of the 1929 crisis, however, an etatist policy was adopted which

\footnotetext{
${ }^{36}$ See Hershlag, Z. (1968) pp 78-79.

${ }^{37}$ Birtek and Keyder note that while over a million men were taken out of the active labour force, families that cultivated large plots were exempted. This, they argue, had the effect of reducing the amount of land under cultivation and restricting the surplus of the smallholder, thereby pushing up prices (1975) p. 459.

${ }^{38}$ Yerasimos, S. (1987) p. 90.

${ }^{39}$ Birtek, F. \& Keyder, Ç. (1975) p. 460.

${ }^{40}$ Hale, W. (1984) p. 155.

41 For example, Gündüz Okcün calculates that foreign investment was able to establish a 43 per cent share of Turkish corporate capital during this period (cited in Keyder, C.., 1981, p. 100).
} 
favoured "direct state participation, ownership and planning of the economy". ${ }^{42}$ This was influenced by the Soviet model of central planning and a loan of $\$ 18$ million offered by Moscow in 1933 on very favourable terms. ${ }^{43}$ Intellectual currents within Turkey also favoured greater state planning. The periodical Kadro (first published in 1932), for example, called for a small elite to take charge of the development process. ${ }^{44}$ This was, in part a least, effected under the first Five Year Plan (inaugurated in 1934) which established public investment and state-led enterprises as the principal mechanism of industrialisation. Although the state was at pains to stress that this did not represent an attempt to eliminate private initiative, it resulted in "a noncompetitive, closed economy dominated by state monopolies that were ...managed primarily for the benefit of a privileged elite controlling the state apparatus". 45 The distance between the state bureaucracy and the masses was further widened by the failure of government policy to produce any sustained growth in the agricultural sector. Whereas industrial output was doubled from the 1929 slump to the end of the first Five Year Plan in 1939, agricultural output had, by the end of the Second Five Year Plan in 1944, fallen back to virtually the same levels as 1929 with national income per capita actually declining over the same period. ${ }^{46}$.

During the 1930s, the state's bureaucratic elite was able to institutionalise a considerable degree of autonomy. Following the closure of a short-lived opposition party, the Free Republican Party (Serbest Cumburiyet Firkast), which had emerged in the aftermath of the 1929 crash, the elite was "left unhindered to formulate the ideology underlying the new role of the state and its socio-economic

\footnotetext{
42 Mehmet, O. (1983) p. 52.

${ }^{43}$ See Thomberg, M, Spry, G. \& Souls, G. (1949) pp 26-27.

44 See Okyar, O. (1965) p. 100.

45 Mehmet, O. (1983) p. 53.

46 With a base index of 100 taken in 1938, Alec Alexander calculates that industrial production was at 57 in 1929 and 114 in 1939 (rising unsteadily through the war to 128 in 1945), agricultural production was at 73 in 1929 and 74 in 1945 and national income per capita 85 in 1929 and 78 in 1945 (1961, p. 474).
} 
practices". 47 As Frederick Frey has found, senior civil servants and bureaucrats held many of the key positions of power in the National Assembly between 1931 and 1943. Two-thirds of the entire electoral body were continually returned to office throughout this period and the proportion of deputies born in their constituency went down from 62 per cent in 1920 to 34 per cent in 1935.48 As Kemal's party dictatorship stabilised, bureaucratic and political power merged "to create an apparatus to impose [their perception of the national] will on the public". ${ }^{49}$ In the tradition of the Ottoman ruling elite, the state attempted to direct the economic, political and ideological aspirations of 'the people' (defined as "a unified mass without class or privilege") without seeking to institutionalise mechanisms of social representation..$^{50}$ The bureaucracy's prominent position in the economy led to what Keyder calls "a seamless coalition" being formed with a small cadre of industrial magnates. ${ }^{51}$ Such corporatism was supported by the suppression of trade union movements and workers' organisations. Legislation, modelled on Italian fascism, ${ }^{52}$ in 1935, 1936 and 1938 effectively criminalised strike action and prohibited the formation of associations based on social class. As a result, the "developing bourgeoisie was an exceptionally 'national' one in its practical orientation. Deprived of a strong international connection... it became a full supporter of the centrality of the state.

\footnotetext{
${ }^{47}$ Keyder, C.. (1987b) p. 35.

48 Frey, F. (1965) passim. He also noted that up 46 per cent of deputies elected between 1920 and 1950 were from a state bureaucratic background despite making up only 3-6 per cent of the country's economically active males.

${ }^{49}$ Riggs, F. (1964) p. 265. My parenthesis.

${ }^{50}$ Işıkl, A. (1987) p. 313. Farük Birtek notes that "social mobility and membership in the urban and semi-urban professional middle class (in particular, teachers, judges and state officials) depended on their participation in the expansion of the Kemalist state. In turn the achievement of higher social status necessarily involved the rejection of local hierarchies, organisation, and traditional ties... There had been no social revolution, however, the CHP [RPP], basing its power on limited social participation and its ability to recruit a substantial part of the local elite, controlled the state by distancing the centre from - rather than attempting to transform or incorporate - the cultural periphery in the countryside" (1994, p. 225). His parenthesis.

${ }^{51}$ Keyder, Ç. (1987b) p. 36.

52 See Ibid.
} 
Thus, there was no desire on the part of the bourgeoisie to challenge the normative concerns of the bureaucracy". 53

Some writers have argued that the state's autonomy of both landed interests and an extensive, politically active capitalist class explains why it was not obliged to employ widespread military force to achieve its transformational goals. ${ }^{54}$ However, despite the state's increasingly consolidated socio-economic position, the 1930s saw little change in the martial administration of many south-east Anatolian provinces. A rebellion of approximately 5,000 Kurds around Ağri in 1930, for instance, was brutally suppressed with a force of 50,000 Turkish troops. According to David McDowall, state forces executed all 1,500 prisoners and killed over 3,000 non-combatants, before issuing a decree (Law 1850) stating that "murders and other actions committed ...by representatives of the state or province, by the military or civil authorities... or by any civilian having helped the above... will not be considered as crimes".55 In support of these measures, the then Minister of Justice announced that, "those who are not of pure Turkish stock can only have one right in this country, the right to be servants and slaves". 56 In June 1934 further legislation (Law 2510) was enacted giving the state extended powers to evacuate, and relocate to western Anatolia, all regions defined as non-Turkish. While logistical problems prevented a full implementation, reports from refugees suggest that "massacres, deportations and forced assimilation were proceeding apace" in many south-eastern provinces. 57 The destruction, in 1937, of the partly Kurdish Alevi town of Dersim, later given the Turkish name 'Tunçeli' ('the bronze hand'), with the loss of up to 40,000 lives, was a case in point. ${ }^{58}$

\footnotetext{
53 Keyder, C.. (1987) p. 199.

${ }^{54} \mathrm{See}$ Ozbudun, E. (1981) pp 95-96 for instance.

${ }^{55}$ McDowall, D. (1993) pp 37-38.

56 Cited in ibid.

${ }^{57}$ McDowall, D. (1992) p. 207.

${ }^{58}$ Rambout's estimate cited in ibid.
} 
While these measures were influenced by the fascist regimes of contemporary Europe, particularly that of Germany with whom Turkey signed a large-scale trade agreement in 1935,59 they were primarily based on a belief in the practical efficacy of social engineering rather than ideologically grounded in socio-biological notions of ethnic difference. In other words, discrimination against non-Turkish identities was part of a search for greater social cohesion within the ideological framework of industrial-capitalist advance (discussed below) rather than the deliberately divisive 'otherisation' measures of Hitler's Germany. Having rejected the republic's Ottoman heritage as obscurant and atavistic, Kemalist visions of an idealised 'national' heritage were vague and lacked the Nazi's ideological construction of the past as an attainable and worthy social goal. Non-Turks could, through individual or state action, become citizens - an option not commonly available to non-Germans under Nazi administration. In keeping with fascist regimes in Europe, however, this denial of the utility of ethnicity coincided with a general rejection of religiosity and social stratification. In this sense, Stephane Yerasimos was correct to conclude that "the role assigned to the party, the denial of social classes and their replacement by occupational bodies, the foreign pressures under which the republic and the party were founded, and the orientation toward racist reference points in the search of a national culture and history, had all predisposed them [Kemal's political elite] to a fascist inclination". 60

It was, however, the Turkish state's attempts to extend its political power that was at the heart of these developments, not an ideological construct pursued for its own sake. Efforts to increase the centre's infra-structural reach into south-eastern Anatolia produced chauvinist effects which became increasingly incorporated into a national education system primarily aimed at grooming future public administrators as resistance to its extractive and tutelary policies were

\footnotetext{
${ }^{59}$ According to Keyder (after Fleury) Germany received 51 per cent of Turkey's exports from where Turkey bought 41 per cent of her imports (1987b) p. 37.
} 
encountered. The object of territorial homogenisation was not a purification of the 'Volk', but (as borders solidified, internal disorder lessened and the Lausanne restrictions expired) the etatist management of a national economy through the disempowerment of peripheral comprador agents. To return to Gershenkron's seven point model highlighted earlier, successful latecomer industrialisation could only be effected through state intervention. In order to prevent regionally uneven development and, perhaps most importantly, the rise of class consciousness, the state must have infra-structural access to peripheral social groups. This is essential to both facilitate industrial growth and eliminate enclaves of unregulated transnational trade. Attempts were made by the Turkish administration to extend the infra-structural development schemes of the Five-Year Plans to the eastern provinces, but the bulk of state investment and public enterprises remained in western Anatolia, as did the majority of market-orientated agricultural estates. ${ }^{61}$ In all, military measures such as relocation and forced assimilation were preferred to developmental policies as a means of curtailing decentralised transnational trade ${ }^{62}$ In the tradition of Ottoman governance, the republican state, perhaps wary of Austrian and Russian fragmentation during industrialisation, placed political integration before economic development as its primary policy aim. While this may have succeeded in preventing comprador commercial groups from gaining autonomy, it could not

\footnotetext{
${ }^{60}$ Yerasimos, S. (1987) p. 90. My parenthesis.

${ }^{61}$ While noting a dearth of primary sources regarding agricultural reforms during this period, Margulies and Yildizoğlu suggest that, at least until 1937, land-owners in south-eastern provinces continued to divide up their estates along the traditional lines of sharecropping and "can be distinguished from the rest of the country by a historical background of tribal relations" (1987, p. 277). Walter Weiker writes, "factors influencing relative low levels of developmental efforts in these regions included the prospects of quicker and larger returns in the already semi-developed central areas, the need to keep order... and, possibly, the RPP's at least tacit alliance with many large landowners of the eastern region" (1981, p. 233).

62 This may be part of the reason why agriculture's share of the Turkish working population only dropped from 81 per cent in 1927 to 78 per cent by 1950 and from a 49 per cent GDP share to 43 per cent over the same period. See Tezel, Y. (1975) pp 75-86.
} 
provide the necessary "penetrative' strength" to pursue the Western model of capitalist development. ${ }^{63}$

\section{Democratisation and the Challenge of the Bourgeoisie}

The Second World War affected Turkish society in a number of different ways. Within the agricultural sector, as has been already noted, the peasantry fared very badly. In contrast though, "conditions were particularly conducive to the expansion of rurally based merchant capital". ${ }^{64}$ The decrease in agricultural production, coupled with states' greater extractive needs (features of both the domestic and the world market), reduced the availability of food stuffs and pushed up prices. Abraham and Eva Hirsch note that this led to a rise of over 80 per cent in the internal terms of trade for agriculture between 1939 and 1943. ${ }^{65}$ Thus the large estate farmers, whose more substantial surpluses already allowed them to withstand better the acquisitive infra-structure of the state, were able to generate significant profits during the war by both monopolising urban supply chains and speculating on the international exchange of staple commodities. Through associated networks of traders and middlemen, these forces of agricultural mercantilism brought rural modes of production closer to urban capitalists. To this nascent entrepreneurial class, the rigid controls of etatism and its corporatist partiality were seen as unduly restrictive, corrupt and a grossly inefficient means of allocating their tax returns. ${ }^{66}$ Similarly dissatisfied were the burgeoning professional classes which the state elite had promoted, partly through a quadrupling of the literacy rate (from 6 per cent to 23 per cent in the years 1927 to 1945$),{ }^{67}$ to support their bureaucratic control of the provincial economy. Occupational groups such as lawyers, doctors and educators saw that by combining their

${ }^{63}$ Mardin, S. (1980) p. 43.

64 Margulies, R. \& Yildızoğlu, E. (1987) p. 277.

${ }^{65}$ Hirsch, A. \& Hirsch, E. (1966) p. 454.

${ }^{66}$ See Walstead, B. (1977) pp 76-77 and Tachau, F. (1973) p. 299.

67 Rustow, D. (1967) p. 19. 
interests with the local nobility, clientelistic links with the peasantry could develop constituting "a formidable alliance" against state intervention. ${ }^{68}$

The breakdown of the bureaucracy's control of the emerging bourgeoisie can be seen in the reasons behind President İsmet Inönü's (Kemal had died in 1938) decision not to appoint candidates for six by-elections held in June 1945. This was followed in September by an announcement sanctioning the establishment of an official party in opposition to the Republican People's Party (Cumburiyet Halk Partisi - RPP) which had monopolised constitutional politics since the inception of the republic. Cem Eroğul offers four explanations to account for these early moves towards political liberalisation. ${ }^{69}$ Firstly, they were to appease the peasantry (still around 80 per cent of the population) who had been alienated by wartime austerity and top-down modernisation. Secondly, they were a response to the breakdown in international relations with the Soviet Union and the need to move closer to the West. Thirdly, they were simply another step along the path of Westernisation begun in the years of the Tanzimat. Fourthly, they were an attempt to allay the propertied classes' dismay at the RPP's land reform initiative which stipulated that all private holdings of more than 500 hectares (in some cases it was to be 200) would be expropriated by the state and redistributed amongst subsistence farmers. Land that was cultivated by sharecroppers and tenants was to be seized and reallocated regardless of size. Although heavily supported by the militarybureaucratic-intellectual wing of the Party as an attempt to both nurture a franchise base and reassert centralised state power over the rich farmers, implementation was reliant on the co-operation of local landowners and merchants and therefore impossible. ${ }^{70}$ Such an Ottoman-type measure was highly unpopular amongst a wide section

${ }^{68}$ Mardin, S. (1980) p. 42.

${ }^{69}$ Eroğul, C. (1987) pp 102-103.

70 Only 3,600 hectares were expropriated forcing the resignation of the Minister of Agriculture (Özbudun, E. 1970 p. 398). 
of the bourgeoisie where it was seen as illiberal and likely to lead to a decrease in productivity levels. ${ }^{71}$

Table Nine: The Birthplace of Political and Bureaucratic Elites. ${ }^{72}$

\begin{tabular}{lcccccc}
\hline & & 1943 & & & 1946 & \multicolumn{2}{c}{1954} \\
Region of Birth & Pol. & Bur. & Pol. & Bur. & Pol. & Bur. \\
\hline Western & 54 & 62 & 44 & 51 & 31 & 41 \\
Central & 26 & 33 & 36 & 44 & 45 & 43 \\
Eastern & 8 & 0 & 14 & 6 & 17 & 13 \\
Outside Turkey & 12 & 6 & 5 & 2 & 7 & 2 \\
\hline
\end{tabular}

So, while Inönü was successful in ensuring that the rival party (the Demokrat Parti - DP) was initiated by loyal members of the RPP without Leftist sympathies, he was unprepared for the instant popularity it commanded, especially among the provinces. In what Özbudun describes as "a typical centre-periphery issue" the DP "advocated less strict government controls and a greater reliance on market and/or local forces - in other words more power for the periphery". ${ }^{73}$ The RPP, on the other hand, remained dominated by urban intellectuals and bureaucrats disassociated from both the small to medium sized market-orientated farmers, who had forged decentralised links with urban entrepreneurial groups, and the rural masses. ${ }^{74}$ Although opposed to land reform, sharing the RPP's low institutional penetration of rural society and lacking a clear ideological position, the DP were able to gain peasant support by promising lower taxes, less state intervention and "by rewarding regional cliques, kinship ties, religious demands and personal influence networks". 75 This led to provincial Party moieties based on micro-factors ingrained in localised power networks from which it is difficult to draw national

71 See Ahmad, F. (1977) p. 11.

72 Source: Roos, N. \& Roos, L. (1968) p. 290.

73 Ozbudn, E. (1980) p. 58.

${ }^{74}$ For an overlapping, but slightly different view, see Karpat, K. (1962) p. 310.

75 Sunar, I. \& Sayarn, S. (1986) p. 173. 
generalisations. ${ }^{76}$ Nonetheless, it can be seen from the 1950 election results that the DP was initially less able to gain support in south-east Anatolia. Within the fifteen provinces where Kurdish makes up more than 15 per cent of the population's mother tongue, the RPP received 53.4 per cent of the vote compared to a national average of 39.9 per cent, the DP's share was 43.7 per cent with a 53.3 per cent average. ${ }^{77}$ In these areas the carrot and stick of militarised corporatism had institutionalised support for the state bureaucracy amongst local elites whose feudatory position had not been undermined by advances in rural merchant capital. As a result, the peasantry continued to be "deeply subservient" to the landlord/cleric alliance. ${ }^{78}$ By the 1954 election, however, the DP had, as Table Nine shows, presided over an increase in Eastern Anatolian representation within the political elite. They secured fatwas from eminent sheikhs reaffirming the sanctity of private property in Islam thereby keeping the possible benefits of land reform off the agenda and successfully obtaining the support of numerous south-eastern landowners. As a result, the DP won 34 out of the 40 seats in the south-east. ${ }^{79}$

In all, then, the DP's election victory in 1950 and subsequent consolidation in 1954 "can be seen as a decisive shift in Turkey's history from elite rule to full class rule and from one pattern of capitalist development to another". ${ }^{80}$ The bureaucratic state elite was replaced by an administration empowered and maintained by decentralised organisational networks located primarily in the periphery. ${ }^{81}$ As claimant to the guardianship of state values since the

\footnotetext{
${ }^{76}$ See Rustow, D. (1966) p. 123.

77 Kirişci, K. \& Winrow, G. (1997) pp 106-107. See also Tachau, F. \& Good, M. (1973) pp 563-564.

${ }_{78}$ McDowall, D. (1992) pp 397-399. Sabri Sayan writes "Unlike other parts of the country, traditional patron-client ties rather than party patronage are of primary importance in the structuring of political loyalties"(1977, p. 110). See also Kudat, A. (1975) passim.

${ }^{79}$ See McDowall, D. (1992) p. 398.

${ }^{80}$ Keyder, C.. (1987b) p. 40.

${ }^{81}$ Arnold Leder comments that the DP made every effort "to present themselves as the champions of the periphery against the hated centre" (1979 p. 84).
} 
days of the örfi sultani, ${ }^{82}$ the bureaucracy had long been at the forefront of an 'induced' process of social change and was slow to adapt to "the weakening of the deferential political culture of the countryside" now apparent in Ankara. ${ }^{83}$ As a result, "the bureaucratic response to the demands of the DP government and the provincial leadership was slow, and often negative". ${ }^{84}$ The DP leadership, under Premier Adnan Menderes, reacted in three ways. The first was to reduce the status of the civil and armed services by circumventing their decision-making hierarchies. ${ }^{85}$ This was achieved by appointing DP supporters to positions of power, the dismissal of the entire army command within a month of the 1950 elections and by appealing directly to the masses through the extension of RPP legislation relaxing bureaucratic controls on the practice of Islam. ${ }^{86}$ Secondly, the government allowed salary levels within the public sector to drop during the highly inflationary period of the mid-1950s. ${ }^{87}$

The third measure the DP adopted was an attempt to outflank the bureaucracy's instrumental role in regulating social change through the promotion of 'organic' modifications within its power base, the agricultural sector. To bring the provinces closer to the economy of the centre, a large-scale highway building programme was undertaken. This increased all-weather roads from a national total of 17,000 kilometres in 1950 to 39,000 in $1960 .{ }^{88}$ Exploiting the close ties that the RPP had developed with the United States in the post-war years, ${ }^{89}$ the government used Turkey's key position in John Foster Dulles' concept of an anti-Soviet, Middle Eastern 'northern tier' to generate "a cornucopia of subsidies". ${ }^{0}$ This aid, coupled with earnings from an export boom in the early 1950s, was invested in agriculture

\footnotetext{
${ }^{82}$ See Heper, M. (1979-80) passim.

${ }^{83}$ Sayan, S. (1977) p. 109.

${ }^{84}$ Turan, İ. (1984) p. 114.

${ }^{85}$ See Heper, M. (1984a) p. 74 \& (1990) p. 218.

${ }^{86}$ See Eroğul, C. (1987) p. 107 and Sarıbay, A. (1991) p. 129.

${ }^{87}$ See Turan, I. (1984) pp 114-115.

88 Ulman, A. \& Tachau, F. (1965) p. 154.

89 Turkey had received $\$ 391$ million dollars through the Marshall Plan between 1946 and 1950 (Schick, I. \& Tonak, E., 1987, p. 340).
} 
through the extension of state assistance to large landholders. ${ }^{91} \mathrm{~A}$ price-fixing scheme was revived in which the state paid more than the market price for agricultural surpluses increasing the public cost from 23 million lira in 1949-1950 to 519 million in $1954 .{ }^{92}$

Table Ten: Numbers of Selected Farm Machinery 1948-54.93

\begin{tabular}{lrrr}
\hline & 1948 & 1952 & 1954 \\
\hline Tractors & 1756 & 31415 & 37740 \\
Ploughs (Tractor-drawn) & 1472 & 30766 & 38000 \\
Trailers & 140 & 12982 & 18088 \\
Disc Harrows (Tractor-drawn) & 680 & 9623 & 14097 \\
Cultivators (Tractor-drawn) & 401 & 4028 & 5075 \\
Graindrills (Tractor-drawn) & 162 & 4406 & 6870 \\
Cotton Planters & 2570 & 13909 & $\ldots \ldots$. \\
Reapers & 14384 & 21122 & 19782 \\
Combines & 268 & 3222 & 4705 \\
Threshers & 430 & 959 & 1220 \\
Hay Mowers & 612 & 1553 & 3159 \\
\hline
\end{tabular}

In addition, financial credits allowing landlords to mechanise large estates increased from 3 million lira for the period 1945-50 to 9.7 million for 1950-1956.94 As Table Ten shows, such stimuli had a significant effect on mechanised agricultural input levels. Supported by a number of exceptionally good harvests and high commodity prices provoked by the war in Korea, they led to an increase of 50 per cent in agricultural output between 1950 and $1958 .{ }^{95}$ Furthermore, with the imperatives of a quickly growing populace, ${ }^{96}$ the total amount of land under cultivation was also increased from 11 million to 17 million hectares between 1950 and 1959.97

\footnotetext{
${ }^{90}$ Rustow, D. (1979) p. 87.

${ }^{91}$ See Berberoğlu, B. (1982) p. 71.

92 Ibid. p. 83, n. 12.

${ }^{93}$ Source: Aktan, R. (1957) p. 276.

${ }^{94}$ Ibid. p 71. See also Aresvik, O. (1975) p. 19.

${ }^{95}$ Simpson, D. (1965) p. 144.

${ }^{96}$ After 1950 Turkey maintained an annual population growth of almost 3 per cent. See Kolars, J. (1973, p. 191).

97 Ulusan, A. (1959) p. 129.
} 
Table Eleven: Urban and Rural Populations ${ }^{98}$

\begin{tabular}{cccccc}
\hline & $\begin{array}{c}\text { Province \& } \\
\text { District Centres }\end{array}$ & \multicolumn{5}{c}{$\begin{array}{c}\text { Sub-Districts } \\
\text { \& Villages }\end{array}$} \\
& Population & $\%$ & Population & $\%$ & Total \\
\hline 1950 & & & & & \\
1955 & $5,244,337$ & 25.0 & $15,702,851$ & 75.0 & $20,947,188$ \\
1960 & $6,927,343$ & 28.8 & $17,137,420$ & 71.2 & $24,064,793$ \\
& $8,859,731$ & 31.9 & $18,895,089$ & 68.1 & $27,754,820$ \\
\hline
\end{tabular}

In ascertaining the effects of these changes, some writers have argued that state efforts at land redistribution ensured that large-estate farmers did not increase their hold on agricultural production.9? However, while the proportion of landless village families probably did decline from around 16 to 10 per cent from 1950 to $1960,{ }^{100}$ the continual threat of land reform meant that large holdings were heavily underreported. Moreover, the figures are further skewed, particularly in the south-east, by the practice of employing small farmers, recently rendered landless by mechanised inputs, as subsistence tenants on large-estates in order to secure their voting allegiance and "remain attractive to the political parties". ${ }^{101}$ As a result, a more accurate figure may be Berberoğlu's estimate that, by 1957, between 18 and 20 per cent of all cultivated land was operated by large-estate capital. ${ }^{102}$ Indeed, Reşat Atkan has found that all farmers investing in mechanisation were able to increase the size of their estates by an average of 31 per cent with plots in the south-east growing by an average of 43 per cent. ${ }^{103}$ In all, it is possible to conclude that, during this period, "thousands of middle and small farmers were driven to bankruptcy, losing their land to big landowners and joining the ranks

98 Source: Keyder, Ç. (1986) p. 297 after Devlet Istatistik Enstitüsü, Ístatistik Yzliğz (various years).

99 Indeed, statistics show that the number of large holdings (20 or more hectares) actually declined from 145,000 in 1952 to 115,000 in 1963. See Margulies, R. \& Yildızoğlu, E. (1987) p. 283.

${ }^{100}$ Keyder, C.. (1987) p. 131.

101 McDowall, D. (1992) p. 399.

102 Berberoğlu, B. (1982) p. 71. 
of the rural unemployed and underemployed or migrating to urban centres in search of work". 104 By 1953, Kemal Karpat states that mechanisation had already dislocated over one million farmers with urban migration, shown in Table Eleven, further exacerbated by an economic down-turn the following year. ${ }^{105}$

Before the recession of the mid-1950s, the DP had pursued the threefold economic recommendations made by the International Bank for Reconstruction and Development (IBRD - now the World Bank) in 1951.106 Firstly, the state withdrew a considerable proportion of its investments in industry. As a result, private capital's share of manufacturing increased from 58 per cent in 1950 to 65 per cent in 1954 and the number of joint-stock companies rose from three to fifty-six over the same period. ${ }^{107}$ Secondly, favourable foreign investment conditions were introduced which eventually led to "the gradual integration of the newly emergent indigenous bourgeoisie into the worldwide production process". ${ }^{108}$ Direct investment from the United States alone rose from $\$ 16$ million to $\$ 33$ million between 1950 and 1954.109 Thirdly, the DP focused development on the light manufacturing and, as we have seen, the agricultural sectors, leaving heavy industrial investment to foreign capital. ${ }^{110}$ In return for these measures Turkey received $\$ 56$ million dollars in loans from the IBRD between 1950 and 1957 and a further $\$ 100$ million from the IMF and OEEC in 1958.111 However, while the early part of this period saw a considerable increase in export levels (from 738 million lira in 1950 to 1,110 million in 1953), imports also rose leading to a trade deficit of 516 million lira in 1955.112 As a result, Turkey's national debt grew from 775 million lira in 1950 to over 5 billion in 1960 which,

\footnotetext{
${ }^{103}$ Aktan, R. (1957) p. 277.

${ }^{104}$ Berberoğlu, B. (1982) p. 71.

${ }^{105}$ Karpat, K. (1976) p. 56. See also his article of 1960 in Social Research.

106 See Berberoğlu, B. (1982) p. 81, n. 1.

${ }^{107}$ Ergil, D. (1975) pp 141-142.

108 Berberoğlu, B. (1982) p. 68.

109 Ibid. p. 82, n. 8.

${ }^{110}$ For a survey of overseas interests in Turkish corporations, see ibid. p. 70.

111 Krueger, A. (1974) p. 77.

112 Berberoğlu, B. (1982) p. 72.
} 
worsened by the governmental policy of printing ever more money, devalued the lira, led to high domestic inflation and doubled the cost of living. ${ }^{113}$

Price pressures not only acted as a 'push' factor in migration, they also stimulated housing speculation, producing a construction boom cyclically fuelled by accelerating urbanisation. ${ }^{114}$ As the building industry prospered, more migrants arrived increasing the number of urban plants employing ten or more workers from 163,000 to 324,000 in the latter half of the 1950s. ${ }^{115}$ With an average growth of more than 5 per cent per annum for each of the four largest centres of population in Turkey (Istanbul, Ankara, Izmir and Adana) between 1950 and 1975, shanty towns (or gecekondu) began to dominate most Turkish cityscapes. ${ }^{116}$ With the rapidly expanding private business sector focused on western Anatolia (63 per cent of the 401 projects the Industrial Development Bank helped to fund between 1950 and 1960 were in the Marmara region) regional disparities became increasingly apparent. ${ }^{117}$ As Table Twelve shows, the majority of migrants from the east moved westwards. The result was that many gecekondu became "permanent strongholds of Kurdish identity across the republic... mak[ing] the Kurdish question a visible reality for the citizens of Istanbul 800 miles away from Kurdistan". 118 Thus "social lines came to be drawn along geographical differences... [which] reinforced solidarities in the labour market and political rivalries were inevitably superimposed on such divisions". 119

${ }^{113}$ Hershlag, Z. (1968) p. 334 \& 338 \& Yenal, O. (1967) p. 98. See also Turan, I. (1988a) pp 77-78.

114 Kemal Karpat cites building plots in Ankara that were priced at 50 liras in 1949 and 50,000 liras in 1965 (1976) p. 57.

${ }^{115}$ See Singer, M. (1977) p. 242 and p. 295 and Dervis, K. \& Robinson, S. (1980) p. 95.

${ }^{116}$ A gecekondu is defined by Fehmi Yavuz as "those buildings, constructed hastily, in a way violating construction regulations, and generally lacking even the most primitive facilities" (cited in Saran, N., 1974, p. 329). See also Danielson, M. \& Keles, R. (1980) p. 290.

117 Bianchi, R. (1984) p. 58.

${ }^{118}$ McDowall, D. (1992) p. 402. My parenthesis.

119 Keyder, Ç. (1987) p. 206. My parenthesis. 
Despite an increase of 52 per cent in the numbers employed in industry during the $1950 \mathrm{~s}$, the urban industrial sector was unable to absorb the large numbers of migrants arriving from the countryside. ${ }^{120}$ By 1951 there was over a million people unemployed amounting to more than 50 per cent of the urban workforce. ${ }^{121}$ For those who were able to find work, wages, continually devalued by spiralling inflation, rarely provided a standard of living beyond subsistence. Attempts were made to improve conditions through unionisation which increased by 500 per cent between 1948 and $1958 .{ }^{122}$ However, while the 1947 Trade Union Act had relaxed Kemal's prohibition on "associations based on class", strike action and collective bargaining with employers remained illegal. ${ }^{123}$ Furthermore, its generous severance pay stipulations for employees of over six months' tenure meant that many firms took on workers for periods limited to five and half months thereby worsening the plight of the urban proletariat. ${ }^{124}$ Despite labour relations forming part of both parties' electoral platform during the 1950 s, few changes materialised. Since the DP were not reliant on proletarian support, the corporative relations which developed between union leaders and the state did not provide a basis for populist inducements. Contrary to contemporary Latin American examples, they were rather "used for applying strong control over the development potential of labour through anti-labour policies". 125 The DP was able to effect these restraints through three principal mechanisms. The first was the government's administration of union finances which, with a membership basis too impoverished to subscribe dues, were based on a "fund formed by the fines levied in accordance with Labour Law".126 Secondly, unions were conglomerated into the Confederation of Turkish Labour Unions (Türk-Is) in 1952. It was felt that such a centralised body would be

\footnotetext{
120 Berberoğlu, B. (1982) p. 73.

${ }^{121}$ Ahmad, F. (1977) p. 136.

${ }^{122}$ Berberoğlu, B. (1982) p. 74.

${ }^{123}$ See Hershlag, Z. (1958) p. 288.

124 See Rustow, D. (1967) p. 17.

125 Cizre-Sakalloğlu, Ũ. (1992) p. 714.

${ }^{126}$ Işıklı, A. (1987) p. 317.
} 
(and in fact proved to be) easier to influence. Thirdly, those that continued to pressure the government for concessions were "subjected to repression and persecution". 127 In all, the DP was successful in continuing the RPP's long-established suppression of left-wing political organisation.

Table Twelve: Urbanisation by Region in Percentage. ${ }^{128}$

\begin{tabular}{l|ccccc}
\hline $\begin{array}{l}\text { Year } \\
\text { Region }\end{array}$ & 1927 & 1935 & 1945 & 1955 & 1965 \\
\hline Marmara & 36.3 & 34.9 & 36.2 & 41.8 & 55.0 \\
Southern Anatolia & 19.2 & 19.1 & 21.9 & 25.8 & 33.9 \\
Aegean & 20.5 & 22.3 & 22.7 & 26.9 & 37.9 \\
Central Anatolia & 11.1 & 13.0 & 16.5 & 23.3 & 30.0 \\
Southeast Anatolia & 15.0 & 16.0 & 15.6 & 15.4 & 19.0 \\
Eastern Anatolia & 7.6 & 6.3 & 8.8 & 10.1 & 15.8 \\
Black Sea & 5.7 & 6.7 & 7.2 & 9.1 & 13.6 \\
& & & & & \\
National Average & 16.4 & 16.6 & 18.3 & 22.1 & 29.8 \\
\hline
\end{tabular}

Within the growing networks of small-scale capitalism, however, leftist sympathies did find greater room for expression. These were part of an overall expansion in the middle-classes from around 5 per cent of the total population in 1950 to more than 20 per cent by 1965 . Nezih Neyzi points to an enlargement of more than 10 per cent per annum in the numbers of registrants at the Istanbul Chamber of Commerce from 1952 to 1956 arguing that much of this had its roots in upper working class and lower middle-class entrepreneurialism. ${ }^{129}$ Initially economically supported by the liberalising DP government as a means of nurturing a client base close to the masses and beyond the RPP. orientated officialdom's control, they were largely excluded from a political discourse in which social criticism was condemned as disloyal or insurgent. However, as "earlier social values, based on education and dedication to state ideals were undermined by an order based essentially on economic power", decentralised literary networks did

127 Ibid. p. 315.

${ }^{128}$ Source: Danielson, M. \& Keles, R. (1980) p. 285.

${ }^{129}$ Neyzi, N. (1973) pp 138-139. 
begin to proliferate within urban, lower middle-class groups. ${ }^{130}$ The result of this was that "the significance of the bureaucratic elite as the modernising centre of a developing society was diminished". ${ }^{131}$

In a similar vein to the eighteenth century European novelists' "search for authentic 'use values' amid the 'degraded' materialism of a capitalism concerned only with 'exchange values"', 132 literary realism highlighting and ennobling the struggle of the peasantry gained considerable intellectual currency in Turkey during the 1950s. ${ }^{133}$ Broadly tolerated by the DP who were keen to portray their agricultural investments in a morally favourable light, many of these novels, short stories and plays were serialised in the daily press. With urban male literacy as high as 72 per cent in some cities, the demand for newspapers had increased daily circulation from 241,000 in 1948 to 412,000 by $1951 . .^{134}$ Associated with these were a number of journals, of which the bimonthly Forum (first published in 1955), formulated some of the most sophisticated critiques of Democrat policies. ${ }^{135}$ Another was Ileri Yurt (Future Homeland) which appeared in Diyarbakır in 1958. Put together by intellectually promising Kurdish émigrés who had been evacuated under the state's assimilation policy, it led a campaign (greatly encouraged by the Iraqi revolution and the return of Mullah Barzani later that year) "to develop Turkey's woefully neglected Kurdish provinces" in what was the first expression of a Kurdish identity since the Dersim revolt. ${ }^{136}$ In all, Karpat concludes, this body of "literature, written mostly in colloquial Turkish, was social in character and represented the views of lower-class intellectuals and reflected the infinite problems and aspirations of all other classes". ${ }^{137}$

\footnotetext{
${ }^{130}$ Karpat, K. (1966) pp 177-178.

131 Ibid. p. 148. Ali Kazancigil writes that "the bourgeoisie gradually took hold so that, from 1945, it could defy the power monopoly held by the state elites" (1994, p. 230).

132 Mann, M. after Lukacs and Goldmann (1975) p. 286.

133 See Karpat, K. (1960a) passim.

${ }^{134}$ Lewis, B. (1961) pp 304-305.

135 See Karpat, K. (1973b) pp 347-348.

${ }^{136} \mathrm{McD}$ owall, D. (1992) p. 403.
} 
Connected to this predominantly literary movement, were a number of mostly clandestine and illegal Leftist organisations, foremost among which was the Turkish Communist Party (Türkiye Komünist Partisi TCP). Founded by Russian émigrés soon after the First World War it sustained a degree of influence during the single-party period through occasional publications in journals such as Aydnhlik (Enlightenment). ${ }^{138}$ Nonetheless a combination of repression, absorption into state administration and factionalism prevented effective party organisation. ${ }^{139}$ Following the Second World War and the amendment of the Law of Associations, though, attempts were made by the TCP leadership to broaden the Party's social appeal. A twenty-six point programme was published in 1945 containing a strongly patriotic preamble and professing to be aimed at all independent groups hostile to the forces of reaction. Point Two, for instance, expressed the intention to form "a government out of worthy citizens clearly committed to Atatürk's reforms and the principles of democracy". ${ }^{140}$ However, calls were also issued for closer ties with the Soviet Union at a time when Stalin was pressurising Turkey over a territorial dispute in the north-east and for improved access to the Straits. ${ }^{141}$ As a result, anti-leftist measures were restored culminating in the arrest and prosecution of 167 members of TCP, including much of the leadership, in 1951. With an average age of 32.1 years, the majority (120) of this group were junior artisans and office clerks, young workers and students. ${ }^{142}$ In some ways, its youthful membership can be explained by the existence of highly active university-based organisations loosely affiliated to the TCP. Both Istanbul wings of the nominally legal Higher Education Youth Association (Yülesek Tabsil Genclik Dermegi) and The Turkish Association of Peace-Lovers (Türk Barisseverler Cemiyeti), for instance,

\footnotetext{
${ }^{137}$ Karpat, K. (1972a) p. 355.

${ }^{138}$ See Karpat, K. (1959) pp 355-356.

139 See Harris, G. (1967) Epilogue.

140 Cited in Landau, J. (1974) pp 101-102.

${ }^{141}$ See Karpat, K. (1966) p. 176. For a more detailed account of the international context, see Rustow, D. (1965) passim.

142 See Landau, J. (1974) pp 110-111.
} 
maintained a leftist populism based on a literary circulation of 48,000 and 24,000 respectively. ${ }^{143}$

Opposition to the Menderes regime also came from sectors of the bureaucracy proletarianised by the inflationary policies of the mid1950s. This 'new leftism', as Kemal Karpat puts it, had little association with the Marxism of the TCP. Not, as he continues, "a replica of a foreign ideology", 144 it emerged from domestic conditions, particularly the urban expansion of the state bureaucracy during the 1950s. Between 1950 and 1960 central government personnel alone rose from 174,000 to 314,000 leading to salary caps and, with the concurrent rise in the professional sector proving a more attractive choice for the growing body of university graduates, a severe drop in civil service prestige. ${ }^{145}$ Of the fourteen career grades, only the top seven could be considered middle-income, so, with vertical progression made extremely difficult by nepotism and favouritism, the great majority of posts provided few opportunities for social mobility. Despite being prepared "to fill administrative slots" by "a strongly patriotic education with chauvinistic overtones" at the very vanguard of statist officialdom, even the elite apparatchiks found themselves increasingly overlooked. ${ }^{146}$ As a result, Karpat concludes, "these rising social currents eventually sought legitimation in the unfulfilled social promises of Kemalism, through an expanded interpretation of its populist, statist and reformist principles". ${ }^{147} \mathrm{An}$ ideological coalition between the RPP, revivalist elements of the Kemalist intelligentsia and disaffected groups with bureaucratic officialdom emerged in opposition to the pragmatist politics of the

${ }^{143}$ Figures relate to the publication of each organisation's manifesto in 1950. See ibid. pp 114-115.

${ }^{144}$ Karpat, K. (1966) p. 179. Edwin Cohn also points to the fact that multiparty democracy "made politicians more accessible to voters and thus opened to them an alternative route for bringing their appeals to authority" (1970, p. 94).

145 Neyzi, N. (1973) p. 132.

${ }^{146}$ Landau, J. (1973) p. 277 and Mardin, Ş. (1980) p. 40 respectively. A study by $\mathrm{H}$. Hyman, A. Payaslioğlu \& F. Frey in 1958 found that the nationalist nature of the state education system had so conditioned students that they produced strongly nationalist responses to even broadly framed questions ( $\mathrm{pp}$ 282-285).

${ }^{147}$ Karpat, K. (1966) p. 179. 
DP. ${ }^{148}$ Through a greater emphasis on rational administration free from the subjective criteria and interjections of the government, they aimed to consolidate the modernist institutions and objectives of Kemal's republic and reduce the influence of religious obscurantism and reactionary conservatism. ${ }^{149}$

Nonetheless, in terms of organisational implementation Turkish civil servants remained what Metin Heper calls 'patrimonial-legalists' and did not develop the 'rational-productive' orientations required to institutionalise a neutral, apolitical public service. ${ }^{150}$ İlkay Sunar explains this by pointing to a possible discrepancy between the bureaucracy's 'manifest' values, as exemplified by an ostensible commitment to progressive reformism and more traditionally conceived 'operational' values born of perennial salary, employment security and status concerns. ${ }^{151}$ Indeed, a study published in 1955 found those considering choosing the bureaucracy as an occupational path predominantly did so on the basis of an assured permanent tenure. Of the 'emergent administrators' interviewed, 76 per cent preferred a career that promised maximum security combined with a low salary with only 7 per cent opting for 'little security; high salary' and 14 per cent for 'moderate security; moderate salary'. ${ }^{152}$ For Metin Heper, this is expressed in a propensity for conservatism and a relatively low tolerance for "democratic political life". ${ }^{153}$ In this sense, the recruitment of officials from lower socio-economic strata may have brought in "persons who [we]re even less secure and so need[ed] even more to reinforce their own sense of status" thereby offsetting any increased empathy these non-elite groups might have had with

\footnotetext{
${ }^{148}$ Many university campuses also became centres of pro-RPP activities as "students increasingly protested their frustration at what they considered the DP's sacrifice of Atatürk's reforms, as well as its repression of all political opposition" (Landau, J., 1974, p. 30).

${ }^{149}$ See Heper, M. (1984a) pp 72-73. For a study comparing popular attachment to the memory of Kemal in urban and rural areas, see George Angell's research of 1963 cited in Frey, F. (1968) pp 941-943

${ }^{150}$ Heper, M. (1981a) passim.

151 Sunar, İ. (1974) pp 136-138.

152 Matthews, A. (1955) p. 24.

${ }^{153}$ Heper, M. (1977) p. 75.
} 
their 'clients'. ${ }^{154}$ So despite remaining professedly reformist, the proletarianised bureaucracy of the 1950s tended to spread an inclination towards nationalist authoritarianism from the administrative elite to a much wider section of Turkish society. ${ }^{155}$

In the absence of an institutionalised ideology legitimising the DP's position as representatives of provincial capitalist development, the economic elite of the centre maintained a value structure similar to the urban bureaucrats' espousal of a return to 1930s Kemalism. Successful industrialists were not the risk-taking, socially mobile innovators characteristic of European development. A study undertaken by Arif Payaslioğlu in 1961, for instance, found that 66.6 per cent of businessmen surveyed came from large-scale agricultural, commercial or industrial backgrounds. ${ }^{156}$ With 14 per cent from market-orientated farming interests (this may be much higher if marital contacts are also included), a pronounced pattern of entrepreneurial investment in land and the commonplace establishment of farmer-owned commercial organisations, these industrialists overlapped heavily with large-scale agricultural interests. ${ }^{157}$ In this sense, the Turkish economic elite were not the developmentalist middle class struggling against old regime, rural feudalism so characteristic of the Western model. Rather than pressing for agrarian reform and a minimum wage for the peasantry in order to expand the internal market, they were, in general, more concerned with maintaining political stability and continuing their profitable relationship with the state. A result of this was that, during the inflationary upheavals and the end of commercial liberalism in the mid-1950s, the government was able to reintroduce greater controls on exchange, as part of a gradual move towards an importsubstitution policy, ${ }^{158}$ and shift its support from the agricultural to the

154 Weiker, W. (1981) p. 34. My parentheses.

155 See Caldwell. L. (1959) pp 123-127.

${ }^{156}$ Cited in Sunar, I. (1974) p. 110.

157 Ibid. pp 117-118.

158 See Öncü, A. (1980) pp 466-467. 
industrial sector without generating high levels of resistance within the integrated economic elite. ${ }^{159}$

To cushion the blow of this change in policy amongst the peasantry (their primary electoral base), as well as to continue countering bureaucratic opposition, the DP sought to acknowledge the continuing political efficacy of Islam. ${ }^{160} \mathrm{~A}$ part of this was the recognition that the secularising reforms of the 1920s and 1930s had penetrated the Anatolian countryside very little - a conclusion also reached by the RPP in the 1940 s. $^{161}$ As such, the government reinstated the call to prayer in Arabic, reopened mystic retreats and the tombs of Sufi 'saints' and established a large-scale religious education programme under the imam-batip schooling system. ${ }^{162}$ When accused, by secularist thinkers, of betraying Kemalist principles, Menderes controversially replied that the government would preserve the reforms that the people had accepted "implying", in Binnaz Toprak's view, "that the rest would be subject to change". ${ }^{163}$ Supported by a large-scale mosque building programme, a considerable rise in the circulation of religious publications and an increase in congregational attendance, "Islamism made important strides, for the first time visibly since the proclamation of the Republic in 1923". ${ }^{164}$ Thus, through what Ümit Cizre-Sakallıoglu describes as "the discovery of the prayer-rug vote", the DP were able to gain considerable credibility amongst traditionalist groups. ${ }^{165}$ Said Nursi, leader of the influential religious order, the Nurcular, for instance, announced his support for the DP during the 1954 general election campaign. ${ }^{166}$ However, the overtly instrumental reasoning behind the government's courtship of the Islamic vote plus "the unflinchingly

159 Reşat Atkan argues that the subsequent decline in agriculture was due to this integrated elite transferring funds from the rural-agricultural sector to their urban industrial interests $(1966$, p. 323).

${ }^{160}$ See Reed, H. (1954) \& (1957) passim.

161 See Stirling, P. (1965) Ch. 12.

162 See Shankland, D. (1999) pp $27 \& 38$.

163 Toprak, B. (1981) pp 78-79.

${ }^{164}$ Landau, J. (1981a) p. 370. His emphasis.

165 Cizre-Sakallığlu, Ü. (1995) p. 756. 
hard stand it took to anti-Atatürk activities of some religious orders [such as the Ticaniya] attest to the claim that the DP would never tolerate the autonomous and self-sustaining development of religious forces". ${ }^{167}$ So while Islam did provide the administration with a votewinning means of appealing directly to the peasantry (and organisationally outflanking the bureaucracy), it was not deployed as a means of political legitimisation. New legislation in July 1953 ensured that religion could not be used for 'political' ends and that secularism remained the dominant paradigm of Turkish administration. ${ }^{168}$

Nonetheless, "there seems to have existed some form of tacit collaboration, based on a community of interests, between the leadership of the Democratic Party and the Nurcular". ${ }^{169}$ For entirely pragmatic reasons, the government promoted what Dankwart Rustow characterises as 'moderate' Islamism, of which elements within Nursi's following were a part. ${ }^{170}$ Presenting government policy as grounded upon liberal freedoms of conscience, Menderes hoped to attract the supporters from each of the two other ideological alignments that Rustow identifies; 'secularism' and 'clericalism'. While this position was useful in maintaining the sympathies of the peasantry, which had been affected little by both the republican state's efforts at secularisation and the rise in urban political Islam, ${ }^{171}$ it was also appealing to traditionalist groups within the entrepreneurial sector who saw "no basic conflict between her [Turkey's] Islamic religion and her membership in the Western family of nations". ${ }^{172}$ Another reason may have been 'moderate' political Islam's partial connection to 'Turkism, or what was termed 'Islamic nationalism'

\footnotetext{
166 See Toprak, B. (1981) pp 83.

${ }^{167}$ Cizre-Sakalloğlu, Ü. (1995) p. 758. My parenthesis.

${ }^{168}$ See Ahmad, F. (1977) pp 368-369.

${ }^{169}$ Landau, J. (1974) p. 185.

170 This section owes much to Rustow, D. (1957) pp 101-107.

171 The Nurcular's primary constituency was the stubbornly traditional eastem provinces. See Cizre-Sakalloğlu, Ü. (1995) p. 767.

172 Rustow, D. (1957) p. 104. My parenthesis.
} 
(İslam milliyetgiliğg). ${ }^{173}$ Some of these activists saw their views as in keeping with the modernist tradition of Gökalp and Akçura and were keen to portray their struggle as within the parameters of Kemalist revolutionary patriotism. ${ }^{174}$ Rustow quotes Halit Ziya Atatuğ speaking in 1951 thus; "Those who helped the nation win the day of salvation [i.e., the Democratic Party landslide] of 14 May 1950, are the religious, patriotic, genuine, pure Turks... loyal to the revolution of Atatürk and to the Muslim religion". ${ }^{175}$ Others, such as Riza Nur (1879-1942) were influential in equating Islamic revivalism with Pan-Turkish sentiments. ${ }^{176}$ In this sense, the DP continued Kemal's use of Turkish nationalism as a means of directing Islamism, outflanking class-based ideologies and providing a statist model of social cohesion. ${ }^{177}$

Although "based on shaky intellectual foundations", 178 Pan-Turkism's emphasis on the mythical, Hittite or Central Asian Turk gained considerable support following the Second World War and the return of Russian expansionism. ${ }^{179}$ Although such a focus did attract some interest from 'moderate' Islamists, it was within secularist networks that Pan-Turkist ideas gained the greatest credence. Competing with the more reform-orientated secular nationalism of RPP affiliated groups, a racist and anti-Semitic press emerged with, according to Bernard Lewis, the apparent support of the Department of Religious Affairs. ${ }^{180}$ Organisations such as The Great East (Büyük Doğu) ${ }^{181}$ put forward chauvinist, anti-socialist and often pro-Nazi opinion embellished with varying amounts of theological rhetoric in what

\footnotetext{
173 Landau, J. (1974) p. 192.

174 The Turkish Hearths (Türk Ocaklar), re-established in 1949, based their ideology on Gökalp's motto of three affiliations; firstly, to the nation, secondly to the ummab and thirdly to contemporary civilisation (see Karpat, K, 1973b, p. 330).

175 Rustow, D. (1957) p. 103. His parenthesis.

176 Associated with the writing of late Ottoman commentators such as Gokalp, this movement sought the unity of all Turkic peoples under a single state (often to be led by the Anatolians). See Landau, J. (1974) pp 193-194.

177 See Cizre-Sakallığlu, Ü. (1992a) p. 143.

178 Keddie, N. (1988) p. 11.

179 See Ağaoğullan, M. (1987) p. 188.

${ }^{180}$ Lewis, B. (1952) p. 44.
} 
Lewis describes as "boulevard fascism with religious colouring matter'. ${ }^{182}$ Numerous other clandestine associations, discussed by Mehmet Ağaoğulları under the heading 'the ultranationalist right', promulgated similar sentiments in publications such as Bozkurt (Grey Wolf - a journal much boosted by a DM5 million gift from Foreign Minister Ribbentrop in $1942 .{ }^{183}$ Although occasionally critical of Kemal as too limited in his geopolitical objectives, ultranationalists generally emphasised the reforms of the 1920s and 30s (particularly etatism, Turkism and pro-Westernism) as a means of broadening their appeal among Islamist 'moderates', the middle classes and elite capitalist networks. The single-party period was depicted as a period of stability when the supposed values of Central Asia, namely "valor, a moral, disciplined, and hierarchical society, obedience, glorification of the leader, and self-sacrifice for the state", had been allowed to flourish. ${ }^{184}$ Hankering after a glorious past established by military conquest, the Rightists viewed the armed forces as not only the key element in the struggle against communism and foreign imperialism, but also as an important political actor. Within the military itself and particularly junior staff officers, ultranationalist sympathies were divided between the Kemalist revivalists such as the Atatürkist Society founded in 1955 and the Pan-Turkist faction of Alparslan Türkeş and others. ${ }^{185}$ The origins and development of these organisations, as well as the more general political objectives adopted by the military during and after this period, will be looked at in the following chapter.

\section{Conclusion}

181 Their criticism of Kemal as oblivious to the wider cause of Turkic peoples led to their disbandment in 1951 and reformation a year later under the name The New Great East (see Reed, H, 1957a, p. 338).

${ }^{182}$ Lewis, B. (1952) p. 44. Mehmet Ağaoğullart suggests that the more extreme PanTurkists "tried to protect themselves from probable official censure by admitting to their associations religious or nationalist right-wingers close to the administration, and joining those founded by them" (1987, p. 190).

183 See Lenczowski, G. (1956) p. 143.

${ }^{184}$ Ağaoğulları, M. (1987) p. 191.

${ }^{185}$ For the former, see Harris, G. (1965) pp 171-172 and the latter, see Landau, J. (1974) pp 222-223. 
To summarise, then, social change in Turkey during this period has been underpinned by a number of fundamental conflicts. A primary ingredient of which was a realignment in class structures. Near the top of the social hierarchy were the large-estate farmers. As descendants of the ayan, they inherited both a tendency to decentralise economic power through connections with exportorientated merchant interests and a strongly state-dependent social position. During the period of Kemalist economic liberalism in the 1920 s, these links, supported by corporatist arrangements between urban industrialists and the government institutionalised during the First World War, were solidified in the pursuit of foreign capital (a process that had significant implications, to be discussed shortly, for the peasant smallholder). Following the 1929 crash, state policy moved away from large-estate farming and towards centralised industrial planning in the manner of the contemporary Soviet Union. As a result, the integrated economic elite shifted capital investment to the manufacturing sector where it made substantial profits, especially following the outbreak of worldwide hostilities in 1939, through an intensive, yet not altogether peaceful, relationship with an increasingly interventionist state bureaucracy.

Within this process there were two seeds of future conflict. The first was the uneven distribution of economic development. The peculiar artificiality of inter-state border delimitation in the south-east of Anatolia, its topography and its intensively localised culture made the Kurdish-speaking provinces particularly resistant to the political infrastructure of the centre. Based on the violent chauvinism of the state bureaucracy, akin to the 'aggressive' nationalism that Mann identifies within contemporary Europe, military approaches to extending centralised control were generally preferred. Large-scale commercial enterprises were also undertaken in the region, but their corporatist, anti-competitive nature prevented the emergence of integrative capital investment. So without a cohesive economic system in which direct 
notions of citizenship could be institutionalised, political and ideological links between the state bureaucracy and the masses were subject to the intermediary influences of the traditional landowner/cleric coalition. This was quite different from the relationship the commercial-state alliance had with the masses in many other parts of the country. There, the state-supported surplus investment and speculation of the economic elite had, as an unplanned corollary, empowered networks of merchant capital which, initially rurally located, had forged links with decentralised urban capitalists enriched by wartime profiteering and strengthened by a rapidly enlarging professional sector. Herein lay the second problem of Turkish elite-led industrialisation. In supporting capitalist development through its integrated cadre, the state was obliged to extend its infra-structural reach (thus decentralising power) unintentionally assisting in the organisation of economic networks opposed to bureaucratic interventionism (particularly structural restraints on competition and international exchange). So rather than a decentralised economic elite establishing developmental patterns inadvertently furthering state centralisation, which Mann points to in Europe, in Turkey it was the consolidation of what Metin Heper calls the 'superstrong state' which, while coalescing with a capitalist elite, inadvertently empowered decentralised economic power networks.

In this sense industrialisation, beginning in the First World War and politically institutionalised in the 1930s and 40s, had extended the powerbase of what could be considered the economic facet of the Turkish 'old regime' from its agricultural ayan roots to urban commercial centres gradually forming an intensive coalition with another old regime faction, the bureaucracy. In a similar way to the European old regime, it adopted democracy as a means of perpetuating its socio-economic position. By 1946, it had become clear that a process of democratisation was inevitable if Turkey was to maintain its favourable geopolitical position. This, in turn, necessitated some kind of land reform as a means of gaining mass 
peasant support. In the tradition of the inkalab, the bureaucracy viewed such a dual approach as a way of maintaining control over the modernisation process. Separated from emergent networks of lowermiddle class capitalism, however, they underestimated the strength of the bourgeois/provincial alliance that emerged in the 1940s. Although the RPP's defeat in the 1950 election did represent a political revolution as old regime governance gave way to an administration more closely connected to provincial elites, there was little associated change in economic power structures. Of the bureaucratic/industrial alliance that made up the centre, it was only the former that suffered a significant diminution in hierarchical position while the economic elite prospered from mechanisation, greater trade liberalisation and an abundance of overseas investment.

The end of the single-party period did not, therefore, represent a revolution based on class, nor did it prompt the instigation of a new political paradigm. Within what Mann calls the 'careerist fraction' of the middle classes, public sector employment predominated. Although the bureaucracy claimed to be neutral and reformist, especially at senior levels, the combination of numerical expansion and declining power both reinforced segmentally-determined differences from the corporate sector and contributed to the overall conservatism of post-war bourgeois development. Although lacking the state bureaucracy's propensity for what Mann terms 'aggressive nationalism', the professional fraction of the middle classes did share a comparable level of exposure to the chauvinism of a statesponsored education. Despite this and their historical connection to the bureaucratic reforms of the 1920s, particularly in relation to the decline of the ulema, the professional classes were generally opposed to etatism as an inefficient method of commercial management. So, while differing in their economic outlook, these two middle-class fractions possessed ideological interests broadly associated with the RPP's blend of secular elitism. The petite bourgeoisie, on the other hand, had received less input from the state and were, in general, 
favourably disposed to neither the restraints of authoritarian interventionism nor the aggressively secularist ideology of officialdom. Nevertheless, because of the contrasting interests of 'moderate' religious traditionalism, sectionally constrained mercantile internationalism and a desire for improved provincial access to the state, they maintained the overall conservatism that Mann ascribes to their European counterparts.

Although some petite bourgeois networks had emerged from the state support of cereal producers during the 1930s, the vast majority of farmers remained non-market-orientated smallholders. With little change in the percentage of the population employed in the agrarian sector between 1927 and 1950, Turkish industrialisation did not significantly increase rural social stratification during this period. The continued presence of the state as the primary buyer of agricultural produce meant that, unlike in Europe, there was not the same organised collusion between private urban capital and the largeestates. The artificially high prices that the government paid for surplus cereal during the 1930 s ensured that the peasantry did not follow the European pattern of proletarianisation. It was not until the beginnings of large-scale urbanisation during the late 1940s that urban working-class networks emerged with sufficient extensiveness to support such a dynamic - by which time small to medium capitalist groups had been reincorporated into a more buoyant market by a return of state patronage. As a result, the decline in the living standards of the peasantry during the Second World War did not give rise to decentralised political networks of a strongly Leftist character. Without extensive economic connections to urban or international markets other than through central officialdom or their agents, rural smallholders focused their disaffection on the RPP bureaucrat rather than corporate capitalism. As Keyder puts it, "instead of a peasantry consolidating its rights on the land against a feudal class as in France, or the emergence of capitalist farming as in England, the revolution in Turkey featured an independent peasantry defending its aspiration to 
a market society against the redistributive policies of a bureaucratic elite". ${ }^{186}$ In all, the greater levels of social space between town and country than Mann identifies as existent in Europe meant that segmental divisions and the traditional centre/periphery cleavage remained much more influential.

Even during the great influx of villagers into Turkey's metropolitan centres during the 1950s, an internally cohesive working-class movement was not forthcoming. Although trade union membership expanded rapidly, workers' leaders failed to secure significant concessions from the administration. Apart from state action and sectional/segmental divides akin to those Mann points to in Europe, three further cross-class cleavages, more or less peculiar to Turkey, prevented a collective sense of group consciousness from emerging within the urban proletariat. The first was the nature of settlement. Chain migration established regionalised, or as some writers have put it 'ruralised', neighbourhoods, particularly within or including gecekondu districts, which tended to act as a locus for traditional social structures and economic networks extraneous to shared class interests. Secondly and associated with this, was the gradual reemergence of a separate Kurdish identity. This, as we shall see in the following chapter, took place not in the south-east of Anatolia, but within the ranks of the urban proletariat and unemployed. Although generally fused to the politics of the left as the ascending Turkish middle-classes came to be identified with the failure of democracy to bring political and economic changes to the vast majority of Kurds, it tended to localise and intensify group affiliations rather than assist in the emergence of an extensively organised class consciousness. Thirdly, the relaxation of Kemal's constraints on religious practice provided a cross-class basis for political organisation that maintained a strong influence on the proletariat in general and economic migrants in particular. In all, these factors mitigated against the emergence of working class unity in Turkey during the 1950s. In all

${ }^{186}$ Keyder, Ç. (1987b) p. 42. 
four areas of Mann's IOTA model they played a divisive role at least partially determining perceived identity, opposition, the social totality and possible alternatives. To conclude then, it is possible to say that the official ideology of the republican state predominated during the political ascendancy of the Turkish middle-classes. While divided between the merits of economic liberalism and etatism, the bourgeoisie were able, until the late 1950s, to restrict political debate to largely within the parameters of Kemalism as both 'moderate' Islamism and Turkish nationalism were deployed to extend support for industrial-capitalist progression. The following chapter will examine the reaction of the old regime, particularly the civil and armed services, and the emergence of polarised ideological groups during the 1970s and 80s. 


\section{Chapter Six: The Military/Industrial Complex}

This chapter looks at the manifestations of Turkish militarism from the 1960 intervention to the early 1990s. Contemporary issues will be dealt with in the next chapter which concludes the thesis. Here, the narrative will outline how the military elite managed the contradictions inherent in their interpretation of Kemalism, how this informed their approach to constitutional politics and the extent to which their role was restrained by civil society. It will examine the different ways in which domestic repression blended with social representation to produce varying regime strategies. These will be compared to other combinations of militarism and social incorporation identified by Mann as features of the polities of the United States and Western Europe. In the case of Turkey, the relationship between such formations, the advance of capitalism and the decline in the military elite's autonomy will also be considered. These will be traced through the 1960s, the military intervention of 1971, the subsequent polarisation and fragmentation of Turkish politics, the 1980 coup and the militarisation of south-east Anatolia.

\section{Militarism}

Mann defines militarism as "an attitude and a set of institutions which regard war and the preparation for war as a normal and desirable social activity".1 While these may, he argues, be organised and directed by less centralised actors, militarism was generally a feature of the state's pursuit of geopolitical objectives or enhanced methods of domestic repression. Since pre-modern infra-structures restricted the state's capacity to reach and coerce its citizens, militarism was, in historical terms, a primary part of foreign policy. From 1130 to 1815, for instance, the English government allocated between 75 and 95 per

1 Mann, M. (1988) p. 124. 
cent of its entire revenue to warfare or military preparation. ${ }^{2}$ Such figures are typical of other European states and, indeed, states in general. That is not to say, however, that there was little variation in their deployment of militarist techniques. Marked differences existed in terms of expenditure and in the overall blend of external and internal coercion states could organise and deploy. During the last two centuries Great Britain, for instance, has combined high levels of international militarism with a comparatively pacific approach to domestic administration. The United States, in contrast, has, despite being relatively secure from foreign aggression, combined slavery and a repressive policy aimed at organised labour with violent coercion towards Native Americans and other minority groups. ${ }^{3}$ So, although broadly comparable in overall military expenditure (allocating an average of 47.2 (GB) and 54.4 (US) per cent of their total yearly budgets to the armed forces between 1820 and 1910), each represented quite different forms of militarism. ${ }^{4}$

Everywhere, though, state militarism was resisted by elements of civil society, particularly liberals and socialists, who sought to limit governmental infra-structures, military budgets, higher taxation, conscription and warfare. While parliamentarians had few successes in restricting geopolitical militarism (foreign policy had long been the prerogative of the monarch), ${ }^{5}$ restraints, of varying degrees of institutional power, upon the state's use of domestic repression did emerge. Mann argues that this tension gave rise to four methods of maintaining public order. ${ }^{6}$ Firstly, as a general alternative to coercion, states could resolve civil disaffection through the use of conciliation, arbitration and persuasion. This was usually supported by a second method, the use of a relatively lightly armed police force organised

2 See ibid., p. 130.

${ }^{3}$ See Mann, M. (1993) p. 86.

4 Ibid. p. 373.

${ }^{5}$ In Italy, for instance, foreign affairs remained a matter for the King well into the twentieth century. In Great Britain, the Foreign Secretary was normally a hereditary peer, second in power only to the Prime Minister and insulated from the Commons by the catchall rubric of 'the national interest' (see Mann, M., 1993, pp 414-415). 
either segmentally (through local landed agents) or centrally. Should disorder be beyond the resources of a constabulary, then paramilitary units could be deployed. If this did not succeed, then state action may escalate to a fourth level, large-scale military repression involving highintensity violence and regular troops. According to Mann, the growth of economic interdependence and the division of labour has led to a decline in the need for centrally organised coercion. Once firmly established, capitalist exchange can generally determine value and property rights without recourse to coercive regulation thereby institutionalising lower levels of domestic repression in comparison to previous modes of production.

The result, Mann suggests, is that capitalist expansion has tended to produce bifurcated structures consisting of "an institutionalised, relatively non-coercive core and an expropriated, militaristic periphery".7 As Western states have advanced, their cores have enlarged from 'home counties' around their capitals to national boundaries before eventually including imperial and then neo-colonial agents all over the world. While not inherently more militaristic than other historical forms of imperial expansion, capitalist enlargement has relied on the institutionalisation of norms that could govern trade values and minimise localised disruption to the production, transportation and exchange of commodities. So in order to be introduced into regions with established and complex property rights, the spread of capitalism has commonly required political support backed up by military force. For Mann this has produced four major effects. ${ }^{8}$ Firstly, technological advances driven by manufacturing have led to ever-more effective weaponry and exponential increases in casualty levels. Secondly, global economic interdependence has greatly enlarged Great Power entanglements leading to the instigation or intensification of conflicts in regions geographically marginal to their strategic interests. Thirdly, capitalism has assisted in the

6 Ibid. p. 403.

${ }^{7}$ Mann, M. (1988) p. 138. 
transformation of militarily valued social qualities from physical prowess, ferocity and cruelty to precision, callousness and impersonal rationality. Fourthly, "the capitalist era has directly implicated not just military personnel but the whole population in its militarism". 9 Although the per capita size of most European armed forces has erratically declined since the seventeenth century and dropped considerably from Classical levels, civilian participation in armaments and militarily-related industries makes the proportion of civil society involved in militarism considerably higher than in previous centuries. Moreover, the modern state's capacity to extract revenues from its subjects means that, as a percentage of overall GDP, twentieth century governments can mobilise far greater resources than their historical counterparts.

Within this macro-process, however, there remained considerable contextual diversity. Domestic militarism did, in fact, blend with the forces of capitalism and social representation in quite different ways. Mann identifies four such variations, namely autocratic militarism, liberalreformist incorporation, capitalist-liberal militarism and semiautboritarian incorporation. ${ }^{10}$ The first was visible in Tsarist Russia and was typified by the widespread denial of citizenship, the vehement repression of workers' groups and the polarisation of class. State elites ran the economy and regularly brought in armed police, paramilitaties and (on almost two thousand occasions between 1895 and 1905) regular troops to enforce strike bans. ${ }^{11}$ Under such conditions and in the absence of any institutionalised system of labour relations, few moderate reform strategies could survive. In response to a uniform system of domestic repression without sectional distinctions, urban working class consciousness "became a totality - aimed at a state that brought a highly centralised and politicised exploitation into almost

${ }^{8}$ Mann, M. (1988) pp 132-136.

${ }^{9}$ Ibid. p. 134.

${ }^{10}$ Mann, M. (1993) pp 682-6

"See ibid. pp 660-666. 
every aspect of life". ${ }^{12}$ As a result, bourgeois democrats were driven underground towards revolutionary socialism and highly statist alternatives. ${ }^{13}$ The second variation, liberal-reformist incorporation, often consisted of systems in which old regimes had involved the middle classes in the organisation of party democracies and then seen "the necessity and even the advantage in compromising sectionally and segmentally with workers" over the institutionalisation of citizenship. ${ }^{14}$ Following the suppression of the Paris Commune in 1870, the French state embarked on such a policy. Domestic militarism became more restrained and the police and judiciary were often used to conciliate rather than coerce. According to Mann this had the dual effect of focusing reformism on the level of the state and factionalising decentralised ideological organisation between "economism, mutualism, social democracy, syndicalism and Marxism... [which] all emerged to compete and conflict, weakening overall working-class cohesion".15

In the third of Mann's ideal-types, capitalist-liberal militarism, citizenship was generally well institutionalised, but accompanied by restrictions on collective civil rights and the selective suppression of labour organisation. Exemplified by state policy in the United States between the Civil War and First World War, ${ }^{16}$ domestic repression took on two forms. The first was the essentially individual nature of property rights which tended to favour employers over organised boycotts, unions, strikes or pickets. The second was the widespread deployment of state militias often reinforced by regular troops. Moreover, for the more extensive and prolonged industrial confrontations private employer paramilitary forces were licensed and given legal powers. As a result, between 500 and 800 American workers died in labour

12 Ibid. p. 662. His emphasis.

${ }^{13}$ See Mann's IOTA model outlined in the previous chapter.

14 Ibid. p. 683.

15 Ibid. p. 669. My parenthesis.

${ }^{16}$ See ibid. pp 644-659. 
disputes between 1872 and $1914 .{ }^{17}$ These high levels of industrial militarism were supported by what Mann calls "a virtually sacred capitalist conception of legality" which, through policing and the judiciary, gave American economic interests almost complete control of the state. ${ }^{18}$ Labour also received little state representation from a party democracy in which issues of domestic repression were handled by the judiciary rather than the politicians. Since the President selects the Cabinet and sets the legislative agenda, both the Republican and the Democrat parties remained factionalised by cross-class, localregional, ethnic-religious segmental coalitions. The United States' federal structure which tended to break-up civil action and focus conflict at a local rather than national level further "fragmented potential class unity". ${ }^{19}$ In all, state action reinforced the inherent divides within American labour preventing the emergence of a perceived totality and potential alternative necessary for the institutionalisation of class consciousness.

The fourth regime strategy, semiautboritarian incorporation, was apparent in Imperial Germany, Austria-Hungary and Japan. It emerged when old regimes successfully absorbed bourgeois calls for greater representation without surrendering to a sovereign party democracy. "Aided by semiparliamentary constitutions that institutionalised segmental divide and rule strategies", ${ }^{20}$ these monarchies succeeded in dominating emergent capitalist interests and remained strongly militarist. In Germany, for instance, Bismarck was able to perpetuate old regime rule despite the introduction of universal male suffrage in 1867.21 By preventing political power networks from developing amongst labour groups (freedom of association was not granted until

\footnotetext{
${ }^{17}$ A figure second only to Russia where between 2,000 and 5,000 workers died. In France it was around 35. Ibid. p. 635.

18 Ibid. p. 647.

19 Ibid. p. 653.

20 Ibid. p. 683.

${ }^{21}$ Mann suggests that this was achieved by using geopolitical competition to distract attention away from the domestic class struggle, by including liberal elements of the bourgeoisie through the introduction of social welfare palliatives and by excluding ethnic minorities and socialists (ibid. pp 671-678).
} 
1908), the German old regime controlled the emergence of a large Social Democratic party. Through this strategy, which G. Roth describes as "negative integration", an electorally successful and fundamentally anti-sympathetic organisation was permitted to exist, but, disassociated from its support base, was prevented "from gaining access to the centres of power". 22 The failure to institutionalise a party democracy, however, led to few restraints on the German military which remained, particularly within its geopolitical functions, largely autonomous from both the German state and civil society. ${ }^{23}$

In terms of domestic repression, however, such high levels of military autonomy were generally more difficult to maintain. An active role for the military in state administration usually "embedded the officer corps in broader political power networks and in dominant economic classes". ${ }^{24}$ This was significantly intensified by the effects of industrialisation. Although mostly recruited from the old regime, the military did absorb significant amounts of capitalist personnel and values during nineteenth and especially the twentieth centuries. This "led them to collaborate with the expanding police and paramilitary institutions of the state" making the dominant economic class much more secure..$^{25}$ Economic links were also developed, sometimes to the extent of institutionalising a 'military-industrial complex', as the high command co-operated with capitalist interests particularly in the areas of weapons production, communications and munitions supplies. In all, by the First World War the military's domestic repression function in many European states can be seen as a complex and often contradictory product of capitalist modernism and old regime interests and values.

Following the end of old regime preponderance in European politics institutionalised at the peace settlement in Paris in 1919, this

22 Roth, G. (1963) p. 8.

${ }^{23}$ See Mann, M. (1993) p. 438.

24 Ibid. p. 439.

25 Ibid. 
combination was reformulated. Notables, the military elite, Churches and royalty were forced "to compromise with the lower classes through parliamentarianism, institutionalised labour relations and land reform". ${ }^{26}$ Under the strain of high proletarian expectations, mass suffrage and weakened state executive powers, the old regime, including the military elite, split into two factions. The first, conservative democrats broadly committed to representational party politics, moved closer to the bourgeoisie-dominated centre. Secondly, authoritarian rightists, predominantly apparent amongst the 'revisionist states' of Hungary, Italy and particularly Germany, advocated anti-democratic constitutions paradoxically claiming to represent 'the people' and established authoritarian, quasi-fascist organisations initially based on post-war paramilitaries. For Mann, the latter eventually institutionalised a new form of modernist nationalist ideology which, in sweeping to power across much of Europe during the 1930s, emerged in place of the industrial-capitalist phase (see previous chapter). Proponents of such extreme rightism argued that liberal, socialist and anarchist internationalism weakened the state making 'true', 'organic' democracy unworkable. Although regional minorities were subject to the same accusations, it was, with the exceptions of Nazi and Japanese concepts of race, voluntary political allegiance rather than ethnicity that determined membership of the nation. ${ }^{27}$

To combat those defined as 'enemies of the people' many advocated extremely high levels of domestic repression. Support for such aggressive nationalism continued to be defined by individuals' relationship with the state. Soldiers, civil servants, blue-collar workers in the public sector, employees of the higher education system and adherents (including some clerics) of the state religion were disproportionately represented in the leadership and more militant membership of such rightist organisations. There was also a

\footnotetext{
${ }^{26}$ Mann, M. (1995) p. 57.

27 "Anyone could", as Mann puts it, "repent and join the nation" (ibid. p. 59).
} 
significant class bias. Although modernist nationalists found support within a broad range of social groups, including the proletariat, their opposition to labour organisation meant that, broadly speaking, "the higher the social class, the more support they got". ${ }^{28}$ In this sense, modernist nationalism, emerging as it did from the collapse of the entrenched control of the masses that the pre-war regimes had enjoyed, represented a rejection of bourgeois-capitalist notions of liberal incorporation (the basis of industrial-capitalist nationalism) in favour of authoritarianism.

In the post-Second World War era, Western European modernist nationalism has been largely neutralised by a gradual process of increased political representation and institutionalised domestic demilitarisation. ${ }^{29}$ Social citizenship, imposed by the Western Allies, has conciliated class relations, albeit "over a narrower band of alternative forms than had existed in the inter-war period", and detached them from the military by shifting the focus of coercive power from its historical dualism of domestic repression/geopolitical competition to the singular function of warfare. ${ }^{30}$ Since capitalism, once established, requires less coercive regulation than previous modes of production, Western European societies have become further demilitarised during the second half of the twentieth century. Since, however, "the absolute level of economic development seemingly required for a transition to democracy has steadily increased throughout the twentieth century", civil citizenship in countries where industrialisation has affected a smaller proportion of society remains limited and military power continues to be directed inwards by the state. ${ }^{31}$ This is particularly so in polities based on what Mann terms 'organic' rather than 'liberal' conceptions of the nationstate. He argues that three features tend to be apparent in such a

\footnotetext{
28 Ibid. p. 58.

29 Though, as Mann notes, it remains "in a more symbolic aggression, requiring few commitments from citizens, directed against hate figures in the less developed world" (1993a p. 120).

${ }^{30} \mathrm{Mann}$, M. (2000) p. 8. See also Giddens, A. (1985) p. 192.

${ }^{31}$ Mann, M. (1999) p. 40. See also Tilly, C. (1990) p. 125.
} 
system. Firstly, the presence of a strong executive, often built by elites on the tradition of monarchic office, which has successfully institutionalised restraints on parliamentary sovereignty. By reducing the power of the legislature, these elites can minimise the decentralising potential of a widely enfranchised citizenry and ensure that an often predominantly rural populace, largely beyond the reach of urban working-class organisation, maintain a statist loyalty in excess of politically liberal levels. Secondly, 'organic' nation-states tend to take an active role in the co-ordination of civil society's economic development commonly favouring centralised planning, corporatist links with big business and large and expensive public sectors. Thirdly, 'organicism' was frequently influenced by the collapse of multi-national empires and subsequent rises in the efficacy of ethnicity as a basis for political mobilisation. Since the state elite is best positioned to speak for the unified, 'organic' people, institutionalised political competition tends not to endure leading to "the exclusion of minority communities and political opponents from full membership in the nation". 32

The following section will look at how these factors have related to the political institutionalisation of capitalist interests in Turkey.

\section{For the People, of the People and by the Military}

Writing in 1967, Colonel Fox of the United States Army observed that in Turkey "consciousness of being a part of the whole nation is greatly strengthened by compulsory military service. The conscript soldier develops a sense of citizenship and a fierce pride in being a Turk". ${ }^{33}$ The basis of this was, and continues to be, Article 35 of the Turkish Armed Services Internal Service Code which states that "the duty of the armed forces is to protect and safeguard Turkish territory and the

\footnotetext{
32 Mann, M. (1999) pp 29-30.
}

${ }^{33}$ Fox, C. (1967) pp 73-74. 
Turkish Republic stipulated by the Constitution". ${ }^{34}$ Although, as one of the 800,000 members of the armed forces, the conscript is thoroughly inculcated with its values, he discovers little about the 35,000-strong officer corps which guides one of the largest and most important institutions in Turkey. As Mehmet Ali Birand puts it, "in no other civilised country in the world is the army so little known and yet so close to hearts of the people". ${ }^{35}$ Nowhere is this civil/military divide more apparent than between elected political leaders and junior officers. Part of the explanation for this, Birand argues, is that training at the military academy is largely focused on how democracy 'should' work and when the newly-graduated officer "discovers the inevitable conditions underlying the realities in the country, he blames the politicians rather than the conditions". ${ }^{36}$

This, combined with the military's autonomy, means that many within the officer corps, particularly amongst junior field ranks, persist in seeing "themselves as continuing the revolutionary vanguard role which they had inherited from the late Ottoman period". ${ }^{37}$ The 'higher' nature of their guardianship position places them above party politics and the relations of production. In this sense, the military in post-war Turkey is quite different from those in other Middle Eastern polities in which, as Manfred Halpern argues, they have been more closely associated with the interests of an emerging capitalist class. ${ }^{38}$ Instead, the Turkish armed forces identify themselves as 'independent' protectors of 'progressive' Kemalist values. ${ }^{39}$ However, since "Kemalism is simultaneously an authoritarian reformism and an aspiration to a Western-style democracy" these values are profoundly contradictory. ${ }^{40}$ The rapid rise of capitalist class power in Turkey during the 1940 s and 1950s has exacerbated this inherent

${ }^{34}$ Quoted by the General Secretariat of the National Security Council (1982) p. 224.

35 Birand, M. (1991) p. xiii.

${ }^{36}$ Ibid. p. 77.

${ }^{37}$ Hale, W. (1990) p. 57.

${ }^{38}$ See Halpern, M. (1963) pp 58-59.

${ }^{39}$ This is perhaps particularly obvious in their ideological affiliation to the West. See Karaosmanoğlu A. (1993) passim. 
irreconcilability. It has forced civil and military bureaucratic elites to compromise with the political expression of this emergent social network. As a result, some have moved towards representational party politics and the emergent bourgeoisie and others, in a similar way to old regime groups in post-1919 Europe, have shifted rightwards favouring quasi-fascist modermist nationalism. This section will examine how, as the divide between democratic and nondemocratic versions of Kemalism widened in the post-war period, the military sacrificed a degree of its political autonomy and moved closer to bourgeois capitalism.

Both the democratic and the authoritarian elements within the Turkish officer corps can be seen in their leadership of the 1960 coup. Following a period of severe decline in the status and remuneration of both the civil and the military bureaucracy during the late 1950s, resentment became focused on the leadership of the DP government. ${ }^{41}$ One faction within the conspirators, led by Colonel Alparslan Türkeş, favoured a prolonged term of military governance, while another, generally consisting of more senior soldiers, preferred a more limited period of rule.42 Although the coup itself followed the chain of command with the more moderate officers predominating, conflict continued within the new military administration. Those that viewed the intervention as an opportunity to embark on an authoritarian programme of social reforms initially faired well. Türkeş was appointed under-secretary to the Chief-of-Staff and new political leader, General Gürsel, and many predicted that, like Nasser from Nagib, he would eventually assume power. He caused considerable alarm, however, in proposing the establishment of a highly centralised 'Culture Super-ministry' outside political influence and absorbing

\footnotetext{
${ }^{40}$ Vaner, S. (1987) p. 238.

41 Two of the leaders of the takeover, Colonels Yurdakuler and Kaplan later commented respectively that the Menderes administration "were leaving the civilised road Ataturk had outlined" through "a policy of greed based on group domination under the guise of economic development". Quoted and translated in Başkut, C., Kemal, Y. \& Güresin, E. (1960). See also Özbudun, E. (1966) pp 15-21.
} 
control of departments responsible for the media, religious affairs and education. ${ }^{43}$ As Walter Weiker notes, "few discerning observers failed to see the seeds of dictatorship" in these measures. ${ }^{44}$ The generals were particularly worried by criticisms from their supporters within the "radical statist-secularist wing of the RPP". 45 The result was that Türkeş and thirteen of his more junior colleagues were dismissed.

Gürsel now pursued a paradoxical policy of appeasing the RPP political activists, the state bureaucracy, the capitalist class and the authoritarian wing of the armed forces who remained aggrieved at both his limited social objectives and the dismissal of the '14'. As a concession to the latter, Menderes was hanged with Foreign Minister Zorlu and Finance Minister Polatkan. ${ }^{46}$ In order to solidify support within the RPP, a State Planning Organisation was established in conjunction with another Five-Year Economic Development Plan. ${ }^{47}$ This was undertaken within a new, more politically liberal constitution designed by Istanbul University and ratified by a popular vote in July 1961.48 Nonetheless, the military retained a considerable amount of power in the new constitutional assembly. As a National Security Council (Milli Güvenlik Kurulu - NSC), they stayed on as permanent members of the Senate and reserved control of the appointment of a further fifteen appointees within the Upper House. ${ }^{49}$ By arranging the political make-up of the subsequent coalition governments and threatening further interventions if their interests were not respected,

42 Sydney Fisher described Türkeş as "a Pan-Turkist and a firm follower of the ideology of Yusuf Akçura" (1963, p. 34). See also Karpat, K. (1970) p. 1666.

${ }^{43}$ See Weiker, W. (1967) p. 133-134.

44 Ibid. p. 134.

${ }^{45}$ Karpat, K. (1988) p. 141.

46 See Ahmad, F. (1977) pp 171-172.

47 Trimberger, E. (1978) p. 132.

${ }^{48} \mathrm{See}$ Ozbudun, E. (1988a) pp 83-84. Samuel Huntington comments that "the army had placed its guns behind the programme of technocrats and ideologues of the RPP in order to increase political participation and mandate more equitable distribution" (1968, p. 232).

49 Doğu Ergil comments that this Chamber was established by "the ruling Turkish military/civilian intelligentsia... to safeguard the democratic institutions created through elite decisions rather than popular action" (1975, p. 144). 
the military continued to take an active part in parliamentary politics throughout the $1960 \mathrm{~s} .{ }^{50}$

Disaffection within the high command persisted, however. Following a failed putsch attempt in February 1962 and another, led by the exiled '14', in May 1963,51 authoritarian elements within the armed forces concentrated on utilising the liberality of the 1961 constitution which had reversed a considerable proportion of the restraints on political association imposed by the DP regime of the late 1950 s. Many became influential in organisations with radically reformist objectives. Of the original 1960 coup leaders, three joined the traditional political home of the state elite, the RPP, two began writing for the Leftist periodical Türk Solu (Turkish Left) and two others joined the socialist group Devrim (Revolution). 52 By June 1965, however, ten others had joined a small, conservative party, The Republican Peasant National Party (Cumburiyetgi Köylü Millet Partisi RPNP). Led by Türkeş, who quickly assumed the chairmanship of the party, these officers set about dislodging incumbent personnel and giving the organisation a "national-socialist bent". 53 Although Türkeş was at pains to deny any Nazi sympathies, "the party's casual interest (at best) in the future of democratic institutions in Turkey, their special attention in fostering youth groups and their arranging paramilitary marches and youth demonstrations, were reminiscent of fascist parties elsewhere". 54

Although in electoral terms the RPNP did not become a major party during the 1960s, three factors served to reinforce anti-leftist sentiments amongst the military and within large-sections of the bourgeoisie thereby pushing both towards the neo-liberalism of the

${ }^{50}$ See Pevsner, L. (1984) p. 34 \& Eroğul, C. (1987) pp 122-129.

${ }^{51}$ See Weiker, W. (1963) passim, Dodd, C. (1979) p. 137 \& Lewis, G. (1976) p. 16.

52 See Vaner, S. (1987) p. 249.

${ }^{53}$ Former Justice Minister Irfan Baran quoted in Ağaoğullan, M. (1987) p. 193.

${ }^{54}$ Landau, J. (1974) p. 210. His parenthesis. Often deploying strongly racist thetoric in an attempt to appeal to Sunni Turks, the NAP had, by the late 1960s, begun to 
official opposition party, the Justice Party (Adalet Partisi - JP). The first was the failure of the RPP-led coalition to reach a satisfactory solution to the crisis in Cyprus. In response to continued attacks on the island's Turkish minority, Prime Minister İnönü threatened to intervene under the conditions of the 1960 Treaty of Zurich. ${ }^{55}$ The refusal of President Johnson to support such a tactic, however, led to the abandonment of already well-advanced military intervention plans in June 1964.56 As a result, Turkey withdrew from NATO's Multilateral Force and pursued closer relations with the Soviet Union including a cultural agreement and a state visit of Foreign Minister Gromyko.57 This caused considerable anger and alarm within the military, particularly from those influenced by Türkeş who was himself a Turkish Cypriot. ${ }^{58}$ It also had a significant effect on the Turkish electorate for, as Abadan notes, "the RPP was constantly attacked during the [1965] electoral campaign for forging dangerous links". 59

These concerns were intensified by a second factor, the plethora of labour groups which emerged quite legally under the 1961 constitution. Of particular importance was the Workers Party of Turkey (Türkiye $\dot{I}_{s} c i$ Partisi - WPT) which grew strongly in the early 1960 s and "was instrumental in advancing the interests of the working class". ${ }^{60}$ Despite the RPP's close surveillance of this group through a revitalised National Intelligence Organisation (Milli Istibbarat Teskilatz - the soon to be infamous MIT), the failure of the civil authorities to restrict the WPT was a growing source of concern for both the high command and the capitalist elite. Under the

interpret Turkish nationalism as "a doctrine of civil war" (Bozarslan, H., 1996, p. 141). See also Yalman, N. (1968) p. 133.

${ }^{55}$ See Eroğul, C. (1987) p. 127.

56 See Evin, A. (1985) pp 129-130. Given that Turkey had received almost $\$ 4$ billion of aid (53 per cent was military items and services) between 1948 and 1962, Johnson's views were difficult to ignore (Shorter, F., 1967, pp 48-49).

${ }^{57}$ See Karpat, K. (1967) p. 166.

${ }^{58}$ For a discussion on how Türkeş exploited the crisis in Cyprus see Landau, J. (1973) p. 284.

${ }^{59}$ Abadan, N. (1966) p. 340. My parenthesis.

${ }^{60}$ Berberoğlu, B. (1982) p. 91 . See also Ecevit, B. (1973) passim. 
leadership of Süleyman Demirel, a former employee of the American Morrison Corporation, the JP (who were benefiting from considerable financial support from the United States) "began to whip up a 'red scare' throughout the country". ${ }^{61}$ This was exacerbated by the WPT's public recognition of the Kurds as a persecuted minority. The military, who had been careful to intern or exile most prominent Kurds as soon as they assumed power in 1960, were especially alarmed.62 The third factor which supported a rise in rightist politics was the rapidity of social change in Turkey during the 1960s. The advent of a televisual mass media, the sudden rise in geographic mobility, the spread of urban, capitalist values, increasing Americanisation and innovations in the built environment were not matched by sustainable economic development. Although consistently high growth rates had enriched and enlarged a significant capitalist class, by 1967 unemployment had reached 11 per cent of the workforce and the average cost of living had risen by 45 per cent since $1960 .{ }^{63}$ For many petite bourgeois groups disadvantaged by the failure of RPP etatism, threatened by changing social values or deskilled by systemic alterations in the economy, "a trustworthy, uncompromising and 'paternalistic' leader" appeared to be a favourable prospect. ${ }^{64}$

So, despite a sharp move towards the political left the RPP was unsurprisingly defeated by the JP in the 1965 general elections. ${ }^{65}$ The return to government of capitalist class interests did not, however, represent an unconditional resumption of civilian rule. The military remained prepared to intervene should the government attempt to

\footnotetext{
${ }^{61}$ Berberoğlu, B. (1982) p. 92.

62 See Entessar, N. (1992) p. 90. Kemal Kirişci writes that during the election campaign of 1963 the WPT's "party leadership organised meetings in eastern parts of the country to raise public consciousness of what it termed the 'eastern and Kurdish reality"' (1998, p. 240). This contrasts with the attitude of General Gürsel who stated, while standing on an American tank in Diyarbakir, "there are no Kurds in this country. Whoever says he is a Kurd, I will spit in his face" (quoted in Muller, M. (1996, p. 177).

${ }^{63}$ Berberoğlu, B. (1982) pp 97-98.

${ }^{64}$ Ağaoğullar, M. (1987) p. 192.

${ }^{65}$ See Landau, J. (1973) p. 266.
} 
implement unacceptable policy decisions. ${ }^{66}$ As a result, the JP maintained the tradition of DP pragmatism and pursued a mixed economy "while displaying the traditional reverence for the army". 67 With the election of General Sunay to presidency in 1966, "an attitude of benevolence bordering on complicity" emerged between the JP leadership and the military. ${ }^{68} \mathrm{~A}$ proportion of the basis for this was the growing tendency for senior military officials to accept executive positions within large corporations upon retirement. In part, such appointments were facilitated by the investment programme of the Army Mutual Assistance Association (Ordu Yardımlasma Kurumu - AMAA). Established in March 1961 to provide social security to military personnel, it had, by 1975 , subsidised 19,000 homes, advanced 35,000 personal loans and amassed assets in excess of two billion Turkish lira. ${ }^{69}$ Since it was managed by the generals themselves, the success of the AMAA in positioning itself at the heart of middle-class consumption, import-subsidising industrialisation and foreign capital exchange led to a significant 'bourgeoisification' of the military elite.

In terms of political expediency, the growing capitalist-military coalition can also be seen as a response to the radicalisation of leftist activism and to continuing divisions within the high command itself. Groups such as the National Democratic Movement (Milli Demokratik Devrim - NDR) and the Federation of Revolutionary Youth in Turkey (Türkiye Deverimci Genclik Federasyonu - Dev Genc), having profited from the growth in trade unionism and in higher education enrolment, ${ }^{70}$ emerged as significant social movements in the late 1960 s. Inspired by

${ }^{66}$ For instance, in 1969 a bill aimed at restoring political rights to former DP members had to be hastily withdrawn in the face of hostility from the military. See Hyland, M. (1970) p. 2.

${ }^{67}$ Karpat, K. (1972a) p. 365. See also Sayan, S. (1971) p. 180.

${ }^{68}$ Vaner, S. (1987) p. 249.

${ }^{69}$ See ibid. pp 251-253.

${ }^{70}$ From 360,285 workers in 1965 to 2,088,219 workers in 1970 (Işikl, A., 1987, p. 316) and from 92,080 students to 149,119 students over the same period (Samim, A., 1987, p. 174, no. 20). There were also great increases in urbanisation. Between 1965 and 1970 all five of Turkey's largest cities grew by more than a quarter (Ankara increased its size by a third) (see Weiker, W., 1972, p. 19). 
the struggle of Guevara in Bolivia and the Viet Cong in Indo-China, the former, in particular, promulgated a Maoist ideology in which loosely associated urban-guerrilla units aimed to destabilise the regime sufficiently to facilitate the takeover of a radical junta from within the armed forces. The result was "a compelling 'fit' between Guevarist concepts of revolutionary immediacy and the tradition of leftKemalism". ${ }^{71}$ With the breakdown in industrial relations and the subsequent increase in strike activity towards the end of the 1960s, the NDR's putative contacts within the officer corps were particularly worrying for the JP/NSC administration. A lack of support from the Confederation of Turkish Trade Unions (Türk-I $\dot{I}_{S}$ ) and the state's deployment of both regular troops and ultranationalist militia to police the strikes, significantly radicalised labour groups and led to the establishment of the Confederation of Revolutionary Trade Unions (Devrimci Issgi Sendikalan Konfederasyonu - DISK) in 1967.72 The following year the number of strikes rose to fifty-four and, by 1970, the figure was 112 including a co-ordinated walkout of over 100,000 workers in Kocaeli and Istanbul. 73 Amid "a general loss of confidence among sections of the bourgeoisie", 74 the high command forced Demirel's government to resign in March 1971.

As well as an attempt to restore the confidence of the capitalist class, this coup can also be seen as a way of pre-empting the activities of the NDR/radical officer conspiracy. ${ }^{75}$ As Semih Vaner notes, such an alliance "bore upon two issues of particular sensitivity: the Kurdish question and the organic integration of the national military apparatus within the Western bloc". ${ }^{76}$ In the tradition of Mahmud Şevket and Mustafa Kemal and following the pattern of the 1960 coup, the general staff and President Sunay acted quickly to protect the chain of

71 Samim, A. (1987) p. 159.

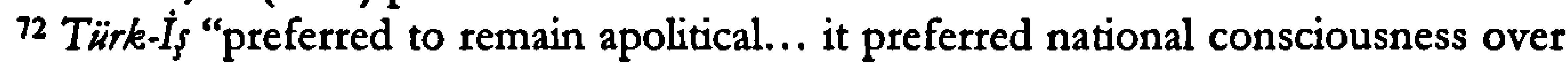
class consciousness and hence over the Turkish Workers Party" (Levy, 1991, pp 142-143). See also Ağaoğullan, M. (1987) p. 192 and Eroğul, C. (1987) p. 135.

${ }^{73}$ Berberoğlu, B. (1982) p. 103.

${ }^{74}$ Barkey, H. (1984) p. 54.

75 See MacKenzie, K. (1974) pp 5-6. 
command from radicalised elements within the officer corps. As a result, three generals and eight colonels were immediately dismissed for "having gone outside the hierarchic mechanism and engaged in political activities basically inconsistent with the disciplinary rules of the armed forces". 77 These measures were reinforced by institutionalising military control over a series of non-party governments between 1971 and 1973 and instigating a number of economic reforms aimed at eliminating the causes of leftist disorder. Most were, however, successfully blocked by the combined opposition of Ecevit (the less pro-military successor of Inönü at the helm of the RPP) and Demirel who were both resentful at the powerful position of the high command's political agents. ${ }^{78}$ Nonetheless, in the case of constitutional amendments, the JP concurred with the military and insisted that the liberality of the 1961 constitution was a luxury Turkey could ill-afford. ${ }^{79}$ As a result, the early 1970s were marked by severe limitations on the freedom of the judiciary, the media, universities and the Assembly Houses. Martial law was declared and, in a series of bloody police and military operations, large numbers of socialists were arrested, silenced or killed.

In many ways the 1971 military reassertion can be seen as a shift in Turkey's socio-economic development. The 1960 coup had brought about a situation comparable to Mann's characterisation of Bismarckian Germany. The politically decentralising effects of a relatively liberal constitution had been considerably allayed by an elite strategy that had absorbed bourgeois calls for greater representation without surrendering to a full party democracy. Through a process of semiauthoritarian incorporation, the military was able to retake its traditional position at the heart of the state elite while not only permitting a return of capitalist rule under Demirel's JP, but also

76 Vaner, S. (1987) p. 253.

77 General Muhsin Batur cited and translated in Hale, W. (1990) p. 70.

78 See Lewis, G. (1976) p. 18.

79 See Ahmad, F. (1977) pp 295-296. 
presiding over a significant growth in the power of left-wing reformism. As with Germany, however, such a policy of 'negative integration' held many perils for continued military autonomy. The combined pressures of capitalist expansion and civil calls for greater political representation politicised the Turkish officer corps, already fractured by the intrinsically contradictory nature of the Kemalist legacy they inherited. So the gradual 'bourgeoisiefication' of the high command, coupled with their age-old imperative of excluding the more radical elements among their subordinates, produced a marked decline in military autonomy and prompted the end of semiauthoritarian incorporation. Purged of its of leftist sentiments, the military elite took on what Mann identifies as the conservativeconstitutionalist / rightist-authoritarian split apparent in Germany.

This, plus the state's clear focus on repressing the left, helped to reinforce and legitimise the political message of the extreme rightwing. ${ }^{80}$ These coalesced around the issue of the presidency as General Sunay's term of office reached an end in 1973. As before, authoritarian Kemalists committed to a prolonged period of political supervision preferred a military candidate whereas a more moderate group argued for an immediate return to complete civilian rule - an option favoured by the main parties. ${ }^{81}$ The result was a compromise in the person of ex-Admiral Fahri Korutürk. Critically, though, this was widely perceived as a defeat for the high command. The effect of this was, as George Harris notes, to create "a fatal disjunction between the real power of the military establishment and the illusion that it could be confronted with impunity by civilian politicians". 82 The combination of a fragmented civil bureaucracy (which, with the RPP's new left-of-centre position, was no longer held together by an institutionalised opposition to socialism), a divided military elite and a wave of nationalist sentiment in the wake of the 1974 Cyprus invasion

\footnotetext{
80 See Landau, J. (1973) p. 287.

${ }^{81}$ See Pevsner, L. (1984) p. 55.

82 Harris, G. (1988) p. 191.
} 
produced rising violence levels on university campuses and an atmosphere highly conducive to Türkeş' quasi-fascist networks. ${ }^{83}$

Table Thirteen: Governance in the 1970 s. ${ }^{84}$

\begin{tabular}{|c|c|c|c|c|c|c|}
\hline $\begin{array}{l}\text { Party } \\
\text { Year } \\
\end{array}$ & $\begin{array}{c}\mathrm{RPP} \\
\% \\
\end{array}$ & $\begin{array}{l}\mathrm{JP} \\
\%\end{array}$ & $\begin{array}{c}\text { NAP } \\
\%\end{array}$ & $\begin{array}{c}\text { NSP } \\
\%\end{array}$ & President & $\begin{array}{c}\text { Prime } \\
\text { Minister }\end{array}$ \\
\hline 1969 & \multirow[t]{4}{*}{27.4} & \multirow[t]{4}{*}{46.5} & \multirow[t]{4}{*}{3.0} & \multirow{4}{*}{$\begin{array}{l}\text { Did } \\
\text { not } \\
\text { stand }\end{array}$} & \multirow[t]{4}{*}{ Sunay } & Demirel \\
\hline 1970 & & & & & & \\
\hline 1971 & & & & & & Erim \\
\hline 1972 & & & & & & Melen \\
\hline 1973 & \multirow[t]{4}{*}{33.3} & \multirow[t]{4}{*}{29.8} & \multirow[t]{4}{*}{$\overline{3.4}$} & \multirow[t]{4}{*}{$\overline{11.8}$} & \multirow[t]{7}{*}{ Korutürk } & Talu \\
\hline 1974 & & & & & & Ecevit/Irmak \\
\hline 1975 & & & & & & Irmak/ \\
\hline 1976 & & & & & & Demirel \\
\hline 1977 & \multirow[t]{3}{*}{41.4} & \multirow[t]{3}{*}{36.9} & \multirow[t]{3}{*}{6.4} & \multirow[t]{3}{*}{8.6} & & \\
\hline 1978 & & & & & & Ecevit \\
\hline 1979 & & & & & & Demirel \\
\hline
\end{tabular}

Indeed, as Table Thirteen shows, the RPNP (which became the National Action Party (Milliyet Hareket Partisi - NAP) in 1969) was gradually able to enlarge its influence during the early $1970 \mathrm{~s}^{85}$ This was also true of Necmettin Erbakan's Islamist National Salvation Party (Milli Selamet Partisi - NSP) who had benefited from the JP government's willingness to utilise Islam in order to garner peasant support during the second half of the $1960 \mathrm{~s} .{ }^{86}$ Using this constituency as a political lever, Erbakan was able to acquire the "legitimisation of an anti-Kemalist party". ${ }^{87}$ By 1973, he had entered government in an unlikely, and extremely volatile, coalition with the ever-more leftward RPP. ${ }^{88}$ Increasingly, though, the NAP were able to draw support

83 Serif Mardin records that 517 students were killed in clashes between violently radical political groups from autumn 1973 to spring 1977 (1978, p. 230).

${ }^{84}$ Source: Ağaoğullan, M. (1987) p. 216 n. 122 and Weiker, W. (1981) p. 145.

${ }^{85}$ See Landau, J. (1982) p. 590.

${ }^{86}$ Enrolment in religious Imam-Hatip schools, for instance, rose from 10,961 in 1965 to 44,275 in 1970 (Landau, J., 1974, p. 176). See also R. Scott's two articles in The Muslim World (1965 \& 1971) and Shankland, D. (1999) p. 88. For an authoritative study of the Party's history, see J. Landau (1976).

${ }^{87}$ Alkan, T. (1984) p. 83. See also Ergüder, Ü. (1988) pp 114-124.

${ }^{88}$ This was particularly apparent following the death of İnönü (the last living link with Kemal) in 1974. Indeed, as Frank Tachau notes, "the leftward shift of the RPP seemed to the military to move the party to an anti-statist stance" (1991, p. 112). 
away from the NSP through the tactical deployment of religious rhetoric concerning Cypriot and Thracian Muslims. ${ }^{89}$ The NAP also proved particularly adept at using the JP's parliamentary fragility to improve its political standing. Despite possessing only three deputies and 3.4 per cent of the vote, Türkeş was appointed Deputy Prime Minister and given control over two key ministries. ${ }^{90}$ Under the newspaper slogan 'Demirel in parliament and Türkeş on the streets', 91 "its armed paramilitary phalange stepped up its acts of violence as the government tolerated, and at times encouraged, them as a defence against the perceived threat from the Left - and especially as a weapon against the RPP".92 This rapidly became self-perpetuating for, as Feroz Ahmad notes, the aim of the NAP's programme of violence "was to emphasise the so-called danger from the Left" and thereby provide for itself "an opportunity to exert a political influence totally out of proportion to its following in the country and its strength in the Assembly". ${ }^{3}$

Superimposed upon the left-right political cleavage were two further divides, Sunnis/Alevis and Turks/Kurds. In focusing on these differences, Türkeş may be regarded as significantly departing from the nationalist discourse of his state sponsors which had always been wary of acknowledging such cleavages. Nevertheless, the growing affiliation between minority groups and left-wing politics continued to provide a role for the NAP's activists. With RPP attempts to reconstruct themselves as a mass socialist party, signified by Ecevit's description of the Alevis as an "oppressed" minority in 1974, the

\footnotetext{
${ }^{89}$ This can be seen in the election results of 1977 where the NSP lost half their 48 deputies compared to an NAP gain of 13 (see Landau, J., 1982, pp 591-592).

90 See Cizre-Sakallıoğlu, U. (1992a) pp 151-152. The NAP was also able to secure virtual control over the Education Ministry through a close affiliation with the rightwing JP deputy Ali Naili Erdem who "appointed their partisans headmasters in all Anatolian secondary schools" (Keyder, C.., 1987b, p. 56). This also served to strengthen the campus activities of its direct action units (see Schick, I. \& Tonak, E., 1987a, p. 369).

${ }^{91}$ Parlamentoda Demirel, Sokakta Türkes (see Ahmad, F., 1977, p. 347).

92 Schick, I. \& Tonak, E. (1987a) p. 369. They go on to claim that the NAP "maintained a persistent policy of infiltration at all levels of government, including the police and armed forces" (ibid.).

${ }^{93}$ Ahmad, F. (1977) p. 347
} 
traditional political 'centre' "remained largely unoccupied". 94 In such an atmosphere, emergent minority consciousness, reformulated by the experience of migration and large-scale social change, took on an increasingly radical tenor. ${ }^{95}$ This was particularly so following the oil price crisis of 1973 (Turkey was importing over 70 per cent of its oil) which made Kurds acutely aware of the fact that only 5 per cent of the $\$ 10$ million (1972) generated from the south-east Anatolian petroleum industry was being spent in that region. ${ }^{96}$ Support also came from the WPT leadership who condemned state policy in Kurdish-speaking areas as one "of assimilation and intimidation which has often become a bloody repression".97 As a result, ostensibly Kurdish groups such as The Road to Freedom (Özgürlïk Yolu) began to identify with the Turkish left's goal of proletarian leadership. ${ }^{98}$ Others rejected such an association and combined a broadly Marxist-Leninist agenda with the overall aim of establishing an ethnically defined independent Kurdish state. ${ }^{99}$ Foremost amongst the latter was the Kurdish Workers' Party (Partiya Karkareni Kürdistan PKK). Founded by Abdullah Öcalan, a former member of Dev Genf, in Ankara in 1974, it became increasingly active as the Turkish political situation deteriorated into chaos during the late 1970 s. $^{100}$

In June of 1977, a year in which there were 758 bomb attacks and 318 deaths (of which the average age was 22), Demirel's coalition lost the general election to the RPP. ${ }^{101}$ Ecevit was able to form a government only in January 1978, however, after a number of JP deputies

\footnotetext{
${ }^{94}$ See Karpat, K. (1988) pp 147-148 and Özbudun, E. (1981a) p. 233.

95 Confrontations between labour-affiliated Alevi groups and broadly NAPsupporting Sunnis, for instance, claimed more than 100 lives in the town of Kahramanmaraş in 1978. See Harris, G. (1980) pp 37-38.

96 See Jafar, M. (1976) pp 67-68.

${ }^{97}$ See Nezan, K. (1980) p. 97.

${ }^{98}$ See Entessat, N. (1992) p. 92.

${ }^{99}$ For more detailed surveys of these groups, see Entessar, N. (1989) p. 94 and Bölükbaş̧i, S. (1991) pp 16-19.

100 Since over 50 per cent of the Turkish middle classes are descended from nonAnatolian refugees who arrived during the turmoil of the nineteenth century, Kurdish nationalism is unlikely to gain widespread public sympathy (Barchard, D., 1985, p. 13). As a result, "the Turkish ruling class is all too aware of the disruptive effect of non-Turkish nationalism" (Hyman, A., 1988, p. 10).
} 
defected. Disastrously, he appeared to support the political left while failing to bring political militias under the control of the state. Kurdish officials were appointed at Cabinet and municipal levels, an historic 'social contract' was signed between the government and Türk-ISs and Ecevit, himself, represented DISK's request to stage a May-Day Rally in 1979 to the security forces. ${ }^{102}$ Seeing that the military would be difficult to dominate politically, he also resisted introducing martial law until a sharp increase in violence towards the end of 1978 forced the Cabinet to act. Apart from Istanbul and Ankara, all nineteen provinces placed under military administration were areas predominantly populated by Kurds. ${ }^{103}$ Allegedly working with rightist groups, and with the assistance of the American Central Intelligence Agency, soldiers and gendarmes, supported by the NAP's partial "colonisation of [the] government bureaucracy", embarked upon a programme of curfews, police operations and extra-judicial detentions aimed at nullifying labour groups and restoring business confidence. ${ }^{104}$

According to Kenneth MacKenzie, the high command was particularly concerned to present the IMF, with whom Ecevit was in the process of negotiating an unprecedented rescue package of $\$ 1.5$ billion, with a democratic and relatively stable front. Indeed, this was part of the reason why the Chief-of-Staff, General Kenan Evren, decided to postpone plans, drawn up in some detail in mid-1979, for a military intervention. ${ }^{105}$ Another reason was the wisdom of awaiting the outcome of the mid-term elections in October 1979. These

${ }^{101}$ Data for 1977 calendar year, see Pevsner, L. (1984) pp 68-69.

102 With declining industrial production ( 5.4 per cent down in 1979), the business community were horrified and organised an anti-RPP advertising campaign. See Cizre-Sakallığlu, Ü. (1992) p. 726 and Boratav, K. \& Türel, O. (1988) p. 38.

${ }^{103}$ See Berberoğlu, B. (1982) p. 119.

104 Schick, I. \& Tonak, E. (1987a) p. 369. My parenthesis. In addition, see J. Chediac's articles in Workers World in January and February 1980. It should also be noted that the NAP's influence within sectors of the civil bureaucracy was somewhat offset by the fact that "throughout the 1970s Alevis gained increasing power both in central government and the municipalities, sometimes beyond their population ratios" (Ayata, A., 1997, p. 67).

${ }^{105}$ MacKenzie, K. (1981) p. 10. 
increased the JP's share of the votes in the Assembly and led to the formation of a minority government under Demirel. The new Deputy Prime Minister, Turgut Özal, devised an implementation plan with the IMF and announced a devaluation of the lira and other structural adjustments to the economy. ${ }^{106}$ This provoked a furore from the RPP who joined with violent left-wing groups in condemning the new administration as a "fascist" regime. ${ }^{107}$ Despite a renewed commitment to the martial law authorities (reminiscent of the JP's approach to the military in the late 1960s), the number of politicallymotivated murders rose from seven or eight a day to twenty during 1980. ${ }^{108}$ The position of the NSP, who controlled a parliamentary vote of twenty, was of particularly concern to the high command. Erbakan refused to support JP anti-insurgency measures to increase the power of the executive, conspicuously failed to sing the national anthem and attended a conference at which his supporters proclaimed "today Iran - tomorrow Turkey". ${ }^{109}$ Within a week of this rally, he, Demeril, Türkeş and Ecevit were under arrest and Evren had declared that the "armed forces have invoked the powers granted to them by the Services Code to protect and look after the Turkish Republic". ${ }^{110}$

In conclusion, the Second Republic can be seen as a process of political realignment between the state and the industrial elite. The capitalist class, which had previously failed to organise extensive power networks within the bureaucratic elite, despite their political representation institutionalised in the 1950s, were, during the JP administration of the 1960s, successful in forging a new relationship with both the civil service, and, most importantly, with the military. By the end of the 1970s, however, the civil authorities had become politically polarised and ineffectual. The growing commitment to pro-

\footnotetext{
${ }^{106}$ See Pevsner, L. (1984) pp 78-79.

${ }^{107}$ See MacKenzie, K. (1981) p. 14.

${ }^{108}$ See Pevsner, L. (1984) p. 80.

${ }^{109}$ See Harris, G. (1988) p. 192.

${ }^{110}$ Quoted in Birand, M. (1987) p. 187.
} 
Western neo-liberalism, strongly anti-leftist ideology and organisational integrity of the armed forces, on the other hand, meant that they, rather than elected officialdom, became regarded as the only viable source of political stability. Furthermore, with the middleground of party politics largely unoccupied for much of the 1970s, the bourgeoisie, in seeking to institutionalise this reformulated blend of capitalism and social representation, had few alternative to the armed forces. The following section will look at how the reconstructed state was organised and the ways in which it sought to reduce the influence, especially within the political centre, of social groups such as socialists, Kurdish separatists and Islamists.

\section{The Militarisation of the Turkish Periphery}

The $12^{\text {th }}$ September coup was a result of two factors. The first was the extremely high levels of civil violence which, in the two years before the takeover, had claimed over 5000 dead and injured nearly 20,000 more. ${ }^{111}$ The second was the inability of the JP to implement the economic austerity measures required by the IMF.112 These elements made it quite different from the 1960 and 1971 interventions. There were, however, similar concerns regarding discipline within the officer corps. While it was clear that the generals favoured the economic approach of the JP, they were also worried that the politicisation of the civil bureaucracy might exacerbate the inherent tensions within their role as guardians of the Kemalist republic. Speaking on September 30th 1980 General Evren expressed these concerns thus: "whenever the army entered into politics it began to lose its discipline and, gradually, it was led into corruption... we had to implement this operation... to save the army from politics and to cleanse it from political dirt". ${ }^{113}$ So a third factor was the generals' desire, based on the tradition of Mahmud Şevket and Mustafa Kemal, to establish a regime which would keep the ever- 
volatile low and middle-ranking officers out of the political arena for good. ${ }^{114}$

Here the civil unrest of the 1970 s provided the high command with a means of busying the authoritarian faction within its ranks. Firstly directed against the left and then, following the PKK's inaugural attack on the army in 1984, at Kurdish political agitation, the provision of an identifiable 'enemy of people' became key to the perpetuation and legitimacy of the military's role in Turkish political life. As a result, the state coercion function was increased over the south-eastern provinces thereby providing a battlefield for modernist nationalism's dogma of civil war. Outside the areas administered by 'emergency rule', domestic repression levels were gradually reduced leading to a polarised and bifurcated system of governance. Geopolitically, the state moved towards a closer affiliation with the West's multilateral military regime supported by a renewed commitment to economic neo-liberalism. In other words, unlike Mann's account of the West's development following the Second World War, Turkish militarism has not moved away from the traditional dualism of warfare and repression towards a single geopolitical function. Within the post-1980 administration's restructured blend of militarism, neo-liberalism and social representation modernist nationalism has endured and prevented the adoption of a more pacific domestic regime.

Top of Evren's agenda following the 1980 coup was neutralising the large numbers of political activists operating throughout the country. To this end, martial law was extended to all regions and, within the first seven months of military rule 122,609 arrests (more than 10,000 in the first week) were made. ${ }^{115}$ By the end of January 1981, 215

${ }^{113}$ Cited in Hale, W. (1988) p. 163.

114 See Ahmad, F. (1981a) passim. An example of this new, tighter control of the coup's forces can be seen in Evren's decision not no allow anyone but himself to discuss politics publicly, see Heper, M. (1987) p. 57.

115 NSC figures quoted in United States Helsinki Watch Committee (1983) p. 10 and The Financial Times September $18^{\text {th }} 1980$. 
people had died, 108 had been sentence to death and, as in the 1971 intervention, many had been tortured. ${ }^{116}$ Newspapers were suspended and general guidelines on 'self censorship' were issued.117 A Higher Education Law was passed by an interim Cabinet led by former admiral Ulusu and dominated by 'retired' staff officers in July $19811^{118}$ which ended universities' political independence and permitted the martial law authorities to sack a great number of 'undesirable' academics. ${ }^{119}$ This was supported by the establishment of a Higher Education Council (Yulesek Ögretim Kurulu - YÖK) in November 1981 which monitored student and staff and ensured that they did not join political parties or engage in 'ideological activities.'120 Other professional groups such as lawyers, doctors, artisans and engineers were similarly restrained. ${ }^{121}$ By September 1981, 167 mass trials, including the leadership of DISK, were underway and by 1983 these had sentenced 39,529 people to jail terms of various length. ${ }^{122}$ Trade unions were banned with the exception of Türk- $\dot{I}_{s}$ who was "prohibited from any form of political activity". ${ }^{123}$ In January 1984 102 WPT members were imprisoned for up to 12 years for "attempting to establish the dictatorship of one class over another". ${ }^{124}$

Similarly punitive measures were taken against members of the civil bureaucracy deemed to be politicised. ${ }^{125}$ In total, nearly 5,000 state employees were dismissed (including 1,700 elected mayors) and a further 18,000 received administrative or penal punishments. ${ }^{126}$ Although numerous rightists were apprehended, including 588

${ }^{116}$ See Cousins, J. (1973) passim \& Berberoğlu, B. (1982) p. 130.

117 This was universally adhered to - especially after one leftist editor was sentenced to seven and a half years imprisonment.

118 See Dodd, C. (1996) p. 133.

${ }^{119}$ See Hale, W. (1982) pp 38-39.

120 These regulations were extremely broad and included instructions on, amongst many other things, the wearing of facial hair. By autumn 1981, three hundred academic had been sacked. See Dodd, C. (1983) pp 48-49.

121 See Pevsner, L. (1984) p. 99.

${ }^{122}$ See Hale, W. (1994) p. 253 and Yeşilada, B. (1988) p. 351.

${ }^{123}$ Yeşilada, B. (1988) p. 353.

124 Quoted in Pevsner, L. (1984) p. 92.

125 The focus of this on left-leaning groups has been particularly detrimental to the Alevi presence within the state bureaucracy (see Ayata, A., 1997, p. 67). 
members of NAP who were charged with inciting 600 murders, leftwing sympathies were perceived by the high command as offering the greatest institutional threat. In all, of the arrests officially acknowledged between September 1980 and February 1983, the government classified 54 per cent as leftists, 25 per cent as unknown, 14 per cent as rightists and 7 per cent as Kurdish separatists. ${ }^{127}$ David McDowall (citing The International League of Human Rights), however, puts the number of Kurds detained much higher at 81,000. By deploying 65 per cent of the second biggest army in NATO in the south-east the military was, he argues, able to force the PKK out of Turkey and into Syrian-protected abeyance. ${ }^{128}$

In order for the military executive to prevent the kinds of particularist political allegiances that polarised Turkish society during the 1970 s, a constitution was brought into force in 1982 which imposed much greater governmental controls on interest group formation and organisation. ${ }^{129}$ Supported by 628 additional pieces of legislation passed into law between 1980 and 1983,130 it generally formalised existent restrictions on voluntary, professional and labour organisation implemented during the immediate aftermath of the coup. As part of a "well corseted framework... for the conduct of political participation by civilians", 131 commercial groups were organised into various chambers more designed to regulate them than

126 Pevsner, L. (1984) p. 93.

127 Ibid. p. $88 \&$ 91. This included the former Minister of Public Works, Serafettin Elçi, who was jailed for two years and three months for stating in an interview that "I am a Kurd. There are Kurds in Turkey" (New York Times, March 27 th, 1981).

128 McDowall, D. (1992) p. 414 \& 420. For the Syrian government, support of the PKK proved a useful bargaining chip in their negotiations with Turkey over the Euphrates water flow which, in 1984, was supplying only 11.3 per cent of her requirements. See Kibaroğlu, A. (1994) p. 143. This became particularly pertinent following the commencement of work on the South East Anatolian Development Project (Güney Doğu Anadolu Projesi - GAP) which proposed to construct twenty-one dams, nineteen hydroelectric power stations and a vast irrigation system. See Kolars, J. \& Mitchell, W. (1991) passim and Van Bruinessen, M. (1988) p. 44.

${ }^{129}$ See Weiker, W. (1987) pp 36-39. In a referendum of November 1982, in which participation was obligatory, the constitution was accepted by 92 per cent of the 95 per cent who voted. The choice, however, was between the constitution and a continuation of military rule. See Pevsner, L. (1984) p. 97.

${ }^{130}$ See Ozbudun, E. (1991) p. 41.

131 Ludington, N. \& Spain, J. (1983) p. 161. 
represent their political interests. ${ }^{132}$ Labour was similarly constrained through legislation which significantly narrowed the definition of legitimate industrial action and provided a mechanism whereby the Cabinet could postpone a strike for sixty days in principal and almost indefinitely in practice. ${ }^{133}$ The constitution also contained considerable implications for non-Turkish minorities:

Article 26 No language prohibited by law shall be used in the expression and dissemination of thought

Article 28 Publications shall not be made in any language prohibited by law

Article 89 No political party may concern itself with the defence, development, or diffusion of any non-Turkish language or culture; nor may they seek to create minorities within our frontiers or to destroy our national unity..$^{134}$

A year later, these constitutional measures were reinforced by legislation which established Turkish as the mother tongue of the country's entire citizenry (as opposed to the official language) and banned the use of all others. It also revised the 1938 penal code which outlawed 'separatist' organisation and dissemination to include explicitly the expression of Kurdish ethnic identity. ${ }^{135}$ In a reintroduction of the discourse of the 1930s, "the constitution also revitalised the Turkish Language and Turkish History institutes". ${ }^{136}$ Amid a considerable increase in state-sponsored ethnographic studies, these promulgated the idea that the Kurds were simply another

\footnotetext{
132 See Heper, M. (1991b) pp 166-167.

133 See Ozbudun, E. (1991) p. 54.

134 See Gunter, M. (1988) p. 399.

135 This was regularly used to prosecute Kurds and even their defence lawyers. See Entessar, N. (1992) p. 96.

${ }^{136}$ Kirişci, K. (1998) p. 242.
} 
branch of Central Asian Turkomen. ${ }^{137}$ In the view of Henri Barkey and Graeme Fuller, the constitution as a whole contained "the most culturally repressive policies of modern times". 138

Figure Five: The Position of the National Security Council in Turkey's State Security Structure. ${ }^{139}$

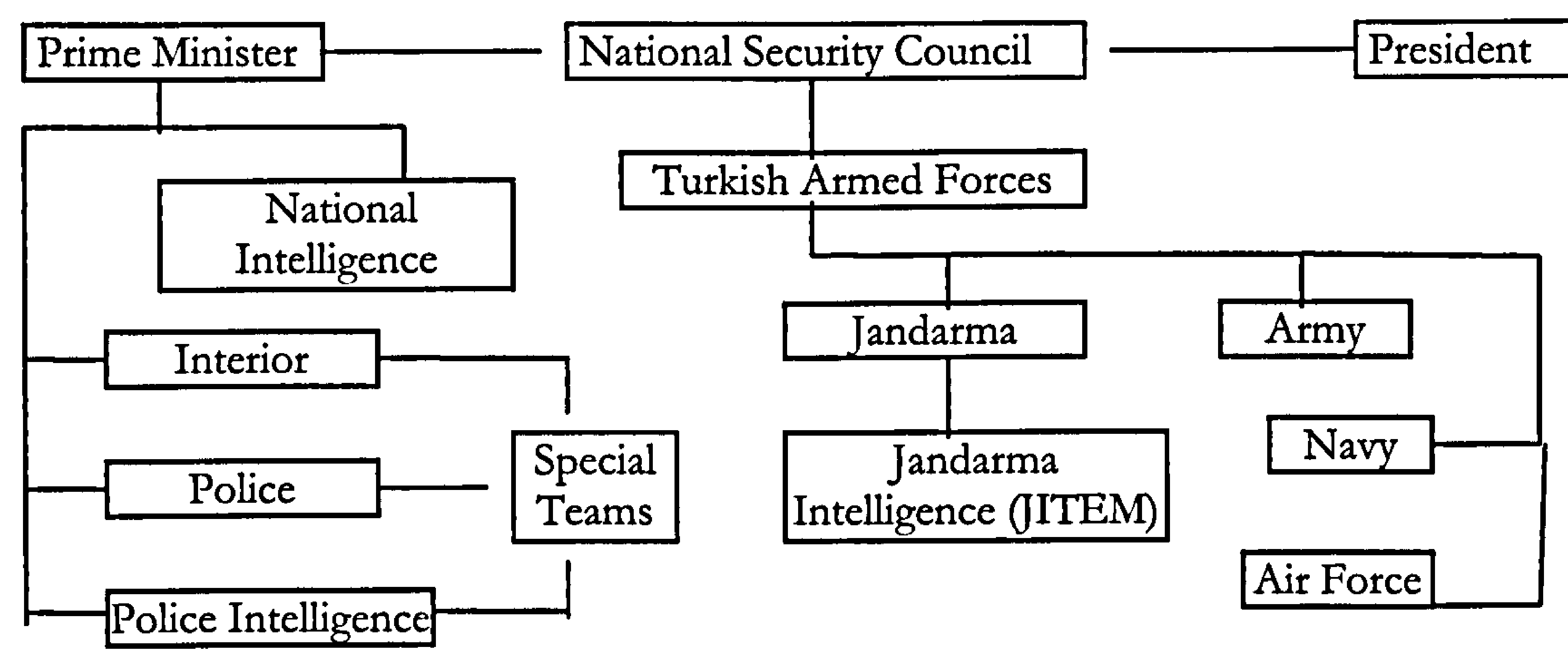

As Figure Five shows, the constitution also solidified the position of the military within the executive. The NSC, chaired by the president, included five members of the general staff and was supported by a new State Supervisory Council to work directly with the chief executive. ${ }^{140}$ For a period of seven years Evren was installed as president and given the right to veto constitutional amendments and appoint constitutional court judges. ${ }^{141}$ Apart from their central role in state security, the high command also controlled military liaison officers in every ministry. The 1961 constitution was amended to abolish the senate and create a single house to which the NSC was not accountable. Furthermore, the military's access to the Cabinet was enhanced under a stipulation which obliged ministers "to give priority

${ }^{137}$ See Izady, M. (1990) p. 35.

${ }^{138}$ Barkey, H. \& Fuller, G. (1997) p. 73. See also Watts, N. (1999) p. 635.

139 Source: The Economist January 31st 1998.

140 The NSC comprised of the Prime Minister, the Ministers of Foreign Affairs, Interior Affairs and National Defence, the Chief of the General staff, the commanders of the army, navy, air force and gendarmerie and the President. See Heper, M. (1990a) p. 307.

141 See McFadden, J. (1985) pp 72-73. 
consideration" to matters put forward by the NSC. ${ }^{142}$ Although ostensibly to be reserved for matters of national security, these were generally interpreted to include "almost all issues which fall under the responsibility of government" 143 thereby institutionalising the NSC as the "highest non-elected decision-making body of the state". ${ }^{144}$

Through a dual approach of pursuing geopolitical legitimacy and institutionalising high levels of domestic repression, it was hoped that Turgut Özal, who was retained as Deputy Prime Minister, would be able to pursue the stabilisation plan devised by him and Demirel undistracted by social unrest and international economic sanctions. ${ }^{145}$ Importation practices were liberalised, a realistic exchange rate policy was adopted, export initiatives were promoted, monetary controls and debt management programmes were put in place, a greater role for the private sector was announced and public spending was rationalised. ${ }^{146}$ Furthermore, with all political parties banned in November 1981 and most organised social groups either excluded from politics or carefully monitored, a highly corporatist arrangement developed between the military state and the capitalist elite. ${ }^{147}$ A key element of this was the need to return to party polices as soon as possible. As Vehbi Koç, one of the wealthiest men in Turkey, warned in a letter to Kenan Evren on October $3^{\text {rd }} 1980$, if there should be any delay in this then "Western countries and their institutions will be suspicious and will not deliver their promises". ${ }^{148}$ In fact, the military elite had been long aware of this possible hazard. ${ }^{149}$ Nine days before

\footnotetext{
142 See Hale, W. (1994) p. 258.

${ }^{143}$ Quoted in Gürbey, G. (1996) p. 13. Since Kurdish attempts at self-realisation have long been regarded as a threat to the 'indivisible unity of the state's people and territory', the NSC remained "the primary decision-maker in the Kurdish issue" (ibid.).

144 Hikmet Ozdemir quoted in Karabelias, G. (1999) p. 135.

145 See Yeşilada, B. (1988) pp 349-350.

146 See Baysan, T. \& Blitzer, C. (1990) pp 10-11 and Wolff, P. (1987) passim. The result of this was, as Korkut Boratav notes, a drop in real wages from an average of $\$ 2.46$ in 1979 to $\$ 1.11$ in $1985(1990$, p. 209). For a broader discussion of the effects of these changes during the 1980s, see Oniş, Z. (1996) passim.

147 See İlkim, S. (1993) p. 193.

148 Quoted in Arat, Y. (1991) p. 142.

${ }^{149}$ See Karaosmanoğlu, A. (1991) pp 172-173.
} 
the coup they had dispatched General Şahinkaya to Washington for high-level talks and in October 1980 Evren received four visits from the NATO Commander General Rogers. These were followed by loans of $\$ 182$ million from the World Bank and other private institutions. 150 In this context, Evren's decision to announce a transition timetable to return to democracy within a few weeks of abolishing party politics (two years before they were actually reestablished) can be seen as an attempt to reassure the West and, with few visible opponents at home, "hardly anything to do with internal demands". 151

Nevertheless, within four months of the ban on political parties being lifted in April 1983, fifteen parties had registered their intention to compete in the November elections. ${ }^{152}$ The NSC vetoed 719 of the prospective parliamentary candidates, however, and reduced the field to only three parties broadly centred on the middle ground of the political spectrum. ${ }^{153}$ Slightly to the left, although deprived of labour and other grass-roots linkages with civil society, was the Populist Party (Halkgf Parti - PP) which gained 30.5 per cent of the vote and 117 seats. ${ }^{154}$ On the right was the Nationalist Democracy Party (Milliyetgi Demokrasi Partisi - NDP) which was led by a retired four-star general and essentially stood on the electoral platform of the 1981 constitution. ${ }^{155}$ It performed poorly in the election, however, and gained only 23.6 per cent and 71 seats. ${ }^{156}$ Between the two was the extremely heterogeneous Motherland Party (Anavatan Partisi - MP). Led by Turgut Özal and consisting mainly of personnel recruited

150 See Paul, J. (1981) p. 4.

151 Dag1, I. (1996) p. 138.

152 See McFadden, J. (1985) p. 74 and Yeşilada, B. (1988) pp 360-361.

153 See Hale, W. (1988) pp 170-173.

154 The PP merged with the Social Democracy Party (Sosyal Demokrasi Partisi SODEP), which had not been allowed to compete, to become the Social Democrat Populist Party (Sosyal Demokrat Halkgt Parti - SDPP) in 1985. See Ayata, A. (1993) p. 43.

155 See McFadden, J. (1985) p. 74.

${ }^{156}$ See Turan, 1. (1994) p. 55. Ergun Ozbudun writes that "this seems to be related to the fact that most voters perceived the NDP to be an extension of military rule" $(1989$, p. 14). 
from the private sector, it maintained a pragmatic, and often paradoxical, approach by developing conciliatory links with the military, with moderate Islamism, with the NAP and, perhaps most importantly, with pro-Western capitalism. ${ }^{157}$ Not closely associated with the parties of the 1970s nor the first choice of the NSC (Özal had, in fact, resigned from the Evren government a year earlier) ${ }^{158}$ and with a broad economy-based appeal, the MP gained 41 per cent of the vote and 211 seats making it the first single-party majority government in Turkey since 1969.159 Indeed, this remained the case until 1991 when the True Path Party (Doğru Yol Partisi - TPP), essentially a reformed JP under Demirel, organised a government in coalition with the SDPP. 160

The MP's victory did not, however, mean the institutionalisation of an entirely civilian administration. "Far form returning to the barracks, the military retained considerable influence over governmental policymaking". ${ }^{161}$ This was most apparent in the areas of higher education (through the central agency YÖK), ${ }^{162}$ foreign affairs and, through their martial law administrators and associated system of military courts, tribunals and prosecutors. ${ }^{163}$ The presence of the military was further reinforced in 1985 with the adoption of a Defence Industry Support Fund (DISF) which was "nearly exempt from Turkish accounting and bidding laws". ${ }^{164}$ Despite the fact that the Defence Ministry budget already exceeded the combined allocations for Education and Health, the DISF, which was initially derived from a 5 per cent levy on income tax, had reached a value of $\$ 1.5$ billion by 1991 . By this time revenue from its investment

\footnotetext{
157 See Ergüder, Ủ. (1991) pp 155-161.

158 In fact, Henri Barkey argues that Ozal was forced out by the pro-import substitution interests of the giant conglomerates of Koç and Sabançi holdings (1990a, p. 184).

${ }^{159}$ See Ergüder, Ü. \& Hofferbert, R. (1987) pp 44-45.

${ }^{160}$ For a discussion of the gradual rise of the TPP, see Cizre-Sakalloğlu, U. (1996) passim.

${ }_{161}$ Evin, A. (1994) p. 25.

162 See Szyliowicz, J (1994) passim.

${ }^{163}$ See Barkey, H. (1990) passim.

164 Günlük-Şenesen, G. (1995) p. 84.
} 
interests had become of central importance. ${ }^{165}$ This had two effects. The first was that it produced a much closer relationship between the military and capitalist elites. The particularly internationalist nature of the defence industry, coupled with the huge wealth accumulated by the AMAA and three other similarly constructed foundations (organised by the Navy, the Air Force and the Combined Land Forces), ${ }^{166}$ have led the military increasingly to regard the private sector, and their representatives in government, "as a major referent with whom they have common interests". ${ }^{167}$ The second was that it helped Turkey to become "the biggest single importer of American military hardware and thus the world's largest arms purchaser... all of which was eventually used on the Kurds". ${ }^{168}$

Table Fourteen: Civilian, PKK and Security Forces Casualties 19841995.169

\begin{tabular}{llcll}
\hline & Civilians & PKK & $\begin{array}{l}\text { Security } \\
\text { Forces }\end{array}$ & Totals \\
\hline $1984-1991$ & 1278 & 1444 & 846 & 3568 \\
$1992-1995$ & 3736 & 10102 & 2775 & 16613 \\
Total & 5014 & 11546 & 3621 & 20181 \\
\hline
\end{tabular}

Such a huge military expenditure programme has underpinned the perpetuation of the army's jurisprudence in south-east Anatolia through which authoritarian elements within the officer corps have retained an active political role unavailable to them in 1960 and 1971. 170 The declaration of a state of emergency in eight provinces in 1987 - two more were added in 1990 - facilitated what Mann terms

165 See Karaosmanoğlu, A. (1993) p. 33.

166 See Karasapan, O. (1987) pp 29-30.

167 Karaosmanoğlu, A. (1993) p. 33.

168 Jonathan Randal quoted in Chomsky, N. (2000) p. 42.

169 Source: Kirişci, K. \& Winrow, G. M. (1997) p. 126.

170 Hakan Yavuz writes that "the blunt and incompetent counter-insurgency tactics of the Kemalist generals have... drained the economy of over $\$ 8$ bn a year" (1998, p. 21). 
'the politics of continuous revolution'.171 In order to maintain the ideological momentum of the 1980 coup and avoid an antithetical 'institutional compromise', the military revived the social engineering and radical reformism of Kemal's celebrated Kurdish campaigns during the Twenties and Thirties. To this end, an extreme programme of Turkification was embarked upon. ${ }^{172}$ The region's print media were heavily circumscribed with only one Kurdish weekly, Walate $M e$, appearing on a regular basis, ${ }^{173}$ the broadcast media were not permitted to schedule Kurdish language programmes and even the lyrics of popular or traditional Kurdish songs were seen as potential vehicles of information for the PKK and banned under the Article 8 of the 1991 Anti-Terror Law. ${ }^{174}$ Within the region's education system, which remains largely staffed by ethnically Turkish personnel, "teachers frequently only attend[ed] to Turkish speakers and apparently ignore[d] Kurdish speakers as unworthy of attention". 175 Through the regional governor's right to "order the temporary or permanent evacuation of villages... [and] the resettlement or unification of inhabitants in such places" in excess of 2000 towns had been emptied and destroyed rendering more than 750,000 people homeless by $1994 .{ }^{176}$ Also by August 1994 around 60,000 men had been recruited into a state-sponsored, anti-PKK militia, the "village guards', which provoked an intense internecine conflict and greatly increased the militarisation of the region. ${ }^{177}$ The results of this

171 See Mann, M. (1997) pp 142-144.

172 This has been compounded by recent trends in military recruitment. Despite the south-east making up 6.3 per cent of the population, it supplied only 1.8 per cent of army cadet intakes between 1982 and 1984. Amongst general staff officers (19841985), though, the figure was 10.6 per cent. See Brown, J. (1989) pp 395-397.

173 Its future is unclear since its editor was sentenced to two years in prison for "instigating hostility in the population" (Kurdish Human Rights Project \& Medico International, 1997, p. 26).

174 This reads "No-one may engage in written and oral propaganda aimed at disrupting the indivisible integrity of the state..." (ibid. p. 10).

175 Kurdish Human Rights Project (1996) p. 9. My parentheses. In response the PKK had, by 1995, murdered more than 150 teachers, forced the closure of 5,210 schools and burnt down a further 192 (Milliyet January 1995)

176 See McDowall, D. (1992) p. 426. My parenthesis.

177 Some traditional leaders prospered greatly from this arrangement. Sadun Seylan, the chief of the Alan tribe in Van, for example, fielded a force of 500 guards for which he received US $\$ 115000$ monthly - in 1989 the PKK murdered his son and two of his cousins. See Jacoby, T. (1998) pp 38-39. 
instability were the displacement of more than three million people (mostly to the highly politicised gecekondu of Turkey's major cities) and, as Table Fourteen shows, the loss of over 20,000 lives. ${ }^{178}$

In Ankara, the MP, in keeping with the contradictory make-up of their membership, pursued a dual policy of promoting a pro-western cultural and economic discourse and attempting to incorporate Islamist sentiments into the state administration. ${ }^{179}$ The latter was broadly supported by the military as "a means of de-politicising society with the aim of combating communist tendencies and undermining the growth of national awareness". 180 Özal, a highranking member of the Naqshbandi Sufi order who once stood for election in Izmir on an NSP ticket, began to attend Friday prayer with his ministers, undertook the $\mathrm{Haj}$, placed other tariga members in charge of the Education and Information Ministries and, in 1990, announced a 237 per cent increase in the budget of the Religious Affairs Ministry. ${ }^{181}$ This was also accompanied, however, by the arrest of 3,000 people for 'anti-secular' activities in 1987, the dismissal of 813 officers and cadets for "having ties with fundamentalist organisations" in 1990 and the institutionalised state invigilation of all Friday sermons. ${ }^{182}$ As such, the "control of Islam became the main vehicle through which the state reshaped modernity in line with the ideology of marketisation while also resolving the problem of legitimacy". ${ }^{183}$ This combination of religiosity and export-orientated economics attracted a significant proportion of the Anatolian petitebourgeoisie some of whom formed a number of pro-Islamic co-

${ }^{178}$ See Kurdish Human Rights Project \& Medico International (1996) passim.

179 The so-called 'Turk-Islam' synthesis. See Szyliowicz, J. (2000) p. 376 and Gençkaya, Ö. (1997) p. 81.

${ }^{180}$ Laizer, S. (1996) p. 101 Although Evren thought that Ozal underestimated the possibility that the Islamic movement might get out of hand. See Heper, M. \& Güney, A. (1996) p. 624.

${ }^{181}$ See Ayata, S. (1996) pp 44-45.

182 See Brown, J. (1988) p. 241 and Ayata, S. (1993) p. 64.

183 Cizre-Sakalloğlu, U. (1996) p. 245. See also Birtek, F. \& Toprak, B. (1993) p. 196. It was also deployed with some effect in the south-east where the military adopted a policy of encouraging young people "to join government directed Hizbullah anti-PKK squads" (Laizer, S., 1996, p103). 
operative firms with considerable success. ${ }^{184}$ The result of this was that, under state tutelage, certain sections of the Islamist movement were able to move from the political periphery to the centre. ${ }^{185}$

The MP was not, however, an entirely ideologically satisfactory home for such interests. As part of a concerted effort by the government to de-bureaucratise its policy implementation structures, large numbers of unelected technocrats were brought in who often operated with the Prime Minister outside Cabinet influence. ${ }^{186}$ Discomfiture over their Thatcherite and anti-populist vision of an economy without redistribution, coupled with the almost unmitigated assumption of cultural globalism, pushed the Islamists towards the xenophobes of the former NAP. ${ }^{187}$ This was compounded by the very high debt dependency on the United States, particularly in military assistance, and the widespread perception that Özal would "do virtually anything in exchange for Western aid". ${ }^{188}$ Furthermore the spectre of further military intervention, continually at Özal's side, helped to ostracise the religious wing of his party. ${ }^{189}$ With the arrival of Mesut Yllmaz, a "convinced secularist", 190 at the helm of the MP following Özal's election to the presidency and his government's decision to support the United States' military action in Iraq in 1990, the position of the Islamists became untenable. Many left to join Erbakan's reformed

184 The biggest of which, MUSIAD (founded in 1990) had, by 1998, over 3000 corporate members representing an annual revenue of $\$ 2.79$ billion. See Narl, $\mathrm{N}$. (1999) pp 3-4 and Öniş, Z. (1997) pp 757-761.

${ }^{185}$ See Göle, N. (1994) and (1997) passim.

${ }^{186}$ See Heper, M. (1990b) p. 610. Like the MP's attempt to control, and benefit from, civil religiosity, these changes in the state bureaucracy can be seen as a means of increasing governmental tutelage. See Kalaycıŏlu, E. (1994) pp 90-91 on Özal's so-called 'decentralisation' initiatives.

${ }^{187}$ For a related, but somewhat different, view see Kadioğlu, A. (1996) pp 189-191 and Tünay, M. (1993) pp 22-23.

188 Ahmad, F. (1988) p. 767. Total grants and loans to Turkey amounted to approximately $\$ 750$ million in 1986 - having peaked at about $\$ 900$ million in 1984 compared to around $\$ 175$ million in 1977 . Of this, the military component was between $\$ 700$ and $\$ 600$ million. See Aricanl, T. (1990) p. 245.

${ }^{189}$ Disagreements between the military and civilian elements of the government were particularly commonplace on issues related to religious expression. Whenever these made it to public attention, they were generally reported within the framework of a possible military intervention. See, for instance, Ahmed Evin's discussion of a 1987 crisis provoked by a report on growing Islamic 'fundamentalism' (1994, p. 31). ${ }^{190}$ See Cornell, S. (1999) p. 213. 
NSP, the Welfare Party (Refab Partisi - WP), which went on to become the largest parliamentary party in the elections of December 1995.191 Following extended negotiations to return to an MP coalition, allegedly ended by the military, Refab was eventually excluded from government by an alliance between the two centreright parties (the MP and the TPP). ${ }^{192}$ The TPP, now under Tansu Çiller's leadership following Demirel's move to the presidency in 1993, contained a number of eminent security officials including a former Chief-of-Staff and the retired head of emergency rule in the south-east. ${ }^{193}$ For this reason, and to prevent a return to an Islamist influence within the MP, the TPP was permitted to form a coalition with Refab following their split with the MP amid a corruption scandal three months later. ${ }^{194}$

Erbakan immediately began to provide the military with a basis from which to undermine the coalition. In October 1996 he appeared on television in Muammar Qadaffi's tent as the Libyan leader accused Turkey of being virtually "under occupation" of NATO and the United States. ${ }^{195} \mathrm{He}$ also negotiated a $\$ 2$ billion agreement with Iran against the wishes of the Pentagon and, in an echo of the events preceding the 1980 coup, invited their ambassador to a rally near Ankara at which the military were accused of "oppressing the people". ${ }^{196}$ The military's response was, as Jeremy Salt notes in a publication for which he was to be dismissed from his post at Bilkent University in Ankara, on the one hand to launch a media campaign associating Islamism with terrorism and, on the other, to ignore the

191 An important part of Refab's electoral base was the south-east. Huri Türsan writes that they were able to "gain the confidence of Kurdish voters who could not vote for the Kurdish Democracy Party" which was forced to withdraw after a stateled campaign of violence (1996, pp 224-225).

192 Comell, S. (1999) pp 211-212.

193 See Pope, N. \& Pope H. (1997) p. 313.

${ }^{194}$ Svante Comell argues that the military additionally hoped that these allegations of corruption, also levelled at Erbakan, would end Refab's "untarnished" image (1999, p. 214).

${ }^{195}$ See Nathan, J. (1997) p. 24.

${ }^{196}$ See Couturier, K. (1996) p. A31 and Kalaycıoğlu, E. (1997) p. 8. 
government wherever possible. "Over Erbakan's head", 197 the high command consolidated its relationship with Israel through a series of politically unauthorised visits and launched an anti-PKK incursion into northern Iraq of an unprecedented scale without informing the prime minister. ${ }^{198}$ Having announced in February 1997 that Islamism had become a greater threat to the republic than the PKK, ${ }^{199}$ the military appealed to the Constitutional Court to censure Refab on the grounds that the party had infringed the secular basis of Turkish state. This led to Erbakan's resignation in June, the closure of Refab the following January, the exclusion of the party leadership from organised politics for five years, innumerable arrests and the dismissal of over two hundred officials. As a result, "the military was able to enhance its autonomy to the point where it was able to form an investigative body, the Western Study Group, that is not legally accountable... [and whose aim] is to collect evidence on fundamentalists and other 'public enemies"'. ${ }^{200}$

Since the return of the military in 1960, and especially from 1980 onwards, Turkey has taken on the characteristics of what T. L. Karl identifies (in his study of El Salvador) as a system of imposed electoralism'.201 This combines representative institutions and mechanisms with high levels of domestic repression, often selectively deployed against certain out-groups, and limits on legislative power. Given the corporatist nature of Turkish politics, such a brand of 'democracy' has proven well suited to both the military and the capitalist elite. In this sense, the post-1980 era marks a departure from earlier periods. Rather than being restrained by the perpetual threat of military intervention, political liberalisation became appropriated by

197 Salt, J. (1999) p. 75.

198 See Jenkins, G. (1997) p. 5.

${ }^{199}$ The Commander of Naval Forces speaking in Miliyet February $25^{\text {th }} 1997$.

200 Çandar, C. (1999) pp 131-132. My parenthesis. This was to complement the high command's virtually unfettered control over MITT whose extra-judicial violence (occasionally in collusion with Mossad) and criminality (which the notorious Susurluk incident reveals) had reached new heights. See The Economist January $31^{\text {st }}$ 1998 and The Independent January $24^{\text {th }} 1998$.

${ }^{201}$ Karl, T. (1986) p. 35. 
the military. The imperatives of territorial and ideological integrity, apparently so threatened by the associated forces of Islamism and Kurdish/leftist insurgency, legitimated the high command's control over processes of social change. As Mark Muller points out, "since national security is equated with national unity, and national unity with Kemalist ideology, all political opposition to this ideology, in practice, falls within the ambit of this jurisdiction... [making the military] the arbiters of what constitutes legitimate political consent". ${ }^{202}$ The dual nature of this ideology combined with the effects of industrial development has, in a reflection of the bifurcated structure Mann identifies as inherent to capitalist expansion, led to a twofold application of state repression. The south-eastern provinces have provided both an outlet for the authoritarian reformist wing of the military and, with the associated 'evils' of Islamism and leftism, a means of legitimisation for the high command who, in true janissary tradition, have successfully prevented such peripheral forces from entering the core.

\section{Conclusion}

During this period the military has been able to secure an increasing amount of political power in Turkey. What emerged was an unstable amalgamation of three forms of regime strategy. Following the 1960 intervention, the military elite established a blend of domestic repression and social representation broadly comparable to Mann's ideal-type of semi-authoritarian incorporation. Initially conceived as a return to power of the traditional state elite, the takeover was born of sentiments broadly unsympathetic to the rising levels of political expression afforded to the emerging capitalist class. In an echo of Bismarck's strategy of 'negative integration', the 1961 constitution aimed to permit the existence of extensive networks of decentralised social organisation without allowing them access to the political centre. As in imperial Germany, geopolitical issues (Cyprus and

202 Muller, M. (1996) pp 177-178. My parenthesis. 
NATO) were deployed to distract attention from the domestic class struggle, social palliatives were introduced to incorporate bourgeois liberalism and socialists were vigorously repressed. Similarly, a key feature of this strategy was the existence of a powerful and highly autonomous military cadre within the state elite.

As Mann points out, however, the durability of such autonomy within the military's domestic repression function tends to be limited. PostWorld War Two industrialisation had produced greater social mobility, outlined in the previous chapter, and reduced the status of traditional roles, such as the armed forces, in favour of politically ascendant professional and mercantile associations. The RPP's movement leftwards and the JP's victory in the 1965 election provided an opportunity for the military elite to recruit a sympathetic referent group within these groups. Beneath the generals' gradual movement towards bourgeois capitalist affiliation with Demirel, however, the armed forces remained divided. Some senior officers found authoritarian expression in Maoist organisations and others in the modernist nationalism of the NAP. This and the more fundamental disjunction between constitutional and anti-democratic versions of Kemalism can be seen in the generals' reluctance to take a more prolonged interest in government following the 1970 intervention. Instead, they preferred to support covertly the activities of the NAP as a means of repressing decentralised left-wing groups. Nonetheless, once it became clear that these fractures threatened the traditional home of old regime power - their international economic linkages military intervention was inevitable.

Here, however, the perennial problem of how to keep the radical officers out of power appeared. Mahmud Şevket had found a partial solution in the First World War, Kemal in the War of Independence and Gürsel and Sunay in pre-emptive purges. Now, though, domestic and geopolitical conditions precluded both internal expulsions and external adventures. Group unity, first inside the armed forces then 
within society as a whole, was to be established through the identification of an endogenous foe. For this reason, a bifurcated blend of social representation and domestic repression was institutionalised in Turkey during the 1980s. Outside the south-east, the policing of civil society did not, for the most part, escalate beyond the deployment of civilian forces. Within areas affected by Kurdish insurgency, however, regular troops were the backbone of the state's attempts to protect order and property. Coercive reforms such as the village clearance programme, the organisation of the village guard system and the close supervision of all expressions of non-Turkish identity were instigated with neither civilian input nor monitoring. In this way, the institutionalisation of a small oligarchy of military commanders in the south-east following the 1980 coup, unhindered by political restraints, provided a role for the authoritarian wing of the officer corps which had been lacking in the interventions of 1960 and 1971. In other words, in establishing an 'enemy of the people' who were prepared to engage the state violently, Kurdish activism offered modermist nationalists within Turkey an opponent for their dogma of civil war who were politically, ethnically and culturally identifiable.

Consequently elements of capitalist-liberal and autocratic militarism were blended with the semiautboritarian incorporation of the 1960s. While the 1982 constitution institutionalised workers' rights, collective organisation remained extremely difficult to effect. Throughout Turkey the continuing influence of the military elite within civil politics, coupled with the very broad interpretation of what constituted a matter relating to national security, meant that the nominally independent judiciary could be deployed by the state to promote the interests of property and capital. In a manner comparable to the ways in which the United States controlled labour opposition to large-scale economic changes between the American Civil War and the First World War, these injunctions were particularly targeted at socialists and attempts to organise large-scale unions. In response, labour could do little. Since democratic party politics in 
both the Turkish and the American assemblies were dominated by cross-class, local-regional and ethnic-religious coalitions, representatives of the proletariat were few. Although the presence of an semi-autonomous and permanent military cadre within the government ensured that the capitalist class did not entirely control domestic repression levels in the same way that Mann identifies as a feature of American social organisation, the gradual 'bourgeoisification' of the general staff led to a considerable overlap in the two groups' interests. The military's investments and corporate position, both within the defence industry and in the private sector, and the DISF-led increases in state extraction generally furnished the high command with similar anti-labour incentives as the capitalist elite.

This relationship between domestic repression and social representation in the south eastern provinces was more indicative of Mann's ideal-type, autocratic militarism. As in Tsarist Russia, state, and state-affiliated, elites ran the economy. These "responded to unions, strikes, and socialist parties as they did to all such manifestations of collective organisation. All were banned as a threat to public order". ${ }^{203}$ Unlike the Russian imperial state, however, military governors in the ten provinces covered by emergency legislation adopted strategies which incorporated certain elements within the social hierarchy they governed. These were pursued both through military recruitment incentives to combat the PKK and through economic development packages administered through GAP. By developing the village guard system the Turkish state was able to utilise traditional civil power structures to fracturing Kurdish allegiances and prevent the emergence of extensively-held notions of class consciousness. ${ }^{204}$ It also sufficiently polarised Kurdish opinion to obviate the possibility of moderate civil response strategies. Amid high levels of internecine violence, the state's policy in the south-east

\footnotetext{
${ }^{203}$ Mann, M. (1993) pp 661-662.

${ }^{204}$ See Mann's IOTA model discussed in the previous chapter.
} 
can be seen as an extension of Kemal's methods of institutionalising state links with a coterie of traditional leaders aimed at maintaining peripheral segmentalisation. This has served to hinder the spread of decentralised capitalist exchange thereby impeding the emergence of extensively-held notions of popular sovereignty within the south-east. 


\section{Conclusion}

To conclude, this chapter will look at three inter-related areas. Firstly, Mann's framework of social power will be reconsidered. His system of four organisational networks will be traced over the Ottoman/Turkish pattern of change with particular reference to the different institutional attributes of each. The ways in which he accounts for the emergence of state centralisation will also be considered in relation to his five-phase account of nationalism. Secondly, key aspects of Mann's historiography will be compared to the account of Turkish social development presented in the preceding four chapters. This will aim to highlight deficiencies and strengths within Mann's narrative and to present the Turkish trajectory as a complement or counterpoint to his analysis of large-scale historical change in Europe. Finally, the concluding section of this chapter will comment on methodological issues pertinent to both this thesis and Mann's account of the past. It will also position this work within the tradition of historical sociology and re-examine the scholarly debate which surrounds the discipline as a whole.

\section{Power Structures}

This thesis has followed Mann's account of social power and combined both the 'predatory' view of governance, as in Levi's analysis, and the collaborative system which Skocpol and others have emphasised. For instance, only at its most intensive and logistically narrow, can military power be organised without institutional reference to the ruled. In order to ensure compliance over a more extensive population, collaboration with local elites - apparent from Sargon's temple legislatures to the Turkish state's village guard system - has been imperative. Economically, too, maintaining control over the means of production has consistently necessitated devolving a degree of organisational power to institutionalise specialised functions 
essential in the perpetuation of an elite's supervisory position. Similarly, ideological power can either be used collectively to reinforce extensive social identities by institutionalising a belief structure which transcends existing organisational forms or immanently to intensify the distributive power of an established elite. The state, as the primary organisational form of political power, also represents, on the one hand, a collective means of attaining extensively-held social goals and, on the other, a potential vehicle for elite domination. In this sense, states tend to act in a combination of two ways. Firstly, they attempt to extend their infra-structural power by institutionalising essentially collaborative linkages with civil groups. Secondly, they wield distributive forms of despotic power without reference to non-state actors. Since the emergence of statehood in Akkadian Mesopotamia, these two dimensions have combined in different ways to produce imperial, feudal, democratic and authoritarian forms of governance.

Figure Six: Large Scale Change in the Development of the Ottoman/Turkish State (emboldened text represents the predominant power source of the period).

\begin{tabular}{l|c|c|c|c}
$\begin{array}{l}\text { Power source } \\
\text { Social change }\end{array}$ & Politics & Ideological & Economic & Military \\
\hline $\begin{array}{l}\text { Ottoman } \\
\text { Change }\end{array}$ & $\begin{array}{c}\text { Decreasing } \\
\text { Elite Unity }\end{array}$ & Proto-Nationalism & $\begin{array}{c}\text { Rising Market } \\
\text { Forces }\end{array}$ & $\begin{array}{c}\text { Increasingly } \\
\text { Decentralised }\end{array}$ \\
\hline $\begin{array}{l}\text { The End of } \\
\text { Empire }\end{array}$ & $\begin{array}{c}\text { Bureaucratic } \\
\text { Ascendancy }\end{array}$ & $\begin{array}{c}\text { Secular Nationalism } \\
\text { vs Theocracy }\end{array}$ & $\begin{array}{c}\text { Corporatist } \\
\text { Capitalism }\end{array}$ & $\begin{array}{c}\text { Defensive } \\
\text { Modernisation }\end{array}$ \\
\hline $\begin{array}{l}\text { Multi-Party } \\
\text { Politics }\end{array}$ & $\begin{array}{c}\text { Bureaucratic } \\
\text { Decline }\end{array}$ & $\begin{array}{c}\text { Industrial-Capitalist } \\
\text { Nationalism }\end{array}$ & $\begin{array}{c}\text { Elite } \\
\text { Integration }\end{array}$ & Decline \\
\hline $\begin{array}{l}\text { The Rise of } \\
\text { the Military }\end{array}$ & $\begin{array}{c}\text { Bifurcated dom- } \\
\text { estic repression }\end{array}$ & Modernist Nationalism & $\begin{array}{c}\text { Bourgeois } \\
\text { Capitalism }\end{array}$ & $\begin{array}{c}\text { Military-Industrial } \\
\text { Complex }\end{array}$
\end{tabular}

The primary motor of such historical dynamics is the ways in which the four sources of power have inter-related. Throughout the past, certain organisational networks, or combinations of networks, have been more influential in this struggle for power than others. Mann is correct in identifying political power as the fundamental organisational source in the establishment and maintenance of 
imperial governance. The tension between centralising and decentralising forces was the predominant power structure during the period of imperial state development which culminated in the infrastructural extensiveness of the western Roman empire. As Figure One shows, the Ottoman empire was no exception. It, too, was largely defined by a fundamentally political divide between the askeri and the reaya which prevented civil groups from organising sufficient power resources to challenge its economic, military and ideological hegemony. As in Rome, the political position of the Ottoman imperial state was eventually challenged by highly extensive ideological networks of power leading to a decline in elite unity. In Mann's study of western Europe, these provided, in the form of the Christian Church, sufficient normative pacification to re-cohere feudal elites and to form the basis for an intensification of the declining empire's trading networks. In the eastern Mediterranean region, a combination of imperial contraction and colonial encroachment strengthened peripheral elites and ended the rigidity of the askeri/reaya axis. As a result, contention along ideological lines, particularly between the forces of proto-nationalism and theocratic traditionalism, began to predominate over other power networks.

In both regions, such decentralised ideological networks were gradually absorbed by non-religious modes of social explication as emergent capitalism began to gain significant levels of extensiveness during the late medieval period. Mann argues that, in Europe, this economic preponderance had, by the late eighteenth century, been instrumental in empowering and infra-structurally organising the modern nation-state. Much later, in Turkey during the inter-war years of the twentieth century, an integrated elite of industrialists and largeestate farmers institutionalised close ties with the state bureaucracy, around which there coalesced an extensive, albeit regionally varied, penumbra of capitalist groups. From this basis, a reordering emerged from the Second World War which marked the beginning of a period of economic power contention as bourgeois interests challenged the 
ideologically-legitimised administration. In Europe, Mann outlines a period of comparable middle-class ascendancy which he identifies as the locus for resistance to the rising power of military organisational networks during the nineteenth and twentieth centuries. While the Turkish bourgeoisie did not become the basis of popular sovereignty with anything like the extensiveness of the European middle-classes, they did attempt to reduce the political power of the military high command. Eventually, though, capitalist and military elite interests conflated. This marked the beginning of a period of power contention between the state, as representatives of 'the people', and various 'internal enemies' which kept Turkish militarism away from the European focus on geopolitics and concentrated on organisational networks primarily aimed at domestic repression.

\section{The Politics of Empire}

As outlined in Chapters One and Two, the autonomy and power of a state, as the primary organisational form of political power in society, derives from the centralised regulation of social relations. As empires coalesced and expanded, he argues, alternative bases for social order such as force, custom and exchange - could not govern social interaction as efficiently as an organised and centralised administration. Although the pattern of imperial development within these power networks makes up much of the first volume of The Sources of Social Power, Mann makes no mention of the Ottoman state. Neither is there a discussion of the ways in which the Eastern Roman Empire differed in its organisation of political power from the essentially unilinear account of western European development which Mann presents. As a result, Mann's narrative loses some of its comparative breadth and explanatory power.

This is particularly apparent in Mann's treatment of imperial levels of infra-structural power. $\mathrm{He}$ is mistaken to claim that the Western Roman Empire possessed "about as high a level of intensity of 
territorial control as could be attained within the logistical constraints imposed on all agrarian societies". In contrast to Rome's reliance on a universal ruling class, the Ottoman system of governance, as outlined in Chapter Three, eliminated the need for an intermediary, and potentially decentralising, social stratum. In contrast to Mann's analysis of Rome, where a "three-way power stand-off" between the state, an economically decentralised ruling class and the people prevailed, the Ottoman state maintained sufficient levels of infrastructural reach to prevent local elites from organising extensive, and thus potentially challenging, networks of power. Moreover, through the strict enforcement of a meritocratic system of appointments and promotion, the use of summary dismissals/transferrals, the seizure of private property and prohibitions on the inheritance of position or wealth, the capacity of state agents to decentralise power was also heavily circumscribed. Furthermore, within the non-clerical branches of the askeri, the widespread use of prisoners-of-war and indentured provincial recruits, many of whom were also prohibited from marrying until retirement, meant that they were, by and large, kept separate from social networks in civil society and from the masses in general. The result was that, unlike in Rome, the Ottoman state was not obliged to delegate authoritative power in order to rule. So instead of the multiple and cross-cutting social cleavages that developed in Western Europe, the Ottoman Empire, continued to be defined by a primary axis dividing the state from all social strata.

This is not to say, however, that the Ottoman empire was not subject to constraints similar to those Mann identifies as a feature of other pre-modern systems. The fundamental problem for expanding states is that, as the number of their citizens increases, both the variety of actions which they can be compelled to undertake and the degree to which they can be coerced decreases. In other words, as power extensiveness grows, its comprehensiveness and intensity diminishes. In accordance with the arguments presented in Chapter One, this is

${ }^{1}$ Mann, M. (1986) p. 250. 
for three main reasons. Supervision becomes more difficult, decentralised challenges increase and the character of power-subjects diversify. In this sense, empires such as Rome and the Ottomans became victims of their own successful enlargement. According to Mann, Rome attempted to offset these perennial problems by empowering a gigantic common market which integrated a senatorial elite through which it ruled. The Ottomans, in contrast, governed through the greater infra-structural reach of an extensive and cohesive system of state agents. Both states were, however, unable to deal effectively with territorial stagnation which tended to undermine their capacity to organise political change. In this sense, Mann's elucidation of Roman political change offers a useful counterpoint to the greater infra-structural reach and political centrality of the Ottoman empire. Comparing the two systems helps to explain why western Europe eventually became dominated by a decentralised class of feudatories while the Turkish republic continued to be defined by a rigid state/subject divide.

Similarly, Mann's account of the very early signs of what he calls 'national crystallisation' also provides a fruitful means of examining late Ottoman political change. Of the five nationalist phases he identifies, the first two - religious and commercial-statist - are termed 'proto' or pre-modern stages. The former initially emerged as a form of collective identity based on the Western Church's relationship with the European monarchies in the wake of the Roman collapse. Mann argues that the Roman senatorial classes were able to use the pacifying effects of the spread of Christianity to solidify their position in the post-imperial ecumenical order which emerged in western Europe. These decentralised and legally protected economic linkages eventually merged with the authoritative structures of the Papacy to organise power networks that were of sufficient extensiveness to form a basis for nascent notions of a 'national' collective identity. The Ottoman polity, in contrast, was structured around a complex array of peripheral cleavages aimed at maintaining a segmentalised class 
structure fundamentally divided by both religious affiliation and a centrally-controlled system of status allocation. This largely restricted collective perceptions of group identity to non-Muslim minority groups (millets) and inhibited the development of extensive 'religious' proto-nationalist sentiments.

Indeed, the empowerment of the Ottoman ulema meant that the limited forms of religious proto-nationalism that did emerge within the Muslim majority were much more multi-ethnic and universalist in character than in Europe. The clerics' role in connecting the masses to the global ummab through the traditional office of the Caliph, which guaranteed the looseness of the bond between the state and periphery, ensured that less centralised ideological networks remained localised and intensive. This emphasis on flexibility and diversity maintained a vertical loyalty to the centre quite unlike Mann's account of the horizontal homogeneity of Roman cultural expansion. The Ottoman state made few efforts to promote the diffusion of cultural ties to, and within, the periphery. Instead, a rarefied state vernacular, unintelligible to all but the higher echelons of officialdom, was maintained which excluded peripheral elites from the politics of the centre and prevented the organisation of decentralised power networks comparable to those within Rorme's ruling class culture. Reinforced by the verticality of state agency, this ensured that no extensive, and therefore potentially decentralising, perceptions of group identity took hold within the masses. As a result, the emergence of proto-nationalism in the Ottoman empire could not follow the same pattern as in Europe.

Another reason for this was that, although the Christian Church shared the extensiveness of the ulema, it was more vulnerable to politicisation and thus less cohesive. As a result, the emergence of scientific rationalism tended to limit the clerics' exegetic legitimacy. The eventual effect was to exclude the Church from the political power networks of the centre which were, instead, utilised by secular 
authorities to increase their infra-structural capacity to reach, and therefore tax, their citizens. Ultimately, this gave rise to a system of feudatories and monarchs which began to curtail the extensiveness of the relationship with the masses thereby institutionalising the beginnings of, what Mann terms, 'commercial-statist' protonationalism. Within the Ottoman empire, however, the state had few organisational linkages with the masses outside the theocracy. The ulema's highly immanent role in transmitting messages from the centre to the periphery, combined with their well-entrenched tradition of political autonomy, meant that they were less susceptible to protonationalist absorption. The Ottoman state, with its rarefied position and intra-elite language, could neither dominate the ulema nor use it to increase its centralised control of civil society and thus it could not follow the European model of displacing peripheral identities in favour of more extensive notions of group consciousness. In all, rather than non-religious forces gradually absorbing ecumenical networks of power along the lines of the European monarchies, Ottoman commercial-statism emerged in parallel to the political infrastructure of the theocracy.

This division was accentuated by the growing extensiveness of European channels of ideological power. The segmentalised nature of the Ottoman periphery left it particularly vulnerable to such cultural expansion. Within the diffuse economic networks of non-Muslim millets, modernist European thought immanently reinforced the position of ascendant mercantile elites providing, what Mann terms, normative pacification (or, in other words, a common set of authoritatively determined values offering a more cohesive basis for interaction than systems merely founded on exchange or coercion). Since the millet elites had enjoyed many centuries of institutionalised and often enforced ideological autonomy, Western notions of collective identity also proved to be a powerful basis for transcending the segmentalising effects of state policy. As a result, postEnlightenment rational instrumentalism began to increase both the 
intensiveness and extensiveness of proto-nationalist networks within the millets by challenging the ideologically-defined Ottoman superstructure. In this way, religious perceptions of group consciousness were eroded in favour of non-religious, or what Mann calls commercial statist, proto-nationalism.

\section{The Ideology of Modernism}

Indeed, according to Mann, a similar process had occurred in medieval Europe as the ideological structures that underpinned the organisational extensiveness of feudalism began to share power with the economic networks of emergent capitalism. Many commentators have, however, challenged Mann's account of the ecumene. They argue that it was the military power of the western European monarchs, rather than the normative pacification of the Papacy, which provided the authoritative basis for increasing trade. Here Mann's narrative is impaired by a lack of comparative breadth. By favouring a linear account of Western development, his claim that ideological networks, as a connection between the state with the masses, acquired causal powers that were intrinsically different from existent military and economic linkages, is considerably weakened. Significant support could have been found in an exploration of Ottoman methods of ideological organisation. There, Islam offered the state a highly immanent means of normative pacification largely independent of other power sources. Not only did the authoritative power of the ulema legitimise tributary systems of extraction, it also enforced the rule of the state through the shariab and the ör. By immanently incorporating the theocracy's juridical infra-structure, the state was able to segmentalise economic networks within civil society, prevent ideological transcendentalism inside its armed forces, recruit jibadis and maintain its agents as the empire's only significant surpluscollecting social group. In contrast to the mercantile dominated commercial-statism of ecumenical Europe, Istanbul presided over an ideological regime that was fundamentally anti-entrepreneurial. The 
ulema's highly centralised role controlling the education system and the judiciary, strengthened by its localised and autonomous recruitment and training system, acted as a hinge between the imperial centre and the Muslim periphery. Their network of judges and pedagogues permitted the state to maintain control over provincial cultural traditions and artisan exchange thus ensuring that potentially decentralising networks remained intensively organised.

The centrality of the clerics' role in the Ottoman polity explains why non-religious modes of social explication imported from the West through the millets did not develop the extensiveness of the European commercial-statism. The ulema's greater capacity to resist the secularising influences of 'modernism' largely restricted the spread of proto-nationalism to non-Muslim peripheral elites. The threat of federalism and the territorial losses of the early part of the nineteenth century, however, reinforced the need to develop close infrastructural ties between the state and the imperial periphery. As a result, Istanbul greatly expanded its bureaucracy by incorporating ever-greater number of provincial recruits. Many of these represented prosperous ayan families alarmed at the comparative advantage and proto-nationalist irredentism of the millets. Thus, the new bureaucratic schools emerged as a locus for Muslim commercial-statism. Nonetheless, the ulema continued to retain their autonomous power base and 'modernist' thought remained restricted to a state elite largely excluded from the 'people' that they claimed to represent. As a result, influences from Europe were generally institutionalised in parallel to clerical traditionalism, the resilience of which meant that bureaucratic reforms, which led to a significant growth in non-clerical state administrators, were based on European models of the rational state imposed by Istanbul and unsupported by organic changes in civil society. Without the support of a diffused capitalist class, however, these social networks lacked extensive links to the mass of civil society. As a result, no broadly-held notions of citizenship comparable to those of Europe could be institutionalised. 
Another corollary of the lack of proto-nationalist extensiveness in the Ottoman empire was that the Porte remained highly autonomous Unlike in Europe, there emerged little resistance from the nascent Muslim middle-classes to the rise in state militarism during the nineteenth century. In much of the West, on the other hand, increases in state extraction to fund militarised geopolitical competition was, Mann suggests, regarded by much of the bourgeoisie as a process of retrogression thereby reinforcing nationalist sentiments. He argues that male, middle-class citizens from the dominant religious and ethnic groups, prompted by fears of populist radicalism in the wake of the French Revolution, began to define themselves as a nation to which the state should be coterminous. As a result, the trans-national trade-based elements of 'commercial statism' were gradually diminished and its 'proto-national' discursive media became imbued with, what Mann calls 'militarist' nationalism. In contrast to the decentralised growth of notions of exclusive political citizenship based on civil perceptions of 'the people' in western Europe, majority nationalism in the late Ottoman empire continued to be closely affiliated to the centrality of the state and its attempts to induce ideological change. Since both the late Ottoman empire and the early republic lacked comparable levels of capitalist diffusion, and thus the infra-structural means to connect the rural masses with the urban centre, entrepreneurial groups did not follow the Western model and seek greater power decentralisation and a more restricted economic role for the state. Instead, the centrism of western Anatolian mercantilism fused with the Istanbul intelligentsia to create an elite ideology that was largely unconnected to civil societal notions of popular sovereignty.

The failure to extend commercial-statism beyond an alliance of western Anatolian provincial elites and a state-affiliated coterie of literati led to a radicalisation of its nationalistic elements and a strengthening of state powers. It also meant that, rather than being centred on geopolitical expansion, chauvinist conceptions of Turkish 
nationhood were primarily aimed at increasing intra-state homogeneity. While European versions of militarist nationalism did contain notions of an internal threat, the more restricted progress of religious and commercial-statist proto-nationalism in the late Ottoman empire produced notions of militarist nationalism that were intensive rather than extensive. Thus, the modernising ideology and political growth of the inter-war republic was resisted in localised 'pockets' which tended to polarise state/civil and centre/periphery divides in a way which the more outward-looking militarism of nineteenth century Europe did not. In this sense, the greater territorial uniformity of the Western nation-states not only produced a more populist form of militarist nationalism, it also weakened the political efficacy of the peoples' internal enemy.

In the early years of the Turkish republic, on the other hand, the embattled defensiveness of the independence struggle, coupled with the ignominy of huge territorial loses, reinforced the need to institutionalise a more homogeneous polity. However, less mercantilist elites who had generally prospered little from European imperialism, continued to favour the loose political ties with the Ottoman centre which were embodied in the multi-ethnicity of the ummab-Caliph relationship. Therefore, Turkish militarist nationalism, unlike the old regime homogeneity of the nineteenth century European nation-state, was defined by an intra-elite conflict within both political and ideological power networks. As such, it became focused on institutionalising a wide-ranging programme of ideological reforms aimed at increasing the power of the state over decentralised organisational networks of theocratic traditionalism. Victory for Kemal, and the subsequent shift from religiously legitimised, multiethnic empire to secular, quasi-fascist republic through an enlarged network of state administrators, thus continued the Ottoman tradition of imposing political links upon the periphery from a despotic and highly autonomous core. The overall result was that, in contrast to Mann's Europe, Turkish militarist nationalism emerged as 
an intensive, intra-national, authoritarian-statist ideology rather than an extensively-held, predominantly geopolitical form of populist antistatism.

\section{The Economics of Liberalisation}

Centrally-planned economic development was a key area of the republican government's attempt to bring the masses closer to the power of the state. Here, Mann's account of late development and the institutionalisation of industrial-capitalist nationalism is particularly instructive. In common, with late nineteenth century policies in countries such as Sweden, Japan, Russia and Austria, Turkey established authoritative plans for greater industrialisation. During the 1930s, an extensive programme of infra-structural projects was initiated in Turkey. These were, in a similar way to industrialising countries in late nineteenth century Europe, aimed at boosting capital-intensive sectors such as mineral extraction, engineering and railway construction. As in Europe, this resulted in the emergence of huge cartels who relied heavily on the civil bureaucracy for subsidies, favourable lending terms and strategic planning and were, as a result, closely affiliated to the economic infra-structure of the state. In the militarised environment of late nineteenth century Europe, however, there existed an obvious geopolitical aspect to this form of industrialisation. The defensive protectionism of Turkish industrialcapitalism during the 1930s had no such facet. As a result, emergent manufacturers, mostly from western Anatolia, remained, in the absence of significant international links, authoritatively connected to the nationalist ideology and political infra-structure of the state bureaucracy.

As Mann points out, however, the long-term maintenance of such centralised power is extremely difficult to effect. Civil groups will, particularly through the more diffused networks of economic power, 
tend to build decentralised organisational linkages beyond the control of even authoritarian levels of state infra-structure. During the interwar period many large-estate farmers from western Anatolia became immensely wealthy and began to invest in urban centres. In doing so, they formed collective networks of power with occupational and professional groups originally developed by the state to support their bureaucracy's administration of the periphery. This eventually became the basis for integration with the industrial elite of western Anatolian cities. In keeping with Mann's account of European industrialcapitalist nationalism, this integrated elite also began to press for greater political representation within the centre, a decrease in military expenditure in favour of large-scale, state-led infra-structural enterprises, restraints upon the ever-growing bureaucracy's etatist controls and, primarily perhaps, greater international connections. Unlike in much of early-industrialising Europe, however, the subsequent growth in the state's civilian functions was not at the expense of local and regional identities.

As in Russia and Austria, the continuing economic power of the agrarian elite and their opposition to liberalising land reforms in Turkey tended to increase social instability and obstruct territorial cohesion. The result was that the extensive narrowing of the rural/urban divide which Mann argues was so indicative of early industrial-capitalist development failed to occur in these countries. Rather than the fairly evenly diffused, commercialised civil societies, which Mann identifies in some late-developers (such as Sweden and Japan), capitalist growth did not lead to a reduction in provincial diversity. In Turkey, this was exacerbated by the 1929 crash which ended the western Anatolian peasantry's partial marketisation, widened social stratification within the agrarian sector and further enhanced the power of conservative large-estate interests. Thus, as in Mann's characterisation of Austria and Russia, Turkish smallholders did not become proletarianised and remained a huge (still more than forty per cent of the population in 1945) and disparate workforce 
with little class consciousness. Moreover, unlike much of western Europe where a collective sense of citizenship produced mass political parties which obliged states to incorporate, however imperfectly, labour representation, Kemal's regime made no such acknowledgement. Instead, the republican state pursued the German imperial model of maintaining old regime rule through partial incorporation of the bourgeoisie. In all, the result was that neither within nor between non-elite Turkish agriculture and the urban workforce did there develop political links that could cohere class sentiment.

So, rather than purely as a consequence of features within the relations of production themselves, the emergence of class consciousness in Turkey was primarily prevented by a combination of sectional and sectoral factions similar to those which Mann identifies as key features of European industrial relations. In the Turkish case, these were significantly compounded by the persistence of three ageold and fundamentally non-economic cleavages - the divisions between the political centre and the periphery, state-affiliated and non-state affiliated actors and the differing institutions and development of eastern and western Anatolia. In both Turkey and western Europe, industrial-capitalism created only the potential for extensive, political and dialectical classes. Compartmentalised perceptions of social unity, illustrated through Mann's IOTA model, were, in both regions, rare. Neither produced extensively held notions of shared 'identity' nor of 'opposition' to other class interests. Similarly, these two components seldom combined to produce a perceived 'totality' that defined class members' social situation, nor did they generally offer an 'alternative' to existing power relations. In Turkey, as Mann concludes of Europe, classes did not emerge as 'pure' features of modernity. Instead, they were divided by other networks of social interaction, both from within the relations of production and through the influence of non-economic forces. The 
difference in Turkey was that these non-economic forces had much greater divisive power.

Not least was the growing differential between western and eastern Anatolia - especially the predominately Kurdish speaking south-east. As noted in Chapter Five, the peculiar artificiality of this area's border delimitation, its topography and its intensively localised culture made it particularly resistant to the political infra-structure of the centre. The result was that industrial-capitalism had little impact on the regions's local elites who continued, by and large, to maintain their position through a combination of traditional political power structures and corporatist links with the state. During the single-party period, the debilitating effects of the Sheikh Said rebellion and, in a reversal of Ottoman policies of state-imposed segmentalism, an extensive programme of state investment in the large agricultural estates of the Aegean and Mediterranean seaboards had exacerbated the west/east division still further. The result was that the emergence of industrial-capitalist nationalism failed to follow the more internationalist outlook of Sweden, Japan and the early developers. Only within the economic networks of the western Anatolian integrated elite, did such geopolitical concerns appear with any significant organisational power. Since, as Mann notes, industrialcapitalist advance, tends to empower the forces of political representation, this social group was, following its rise during the Second World War, successful in securing a process of political decentralisation by primarily citing the importance of joining the international order which emerged from Bretton Woods in 1944.

In other ways, however, industrial capitalism continued to be determined by the intra-state focus of the previous militarist phase thereby intensifying Turkey's internal divisions. For much of the old regime of bureaucrats and soldiers who had been forced to share power with the economic technocrats of the post-war middle-class governments, the new order was a heretical departure from the statist 
nationalism of Kemalist authoritarian dogma. For others, though, the advent of competitive politics and the arrival of the capitalist classes within the government of the republic was a natural continuation of Kemal's pro-Western populism. This cleavage ran right through the old regime. For the most part, the civil bureaucracy represented the former. They were largely divided between nationalist or pannationalist semi-religious authoritarianism - a partial reflection of Mann's characterisation of European state-affiliated rightism - and a more left-wing, reformist, yet equally anti-democratic, statism. The military, on the other hand, represented a wider spread of opinion, being ideologically unified only by a shared determination to improve their economic position. Within the officer corps, some welcomed the new bourgeois order as a means of organisationally outflanking leftist sentiment, 'nationalising' the state in a less coercive, 'Western' manner and endearing the republic to financial multi-laterals and their colleagues in NATO. Others, however, saw the presence of conservative farmers in government as an affront to their selfdesignated role as guardians of Kemalist reformism.

\section{The Military/Industrial Complex}

Parallels can be drawn between these fissures and Mann's account of the end of old regime preponderance following the First World War. $\mathrm{He}$ argues that, in countries which had institutionalised more authoritarian versions of industrial-capitalist nationalism, the pressure of growing civil demands for greater political representation, accentuated by the increasing organisational strength of decentralised economic networks, split the ruling classes into two factions - one conservatively committed to constitutional reform, the other advocating an anti-democratic, 'modernist' nationalism. In Turkey, a similar process materialised. The integrated elite and their merchant and professional affiliates had been successful in considerably diminishing the economic role and status of the old regime bureaucracy. In doing so, though, they radicalised rightist sentiment 
inside sections of the armed forces, especially within the field ranks of the officer corps. Thus, what Mann terns 'aggressive' modernist nationalism (or, in other words, chauvinist, xenophobic and militarist notions of cultural identity) appeared in Turkey in state careerist sectors of the military and civil bureaucracy in similar ways to Europe. Moreover, as in Western versions of modernist nationalism, the intensity of such views declined as seniority within the bureaucratic hierarchy increased. In both regions the staff commanders of the armed forces, for instance, tended to be both more cautious in geopolitical terns and less inclined towards radical reformist than less secure and more state-sensitive mid-ranking officers or bureaucrats.

Indeed, the Turkish high command's long-established propensity for centrist conservatism fitted well with the interests of the integrated economic elite. For their part, the industrialists were, by the late 1950s, much less reliant on provincial links and were therefore largely indifferent to the bourgeois government's policy of pandering to the peasantry in order to secure re-election. The result was a divergence between political and economic elite networks and a growing connection between industrial-capitalist interests and a military elite keen to position themselves within the new bourgeois order. In this sense, what emerged from the 1960 coup was an uneasy accommodation between the generals and the capitalist elite. Through considerable investments in the private sector and through an increasing role in publicly-funded economic projects, the military elite were at the heart of what turned out to be record growth rates during the 1960s. Much of the urban proletariat was, however, excluded from this period of prosperity and burgeoning leftist disorder prompted a number of authoritarian revisions to the 1961 constitution and an ever-closer relationship between the state and extreme right-wing activists.

This prevented the decline in 'aggressive' modernist nationalism apparent in most of Europe in the post-war era and maintained the 
military elite's close involvement in civil politics. Moreover, the inability of both bureaucratic and class rule to extend social citizenship and economic development to much of eastern Anatolia meant that the diminution in militarism, which Mann argues tends to accompany areas of uniformly organised capitalist exchange, also failed to occur in Turkey. Instead, the 1960s led to a further institutionalisation of aggressive notions of modernist national identity. Through a collusive arrangement with the integrated economic elite, the Turkish armed forces perpetuated a super-strong executive in the tradition of Ottoman monarchic office and, by continuing to repress labour organisation and favour quasi-fascist groups, ensured that no liberalising challenge could emerge with sufficient power to threaten their role as self-appointed and sole guardians of the 'organic' nation. While most European states experienced a considerable decline in domestic repression levels in the post-war era, militarised networks of political and ideological power within the Turkish state elite endured by accommodating dominant economic class ascendancy and institutionalising a semi-authoritarian, if highly volatile, version of what Mann identifies as a Bismarckian strategy of 'negative integration'. This afforded a controlled level of political expression for the emerging capitalist classes while maintaining a permanent position for military interests within the heart of government.

While liberal and totalitarian regimes tend to suffer from only limited levels of social conflict, being respectively inclusive and repressive enough to obviate rebellion, semi-authoritarian forms of incorporation are likely to be particularly prone to instability. This is because they are usually sufficiently exclusive to motivate challenges, but not despotic enough to suppress power-contentious organisations. By the end of the 1970s, it became clear in Turkey that a regime based on semi-authoritarian incorporation could not maintain organisational control over military power networks now much more decentralised, polarised by growing levels of violence and 
overlaid with ethnic and religious cleavages. As Islamist, rightist and left-wing organisations led an increasingly militarised challenge to the pro-Western capitalist order, the state began to lose organisational control over political power networks and to become isolated, producing a social vacuum which destabilised constitutional politics and consolidated bourgeois support for the Turkish armed forces. When proletariat unrest took on international dimensions (particularly through Iranian and Soviet connections), which appeared to jeopardise the elite's geopolitical and economic alignment with the West, the high command, following a number of key meetings with senior American agents, stepped in.

In this sense, the industrial/military cabal which assumed power in 1980 did not, as some commentators have claimed, represent a return of the old regime akin to the intervention of 1960 . Instead, the post1980 administration was based on a new elite coalition born of the high command's position in the domestic and global economy. This political manifestation had two primary sources of social power. Firstly, in economic terms, an accommodation had been reached between emergent capitalism and the old regime in which military power filled the organisational space vacated by the collapse of both the civil bureaucracy and elected officialdom thereby becoming, in the minds of much of the bourgeoisie, the only basis for a politically stable future. This was supported by a shared commitment to a root and branch revision of the economy. IMF-based structural adjustments were made to the exchange rate, the trading regime, monetary controls, public spending and debt management. In response, the international banks delivered a financial package of hitherto unprecedented size. Thus, coupled with Turkey's almost unrivalled arms purchasing programme, the obfuscatory Defence Industry Support Fund and the enormous military assistance foundations, the high command was able to assume a new position at the centre of Turkey's economy. 
Secondly, in ideological terms, a role had been found for the 'aggressive' nationalism of the junior field ranks by institutionalising, in effect, two systems of government. Outside south-east Anatolia, the military-industrial complex consolidated their political position by blending elements of what Mann calls the 'capitalist-liberal' regime strategy with the abiding semi-authoritarian techniques of incorporation still prevalent from the 1960s. As such, the vigorous promotion of free-market mercantilism was combined with moderately repressive measures against labour organisations and leftist groups. Legitimised through the pro-Western, classless ideology of Kemalism and the catch-all defence of national security and solidified by the growing embourgeoisment of the military elite, this combined structure became increasingly firmly embedded throughout the 1980s and 90 s. In economic terms, a similar policy was pursued in the south-east through numerous state-led attempts to extend capitalist links into the region and encourage private capital - most notably through the huge GAP initiative. However, the failure of this project to institutionalise territorially uniform free-market capitalism surrendered centralised control over networks of political power to 'aggressive' nationalists within the military hierarchy. The result was that over much of the ten predominantly Kurdish-speaking provinces of the south-east, a more autocratic regime emerged. Emergency legislation empowered an almost exclusively military system of governance in which nominally democratic institutions were rendered impotent by severe levels of domestic repression legitimised by threats to national security. Highly reformist assimilatory measures undertaken by field officers and irregular paramilitaries producing a regime quite different from the core areas of western Anatolia where the state deployed less coercive measures aimed at fragmenting potential class unity and promoting corporate interests. In this way, semi-authoritarian incorporation gave way to, what Mann terms, an 'autocratic militarist' regime in the south-east. The 1980 intervention's institutionalisation of such a bifurcated system of government thus represented, on the one hand, a means of managing ideological 
radicalism within the field ranks and, on the other, a way of establishing a thoroughly institutionalised collaboration between elite capital and high command conservatism.

\section{Conclusion}

In keeping with Mann's macro-historical rubric, outlined in Chapter Two, this thesis has thus presented an account of large-scale change in Ottoman/Turkish development with five primary objectives. Firstly, as set out in the opening section of this chapter, it has utilised an analysis of the past to consider more general propositions about social power and state-civil relations. Secondly, though the use of variant historical sources, it has constructed a causal analysis of the conditions which have given rise to modern institutions. Key areas of change have been summarised under four headings above. Thirdly, it has sought to understand the variation between Turkish and European social dynamics. A comparative analysis of this kind refines our understanding of large-scale change in the eastern Mediterranean in three ways. Firstly, in highlighting the commonalities which both regions possess, light can be cast on their shared socio-historical heritage. To this effect, the thesis has applied Mann's universal theory of power organisation and contention in order to elucidate social 'crystallisations' such as nationalism, secularism, class and militarism and economic development which are of general relevance. Secondly, by looking at the significant areas of difference between the two evolutionary patterns, a greater understanding of Turkish specificity can be obtained. Not least amongst these has been the rapidity of social change and the persistence of social cleavages built around ethnicity, religiosity and social status. Thirdly, in bringing a new case to Mann's account of historical continuity, a refined comprehension of social power can be sought which better explains Turkish patterns of organisational development. Significant points of comparative continuity and change within these three areas have also been highlighted in the preceding sections of this chapter. 
The fourth of the thesis' primary objectives has been to underline important areas of similarity and difference between Western and Eastern trajectories. As such, it attempts to rectify an omission in Mann's account and a Euro-centrism within macro-historical sociology generally. The fact that he fails to analyse both the differing imperial heritage of West and East and their contrasting institutionalisation of phenomena such as secularism, state centralisation and capitalism means that comparative aspects to his treatment of European social change are lost. Furthermore, he misses the opportunity to vary his historiographical argument with examples which might have reinforced his thesis on the specificity of northwest European development. This is a pity as a greater degree of contact with non-Western cases would have brought greater explanatory value to Mann's more general account of the emergence of the early nation-states. It would also have further allowed him to test his theoretical rubric and thus strengthen his claim upon general applicability. Nonetheless, Mann's analysis of European development offers the student of Middle Eastern history a useful scholarly tool. By selecting areas of both his theoretical and historiographic explication, insights into the emergence of Ottoman and Turkish social institutions can be obtained and, in the fifth and last of the thesis' objectives, Mann's contribution to historical sociology can be assessed.

In particular, this application of a leading approach within macrohistorical sociology offers support for the discipline as a whole. As with Mann's work, the thesis presented above seeks to adopt a holistic perspective without suggesting events have a teleological inevitability to them. Actors and their motives are linked to historical occurrences and processes both wittingly and as a result of unintended causes and consequences. Rather than referring to actors and events simply in terms of functional structures or role differentiation, this macro-historical approach emphasises the specific 
cultural and temporal context in which, and through which, phenomena were reported. In this sense, both this thesis and Mann's encyclopaedic analysis attempt to balance theoretical generality and social context. Or, put another way, each adopts a structured combination of nomothetic sociology and idiographic historiography in order to offer an explanatory account of variance and continuity within a deliberate and explicit analytical framework. As a result, methodological progress is made through the reformulation of the relationship between data and theory and new insights are made into the study of the past.

In seeking to advance a clearer understanding of long-term social transformations, macro-historical sociologists, like all scientists, are obliged to make extensive use of textual, or 'secondary', sources. However, in ensuring that such material is analysed and cross-checked in a detached and rigorous manner, the dialectical relationship between theory and data within macro-historical sociology provides the investigator with a distinct advantage over more rigid methodological formulations. By constantly relating evidence to variant hypotheses, differing spatial or temporal contexts and the study's own explicitly-stated sociological framework (see Chapters One and Two), theoretical adjustments can be made that lead to new interpretative analyses and stronger epistemological positions. So in not sticking to formulaic versions of, what Mann calls, 'the hypothetico-deductive sequence', historical sociologists can ask more general questions which, inherently, involve more approximate indicators and less comprehensive variables. Both Mann's account and this thesis have acknowledged these restraints and, in selecting the data which are presented, have outlined, or referenced, broader academic debates and returned to 'primary' historical sources wherever possible. In doing so, such studies are, firstly, equally likely to produce original findings. For instance, the main claims to originality within this thesis can be summarised thus: 
- There is currently no study of Turkish social development which seeks to trace large-scale changes in state power

- No analysis of Turkish social change has attempted the comprehensive diachronic comparisons with Western development set out here

- There has been no attempt to extend the theoretical components of macro-historical sociology to a specifically non-Western case

- No analyses of Ottoman change have attempted to deploy and develop a Spencerian model of compulsory cooperation. In doing so, this study has offered a revision to the widely-held view that the Roman empire represented as high a level of infra-structural power as was possible within pre-modern constraints

- In setting out a more complex theorisation of ideological power than is generally found in analyses of the modernist revolution in Turkey, this study has challenged the general opinion that the republican bureaucracy offered the state a means of developing a more cohesive polity

- No study offers such a comprehensive account of the integration of Turkish capital interests and its political consequences

- No study has argued that the post-1980 Kurdish issue in Turkey can be understood through an analysis of the internal dynamics of the military

Secondly, macro-historical sociological studies are, in essence, no different from more idiographic judgements about the factuality of the past. All tend to accept, reject or revise data, sources and 'secondary' interpretations according to the predominant social theories of the day. Rather than claiming a kind of positivist objectivity, or simply allowing these suppositions to lie implicitly within the analysis, however, macro-historical sociology generally sets out the assumptions upon which it proceeds through an explicit and comprehensive theoretical criterion. Thus, the thesis can be seen as a part of a broader return to a more ambitious approach to world issues over the last fifteen or so years. As Mann points out, the quest to understand "matters of nationalism and internationalism, authoritarianism and democracy, war and peace, and the peculiarities of states... [has] returned us to more macro traditions... [for] if we 
do not think in macro-sociological terms, then our empirical work will produce the conventional theories of own socialisation experiences".

${ }^{2}$ Mann, M. (1994) pp 46-47. My parentheses. 


\section{Bibliography:}

Abadan, $\mathrm{N}$.

1966 'Four elections of 1965: Turkey', Government and Opposition, Vol. 1, pp 335-344.

Ağaoğullanı, M.

1987 'The ultranationalist right', (trans. R. Benatar \& I. Schick) pp 177-218 in I. Schick \& E. Tonak (eds.), Turkey in Transition, New York, Oxford University Press.

Ahmad, F.

1969 The Young Turks: The Committee of Union and Progress in Turkish Politics, 1908-1914, London, Oxford University Press.

Ahmad, F.

1977 The Turkish Experiment in Democracy 1950-1975, London, C. Hurst.

Ahmad, F.

1980 Vanguard of a nascent bourgeoisie: The Social and economic policy of the Young Turks 1908-1918', pp 329-350 in O. Okyar \& H. İnalcik (eds.), Social and Economic History of Turkey (1071-1920), Ankara, Meteksan Sirkett.

Ahmad, F.

1981 'The political economy of Kemalism', pp 145-163 in A. Kazancigil, \& E. Özbudun (eds.), Ataturk: Founder of a Modern State, London, C. Hurst \& Co.

Ahmad, F.

1981a 'Military intervention and the crisis in Turkey', The Middle East Research and Information Project Reports, Washington DC No. 93.

Ahmad, F.

1982 'Unionist relations with the Greek, Armenian and Jewish communities of the Ottoman empire, 1908-1914', pp 401-434 in B. Braude \& B. Lewis (eds.), Christians and Jews in the Ottoman Empire: The Functioning of a Plural Society (Vol. I, New York, Holmes \& Meier.

Ahmad, F.

1988 'Islamic reassertion in Turkey', Third World Quarterly, Vol. 10, pp 750-769.

Ahmad, F. 
1991 'Politics and Islam in modern Turkey', Middle-Eastern Studies, Vol. 27, pp 3-21.

Ahmad, F.

1993 The Making of Modern Turkey, London, Routledge.

Akarl, E.

1975 'The state as a socio-cultural phenomenon and political participation in Turkey', pp 135-155 in E. Akarlı \& G. BenDor (eds.), Political Participation in Turkey, Istanbul, Boğazici University Publications.

Aktan, R.

1957 'Mechanisation of agriculture in Turkey', Land Economics, Vol. 33, pp 273-285.

Aktan, R.

1966 'Problems of land reform in Turkey', Middle East Journal, Vol. 20, pp 317-334.

Alderson, A.

1956 The Structure of the Ottoman Dynasty, London, Oxford University Press.

Alexander, A.

1961 'Turkey', pp 474-499 in A. Papelasis, L. Mears \& I. Adelman (eds.), Economic Development, Analysis and Case Studies, New York, Harper \& Row.

Alkan, $\mathrm{T}$.

1984 'The National Salvation Party in Turkey', pp 79-102 in M. Heper and R. Israeli (eds.), Islam and Politics in the Modern Middle East, New York, St. Martin's Press.

Althusser, L.

1977 For Marx, (trans. B. Brewster), London, New Left Books.

Altuğ, Y.

1984 'The development of constitutional thought in Turkey', pp 131-149 in A. Evin (ed.), Modern Turkey: Continuity and Change, Opladen, Leske Verlag \& Budrich Gmbh.

Anderson, $\mathrm{P}$.

1986 'Those in authority', Times Literary Supplement, December $12^{\text {th }}$, pp $1405-1406$.

Anderson, $\mathrm{P}$.

1990 'A culture in contraflow', New Left Review, No. 180, pp 4178.

Anderson, $\mathrm{P}$. 
1993 Lineages of the Absolute State (6 $6^{\text {th }}$ Ed.), London, Verso.

Andreski, S.

1971 Military Organisation and Society, Berkeley, University of California Press.

Arai, M.

1991 'Imagined nation: The idea of the Ottoman nation as a key to modern Ottoman history', Orient, Vol. 27, pp 1-11.

Arat, Y.

1991 'Politics and big business: Janus-faced link to the state', pp 135-148 in M. Heper (ed.), Strong State and Economic Interest Groups: The Post-1989 Experience, Berlin, de Gruyter.

Aresvik, O.

1975 The Agricultural Development of Turkey, New York, Praeger.

Aricanl, T.

1990 'The political economy of Turkey's external debt: The bearing of exogenous factors', pp 230-253 in T. Ancanll \& D. Rodrik (eds.), The Political Economy of Turkey: Debt. Adjustment and Sustainability, London, Macmillan.

Asad, M.

1980 The Message of the Qur'an, Gibraltar, Dar Al-Andalus.

Ayata, A.

1993 'Ideology, social bases, and organisation structure of the post1980 political parties', pp 31-49 in A. Eralp, M. Tünay \& B. Yeşilada (eds.), The Political and Socioeconomic Transformation of Turkey, London, Praeger.

Ayata, A.

1997 'The emergence of identity politics in Turkey', New Perspectives on Turkey, No. 17, pp 59-73.

Ayata, S.

1993 'The rise of Islamic fundamentalism and its institutional framework', pp 51-68 in A. Eralp, M. Tünay \& B. Yeşilada (eds.), The Political and Socioeconomic Transformation of Turkey, London, Praeger.

Ayata, $\mathrm{S}$.

1996 'Patronage, party and state: The politicisation of Islam in Turkey', Middle East Journal, Vol. 50, pp 40-57.

Bachrach, P. \& Baratz, M.

1962 'The two faces of power', American Political Science Review, Vol. 57, pp. 947-952. 
Baer, G.

1970 'The administrative, economic and social functions of Turkish guilds', International Journal of Middle East Studies, Vol. 1, pp 28-50.

Bailey, F.

1942 British Policy and the Turkish Reform Movement, Cambridge MA, Harvard University Press.

Baldus, $\mathrm{B}$.

1991 'Reply to Lenski', Canadian Journal of Sociology, Vol. 16, pp 195-201.

Barchard, D.

1985 Turkey and the West, London, Royal Institute of International Affairs.

Barkey, $\mathrm{H}$.

1984 'Crises of the Turkish political economy: 1960-1980', pp 47-63 in A. Evin (ed.), Modern Turkey: Continuity and Change, Opladen, Leske Verlag \& Budrich Gmbh.

Barkey, $\mathrm{H}$.

1990 Why military regimes fail: The perils of transition', Armed Forces and Society, Vol. 16, pp 169-192.

Barkey, $\mathrm{H}$.

1990a 'The State and the Industrialisation Crisis in Turkey, Boulder, Westview Press.

Barkey, $\mathrm{H}$.

1995 'Turkey, Islam and the Kurdish question', World Policy Journal, Vol. 13, pp 43-52.

Barkey, $\mathrm{H}$.

1996 'Under the gun: Turkish foreign policy and the Kurdish question', pp 65-84 in R. Olson (ed.), The Kurdish Nationalist Movement in the 1990s, London, The University Press of Kentucky.

Barkey, H. \& Fuller, G.

1997 'Turkey's Kurdish question: Critical turning points and missed opportunities', Middle East Journal, Vol. 51, pp 59-79.

Başkut, C., Kemal, Y. \& Güresin, E.

1960 Interviews With Members of Turkey's National Unity Committee, Washington DC, Joint Publications Research Service.

Baysan, T. \& Blitzer, C. 
1990 'Turkey's trade liberalisation in the 1980s and prospects for its sustainability', pp 9-36 in 'T. Arıcanlı \& D. Rodrik (eds.), The Political Economy of Turkey: Debt, Adjustment and Sustainability, London, Macmillan.

Bellah, R.

1968 'Religious aspects of modernisation in Turkey and Japan', pp 188-194 in J. Finkle \& R. Gable (eds.), Political Development and Social Change, New York, Wiley and Sons.

Bent, F.

1970 'The Turkish bureaucracy as an agent of change', Journal of Comparative Administration, Vol. 1, pp 47-64.

Berberoğlu, B.

1982 Turkey in Crisis, London, Zed Books.

Berkes, N. (ed.)

1959 Turkish Nationalism and Western Civilisation, London, Allen \& Unwin.

Berkes, $\mathrm{N}$.

1963 'Religious and secular institutions in comparative perspective', Archives de Sociologie des Religions, Vol. 15-16, pp 65-72.

Berkes, N.

1964 The Development of Secularism in Turkey, Montreal, McGill University Press.

Berkes, $\mathrm{N}$.

1974 'The two facets of the Kemalist revolution', Muslim World, Vol. 64, pp 292-306.

Berktay, $\mathrm{H}$.

1987 'The feudalism debate: The Turkish end - is 'tax vs. rent' necessarily the product and sign of a modal difference?', Journal of Peasant Studies, Vol. 14, pp 291-333.

Bianchi, R.

1984 Interest Groups and Political Development in Turkey, Princeton, Princeton University Press.

Birand, $\mathrm{M}$.

1987 The Generals' Coup in Turkey, London, Pergamon.

Birand, $\mathrm{M}$.

1991 Shirts of Steel: An Anatomy of the Turkish Armed Forces, London, I B Tauris.

Birtek, F. 
1994 'Prospects for a new centre of the temporary rise of the peripheral asabiyab?', pp 223-228 in M. Heper \& A. Evin (eds.), Politics in the Third Turkish Republic, Boulder, Westview Press.

Birtek, F. \& Keyder, Ç.

1975 'An inquiry into agricultural differentiation and political alliances: The case of Turkey', Journal of Peasant Studies, Vol. 2, pp 446-467.

Birtek, F. \& Toprak, B.

1993 'The conflictual agendas of neo-liberal reconstruction and the rise of Islamic politics in Turkey: The hazards of rewriting modernity', Praxis International, Vol. 13, pp 192-212.

Blaisdell, R.

1929 European Financial Control in the Ottoman Empire, New York, Columbia University Press.

Blalock, $\mathrm{H}$.

1984 Basic Dilemmas in the Social Sciences, Beverly Hills, Sage.

Blalock, $\mathrm{H}$.

1989 Power and Conflict, Newbury Park, Sage.

Blind, $\mathrm{K}$.

1896 'Young Turkey', Fortnightly Review, Vol. 62, pp 830-843.

Bölükbaşi, S.

1991 'Ankara, Damascus, Baghdad and the regionalisation of Turkey's Kurdish secessionism', Journal of South and Asian and Middle Eastern Studies, Vol. 14, pp 15-36.

Boratav, K.

1981 'Kemalist economic policies and etatism', pp 165-190 in A. Kazancigil, \& E. Özbudun (eds.), Atatürk: Founder of a Modern State, London, C. Hurst \& Co.

Boratav, K. \& Türel, O.

1988 'Notes on the current development problems and growth prospects of the Turkish economy', New Perspectives on Turkey, No. 9, pp 38-51.

Boratav, K.

1990 'Inter-class and intra-class relations of distribution under 'structural adjustment': Turkey during the 1980s', pp 199-229 in T. Arıcanls \& D. Rodrik (eds.), The Political Economy of Turkey: Debt. Adjustment and Sustainability, London, Macmillan.

Bozarslan, $\mathrm{H}$. 
1991 'Political aspects of the Kurdish problem', pp 95-114 in P. Kreyenbroek \& S. Sperl (eds.), The Kurds: A Contemporary Qverview, London, Routledge.

Bozarslan, $\mathrm{H}$.

1996 'Political crisis and the Kurdish issue in Turkey', pp 135-154 in R. Olson (ed.), The Kurdish Nationalist Movement in the 1990s, London, The University Press of Kentucky.

Brown, J.

1988 'Islamic fundamentalism and Turkey', Journal of Political and Military Sociology, Vol. 16, pp 235-246.

Brown, J.

1989 'The military and society: The Turkish case', Middle Eastern Studies, Vol. 25, pp 387-404.

Brown, J.

1995 'The Turkish imbroglio: its Kurds.' Annals of the American Political Science Society, 541, pp 116-129.

Bryant, J.

1992 'Positivism redivivus? A critique of recent uncritical proposals for reforming sociological theory (and related foibles)', Canadian Journal of Sociology, Vol. 17, pp 29-53.

Bryant, J.

1994 'Evidence and explanation in history and sociology: critical reflections on Goldthorpe's critique of historical sociology', British Journal of Sociology, Vol. 45, pp 3-19.

Buchanan, P. G.

1989 'State terror as a complement of economic policy' pp 33- 67 in G. A. Lopez and M. Stohl (eds.), Dependence, Development and Repression, New York, Greenwood Press.

Bulloch, J. \& Morris, H.

1993 No Friends but the Mountains, London, Penguin.

Burnham, J.

1942 The Managerial Revolution, London, Putnam.

Çağlar, A.

1990 'The greywolves as metaphor' [sic], pp 79-101 in A. Finkel \& N. Sirman (eds.), Turkish State, Turkish Society, London, Routledge.

Caldwell, $\mathrm{L}$.

1958 'Turkish administration and the politics of expediency', pp 117-144 in W. Siffin (ed.), Toward the Comparative Study of 
Public Administration, Bloomington, Indiana University Press.

Çandar, C.

1999 'Redefining Turkey's political centre', Journal of Democracy, Vol. 10, pp 129-141.

Carr, E. H.

1939 The Twenty Years Crisis, London, Macmillan.

Chambers, $\mathrm{R}$.

1964 'The civil bureaucracy', pp 301-327 in R. Ward \& D. Rustow (eds.), Political Modernisation in Japan and Turkey, Princeton, Princeton University Press.

Chambers, $\mathrm{R}$.

1972 'The Ottoman Ulema and the Tanzimat', pp 33-46 in $\mathrm{N}$. Keddie (ed.), Scholars, Saints and Sufis, Berkeley, University of California Press.

Chandler, $\mathrm{R}$.

1971 Travels in Asia Minor, London, Macmillan.

Chediac, J.

1980 'Turkish government brutally suppresses demonstrations', Workers World, January $4^{\text {th }}$, p. 13.

Chediac, J.

1980a 'Turkey on the road to revolution', Workers World, February $22^{\text {nd }}$, p. 7.

Chomsky, N.

2000 Rogue States: The Rule of Force in World Affairs, London, Pluto Press.

Cizre-Sakallığlu, Ü.

1991 'Labour: The battered community', pp 57-70 in M. Heper (ed.), Strong State and Economic Interest Groups: The Post1989 Experience, Berlin, de Gruyter.

Cizre-Sakallıoğlu, Ü.

1992 'Labour and state in Turkey: 1960-80', Middle Eastern Studies, Vol. 28, pp 712-728.

Cizre-Sakalloğlu, Ü.

1992a 'The ideology and politics of the National Action Party of Turkey', Cahiers D'etudes sur la Mediterranee Orientale et le Monde Turco-Iranien, No. 13, pp 141-164.

Cizre-Sakallığlu, Ü. 
1995 'Kemalism, Islam and hypernationalism', History of European Ideas, Vol. 20, pp 751-804.

Cizre-Sakallığlu, Ü.

1996 'Liberalism, democracy and the Turkish centre-right: The identity crisis of the True Path Party', Middle Eastern Studies, Vol. 32, pp 142-161.

Cizre-Sakallığlu, Ü.

1996a 'Parameters and strategies of Islam-state interaction in republican Turkey', International Journal of Middle Eastern Studies, Vol. 28, pp 231-251.

Cizre-Sakallıŏlu, Ü.

1997 'The anatomy of the Turkish military's political autonomy', Comparative Politics, Vol. 29, pp 151-166.

Clark, E.

1974 'The Ottoman industrial revolution', International Journal of Middle East Studies, Vol. 5, pp 65-76.

Cohn, E.

1970 Turkish Economic, Social and Political Change, New York, Praeger.

Coles, $\mathrm{P}$.

1968 The Ottoman Impact on Europe, London, Thames and Hudson.

Cornell, S.

1999 'Turkey: Return to stability', Middle Eastern Studies, Vol. 35, pp 209-234.

Coser, L.

1956 The Functions of Social Conflict, New York, The Free Press.

Cousins, J.

1973 Turkey: Torture and Political Persecution, London, Pluto Press.

Couturier, $\mathrm{K}$.

1996 'Ignoring US, Turkey and Iran sign trade accords', The Washington Post, December 22 ${ }^{\text {nd }}$, p. A31.

Cumberland, W.

1924 'The public treasury', pp 384-410 in E. Mears (ed.), Modern Turkey, New York, Macmillan.

Curtis, $M$.

1968 Comparative Government and Politics, New York, Harper \& Row. 
Dag1, I.

1996 'Democratic transition in Turkey, 1980-1983: The impact of European diplomacy', pp 124-142 in S. Kedourie (ed.), Turkey: Identity, Democracy and Politics, London, Frank Cass.

Dahl R.

1958 'A critique of the ruling elite model', American Political Science Review, Vol. 52, No. 2, pp. 463-469.

Dahl, R.

1961 Who Governs? Democracy and Power in an American City, Yale, Yale University Press.

Dahl, R.

1963 Modern Political Analysis, Englewood Cliffs N. J., PrenticeHall.

Dahl, R. \& Lindblom, C.

1953 Politics, Economics and Welfare, New York, Harper and Brothers.

Danielson, M. \& Keles, R.

1980 'Urbanisation and income distribution in Turkey', pp 269-309 in E. Özbudun \& A. Ulusan (eds.), The Political Economy of Income Distribution in Turkey, New York, Holmes \& Meier.

Daver, B.

1967 'Secularism in Turkey', Siyasal Bilgiler Fakultesi Dergisi, Ankara University, Vol. 22, pp 55-66.

Davies, J.

1962 'Toward a theory of revolution', American Sociological Review, Vol. 27, pp 5-9.

Davison, R.

1954 'Turkish attitudes concerning Christian-Muslim equality in the nineteenth century', American Historical Review, Vol. 59, pp 844-864.

Davison, $\mathrm{R}$.

1961 'Westernised education in Ottoman Turkey', Middle East Journal, Vol. 15, pp 289-301.

Davison, R.

1963 Reform in the Ottoman Empire 1856-1876, Princeton, Princeton University Press.

Davison, $\mathrm{R}$. 
1963a 'Turkish diplomacy from Mudros to Lausanne', pp 172-209 in G. Craig \& F. Gilbert (eds.), The Diplomats 1919-1939, New York, Athenaeum.

Davison, $\mathrm{R}$.

1964 'Environmental and foreign contributions: Turkey', pp 91-116 in R. Ward, \& D. Rustow (eds.), Political Modernisation in Japan and Turkey, Princeton, Princeton University Press.

Davison, $\mathrm{R}$.

1968 'The advent of the principle of representation in the government of the Ottoman Empire', pp 93-108 in W. Polk \& $\mathrm{R}$ Chambers (eds.), Beginnings of Modernisation in the Middle-East, Chicago, Chicago University Press.

Davison, $\mathrm{R}$.

1977 Nationalism as an Ottoman problem and the Ottoman response', pp 25-56 in W. Haddad \& -W. Ochsenwald (eds.), Nationalism in a Non-National State: The Dissolution of the Ottoman Empire, Columbus, Ohio State University Press.

Davison, R.

1982 'The millets as agents of change in the nineteenth century Ottoman empire', pp 319-338 in B. Braude \& B. Lewis (eds.), Christians and Jews in the Ottoman Empire: The Functioning of a Plural Society (Vol. I), New York, Holmes \& Meier.

Davison, $R$.

1987 'How the Ottoman government adjusted to a new institution: The newspaper press', pp 17-26 in S. Akural (ed.), Turkic Culture: Continuity and Change, Bloomington, Indiana University Turkish Studies No. 6.

De Jouvenel, B.

1958 'Authority: The efficient imperative', pp 160-170 in C. J. Friedrich (ed.), Authority, Cambridge MA, Harvard University Press.

Deringil, S.

1991 'Legitimacy structures in the Ottoman state: The reign of Abdulhamid II', International Journal of Middle East Studies, Vol. 23, pp 345-359.

Deringil, S.

1993 'The invention of tradition as public image in the late Ottoman empire, 1808-1908', Comparative Studies in Society and History, Vol. 35, pp 3-29.

Deringil, $S$. 
1993a 'The Ottoman origins of Kemalist nationalism: Namik Kemal to Mustafa Kemal', European History Quarterly, Vol. 23, pp 165-191.

Deringil, S.

1998 The Well-Protected Domains: Ideology and the Legimation of Power in the Ottoman Empire 1876-1909, London, I. B. Tauris.

Derviş, K. \& Robinson, S.

1980 'The structure of income inequality in Turkey', pp 83-122 in E. Özbudun \& A. Ulusan (eds.), The Political Economy of Income Distribution in Turkey, New York, Holmes \& Meier.

Devereux, $\mathrm{R}$.

1963 The First Ottoman Constitutional Period, Baltimore, The John Hopkins Press.

Dodd, C.

1969 Politics and Government in Turkey, Manchester, Manchester University Press.

Dodd, C.

1979 Democracy and Development in Turkey, Walkington, The Eothen Press.

Dodd, C.

1983 The Crisis of Turkish Democracy, Beverley, The Eothen Press.

Dodd, C.

1996 'Developments in Turkish democracy', pp 131-140 in V. Mastny \& C. Nation (eds.), Turkey Between East and West, Boulder, Westview Press.

Dumont, $\mathrm{P}$.

1984 'The origins of Kemalist ideology', pp 25-45 in J. Landau (ed.), Ataturk and the Modernisation of Turkey, Boulder, Westview Press.

Dumont, $\mathrm{P}$.

1987 'Islam as a factor of change and revival in modern Turkey', pp 1-15 in S. Akural (ed.), Turkic Culture: Continuity and Change, Bloomington, Indiana University Press.

Easton, D.

1958 'The perception of authority and political change', pp 170-197 in C. J. Friedrich (ed.), Authority, Cambridge MA, Harvard University Press.

Ecevit, B. 
1973 'Labour in Turkey as a new social and political force', pp 151181 in K. Karpat (ed.), Social Change and Politics in Turkey: A Structural-Historical Analysis, Leiden, E. J. Brill.

Edib, $\mathrm{H}$.

1928 The Turkish Ordeal, New York, Century Press.

Edwards, R,

1979 Contested Terrain, New York, Basic Books.

Eisenstadt, $\mathrm{S}$.

1969 The Political System of Empires, New York, Macmillan.

Eisenstadt, S.

1981 'The Kemalist revolution in comparative perspective', pp 127142 in A. Kazancigil \& E. Özbudun (eds.), Atatürk: Founder of a Modern State, London, C. Hurst \& Co.

Eisenstadt, $\mathrm{S}$.

1984 'The Kemalist regime and modernisation', pp 3-17 in J. Landau (ed.), Atatürk and the Modernisation of Turkey, Boulder, Westview Press.

El-Edroos, S. A.

1980 The Hashemite Arab Army, 1908-1979, Amman, The Publishing Committee.

Emerson, R.

1962 'Power dependence relations', American Sociological Review, Vol. 27, pp 31-41.

Emin, A.

1930 Turkey in the World War, New Haven, Yale University Press.

Emin, A.

1947 'The struggle for multi-party government in Turkey', Middle East Journal, Vol. 1, pp 47-69.

Entessar, N.

1989 'The Kurdish mosaic of discord', Third World Quarterly, Vol. $11, \mathrm{pp} 83-100$.

Entessar, N.

1992 Kurdish Ethnonationalism, Boulder, Lynne Rienner.

Ergil, D.

1975 'Class conflict and Turkish transformation', Studia Islamica, Vol. 6, pp 137-161.

Ergil, D.

1980 Türkiye'de Teror ve Siddet, Ankara, Turhan Kitabevi. 
Ergüder, Ü.

1988 'Post-1980 parties and politics in Turkey', pp 114-145 in E. Özbudun (ed.), Perspectives on Democracy in Turkey, Ankara, Turkish Political Science Association.

Ergüder, Ü.

1991 'The Motherland Party, 1983-1989', pp 152-170 in M. Heper \& J. Landau (eds.), Political Parties and Democracy in Turkey, London, I. B. Tauris.

Ergüder, Ü. \& Hofferbert, R.

1987 'Restoration of democracy in Turkey? Political reforms and the elections of 1983', pp 19-45 in L. Lane (ed.), Elections in the Middle East, Boulder, Westview Press.

Ergüder, Ü. \& Hofferbert, R.

1988 'The 1983 general elections in Turkey', pp 81-102 in M. Heper (ed.), State, Democracy and the Military: Turkey in the 1980s, Berlin, Walter de Gruyter.

Eriksen, K., Kazamias, A., Okey, R \& Tomiak, J.

1991 'Governments and the education of non-dominant ethnic groups in comparative perspective', pp 389-417 in J. Tomiak (ed.), Schooling, Education Policy and Ethnic Identity, New York, New York University Press.

Eriksen, T.

1991 'Ethnicity versus nationalism', Journal of Peace Research, Vol. 28, pp 268-285.

Eroğul, C.

1987 The establishment of multiparty rule: 1945-71', (trans. R. Benatar \& I. Schick) pp 101-143 in I. Schick \& E. Tonak (eds.), Turkey in Transition, New York, Oxford University Press.

Evans, M.

1994 From Machiavelli to Mann, The University of York Department of Politics Working Papers, No 8.

Evin, A.

1985 'Anti-Americanism in Turkey', pp 121-136 in A. Rubinstein \& D. Smith (eds.), Anti-Americanism in the Third World, New York, Praeger.

Evin, A.

1988 'Changing patterns of cleavage before and after 1980', pp 201213 in M. Heper (ed.), State, Democracy and the Military: Turkey in the 1980s, Berlin, Walter de Gruyter. 
Evin, A.

1994 'Demilitarisation and civilianisation of the regime', pp 23-40 in M. Heper \& A. Evin (eds.), Politics in the Third Turkish Republic, Boulder, Westview Press.

Faroqhi, S.

1994 'Crisis and change, 1590-1699', pp 411-636 in H. Inalckk (ed.), An Economic and Social History of the Ottoman Empire. Vol. 2.1600-1914, Cambridge, Cambridge University Press.

Faroqhi, S.

1999 Approaching Ottoman History, Cambridge, Cambridge University Press.

Findley, C.

1970 'The legacy of tradition to reform: Origins of the Ottoman foreign ministry', International Journal of Middle East Studies, Vol. 1, pp 347-365.

Findley, C.

1980 Bureaucratic Reform in the Ottoman Empire: The Sublime Porte, 1789-1922, Princeton, Princeton University Press.

Findley, C.

1980a 'Patrimonial household organisation and factional activity in the Ottoman ruling class', pp 227- 235 in O. Okyar \& H. Inalcik (eds.), Social and Economic History of Turkey (10711920), Ankara, Meteksan Sirketi.

Findley, C.

1982 'The advent of ideology in the Islamic Middle East', Studia Islamica, Vol. 16, pp 146-180.

Findley, C.

1986 'Economic bases of revolution and repression in the late Ottoman empire', Comparative Studies in Society and History, Vol. 28, pp 81-106.

Finkel, S., Muller, E. \& Opp, K.

1989 'Personal influence, collective rationality and mass political action', American Political Science Review, Vol. 83, pp 885903.

Finley, M.

1973 The Ancient Economy, London, Chatto \& Windus.

Fisher, $\mathrm{S}$.

1963 'The role of the military in society and government in Turkey', pp 21-40 in S. Fisher (ed.) The Military in the Middle East, Columbus, Ohio State University Press. 
Fox, C.

1967 'Turkish army's role in nationbuilding', Military Review, Vol. 67, pp 68-74.

Frey, F.

1963 'Political development, power and communication in Turkey', pp 47-69 in L. Pye (ed.), Communications and Political Development, Princeton, Princeton University Press.

Frey, F.

1964 'Education', pp 205-235 in R. Ward \& D. Rustow, (eds.), Political Modernisation in Japan and Turkey, Princeton, Princeton University Press.

Frey, F.

1965 The Turkish Political Elite, Cambridge MA, The MIT Press.

Frey, F.

1968 'Socialisation to national identification among Turkish peasants', Journal of Politics, Vol. 30, pp 934-965.

Frey, F.

1978 'Patterns of elite politics in Turkey', pp 41-82 in G. Lenczowski (ed.), Political Elites in the Middle-East, Washington DC, AEIPPR.

Froude, J.

1884 Short Studies on Great Subjects, London, Longmans.

Gellner, E.

1981 Muslim Society, Cambridge, Cambridge University Press.

Gençkaya, Ö.

1997 'Revival of the periphery: Need for consensus or threat to national integrity in Turkey' [sic], Journal of Behavioural and Social Sciences, Vol. 1, pp 75-90.

General Secretariat of the National Security Council

198212 September in Turkey: Before and After, Ankara

Gibb, H. \& Bowen, H.

1957 Islamic Society and the West, London, Oxford University Press.

Giddens, A.

1985 The Nation-State and Violence, Cambridge, Polity Press.

Göçek, F. M.

1993 'Ethnic segmentation, Western education and political outcomes: Nineteenth century Ottoman society', Poetics Today, Vol. 14, pp 507-538. 
Göçek, F. M.

1994 'Shifting the boundaries of literacy: Introduction of Westernstyle education to the Ottoman empire', pp 267-288 in D. Keller-Cohen (ed.), Literacy: Inter-Disciplinary Conversations, New Jersey, Hampton Press.

Göçek, F. M.

1996 Rise of the Bourgeoisie, Demise of Empire: Ottoman Westernisation and Social Change, New York, Oxford University Press.

Gökay, B.

1996 'Turkish settlement and the Caucasus, 1918-20', pp 45-76 in S. Kedourie (ed.), Turkey: Identity. Democracy and Politics, London, Frank Cass.

Gold, J.

1982 'Territoriality and human spatial behaviour', Progress in Human Geography, Vol. 6, pp 44-67.

Goldthorpe, J.

1991 'The uses of history in sociology: reflections on some recent tendencies', British Journal of Sociology, Vol. 42, pp 211-230.

Goldthorpe, J.

1994 'The uses of history in sociology: a reply', British Journal of Sociology, Vol. 45, pp 55-77.

Göle, N.

1994 'Toward and autonomisation of politics and civil society in Turkey', pp 213-222 in M. Heper \& A. Evin (eds.), Politics in the Third Turkish Republic, Boulder, Westview Press.

Göle, N.

1997 'Secularism and Islamism in Turkey: The making of elites and counter-elites', Middle East Journal, Vol. 51, No. 1, pp 46-58.

Gottlieb, G.

1994 'Nations without states', Foreign Affairs, Vol. 73, No. 3, pp 100-112.

Gramsci, A.

1971 Selections from the Prison Notebooks, London, Lawrence \& Wishart.

Günlük-Şenesen, G.

1995 'Some economic aspects of Turkish armaments spending', New Perspectives on Turkey, No. 13, pp 75-91.

Gunter, $M$. 
1988 'The Kurdish problem in Turkey', Middle East Journal, Vol. 42, pp 389-406.

Gunter, $M$.

1990 The Kurds in Turkey: a Political Dilemma, Boulder, West View Press.

Gunter, $\mathrm{M}$.

1994 The Changing Kurdish Problem in Turkey, London, Research Institute for the Study of Conflict And Terrorism.

Gunter, $M$.

1996 'Kurdish infighting: The PKK-KDP conflict', pp 50-65 in R. Olson (ed.), The Kurdish Nationalist Movement in the 1990s, London, The University Press of Kentucky.

Gunter, $M$.

2000 'The Continuing Kurdish Problem in Turkey After Öcalan's Capture', Third World Quarterly, Vol. 21, pp 849-870.

Gürbey, G.

1996 'The Kurdish nationalism movement in Turkey since the 1980s', pp 9-38 in R. Olson (ed.), The Kurdish Nationalist Movement in the 1990s, London, The University Press of Kentucky.

Gurr, T.

1970 Why Men Rebel, Princeton, Princeton University Press.

Gurr, T.

1993 Minorities at Risk: A Global View of Ethnopolitical Conflicts, Washington DC, United States Institute of Peace.

Haldon, J.

1991 'The Ottoman state and the question of state autonomy: Comparative Perspectives', Journal of Peasant Studies, Vol. 18, pp 18-10.

Hale, W.

1981 The Political and Economic Development of Modern Turkey, New York, St Martin's Press.

Hale, W.

1982 'The new Turkish education law', Index on Censorship, Vol. 11, pp 38-39.

Hale, W.

1984 'The traditional and the modern in the economy of Kemalist Turkey: The experience of the 1920s', pp 153-170 in J. Landau 
(ed.), Atatürk and the Modernisation of Turkey, Boulder, Westview Press.

Hale, W.

1988 'Transition to civilian government in Turkey: The military perspective', pp 159-175 in M. Heper (ed.), State, Democracy and the Military: Turkey in the 1980s, Berlin, Walter de Gruyter

Hale, W.

1990 'The Turkish army in politics, 1960-1973,' pp 53-78 in A. Finkel \& N. Sirman (eds.), Turkish State, Turkish Society, London, Routledge.

Hale, W.

1994 Turkish Politics and the Military, London, Routledge.

Halpern, M.

1963 The Politics of Social Change in the Middle East and North Africa, Princeton, Princeton University Press.

Hannum, $\mathrm{H}$.

1990 Autonomy, Sovereignty and Self-Determination, Philadelphia, University of Pennsylvania Press.

Harris, G.

1965 'The role of the military in Turkish politics, Part I \& Part II', The Middle East Journal, Vol. 19, pp 54-66 \& 169-176.

Harris, G.

1967 The Origins of Communism in Turkey, Stanford, Stanford University Press.

Harris, G.

1980 'The Left in Turkey', Problems of Communism, Vol. 29, pp 26-41.

Harris, G.

1985 Turkey: Coping With Crisis, Boulder, Westview Press.

Harris, G.

1988 The role of the military in Turkey in the 1980s: Guardians or decision makers?', pp 177-200 in M. Heper (ed.), State, Democracy and the Military: Turkey in the 1980s, Berlin, Walter de Gruyter.

Hart, N.

1994 'John Goldthorpe and the relics of sociology', British Journal of Sociology, Vol. 45, pp 21-30.

Heper, $M$. 
1976 'Political modernisation as reflected in bureaucratic change: The Turkish bureaucracy and a 'historical bureaucratic empire' tradition', International Journal of Middle East Studies, Vol. 7, pp 507-521.

Heper, $M$.

1976a 'The recalcitrance of the Turkish public bureaucracy to 'bourgeois politics': A multi-factor political stratification analysis', Middle East Journal, Vol. 30, pp 485-500.

Heper, M.

1977 Negative bureaucratic politics in a modernising context', Journal of South Asian and Middle Eastern Studies, Vol. 1, pp 65-84.

Heper, $M$.

1979 'Recent instability in Turkish politics: End of a monocentrist polity?', International Journal of Turkish Studies, Vol. 1, pp 102-113.

Heper, $M$.

1980 'Centre and periphery in the Ottoman empire with special reference to the nineteenth century', International Political Science Review, Vol. 1, pp 81-105.

Heper, $M$.

1981 'Islam, polity and society in Turkey: A Middle East perspective', Middle East Journal, Vol. 35, pp 345-363.

Heper, $M$.

1981a 'A methodological note on bureaucratic modernisation: Prevalent attitudes of the Turkish civil servants', International Review of Modern Sociology, Vol. 11, pp 47-69.

Heper, $M$.

1984 'Atatürk and the civil bureaucracy', pp 89-97 in J. Landau (ed.), Atatürk and the Modernisation of Turkey, Boulder, Westview Press.

Heper, $M$.

1984a 'Bureaucrats, politicians and officers in Turkey: Dilemmas of a new political paradigm', pp 64-83 in A. Evin (ed.), Modern Turkey: Continuity and Change, Opladen, Leske Verlag \& Budrich Gmbh.

Heper, $M$.

1985 The State Tradition in Turkey, Hull, The Eothen Press.

Heper, $M$.

1987 'The state, the military and democracy in Turkey', The Jerusalem Journal of International Relations, Vol. 9, pp 52-64. 
Heper, $\mathrm{M}$.

1990 'Turkey', pp 205-225 in V. Subramaniam (ed.), Public Administration in the Third World, New York, Greenwood Press.

Heper, $M$.

$1990 \mathrm{a}$ 'The executive in the third Turkish republic, 1982-1989', Governance, Vol. 3, pp 299-319.

Heper, $M$.

1990b 'The state and debureaucratisation: The case of Turkey', International Social Science Journal, Vol. 42, pp 605-615.

Heper, $M$.

1991 'The state, religion and pluralism: The Turkish case in comparative perspective', British Journal of Middle-Eastern Studies, Vol. 18, pp 38-51.

Heper, $M$.

1991a 'The state and interest groups with special reference to Turkey', pp 3-23 in M. Heper (ed.), Strong State and Economic Interest Groups: The Post 1980 Experience, Berlin, De Gruyter.

Heper, $M$.

$1991 \mathrm{~b}$ 'Interest-group politics in post-1980 Turkey, lingering monism', pp 163-176 in M. Heper (ed.), Strong State and Economic Interest Groups: The Post 1980 Experience, Berlin, De Gruyter.

Heper, M. \& Güney, A.

1996 'The military and democracy in the third Turkish republic', Armed Forces and Society, Vol. 22, pp 619-642.

Hershlag, Z.

1958 Turkey: An Economy in Transition, The Hague, Mouton.

Hershlag, Z.

1968 Turkey: The Challenge of Growth, Leiden, E J Brill.

Hershlag, Z.

1984 'Atatürk's etatism', pp 171-180 in J. Landau (ed.), Atatürk and the Modernisation of Turkey, Boulder, Westview Press.

Heyd, U.

1954 Language Reform in Modern Turkey, Jerusalem, The Israel Oriental Society.

Heyd, U. 
1961 'The Ottoman ulema and Westernisation in the time of Selim III and Mahmud II', Scripta Hierosolymitana, Vol. 9, pp 63 96.

Hintze, $\mathrm{O}$.

1975 The Historical Essays of Otto Hintze, (trans. F. Gilbert), New York, Oxford University Press.

Hirsch, A. \& Hirsch, E.

1966 'Changes in the terms of trade on farmers and their effect on real farm income per capita of rural population in Turkey: 1927-1960', Economic Development and Cultural Change, Vol. 14, pp 440-457.

Horowitz, D.

1985 Ethnic Groups in Conflict, London, University of California Press.

Hourani, A.

1968 'Ottoman reform and the politics of notables', pp 46-54 in W. Polk \& R. Chambers (eds.), Beginnings of Modernisation in the Middle-East, Chicago, Chicago University Press.

Hourani, A.

1970 Arabic Thought in the Liberal Age (1798-1939), London, Oxford University Press.

Hourani, A.

1974 'The Ottoman background to the modern Middle-East', pp 61-78 in K. Karpat (ed.), The Ottoman State and its Place in World History, Leiden, E. J. Brill.

Houston, C.

1997 'Islamic solutions to the Kurdish problem: Late rendezvous or illegitimate shortcut?', New Perspectives on Turkey, No. 16, pp 1-22.

Huntington, S.

1968 Political Order in Changing Societies, New Haven, Yale University Press.

Hyland, $M$.

1970 'Crisis at the polls: Turkey's 1969 elections', Middle East Journal, Vol. 24, pp 1-16.

Hyman, A.

1988 Elusive Kurdistan: The Struggle for Recognition, London, Institute for the Study of Conflict.

Hyman, H., Payaslioğlu, A. \& Frey, F. 
1958 'The values of Turkish college youth', Public Opinion Quarterly, Vol. 22, pp 275-291.

İkin, S.

1993 'Businessmen: Democratic stability', pp 177-198 in M. Heper, A. Öncü \& H. Kramer (eds.), Turkey and the West, London, I B Tauris.

İmset, $\dot{I}$.

1992 The PKK 1973-1992: A report on separatist violence in Turkey, Ankara, Turkish Daily News Publications.

Inalcik, $\mathrm{H}$.

1964 'The nature of traditional society: Turkey', pp 42-63 in R. Ward \& D. Rustow, (eds.), Political Modernisation in Japan and Turkey, Princeton, Princeton University Press.

İnalck, $\mathrm{H}$.

1968 'Islam in the Ottoman empire', Cultura Turcica, Vol. 5-7, pp 19-29.

İnalcik, $\mathrm{H}$.

1969 'Capital formation in the Ottoman empire', Journal of Economic History, Vol. 29, pp 97-140.

İnalcık, $\mathrm{H}$.

1970 'The Ottoman economic mind and aspects of the Ottoman economy', pp 207-218 in M. Cook (ed.), Studies in the Economic History of the Middle East, London, Oxford University Press.

İnalcik, $\mathrm{H}$.

1973 'Application of the Tanzimat and its social effects', Archivum Ottomanicum, Vol. 5, pp 97-127.

Inalcik, $\mathrm{H}$.

1975 The socio-political effects of the diffusion of fire-arms in the Middle-East', pp 195-217 in V. Parry \& M. Yapp (eds.), War. Technology and Society in the Middle-East, London, Oxford University Press.

Inalcik, $\mathrm{H}$.

1976 'The rise of the Ottoman empire', pp 2-54 in M. Cook (ed.), $\underline{A}$ History of the Ottoman Empire to 1730, Cambridge, Cambridge University Press.

İnalcık, $\mathrm{H}$.

1977 'Centralisation and decentralisation in Ottoman administration', pp 27-52 in T. Naff \& R. Owen (eds.) Studies in Eighteenth Century Islamic History, Carbondale and Edwardsville, Southern Illinois University Press. 
İnalck, $\mathrm{H}$.

1980 'Military and fiscal transformation in the Ottoman empire, 1600-1700', Archivum Ottomanicum, Vol. 6, pp 283-357.

İnalck, $\mathrm{H}$.

1982 'The Caliphate and Atatürk's inkelab', Belleten, Vol. 23, pp 353-365.

Inalcik, $\mathrm{H}$.

1994 An Economic and History of the Ottoman Empire Vol. 1. 1300-1600, Cambridge, Cambridge University Press.

Işıklı, A.

1987 'Wage labour and unionisation', (trans. R. Margulies \& I. Schick) pp 309-332 in I. Schick \& E. Tonak (eds.), Turkey in Transition, Oxford, Oxford University Press.

İslamoğlu, $\mathrm{H}$

1987 'State and peasants in the Ottoman empire: A study of peasant economy in north-central Anatolia during the sixteenth century', pp 101-159 in H. İslamoğlu-İnan (ed.), The Ottoman Empire and the World Economy, Cambridge, Cambridge University Press.

İslamoğlu, H. \& Keyder, Ç

1981 'The Ottoman social formation', pp 301-324 in A. Bailey \& J. Llobera (eds.), The Asiatic Mode of Production, London, Routledge and Kegan Paul.

İslamoğlu, H. \& Keyder, C..

1987 'Agenda for Ottoman history', pp 42-62 in H. İslamoğlu-İnan (ed.), The Ottoman Empire and the World Economy, Cambridge, Cambridge University Press.

Issawi, C.

1982 'The transformation of the economic position of the millets in the nineteenth century', pp 261-286 in B. Braude \& B. Lewis (eds.), Christians and Jews in the Ottoman Empire: The Functioning of a Plural Society (Vol. I), New York, Holmes \& Meier.

Itzkowitz, $\mathrm{N}$.

1962 'Eighteenth century Ottoman realities', Studia Islamica, Vol. 16, pp 73-94.

İzady, M.

1990 'Persian carrot and Turkish stick: contrasting policies targeted at gaining state loyalty from Azeris and Kurds', Kurdish Times, Vol. 3, pp 31-47. 
Jacobsen, $\mathrm{T}$.

1970 Towards the Image of Tammuz and other Essays in Mesopotamian History and Culture, Cambridge MA, Harvard University Press.

Jacoby, $T$.

1998 'Social power and the Turkish state: An historical approach to the Kurdish question', unpublished M.A thesis. University of Kent at Canterbury.

Jafar, M.

1976 Under-Underdevelopment: A Regional Case Study of the Kurdish Area in Turkey, Helsinki, Social Policy Association.

Jenkins, G.

1997 'Army fights enemies on both fronts', The European, May $22^{\text {nd }}-28^{\text {th }}$, p. 5.

Jessop, B.

1990 State Theory: Putting the Capitalist State in its Place, University Park, Pennsylvania State University Press.

Kadıŏlu, A.

1996 'The paradox of Turkish nationalism and the construction of official identity', pp 177-193 in S. Kedourie (ed.), Turkey: Identity, Democracy and Politics, London, Frank Cass.

Kalaycıŏlu, E.

1994 'Decentralisation and government', pp 87-100 in M. Heper \& A. Evin (eds.), Politics in the Third Turkish Republic, Boulder, Westview Press.

Kalaycıŏlu, E.

1997 'The logic of contemporary Turkish politics', Middle East Review of International Affairs, Vol. 1, http://www.biu.ac.il/SOC/besa/meria/journal/1997/issue3/ jv1n3a6.html.

Kaplan, A.

1968 'Positivism', International Encyclopaedia of the Social Sciences, Vol. 12, pp 389-395.

Karabelias, G.

1999 'The evolution of civil-military relations in post-war Turkey', Middle Eastern Studies, Vol. 35, pp 130-151.

Karal, E. Z.

1982 Non-Muslim representatives in the first constitutional assembly, 1876-1877', pp 387-400 in B. Braude \& B. Lewis (eds.), Christians and Jews in the Ottoman Empire: The 
Functioning of a Plural Society (Vol. I), New York, Holmes \& Meier.

Karaman, L.

1997 'Tunalı Hilmi: An outstanding figure in the process of ideological change from Ottomanism to Turkism', Middle East Review of International Affairs, Vol. 1, http://www.biu.ac.il/SOC/besa/meria/journal/1997/issue2/ jv1n2a9.html

Karaosmanoğlu, A.

1991 'The international context of democratic transition in Turkey', pp 172-191 in G. Pridham (ed.), Encouraging Democracy: The International Context of Regime Transition in Southern Europe, Leicester, Leicester University Press.

Karaosmanoğlu, A.

1993 'Officers: Westernisation and democracy' pp 19-34 in M. Heper, A. Öncü \& H. Kramer (eds.), Turkey and the West, London, I B Tauris.

Karaosmanoğlu, A.

1994 'The limits of international influence for democratisation', pp 117-131 in M. Heper \& A. Evin (eds.), Politics in the Third Turkish Republic, Boulder, Westview Press.

Karasapan, $\mathrm{O}$.

1987 'Turkey's armaments industry', Middle East Report, No. 144, pp 30-31.

Karl, T.

1986 'Imposing consent? Electoralism versus democratisation in El Salvador', pp 9-36 in P. Drake \& E. Silva (eds.), Elections and Democratisation in Latin America, 1980-1985, San Diego, University of California.

Karpat, K.

1959 Turkey's Politics: The Transition to a Multi-Party System, Princeton, Princeton University Press.

Karpat, K.

1960 'Social effects of farm mechanisation in Turkish villages', Social Research, Vol. 20, pp 83-103.

Karpat, K.

1960a 'Social themes in contemporary Turkish literature', Middle East Journal, Vol. 14, pp 29-44 and 153-168.

Karpat, K.

1962 'Recent political developments in Turkey and their social background', International Affairs, Vol. 38, pp 304-323. 
Karpat, K.

1964 'Society, economics and politics in contemporary Turkey', World Politics, Vol. 17, pp 50-74.

Karpat, $\mathrm{K}$.

1964a 'The mass media: Turkey', pp 255-282 in R. Ward \& D. Rustow, (eds.), Political Modernisation in Japan and Turkey, Princeton, Princeton University Press.

Karpat, $\mathrm{K}$.

1966 'The Turkish Left', Journal of Contemporary History, Vol. 1, pp 169-186.

Karpat, K.

1967 'Socialism and the Labour Party of Turkey', Middle East Journal, Vol. 21, pp 157-172.

Karpat, $K$.

1968 'The land regime, social structure and modernisation in the Ottoman Empire', pp 69-90 in W. Polk \& R Chambers (eds.), Beginnings of Modernisation in the Middle-East, Chicago, Chicago University Press.

Karpat, $\mathrm{K}$.

1969 'The Ottoman parliament of 1876 and its social significance', Proceedings of the International Association of South East European Studies, Sofia, pp 247-257.

Karpat, $\mathrm{K}$.

1970 The military and politics in Turkey: A socio-cultural analysis of a revolution', American Historical Review, Vol. 75, pp 1654-1683.

Karpat, $\mathrm{K}$.

1972 'The transformation of the Ottoman state, 1789-1908', International Journal of Middle Eastern Studies, Vol. 3, pp 243-281.

Karpat, $\mathrm{K}$.

1972a 'Political developments in Turkey, 1950-1970', Middle Eastern Studies, Vol. 8, pp 349-375.

Karpat, K.

1973 'Structural change, historical stages of modernisation and the role of social groups in Turkish politics', pp 11-92 in $\mathrm{K}$. Karpat (ed.), Social Change and Politics in Turkey: A Structural-Historical Analysis, Leiden, E. J. Brill.

Karpat, $\mathrm{K}$. 
1973a An Inquiry Into the Social Foundations of Nationalism in the Ottoman State, Research Monograph 39, Centre for International Studies, Princeton University.

Karpat, K.

1973b 'Ideology in Turkey after the revolution of 1960', pp 317-366 in K. Karpat (ed.), Social Change and Politics in Turkey: A Structural-Historical Analysis, Leiden, E. J. Brill.

Karpat, $\mathrm{K}$.

1974 'The stages of Ottoman history: A structural comparative approach', pp 79-98 in K. Karpat (ed.), The Ottoman State and its Place in World History, Leiden, E. J. Brill.

Karpat, K.

1976 The Gecekondu: Rural Migration and Urbanisation, Cambridge, Cambridge University Press.

Karpat, $K$.

1981 'Turkish democracy at impasse', International Journal of Turkish Studies, Vol. 2, pp 7-31.

Karpat, $\mathrm{K}$.

1982 'Millets and nationality: The roots of the incongruity of nation and state in the post-Ottoman era', pp 141-170 in B. Braude \& B. Lewis (eds.), Christians and Jews in the Ottoman Empire: The Functioning of a Plural Society (Vol. ID, New York, Holmes \& Meier.

Karpat, K.

1985 Ottoman Population 1830-1914, Madison, University of Wisconsin Press.

Karpat, K.

1988 'Military interventions: Army-civilian relations in Turkey before and after 1980', pp 137-159 in M. Heper (ed.), State, Democracy and the Military: Turkey in the 1980s, Berlin, Walter de Gruyter.

Kayal, $\mathrm{H}$.

1997 Arabs and Young Turks: Ottomanism, Arabism and Islamism in the Ottoman Empire 1908-1918, Betkeley, University of California Press.

Kazamias, A.

1966 Education and the Quest for Modernity in Turkey, London, George Allen \& Unwin Limited.

Kazancigil, A. 
1981 'The Ottoman-Turkish state and Kemalism', pp 37-57 in A. Kazancigil, \& E. Özbudun (eds.), Atatürk: Founder of a Modern State, London, C. Hurst \& Co.

Kazancigil, A.

1994 'High stateness in a Muslim society: The case of Turkey', pp 213-238 in M. Dogan \& A. Kazancigil (eds.), Comparing Nations: Concepts, Strategies, Substance, Oxford, Blackwell.

Keddie, N.

1972 Sayyid Jamal ad-Din “al-Afghani", Berkeley, University of California Press.

Keddie, N.

1988 'Ideology, society and the state in post-colonial Muslim societies', pp 11-47 in F. Halliday \& H. Alavi (eds.), State and Ideology in the Middle East and Pakistan, London, Macmillan.

Keddie, N.

1997 'Secularism and the state: Towards clarity and global comparison', New Left Review, No. 226, pp 21-40.

Kedourie, E.

1966 Afghani and Abduh, London, Frank Cass.

Kerr, M.

1966 Islamic Reform: The Political and Legal Theories of Muhammed Abduh and Rashid Rida, Berkeley, University of California Press.

Keyder, Ç.

1976 'The dissolution of the Asiatic mode of production', Economy and Society, Vol. 5, pp 178-196.

Keyder, Ç.

1980 'Ottoman economy and finances (1881-1918)', pp 323-328 in O. Okyar \& H. Inalckk (eds.), Social and Economic History of Turkey (1071-1920), Ankara, Meteksan Strketi.

Keyder, Ç.

1981 The Definition of a Peripheral Economy: Turkey 1923-1929, Cambridge, Cambridge University Press.

Keyder, Ç.

1987 State and Class in Turkey, London, Verso.

Keyder, Ç.

1987a 'Economic development and crisis', pp 293-308 in I. Schick \& E. Tonak (eds.), Turkey in Transition, Oxford, Oxford University Press. 
Keyder, Ç.

$1987 \mathrm{~b}$ 'The political economy of Turkish democracy', pp 27-65 in I. Schick \& E. Tonak (eds.), Turkey in Transition, Oxford, Oxford University Press.

Keyder, Ç.

1988 'Class and state in the transformation of modern Turkey', pp 191-221 in F. Halliday \& H. Alavi (eds.), State and Ideology in the Middle East and Pakistan, London, Macmillan.

Khaldoun, A. Ibn

1958 Al Muqaddimah, (trans. F. Rosenthal), New York, Pantheon Books.

Kibaroğlu, A.

1994 'Prospects for co-operation in the Euphrates-Tigris river basin', Turkish Review of Middle East Studies, Vol. 8, pp 137155.

Kindleberger, $\mathrm{C}$.

1973 The World Depression: 1929-1939, London, Penguin.

Kinnane, D.

1968 The Kurds and Kurdistan, London, Oxford University Press.

Kirişci, K.

1998 Minority/Majority discourse: The case of the Kurds in Turkey', pp 227-248 in D. Gladney (ed.), Making Majorities, Stanford, Stanford University Press.

Kirişci, K. \& Winrow, G.

1997 The Kurdish Question and Turkey: An Example of TransState Ethnic Conflict, London, Frank Cass.

Kiser, E.

1989 'A principal-agent analysis of the initiation of war in absolutist states', pp 65-82 in R. Schaeffer (ed.), War in the World System, New York, Greenwood.

Kiser, E. \& Hechter, M.

1991 The role of general theory in comparative-historical sociology', American Journal of Sociology, Vol. 97, pp 1-30.

Kissling, $\mathrm{H}$.

1954 "The sociological and educational role of the dervish orders in the Ottoman empire', American Anthropologist Memoir, No. 76, pp 23-35.

Kolars, J. 
1973 'The integration of the villager into the national life of Turkey', pp 182-202 in K. Karpat (ed.), Social Change and Politics in Turkey: A Structural-Historical Analysis, Leiden, E. J. Brill.

Kolars, J. \& Mitchell, W.

1991 The Euphrates and the Southeast Anatolian Development Project, Carbondale, Southern Illinois Press.

Korpi, W.

1974 'Conflict, power \& relative deprivation', American Political Science Review, Vol. 68, pp 1569-1578.

Kreyenbroek, $P$.

1993 'Religion and religions in Kurdistan', pp 85-110 in P. Kreyenbroek \& C, Allison (eds.), Kurdish Culture and Identity, London, Zed Books.

Krueger, A.

1974 Turkey, New York, National Bureau of Economic Research.

Kudat, A.

1975 'Patron-client relations: The state of the art and research in Eastern Turkey', pp 61-87 in E. Akarlı \& G. Ben-Dor (eds.), Political Participation in Turkey, Istanbul, Boğazici University Publications.

Kuran, E.

1962 'Ottoman historiography of the Tanzimat period', pp 422-429 in B. Lewis \& P. Holt (eds.), Historians of the Middle East, London, Oxford University Press.

Kurdish Human Rights Project

1996 Surviving for a Living: Report on the Current Conditions of Kurds in Turkey, London.

Kurdish Human Rights Project

1997 The HADEP Trial, London.

Kurdish Human Rights Project, Article 19 \& Medico International 1994 Freedom of the Press in Turkey: The Case of Özgur Gündem, London.

Kurdish Human Rights Project \& Medico International 1996 The Destruction of Villages in South-East Turkey, London.

Kurdish Human Rights Project \& Medico International 1997 Cultural and Language Rights of the Kurds, London.

Kushner, D. 
1977 The Rise of Turkish Nationalism: 1876-1908, London, Frank Cass.

Kutschera, C.

1994 'Mad dreams of independence: The Kurds of Turkey and the PKK', Middle East Report, Vol. 24, pp 12-19.

Laizer, S.

1996 Martyrs, Patriots and Traitors, London, Zed Books.

Landau, J.

1973 Middle East Themes: Papers in History and Politics, London, Frank Cass.

Landau, J.

1974 Radical Politics in Modern Turkey, Leiden, Brill.

Landau, J.

1976 Politics and Islam: The National Salvation Party in Turkey, Salt Lake City, University of Utah Press.

Landau, J.

1981 Pan Turkism in Turkey: A Study in Irredentism, London, C. Hirst.

Landau, J.

1981a 'Islamism and secularism: The Turkish case', pp 361-382 in J. Landau (ed.), Studies in Judaism and Islam, Jerusalem, Magnes Press.

Landau, J.

1982 'The Nationalist Action Party in Turkey', Journal of Contemporary History, Vol. 17, pp 587-606.

LaPalombara, J. \& Weiner, $M$.

1966 'Conclusions: the impact of parties on political development', pp 399-439 in J. LaPalombara and M. Weiner (eds.), Political Parties and Political Development, Princeton, Princeton University Press.

Lasswell, H. \& Kaplan, A.

1952 Power and Society, London, Routledge \& Kegan Paul.

Lattimore, $\mathrm{O}$.

1962 Studies in Frontier History, London, Oxford University Press.

Lattimore, $\mathrm{O}$.

1962a Inner Asian Frontiers of China, Boston, Beacon Press.

Leder, A. 
1979 'Party competition in rural Turkey: Agent of change or defender of traditional rule', Middle Eastern Studies, Vol. 15, pp 82-105.

Lenczowski, G.

1956 The Middle East in World Affairs, Ithaca, Cornell University Press

Lenski, G.

1988 'Rethinking macrosociological theory', American Sociological Review; Vol. 53, pp 163-171.

Lenski, G.

1991 'Positivism's future - and sociology's', Canadian Journal of Sociology, Vol. 16, pp 187-194.

Leontief, W.

1971 'Theoretical assumptions and nonobserved facts', American Economic Review, Vol. 61, pp 1-7.

Lerner, D. \& Robinson, R.

1960 'Swords and ploughshares: The Turkish army as a modernising force', World Politics, Vol. 13 pp 19-44.

Levi, $\mathrm{M}$.

1981 'The predatory theory of rule', Politics \& Society, Vol. 10, pp 431-465.

Levy, A.

1971 'The Ottoman ulema and the military reforms of sultan Mahmud II', Asian and African Studies, Vol. 7, pp 13-39.

Levy, A.

1991 'The Justice Party, 1961-1980', pp 134-152 in M. Heper \& J. Landau (eds.), Political Parties and Democracy in Turkey, London, I. B. Tauris.

Lewis, B.

1937 'The Islamic guilds', Economic History Review, Vol. 3, pp 2537.

Lewis, $\mathrm{B}$.

1952 'Islamic revival in Turkey', International Affairs, Vol. 28, pp 38-48.

Lewis, $B$.

1953 'The impact of the French revolution on Turkey', Lournal of World History, Vol. 1, pp 105-125.

Lewis, B. 
1953a 'History-writing and national revival in Turkey', Middle Eastern Affairs, Vol. 4, pp 218-227.

Lewis, B.

1961 The Emergence of Modern Turkey, London, Oxford University Press.

Lewis, B.

1973 Islam in History, London, Alcove Press.

Lewis, G.

1966 'Islam in politics: Turkey', The Muslim World, Vol. 56, pp $231-236$

Lewis, G.

1976 'Political change in Turkey since 1960', pp 18-47 in W. Hale (ed.), Aspects of Modern Turkey, London, Routledge.

Lewis, G.

1984 'Atatürk's language reforms as an aspect of modernisation in the republic of Turkey', pp 195-213 in J. Landau (ed.), Atatürk and the Modernisation of Turkey, Boulder, Westview Press.

Lijphart, A.

1971 'Comparative politics and the comparative method', American Political Science Review, Vol. 65, pp 682-693.

Lijphart, A.

1991 'The power-sharing approach', pp 491-509 in J. V. Montville (ed.), Conflict and Peacemaking in Multiethnic Societies, Lexington MA, Lexington Books.

Ludington, N. \& Spain, J.

1983 'Dateline Turkey: The case for patience', Foreign Policy, Vol. 50, pp 161-189.

Lukes, S.

1974 Power: A Radical View, London, Macmillan.

Lupsha, P.

1971 'Explanation of political violence', Politics \& Society, Vol. 10, pp 89-104.

Machlup, F.

1963 'Are the social sciences really inferior?', pp 158-180 in M. Natanson (ed.), Philosophy of the Social Sciences, new York, Random House.

MacKenzie, K.

1974 Turkey After the Storm, London, Institute for the Study of Conflict. 
MacKenzie, $\mathrm{K}$.

1981 Turkey Under the Generals, London, Institute for the Study of Conflict.

Mango, A.

1999 'Atatürk and the Kurds', Middle Eastern Studies, Vol. 35, pp 1-25.

Mann, $M$.

1970 'The social cohesion of liberal democracy', American Sociological Review, Vol. 35, pp 423-439.

Mann, $\mathrm{M}$.

1973 Consciousness and Action Among the Western Working Class, London, Macmillan

Mann, $M$.

1975 'The ideology of intellectuals and other people in the development of capitalism', pp 275-308 in L. Lindberg et al (eds.), Stress and Contradiction in Modern Capitalism, Lexington MA, D. C. Heath.

Mann, M.

1977 'States, ancient and modern', Archives Europa Sociologica, Vol. 18, pp 262-298.

Mann, $M$.

1980 'State and society, 1130-1815: An analysis of English state finances', pp 165-208 in M. Zeitlin (ed.), Political Power and Social Theory, Vol. 1, Greenwich CN, JAI Press.

Mann, $M$.

1984 The autonomous power of the state: Its origins, mechanisms and results', Archives Europa Sociologica, Vol. 25, pp 185213.

Mann, $M$.

1986 The Sources of Social Power, Vol. I, Cambridge, Cambridge University Press.

Mann, $M$.

1988 States, War and Capitalism, Oxford, Blackwell.

Mann, $M$.

1992 'The emergence of modern European nationalism', pp 137165 in J. Hall \& I. Jarvie (eds.), Transition to Modernity: Essays on Power, Wealth and Belief, Cambridge, Cambridge University Press.

Mann, $M$. 
1993 The Sources of Social Power, Vol. II, Cambridge, Cambridge University Press.

Mann, $M$.

1993a Nation-states in Europe and other continents: Diversifying, developing, not dying', Daedalus, Vol. 122, pp 115-140.

Mann, $M$.

1994 'In praise of macro-sociology: a reply to Goldthorpe', British Journal of Sociology, Vol. 45, pp 37-54.

Mann, $M$.

1995 'A political theory of nationalism and its excesses', pp 44-64 in S. Periwal (ed.), Notions of Nationalism, Budapest, Central European Press.

Mann, $M$.

$1995 \mathrm{a}$ 'Sources of variation in working-class movements in Twentieth century Europe', New Left Review, No. 212, pp 14-54.

Mann, $\mathrm{M}$.

1997 'The contradictions of continuous revolution', pp 135-157 in I. Kershaw \& M. Lewin (eds.), Stalinism and Nazism: Dictatorships in Comparison, Cambridge, Cambridge University Press.

Mann, $M$.

1999 'The dark side of democracy: The modern tradition of ethnic and political cleansing', New Left Review, No. 235, pp 18-45.

Mann, $M$.

2000 'The intended and unintended development of European social virtues', Keynote speech to the Biannual Meeting of the International Society for the Study of European Ideas, Bergen, Norway.

Mardin, S.

1960 'The mind of the Turkish reformer', Western Humanities Review, Vol. 15, pp 413-436.

Mardin, S.

1961 'Some notes on the early phase in the modernisation of communications in Turkey', Comparative Studies in Society and History, Vol. 3, pp 250-271.

Mardin, S.

1962 The Genesis of Young Ottoman Thought, Princeton, Princeton University Press.

Mardin, Ş. 
1962a 'Libertarian movements in the Ottoman empire 1878-1895', Middle East Journal, Vol. 16, pp 169-182.

Mardin, Ş.

1966 'Opposition and control in Turkey', Government and Opposition, Vol. 1, pp 375-387.

Mardin, Ş.

1967 'Historical determinants of stratification: Social class and class consciousness in Turkey', Siyasal Bigiler Kakultesi Dergisi, Vol. 22, pp 111-142.

Mardin, S.

1969 'Power, civil society and culture in the Ottoman Empire', Comparative Studies in Society and History, Vol. 2, pp 258281.

Mardin, Ş.

1971 'Ideology and religion in the Turkish revolution', International Journal of Middle Eastern Studies, Vol. 2, pp 197-211.

Mardin, Ş.

1973 'Centre-Periphery relations: a key to Turkish politics?', Daedalus, Vol. 102, pp 169-190.

Mardin, Ş.

1978 Youth and violence in Turkey', Archives Europa Sociologica, Vol. 19, pp 229-254.

Mardin, Ş.

1980 'Turkey: The transformation of an economic code', pp 23-53 in E. Özbudun \& A. Ulusan (eds.), The Political Economy of Income Distribution in Turkey, New York, Holmes \& Meier.

Mardin, S.

1981 'Religion and secularism in Turkey', pp 191-219 in A. Kazancigil \& E. Özbudun (eds.), Atatürk: Founder of a Modern State, London, C. Hurst \& Co.

Mardin, S.

1988 Religion and Social Change in Modern Turkey, Albany, State University of New York Press.

Margulies, R. \& Yıldizoğlu, E.

1987 'Agrarian Change: 1923-1970', pp 268-292 in I. Schick \& E. Tonak (eds.), Turkey in Transition, Oxford, Oxford University Press.

Matthews, A.

1955 Emergent Turkish Administrators, Ankara, Turk Tarih Kurumu Başimevi. 
McCarthey, J.

1980 'Greek statistics on the Ottoman Greek population', International Journal of Turkish Studies, Vol. 1, pp 67-84.

McClelland, D.

1967 The Achieving Society, London, The Free Press.

McCullagh, F.

1909 'The Constantinople mutiny of April 13 th', Fortnightly Review, Vol. 86, pp 58-69.

McDowall, D.

1989 The Alevi Kurds, London, Minority Rights Group.

McDowall, D.

1992 A Modern History of the Kurds, London, I. B. Tauris.

McDowall, D.

1993 The Kurds, a Nation Denied, London, Minority Rights Group.

McDowall, D.

1996 The Kurds, London, Minority Rights Group.

McFadden, J.

1985 'Civil-military relations in the third Turkish republic', The Middle East Journal, Vol. 39, pp 69-85.

McGarry, J. \& O'Leary B.

1993 The Politics of Ethnic Conflict Regulation, London, Routledge.

McGowan, B.

1994 'The age of the ayans, 1699-1812', pp 637-758 in H. Inalc1k (ed.), An Economic and Social History of the Ottoman Empire, Vol. 2, Cambridge, Cambridge University Press.

McNeil, W.

1972 'The Ottoman Empire in World History', pp 34-46 in K. Karpat (ed.), The Ottoman State and its Place in World History, Leiden, E. J. Brill.

Mears, E.

1924 'Transportation and communication', pp 201-237 in E. Mears (ed.), Modern Turkey, New York, Macmillan.

Mehmet, $\mathrm{O}$.

1983 'Turkey in crisis: Some contradictions in the Kemalist development strategy', International Journal of Middle Eastern Studies, Vol. 15, pp 47-66. 
Michels, R.

1911 Political Parties, London, Dover.

Mill, J. S.

1843 A System of Logic, London, Longmans.

Miller, B.

1941 The Palace School of Muhammad the Conqueror, Cambridge, Cambridge University Press.

Mills, C. Wright

1956 The Power Elite, Oxford, Oxford University Press.

Mills, C. Wright

1959 The Sociological Imagination, New York, Oxford University Press.

Mitchell, C.

1980 'Evaluating conflict', Lournal of Peace Research, Vol. 17, pp 61-75.

Mitchell, C.

1992 The Structure of International Conflict, London, Macmillan.

Mitrany, D.

1966 A Working Peace System, Chicago, Quadrangle Books.

Moore, B.

1967 Social Origins of Dictatorship and Democracy, London, Allen Lane.

Mosca, G.

1939 The Ruling Class, (trans. H. Kahn), London, McGraw-Hill.

Mouzelis, $\mathrm{N}$.

1994 'In defence of 'grand' historical sociology', British Journal of Sociology, Vol. 45, pp 31-36.

Mulhall, T.

1995 A review of 'The Sources of Social Power Volume Two', British Journal of Sociology, Vol. 46, pp 362-363.

Muller, E.

1985 'Income inequality, regime repressiveness, and political violence', American Sociological Review, Vol. 50, pp 47-61.

Muller, $M$.

1996 Nationalism and the rule of law in Turkey: The elimination of Kurdish representation during the 1990s', pp 173-200 in R. 
Olson (ed.), The Kurdish Nationalist Movement in the 1990s,

London, The University Press of Kentucky.

Murphey, R.

1980 'The construction of a fortress at Mosul in 1631' pp 163-178 in O. Okyar \& H. Inalcik (eds.), Social and Economic History of Turkey (1071-1920), Ankara, Meteksan Sirketi.

Narl, $N$.

1999 'The rise of the Islamist movement in Turkey', Middle East Review of International Affairs, Vol. 3, http://www.biu.ac. il/SOC/besa/meria/journal/1999/issue3/jv3n3a4.html.

Nathan, J.

1997 'Turkey on edge', International Relations, Vol. 13, pp 15-25.

Neyzi, $N$.

1973 'The middle classes in Turkey', pp 123-150 in K. Karpat (ed.), Social Change and Politics in Turkey: A Structural-Historical Analysis, Leiden, E. J. Brill.

Nezan, $K$.

1980 'Kurdistan in Turkey', (trans. M. Pallis) pp 47-106 in G. Chaliand (ed.), People Without a Country: The Kurds in Kurdistan, London, Zed Books.

Nieburg, H. L.

1962 'The threat of violence and social change', American Political Science Review, Vol. 52, pp 865-873.

Nigogosian, A.

1996 'Turkey's Kurdish problem in the 1990s', pp 38-50 in R. Olson (ed.), The Kurdish Nationalist Movement in the 1990s, London, The University Press of Kentucky.

Nordlinger, E.

1977 Soldiers In Politics: Military Coups and Governments, New Jersey, Prentice-Hall.

North, R. C., Koch, H. E. \& Zinnes, D. A.

1960 'The integrative functions of conflict', Journal of Conflict Resolution, Vol. 4, pp 355-374.

Nyrop, R. F.

1980 Turkey: A Country Study, Washington DC, The American University Press.

Oberschall, A.

1969 'Rising expectations \& political turmoil', Journal of Development Studies, Vol. 10, pp 5-23. 
Okyar, $\mathrm{O}$.

1965 'The concept of etatism', The Economic Journal, Vol. 75, pp 98-111.

Okyar, $\mathrm{O}$.

1984 'Atatürk's quest for modernisation', pp 45-53 in J. Landau (ed.), Atatürk and the Modernisation of Turkey, Boulder, Westview Press.

Olson, R. \& Bozdağhoğlu, Y.

1996 'The new democracy movement in Turkey...', pp 154-173 in R. Olson (ed.), The Kurdish Nationalist Movement in the 1990s, London, The University Press of Kentucky.

Olson, R.

1989 The Emergence of Kurdish Nationalism and the Sheikh Said Rebellion, Austin, Texas University Press.

Olson, R.

1996 'The Kurdish question and Turkey's foreign policy...', pp 84114 in R. Olson (ed.), The Kurdish Nationalist Movement in the 1990s, London, The University Press of Kentucky.

Öncü, A.

1980 'Chambers of commerce in Turkey: An inquiry into stateindustry relations as a distributive domain', pp 455-480 in E. Özbudun \& A. Ulusan (eds.), The Political Economy of Income Distribution in Turkey, New York, Holmes \& Meier.

Öncü, A.

1993 'Academics: The West in the discourse of university reform', pp 142-176 in M. Heper, A. Öncü \& H. Kramer (eds.), Turkey and the West, London, I B Tauris.

Öniş, Z.

1996 'The state and economic development in contemporary Turkey: Etatism to neoliberalism and beyond', pp 154-178 in V. Mastny \& C. Nation (eds.), Turkey Between East and West, Boulder, Westview Press.

Öniş, Z.

1997 'The political economy of Islamic resurgence in Turkey: The rise of the Welfare Party in perspective', Third World Quarterly, Vol. 18, pp 743-766.

Özbudun, E.

1966 The Role of the Military in Recent Turkish Politics, Cambridge MA, Harvard University Press.

Özbudun, E. 
1970 'Established revolution versus unfinished revolution: Contrasting patterns of democratisation in Mexico and Turkey', pp 380-405 in S. Huntington \& C. Moore (eds.), Authoritarian Politics in Modern Society: The Dynamics of Established One-Party Systems, New York, Basic Books.

Özbudun, E.

1976 Social change and Political Participation in Turkey, New Jersey, Princeton University Press.

Özbudun, E.

1980 'Income distribution as an issue in Turkish politics', pp 55-82 in E. Özbudun \& A. Ulusan (eds.), The Political Economy of Income Distribution in Turkey, New York, Holmes \& Meier.

Özbudun, E.

1981 'The nature of the Kemalist political regime', pp 79-102 in A. Kazancigil, \& E. Özbudun (eds.), Atatürk: Founder of a Modern State, London, C. Hurst \& Co.

Özbudun, E.

1981a The Turkish party system: Institutionalisation, polarisation and fragmentation', Middle Eastern Studies, Vol. 17, pp 228240.

Özbudun, E.

1984 'Antecedents of Kemalist secularism: Some thoughts on the Young Turk period', pp 25-44 in A. Evin (ed.), Modern Turkey: Continuity and Change, Opladen, Verlag \& Budrich.

Özbudun, E.

1988 'Development of democratic government in Turkey: Crises, interruptions and re-equilibriums' [sic], pp 1-58 in E. Özbudun (ed.), Perspectives on Democracy in Turkey, Ankara, Turkish Political Science Association.

Özbudun, E.

1988a 'Stages of political development in the Turkish republic', pp 59-112 in E. Özbudun (ed.), Perspectives on Democracy in Turkey, Ankara, Turkish Political Science Association.

Özbudun, E.

1989 'Development and consolidation of democracy in Turkey', pp 1-20 in E. Özbudun (ed.), Turkey in the Year 2000, Ankara, Turkish Political Science Association.

Özbudun, E.

1991 'The post-1980 legal framework for interest group associations', pp $41-54$ in M. Heper (ed.), Strong State and Economic Interest Groups: The Post-1989 Experience, Berlin, de Gruyter. 
Özbudun, E.

1993 'State elites and democratic political culture in Turkey', pp 247-268 in L. Diamond (ed.), Political Culture and Democracy in Developing Countries, Boulder, Lynne Rienner.

Özbudun, E.

1996 'Constitution making and democratic consolidation in Turkey', pp 229-243 in M. Heper, A. Kazancigil \& B. Rockman (eds.), Institutions and Democratic Statecraft, Boulder, Westview.

Özerdem, A. \& Barakat, S.

2000 'After the Marmara Earthquake: Lessons For Avoiding Shortcuts to Disaster', Third World Quarterly, Vol. 21, pp 425-440.

Pamuk, S.

1987 The Ottoman Empire and European Capitalism, 1820-1913, Cambridge, Cambridge University Press

Pamuk, S.

1994 'Money in the Ottoman empire', pp 945-985 in H. Inalc1k (ed.), An Economic and Social History of the Ottoman Empire, Vol. 2, Cambridge, Cambridge University Press.

Pareto, V.

1916 The Mind and Society, London, Harcourt-Brace.

Parry, V.

1969 'Elite elements in the Ottoman empire', pp 50-73 in R. Wilkinson (ed.), Governing Elites, Oxford University Press, New York.

Parsons, $\mathrm{T}$.

1958 'Authority, legitimation and political action', pp 197-222 in C. J. Friedrich (ed.), Authority, Cambridge MA., Harvard University Press.

Parsons, $\mathrm{T}$.

1960 Societies: Evolutionary and Comparative Perspectives, Englewood Cliffs, Prentice Hall.

Parsons, $\mathrm{T}$.

1968 The Structure of Social Action, New York, The Free Press.

Paul, J.

1981 'The Coup', The Middle East Research and Information Project Reports, No. 92, Washington DC.

Pevsner, L. 
1984 Turkey's Political Crisis: Background, Perspectives, Prospects, New York, Praeger.

Polk, W. R. \& Chambers, R. L.

1990 'The advent of the principle of representation in the government of the Ottoman Empire', pp 96-112 in R. H. Davison (ed.), Essays in Ottoman and Turkish History 17741923, Austin, University of Texas Press.

Pollis, A.

1989 'State repression and development: the case of Turkey', pp 155-185 in G. A. Lopez and M. Stohl (eds.), Dependence. Development and Repression, New York, Greenwood Press.

Pope, N. \& Pope, $\mathrm{H}$.

1997 Turkey Unveiled, London, John Murray.

Popkin, S. L.

1979 The Rational Peasant, Berkeley, University of California Press.

Poulantzas, N.

1973 Political Power and Social Classes, (trans. O'Hagan, T.), London, New Left Books.

Presthus, R,

1964 Men at the Top, Oxford, Oxford University Press.

Quataert, D.

1977 'Limited revolution: The impact of the Anatolian railway on Turkish transportation and provisioning of Istanbul', Business History Review, Vol. 51, pp 139-160.

Quataert, D.

1983 Social Disintegration and Popular Resistance in the Ottoman Empire, 1881-1908, New York, New York University Press.

Quataert, D.

1994 'The age of reforms, 1812-1914', pp 759-944 in H. Inalclk (ed.), An Economic and Social History of the Ottoman Empire, Vol. 2, 1600-1914, Cambridge, Cambridge University Press.

Ramsaur, E.

1965 The Young Turks: Prelude to the Revolution of 1908, Beirut, Khayats.

Reed, $\mathrm{H}$.

1954 'Revival of Islam in secular Turkey', Middle East Journal, Vol. 8, pp 267-282.

Reed, $\mathrm{H}$. 
1957 'The religious life of modern Turkish Muslims', pp 108-148 in R. Frye (ed.), Islam and the West, The Hague, Mouton.

Reed, $\mathrm{H}$.

1957a 'Secularism and Islam in Turkish politics', Current History, Vol. 32, pp 333-338.

Reed, $\mathrm{H}$.

1980 'Ottoman reform and the janissaries: The eskenci layibasi of 1826', pp 193-198 in O. Okyar \& H. Inalc1k (eds.), Social and Economic History of Turkey (1071-1920), Ankara, Meteksan Sirketi.

Reed, $\mathrm{H}$.

1980a 'Atatürk's secularising legacy and the continuing vitality of Islam in republican Turkey', pp 316-339 in C. Pullapilly (ed.), Islam in the Contemporary World, Indiana, Cross Road Books.

Riggs, F.

1964 Administration in Developing Countries, Boston, Houghton Mifflin.

Robins, $\mathrm{P}$.

1991 Turkey and the Middle East, London, Pinter.

Robins, $\mathrm{P}$.

1993 'The overlord state: Turkish policy and the Kurdish issue', International Affairs, Vol. 69, pp 657-676.

Robins, $\mathrm{P}$.

1996 'More apparent than real? The impact of the Kurdish issue on Euro-Turkish relations', pp 114-135 in R. Olson (ed.), The Kurdish Nationalist Movement in the 1990s, London, The University Press of Kentucky.

Robinson, $\mathrm{R}$.

1963 The First Turkish Republic: A Case Study in National Development, Cambridge MA, Harvard University Press.

Rodkey, F.

1958 'Ottoman concern about Western economic penetration in the Levant, 1849-1856', Journal of Modern History, Vol. 30, pp 348-353.

Rodrigue, A.

1990 French Jews, Turkish Jews: The Alliance Israelite Universelle and the Politics of Jewish Schooling in Turkey 1860-1925, Bloomington, Indiana University Press.

Roos, N. \& Roos, L. 
1968 'Changing patterns of Turkish public administration', Middle Eastern Studies, Vol. 4, pp 270-295.

Rosenblatt, P.

1963 'Origins and effects of group ethnocentrism and nationalism', Journal of Conflict Resolution, Vol. 8, pp 131-146.

Roth, G.

1963 The Social Democrats in Imperial Germany, Totowa NJ, Beminister Press.

Rouleau, E.

1993 'The challenges to Turkey', Foreign Affairs, Vol. 72, pp 110126.

Runciman, W.

1987 'The old question', London Review of Books, February 19th, pp 7-8.

Russell, B.

1938 Power: A New Social Analysis, London, Allen \& Unwin.

Rustow, D.

1957 'Politics and Islam in Turkey, 1920-1955', pp 69-107 in R. Frye (ed.), Islam and the West, The Hague, Mouton.

Rustow, D.

1959 'The army and the founding of the Turkish republic', World Politics, Vol. 11, pp 513-552.

Rustow, D.

1964 'The military', pp 352-388 in R. Ward \& D. Rustow, (eds.), Political Modernisation in Japan and Turkey, Princeton, Princeton University Press.

Rustow, D.

1965 'The appeal of communism to Islamic peoples', pp 40-60 in J. Harris Proctor (ed.), Islam and International Relations, London, Pall Mall Press.

Rustow, D.

1966 'The development of parties in Turkey', pp 107-133 in J. LaPalombara and M. Weiner (eds.), Political Parties and Political Development, Princeton, Princeton University Press.

Rustow, D.

1967 'Politics and development policy', pp 5-32 in F. Shorter (ed.), Four Studies on the Economic Development of Turkey, London, Frank Cass.

Rustow, D. 
1968 'Atatürk as founder of a state', Daedalus, Vol. 97, pp 793-828.

Rustow, D.

1979 'Turkey's travails', Foreign Affairs, Vol. 58, pp 82-102.

Rustow, D.

1981 'Atatürk as an institution-builder', pp 57-78 in A. Kazancıgil \& E. Özbudun (eds.), Atatürk: Founder of a Modern State, London, C. Hurst \& Co.

Rustow, D.

1991 'Political parties in Turkey: An overview', pp 10-24 in M. Heper \& J. Landau (eds.), Political Parties and Democracy in Turkey, London, I. B. Tauris.

Sack, R. D.

1986 Human Territoriality, Cambridge, Cambridge University Press.

Salt, J.

1999 'Turkey's military democracy', Current History, February, pP 72-78.

Samim, A.

1987 'The Left', pp 147-176 in I. Schick \& E. Tonak (eds.), Turkey in Transition, Oxford, Oxford University Press.

Saran, N.

1974 'Squatter settlement (gecekondu) problems in Istanbul', pp 327-361 in P. Benedict, E. Tümertekin \& F. Mensur (eds.), Turkey: Geographic and Social Perspectives, Leiden, E. J. Brill.

Sarrbay, A.

1991 'The Democratic Party, 1946-1960', pp 119-134 in M. Heper \& J. Landau (eds.), Political Parties and Democracy in Turkey, London, I. B. Tauris.

Sartori, G.

1976 Parties and Party Systems: A Framework for Analysis, Cambridge, Cambridge University Press.

Sayar1, S.

1971 Party Politics in Turkey, Unpublished PhD dissertation, Columbia University.

Sayarı, S.

1977 'Political patronage in Turkey', pp 103-113 in E. Gellner \& J. Waterburg (eds.), Patrons and Clients in Mediterranean Societies, London, Duckworth.

Schick, I. \& Tonak, E. 
1987 'The international dimension: Trade, aid and debt', pp 333363 in I. Schick \& E. Tonak (eds.), Turkey in Transition, Oxford, Oxford University Press.

Schick, I. \& Tonak, E.

1987a 'Conclusion', pp 365-378 in I. Schick \& E. Tonak (eds.), Turkey in Transition, Oxford, Oxford University Press.

Scott, R.

1965 'Turkish village attitudes towards religious education', The Muslim World, Vol. 55, pp 222-229.

Scott, R.

1971 'Qur'an courses in Turkey', The Muslim World, Vol. 61, pp 239-255.

Shankland, D.

1999 Islam and Society in Turkey, Cambridgeshire, The Eothen Press.

Shaw, S.

1965 'The origins of the Ottoman military reform: The nizam-cedid army of Sultan Selim', Journal of Modern History, Vol. 37, pp 291-306.

Shaw, S.

1969 'The origins of representative government in the Ottoman empire', pp 53-142 in R. Winder (ed.), Near Eastern Round Table, New York, The Free Press.

Shaw, S.

1970 'The central legislative councils in the Ottoman reform movement before 1876', International Journal of Middle East Studies, Vol. 1, pp 51-84.

Shaw, S.

1971 Between Old and New: The Ottoman Empire under Selim III. 1789-1807, Cambridge MA, Harvard University Press.

Shaw, S.

1976 History of the Ottoman Empire and Modern Turkey Vol. I 1280-1808, Cambridge, Cambridge University Press.

Shaw, S. \& Shaw, E.

1977 History of the Ottoman Empire and Modern Turkey Vol. II 1808-1975, Cambridge, Cambridge University Press.

Shorter, F.

1967 'Military expenditures and the allocation of resources', pp 3361 in F. Shorter (ed.), Eour Studies on the Economic Development of Turkey, London, Frank Cass. 
Simmel, G.

1955 Conflict \& The Web of Group Affiliations, (trans. K. H. Wolff), New York, The Free Press.

Simpson, D.

1965 'Development as a process: The Menderes phase in Turkey', The Middle East Journal, Vol. 19, pp 141-151.

Singer, $\mathrm{M}$.

1977 The Economic Advance of Turkey, 1938-1960, Ankara, Verso.

Skocpol, $\mathrm{T}$.

1979 States and Social Revolution, Cambridge, Cambridge University Press.

Skocpol, $\mathrm{T}$.

1985 'Bringing the state back in', pp 3-37 in P. B. Evans et al (ed.), Bringing the State Back In, Cambridge, Cambridge University Press.

Skocpol, $\mathrm{T}$.

1994 Social Revolutions in the Modern World, Cambridge, Cambridge University Press.

Smith, D.

1974 Religion and Political Modernisation, New Haven, Yale University Press.

Smith, E.

1959 Turkey: Origins of the Kemalist Movement and Government of the Grand National Assembly (1919-1923), Washington DC, Judd \& Detweiler.

Smith, W. C.

1957 Islam in Modern History, New York, The New American Library.

Spencer, $\mathrm{H}$.

1969 Principles of Sociology, London, MacMillan

Stein, L.

1923 'The sociology of authority', American Sociological Society, Vol. 18, pp 116-120.

Steinbach, U.

1988 'Turkey-EEC relations: The cultural dimension', pp 13-24 in E. Manisalı (ed.), Turkey's Place in Europe: Economic Political and Cultural Dimensions, Istanbul, Logos. 
Steinbach, U.

1994 'The European Community, the United States, the Middle East and Turkey', pp 103-116 in M. Heper \& A. Evin (eds.), Politics in the Third Turkish Republic, Boulder, Westview Press.

Stern, $S$.

1970 'The constitution of the Islamic city', pp 25-50 in A. Hourani \& S. Stern (eds.), The Islamic City: A Colloquium, Philadelphia, University of Pennsylvania Press.

Stirling, $\mathrm{P}$.

1958 'Religious change in republican Turkey', Middle East Journal, Vol. 12, pp 395-408.

Stirling, $\mathrm{P}$.

1965 Turkish Village, New York, Wiley.

Sugar, P.

1964 'Economic and political modernisation: Turkey', pp 146-175 in R. Ward, \& D. Rustow, (eds.), Political Modernisation in Japan and Turkey, Princeton, Princeton University Press.

Sunar, I.

1974 State and Society in the Politics of Turkey's Development, Ankara, Ankara University Faculty of Political Science Publication No. 377.

Sunar, $\dot{\mathrm{I}}$.

1987 'State and society in the Ottoman empire', pp 63-87 in $\mathrm{H}$. İslamoğlu-İnan (ed.), The Ottoman Empire and the World Economy, Cambridge, Cambridge University Press.

Sunar, I. \& Sayarı, S.

1986 'Democracy in Turkey: Problems and prospects', pp 165-187 in G. O'Donnell \& P. Schmitter (eds.), Transitions From Authoritarian Rule, Baltimore, John Hopkins University Press.

Swanson, G.

1960 The Birth of the gods, Michigan, Ann Arbor.

Szyliowicz, J.

1966 'Political participation and modernisation in Turkey', The Western Political Quarterly, Vol. 14, pp 266-284.

Szyliowicz, J.

1971 'Elite recruitment in Turkey: The role of the Mülkiye', World Politics, Vol. 23, pp 371-397.

Szyliowicz, J 
1973 Education and Modernisation in the Middle East, New York, Cornell University Press.

Szyliowicz, J

1994 'Education and political development', pp 147-159 in M. Heper \& A. Evin (eds.), Politics in the Third Turkish Republic, Boulder, Westview Press.

Szyliowicz, J

2000 'Religion and democracy: The Turkish case', pp 365-394 in Ç. Balım \& C. Imber (eds.), The Balance of Truth: Essays in Honour of Professor Geoffrey Lewis, Istanbul, Isis.

Tapper, R.

1991 Islam in Modern Turkey, London, I. B. Tauris.

Tachau, F.

1964 'Language and politics: Turkish language reform', The Review of Politics, Vol. 26, pp191-204.

Tachau, F.

1973 'Turkish provincial parties', pp 291-316 in K. Karpat (ed.), Social Change and Politics in Turkey: A Structural-Historical Analysis, Leiden, E. J. Brill.

Tachau, F. \& Good, M.

1973 'The anatomy of political and social change: Turkish parties, parliaments and elections', Comparative Politics, Vol. 5, pp 551-573.

Tachau, F. \& Heper, M.

1983 'The state, politics and the military in Turkey', Comparative Politics, Vol. 16, pp 17-33.

Tachau, F.

1984 Turkey: The Politics of Authority, Democracy and Development, New York, Praeger.

Tachau, F.

1984a 'The political culture of Kemalist Turkey', pp 57-77 in J. Landau (ed.), Atatürk and the Modernisation of Turkey, Boulder, Westview Press.

Tachau, F.

1991 'The Republican People's Party, 1945-1980', pp 99-119 in M. Heper \& J. Landau (eds.), Political Parties and Democracy in Turkey, London, I. B. Tauris.

Tezel, Y. 
1975 Turkish economic development, 1923-1950: Policy and achievements', Unpublished $\mathrm{PhD}$ dissertation, Cambridge University.

Thornberg, M., Spry, G. \& Souls, G.

1949 Turkey an Economic Appraisal, New York, Twentieth Century Fund.

Tilly, C.

1978 From Mobilisation to Revolution, New York, Random House.

Tilly, C.

1990 Coercion, Capital and European States AD 990-1990, Oxford, Blackwell.

Timur, $\mathrm{T}$.

1987 'The Ottoman Heritage', pp 3-26 in I. Schick \& E. Tonak (eds.), Turkey in Transition, Oxford, Oxford University Press.

Togan, I.

1991 'Ottoman history by Inner Asian norms', Journal of Peasant Studies, Vol. 18, pp 185-210.

Toprak, B.

1981 Islam and Political Development in Turkey, Leiden, E. J. Brill.

Toprak, B.

1987 'The religious right', pp 218-235 in I. Schick \& E. Tonak (eds.), Turkey in Transition, Oxford, Oxford University Press.

Toprak, B.

1988 'The state, politics and religion in Turkey', pp 119-136 in M. Heper (ed.), State, Democracy and the Military: Turkey in the 1980 s, Berlin, Walter de Gruyter.

Toynbee, A.

1974 'The Ottoman Empire's place in world history', pp 15-33 in K. Karpat (ed.), The Ottoman State and its Place in World History, Leiden, E. J. Brill.

Trimberger, E. K.

1978 Revolution From Above, New Jersey, Transaction Books.

Tünay, $\mathrm{M}$.

1993 'The Turkish New Right's attempt at hegemony', pp 11-30 in A. Eralp, M. Tünay \& B. Yeşilada (eds.), The Political and Socioeconomic Transformation of Turkey, London, Praeger.

Tunaya, $\mathrm{T}$.

1954 'Elections in Turkish history', Middle Eastern Affairs, Vol. 5, pp 116-119. 
Turan, $\dot{\mathrm{I}}$.

1984 'Continuity and change in Turkish bureaucracy', pp 99-125 in J. Landau (ed.), Atatürk and the Modernisation of Turkey, Boulder, Westview Press.

Turan, $\dot{I}$.

1984a 'The evolution of political culture in Turkey', pp 84-112 in A. Evin (ed.), Modern Turkey: Continuity and Change, Opladen, Leske Verlag \& Budrich Gmbh.

Turan, $\dot{\mathrm{I}}$.

1988 'Political parties and the party system in post-1983 Turkey', pp 201-213 in M. Heper (ed.), State, Democracy and the Military: Turkey in the 1980s, Berlin, Walter de Gruyter.

Turan, $\dot{\mathrm{I}}$.

1988a 'Stages of political development in the Turkish republic', pp 58-112 in E. Özbudun (ed.), Perspectives on Democracy in Turkey, Ankara, Turkish Political Science Association.

Turan, $\dot{\mathrm{I}}$.

1994 'Evolution of the electoral process', pp 49-59 in M. Heper \& A. Evin (eds.), Politics in the Third Turkish Republic, Boulder, Westview Press.

Turfan, M.

1987 'Looking after and protecting the republic: The legitimation of the military's authority in Turkey', Paper presented at the British Society for Middle Eastern Studies Annual Conference.

Türsan, $\mathrm{H}$.

1996 'Ersatz democracy: Turkey in the 1990s', pp 215-230 in R. Gillespie (ed.), Mediterranean Politics Vol. II, London, Pinter.

Ulman, A. \& Tachau, F.

1965 'Turkish politics: The attempt to reconcile rapid modernisation with democracy', The Middle East Journal, Vol. 19, pp 153-168.

Ulusan, A.

1980 'Public policy toward agriculture and its redistributive implications', pp 125-167 in E. Özbudun \& A. Ulusan (eds.), The Political Economy of Income Distribution in Turkey, New York, Holmes \& Meier.

United State Helsinki Watch Committee

1983 Human Rights in Turkey's 'Transition to Democracy', New York. 
Van Bruinessen, $M$.

1988 'Between guerrilla war and political murder: The Workers' Party of Kurdistan', Middle East Report, Vol. 18, pp 40-46.

Van Bruinessen, $M$.

1989 'The ethnic identity of Kurds', pp 604-629 in P. Andrews (ed.), Ethnic Groups in the Republic of Turkey, Wiesbaden, Reichert.

Van Bruinessen, $M$.

1991 'Kurdish society, ethnicity, nationalism and refugee problems' pp 33-68 in P. Kreyenbroek \& S. Sperl (eds.), The Kurds: A Contemporary Overview, London, Routledge.

Van Bruinessen, $M$.

1992 Agha, Shaikh and State, London, Zed Books.

Vaner, S.

1987 'The army', (trans. R. Benatar \& I. Schick) pp 236-265 in I. Schick \& E. Tonak (eds.), Turkey in Transition, Oxford, Oxford University Press.

Wallerstein, I.

1974 The Modern World System, New York, Academic Press.

Wallerstein, I., Decdeli, H. \& Kasaba, R.

1987 'The incorporation of the Ottoman empire into the worldeconomy', pp 88-97 in H. İslamoğlu-İnan (ed.), The Ottoman Empire and the World Economy, Cambridge, Cambridge University Press.

Walstead, B.

1977 State Manufacturing Enterprises in a Mixed Economy the Turkish Case, Washington DC, IBRD.

Walter, E.

1964 'Power and violence', American Political Science Review, Vol. 54 , pp 350-60.

Watts, N.

1999 'Allies and enemies: Pro-Kurdish parties in Turkish politics, 1990-1994', International Journal of Middle Eastern Studies, Vol. 31, pp 631-656.

Weber, M.

1946 Essays in Sociology, (trans. by H. H. Gerth and C. Wright Mills), London, Oxford University Press.

Weber, $\mathrm{M}$. 
1947 The Theory of Social and Economic Organisation, (trans. by A. Hanerson and T. Parsons), New York, Oxford University Press.

Weber, $\mathrm{M}$.

1949 The Methodology of the Social Sciences, (trans. by E. Shills and H, Finch), New York, The Free Press.

Weber, $\mathrm{M}$.

1968 Economy and Society, New York, Bedminster Press.

Webster, D.

1939 The Turkey of Ataturk: Social Process in the Turkish Reformation, Philadelphia, The American Academy of political and Social Science.

Webster, D.

1939a 'State control of social change in republican Turkey', American Sociological Review, Vol. 4, pp 247-256.

Wehr, P.

1979 Conflict Regulation, Boulder, Westview Press.

Weiker, W.

1963 'The Aydemir case and Turkey's political dilemma', Middle Eastern Affairs, Vol. 14, pp 258-271.

Weiker, W.

1967 The Turkish Revolution 1960-1961: Aspects of Military Politics, Washington DC, The Brookings Institute.

Weiker, W.

1968 'The Ottoman bureaucracy: Modernisation and reform', Administrative Science Quarterly, Vol. 13, pp 451-470.

Weiker, W.

1972 'Decentralising government in modernising nations: Growth centre potential of Turkish cities', Sage Professional Papers in International Studies, Vol. 1, pp 5-72.

Weiker, W.

1981 The Modernisation of Turkey: From Ataturk to the Present Day, New York, Holmes and Meier.

Weiker, W.

1987 'Constitution-making for Turkey's third republic', pp 33-40 in S. Akural (ed.), Turkic Culture: Continuity and Change, Bloomington, Indiana University Press.

Weir, M. et al 
1988 The Politics of Social Policy in the United States, Princeton, Princeton University Press.

Wickham, C.

1985 'The uniqueness of the East', Journal of Peasant Studies, Vol. 12, pp 165-196.

Wickham, C.

1988 'Historical materialism, historical sociology', New Left Review, No. 171, pp 63-78.

Winter, $M$.

1984 'The modernisation of education in Kemalist Turkey', pp 183194 in J. Landau (ed.), Atatürk and the Modernisation of Turkey, Boulder, Westview Press.

Wolff, P.

1987 Stabilisation Policy and Structural Adjustment in Turkey 1980-1985, Berlin, German Development Institute.

Wrong, D. $\mathrm{H}$.

1979 Power, Oxford, Blackwell.

Yalman, N.

1968 'Intervention and extrication: The officer corps in the Turkish crisis', pp 127-144 in H. Bienen (ed.), The Military Intervenes: Case Studies in Political Development, Russell Sage Foundation, New York.

Yalman, N.

1973 'Some observations on secularism in Islam', Daedalus, Vol. 102, pp 139-169.

Yavuz, $\mathrm{H}$.

1998 'The closure of Refab: The irony of Turkey's "westernisers", Middle East International, February $13^{\text {th }}$, pp 20-21.

Yeğen, $\mathrm{M}$.

1996 'The Turkish state discourse and the exclusion of Kurdish identity', pp 216-229 in S. Kedourie (ed.), Turkey: Identity, Democracy and Politics, London, Frank Cass.

Yenal, $O$.

1967 'Development of the financial system', pp 89-145 in F. Shorter (ed.), Four Studies on the Economic Development of Turkey, London, Frank Cass.

Yerasimos, $\mathrm{S}$.

1987 'The mono-party period', (trans. R. Benatar \& I. Schick) pp 66-100 in I. Schick \& E. Tonak (eds.), Turkey in Transition, New York, Oxford University Press. 
Yeşilada, B.

1987 New political parties and the problems of development in Turkey', New Perspectives on Turkey, No. 1, pp 35-62.

Yeşilada, B.

1988 'Problems of political development in the third Turkish republic', Polity, Vol. 21, pp 345-372.

Zeitlin, $\mathrm{M}$.

1980 'On classes, class conflict and the state: An introductory note', pp 1-6 in M. Zeitlin (ed.), Classes, Class Conflict and the State, Cambridge, MA, Winthrop.

Zürcher, E.

1984 The Unionist Factor: The Role of the Committee of Union and Progress in the Turkish National Movement 1905-1926, Leiden, E. J. Brill. 